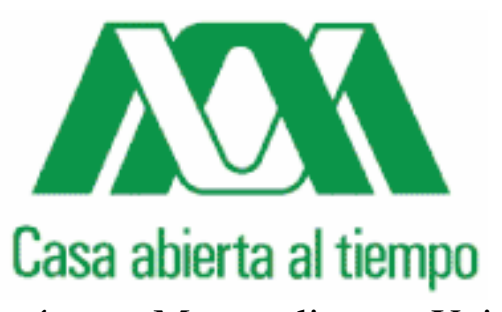

Universidad Autónoma Metropolitana - Unidad Iztapalapa

División del Posgrado en Ciencias Sociales y Humanidades

\title{
Sobre el arte del actor: \\ Texto y representación de \\ El Príncipe Constante \\ de Pedro Calderón de la Barca
}

\author{
TESIS QUE PRESENTA \\ JAIME JORGE PRADO ZAVALA \\ PARA OPTAR POR EL GRADO DE \\ DOCTOR EN HUMANIDADES
}

BAJO LA DIRECCIÓN DE LA

DRA. LILLIAN VON DER WALDE MOHENO

LECTORES SINODALES

Dr. Marcelo SERAFÍn GonZÁlez García

Dr. José Ramón AlCÁntara Mejía

* México, 2012 * 
Para Rocío, Ángel, Gabriel, Susana, Daniel, Pilar, Alondra y Mario. A Jorge Prado, Sr. In memoriam.

*** $*$

A Don Fernando Vargas, noble caballero.

Esta tesis universitaria es la primera en México en el nivel doctoral en tratar directamente los ámbitos del actor, la actuación y la actoralidad. Es el producto de una investigación patrocinada parcialmente por el Consejo Nacional de Ciencia y Tecnología (CONACYT), misma que inició en la Universidad Nacional Autónoma de México (UNAM) y concluye ahora en la Unidad Iztapalapa de la Universidad Autónoma Metropolitana (UAM-I). Fue desarrollada a partir de lecturas, experiencias y reflexiones en torno a la literatura y al arte teatral. Al presentarla hoy acabada, quiero agradecer por toda su fe, apoyo, compañía y cariño brindados a mi tutora Lillian von der Walde Moheno, a mis gentiles sinodales Serafín González y José Ramón Alcántara; a mi compañera Rocío Arista, a mis padres Susana y Jorge, a mis hermanos Pilar y Daniel, a mis hijos Ángel Mario y Gabriel Sebastián, y a mi sobrina Alondra. También a Mario Anaya, Juana Acosta, Nelly Aquino, Odette García de León, Tere Barajas, por los buenos momentos de sincera amistad. Al Laboratorio Libertad: Alejandra Juárez, Lorena Soto, Daniel Millán, Guillermo Rodríguez, Pablo Robles, Juan Antonio Ambriz, Reyna Bravo, Irene Solórzano, Cinthya Castillo, Verónica Bobadilla, Susana Soriano, Julieta Aguirre. A nuestros promotores: Mariana Ozuna, Clara García, Ricardo Orozco, Ezequiel Flores, Oswalth Basurto, Margarita Carpio, Rosa Velasco, Ana María Vázquez, Don Germán Robles, Cinthia Reséndiz, María Stoopen, Óscar Cárdenas, Angélica Ávila, Jacobo Vázquez, Laura Santillán, Héctor Rangel, Christine Huttinger, Natalia Savchenko. A Guadalupe Lucio, quien encabezara el resurgimiento de la Antigua Cárcel de Mujeres de la Ciudad de México como plantel educativo y cultural de vanguardia. A la Academia de Lengua y literatura y al Equipo de Investigaciones Escénicas del IEMS: Carla Constantino, July Vargas, Claudia Piña, Gabriel Silva, José Luis Castillo, Myrna López, Araceli Núñez, María Luisa Cruz, Arturo Trejo, Rosa Becerril, Rocío Osorno, Luis Flores. A los grupos y compañías: Mizpáh (Jesús, Esther, Claudia, Gabriel, Carmen, Alejandra, Cecilia, Leo, Perla, Lety, Ricardo, Mario, Natalia, Pera, Geerda, David, Abril, Bere, Gaby, Enrique, Maga, Mau); Epidauro (Sergio Echeverría Miguel, Lorena Leija, Adriana Lizana, Pilar Padilla); GrotesKa (Raúl, Ivonne, Bety, Max, Violeta, Marisol, Atenea, Ana, Carmen, Irazú, Alejandra, Ernesto, Sergio, Pércival, Xoco, Jackie, Armando, Priscila); Aguaviva (Pedro Antonio Laguna, Carlos Camarillo); Terrazas-Ventura (Azucena, Don Pepe, Antuá, Georgette, Janett), y Drauco (Julieta Hernández, Mayra Mitre); que han hecho crecer mis afectos y saberes en las artes escénicas. A los amables maestros que me han orientado: Erasto Zavala, Helena Beristáin, Ludwik Margules, Irene Artigas, Luz Aurora Pimentel, Federico Patán, Cecilia Tercero, Lauro Zavala, Ricardo García, Armando García, Rodolfo Valencia, José Luis Ibáñez, Aimée Wagner, Gonzalo Blanco, Héctor Téllez, Mario Lage, Rafael Pimentel, Roberto Palomino, José Sanchis, Alexandro César Tamayo y Juan Ramón Góngora. A Jaime Chabaud y Fernando Martínez Monroy por su inolvidable ayuda en España. A mis compañeros del Seminario de Poética del Instituto de Investigaciones Filológicas: Josefina y Daniel. A los actores Margarita Sanz, Laura Almela, Ignacio López Tarso, Mario Oliver y Gerardo Trejoluna, con admiración. Y a ti, heroico lector o lectora. Gracias a todos por todo, con gran aprecio.

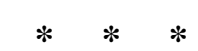




\section{ÍNDICE}

Página

Portada

Dedicatoria y agradecimientos

Contenido

$\begin{array}{ll}\text { Introducción } & 4\end{array}$

Capítulo I: El actor dorado $\quad 20$

Capítulo II: Dramema 38

Capítulo III: El mártir sublime $\quad 64$

Capítulo IV: Éxtasis e iluminación $\quad 83$

$\begin{array}{ll}\text { Capítulo V: Austeridad } & 109\end{array}$

Capítulo VI: El príncipe constante o "La tragedia perdida del Infante Santo Fernando de Portugal”, de don Pedro Calderón de la Barca, tal y como habría sido interpretada en bululú por don Antonio García de Prado en la ermita de Sant Jordi, una legua al norte de Barcelona, la madrugada del 23 de abril de 1629 como penitencia para ingresar a la Cofradía de Actores de Nuestra Señora de la Novena de Madrid

Capítulo VII: Primum vivere, deinde philosophari

Capítulo VIII: Escenoma

CONCLUSIONES

FUENTES DE INFORMACIÓN 


\section{INTRODUCCIÓN}

En el ámbito literario hace falta profundizar en el estudio de la teatralidad en tanto esa dimensión posible que habita en el texto dramático y que se traduce en lo que comúnmente denominamos texto espectacular (discurso escénico). En efecto, ha quedado pendiente leer bien a fondo la efímera literatura que el actor despliega en el escenario. Por lo tanto, un estudio filológico integral de la obra dramática El príncipe constante de Pedro Calderón de la Barca debe extenderse hasta la representación teatral con las herramientas pertinentes para que el análisis rebase las fronteras del papel.

El Teatro es una de las disciplinas humanísticas más problemáticas y más interesantes. Problemática desde el punto de vista académico por la pluralidad de enfoques para su investigación. Por cierto, en universidades como las mexicanas todavía no existen programas consistentes de estudios de posgrado teatral ${ }^{1}$. Pero eso no es todo. Parte del problema es que, dada la naturaleza tan compleja de la práctica teatral, es imposible establecer un modelo unívoco de investigación.

Por otra parte, desde luego que el arte teatral es interesante. Lo es de suyo. Al teatro le incumbe todo lo espectacular para bien y para mal. El teatro hace grande lo pequeño, pero también relativiza las verdades absolutas. Nos permite asomarnos al desarrollo de los actos de heroísmo y de soberbia tanto como al significado oculto de los gestos más humildes y sencillos. Y también hace pensar. Y además cura. El teatro hace pensar al ofrecer un reflejo de los devenires de la existencia humana. Al reflejarnos, nos alimenta con otras posibilidades de ser, despertando nuestra imaginación y nuestra creatividad, nuestro instinto del asombro y nuestra actitud crítica. Todo eso es, como se sabe, pensar. El teatro cura, por otro lado, porque nos permite recuperar la perspectiva de un orden más equilibrado, ideal, invitándonos, sin embargo, a experimentar en una fugaz tormenta la intensidad del caos más temible. Lo hacemos en comunión con otros invitados, otros feligreses, sentados uno junto al otro, hechos uno, para contemplar al Otro de la escena, en un ritual donde podemos proyectarnos: nacer, crecer, vivir, amar, odiar, caer, levantarnos y morir, para luego volver a nacer. Todo como en un milagro que sólo el acto teatral ofrece.

\footnotetext{
${ }^{1}$ En estos momentos se pilotea una maestría en la Universidad Veracruzana. Ojalá que el esfuerzo de esa comunidad académica y artística alcance buena recompensa.
} 
Hoy se sabe que todo el problema y el interés que el teatro implica giran en torno a la relación efímera en un espacio controlado entre el espectador y el ejecutante del texto dramático. El ejecutante propicia la magia, es decir, las voces y los ademanes transformadores del espacio-tiempo cotidiano para volverlo un acontecimiento fuera de lo normal. Sus palabras y silencios, la disposición y despliegue de su cuerpo en el nuevo y volátil éter de la escena, nos cautivan y orientan hacia una experiencia no del todo definible. Es esa participación del ejecutante en la generación del fenómeno teatral una de las intrigas más interesantes en el campo de una de las disciplinas humanísticas más problemáticas. Llamamos al ejecutante teatral: Actor. ¿Cómo lee un actor? ¿Qué relaciones y procedimientos establece para revitalizar, digamos, una obra dramática como El príncipe constante, de Pedro Calderón de la Barca?

\section{Planteamiento del problema}

El texto dramático es una obra literaria que se escribe no sólo para ser leída sino, sobre todo, ejecutada. La lectura del drama lleva por necesidad al ejercicio, imaginario o real, de su representación. El cómo representar en los escenarios de nuestros días una obra de teatro clásica universal sin traicionar su espíritu original (la intentio del autor) es un problema constante y apasionante no resuelto nunca del todo. El periodo del drama barroco del Siglo de Oro español es un claro ejemplo de ello. Traer a la actualidad aquellas historias y aquellos temas enfrenta entre eruditos y público común inagotables discusiones sobre el tiempo, el espacio, los vestuarios, el lenguaje y la actoralidad.

La mayoría de los académicos reclaman un montaje full text, es decir, uno que no haga recortes, ediciones o adaptaciones a los parlamentos originales. No importa si el lenguaje original está lleno de modos y palabras tan en desuso que se escuchen huecas, sin sentido para el público común. Para la academia dura, la interpretación escénica debe ser una especie de "rescate arqueológico", cuyo éxito entre el espectador común bien puede pasar a segundo plano.

En el polo opuesto, el espectador llano espera, desde luego, encontrar divertimento en la puesta en escena. Los valores histórico-culturales del original le son relativos y, por supuesto, agradece con sus aplausos cualquier licencia que se haya tomado la compañía teatral para acomodar la obra a los usos y costumbres contemporáneos. 
Desde Sófocles hasta Chéjov, los llamados "grandes dramas universales" son representados sobre la delgada línea de una prudencia estética que navega entre respetar la versión original con precisión absoluta, o bien, llegar a utilizarla como mero pretexto para un ejercicio de irreverente trasgresión. Hallar el término medio o la innovación que ubique la interpretación del actor equilibrada y/o allende entre la fidelidad histórica y la contemporaneidad es otro problema particular que nos hemos encomendado atender.

\section{Hipótesis preliminar}

El aporte potencial que puede hacer esta investigación necesariamente rebasa los alcances de un estudio literario, pues puede ofrecer nuevas luces acerca de la participación creativa del actor en la generación del sentido escénico (como lector y como ejecutante) del drama. En efecto, partiendo de la dramaturgia como germen original, el drama atraviesa las más

diferentes perspectivas: del lector ingenuo, del crítico, del director de escena, del escenógrafo, para aterrizar en el escenario en las manos y el cuerpo entero del actor, antes del ejercicio activo de contemplación-retroalimentación del espectador. Por eso defendemos que en el actor convergen y desde el actor se proyectan todos los elementos de la representación teatral. Así, en nuestra tesis abordaremos cómo la literatura dramática es interpretada según estrategias muy específicas del actor y cómo esas estrategias, desarrolladas para la puesta en escena, amplían el campo posible de la lectura filológica.

\section{Justificación}

Algunas veces se olvida que fueron los ritos teatrales los que dieron origen a la literatura, y no al revés. Es decir, fue un "actor" quien se volvió el primer escritor, después de bailar durante el ritual propiciatorio de la caza (imitando animales y cazadores), al ponerse a pintar (bajo el mismo esquema imitativo), que entonces era lo mismo que escribir. Luego, esa escritura primigenia habría de ser representada (actuada, cantada, bailada) una y otra vez. Fundamentalmente ello implica, desde entonces, que cada texto (dramático o no) esconde una partitura pendiente de representar, lo que es explícito en el género que denominamos literatura dramática. 
Aquella relación germinal entre literatura y espectáculo se restablece por medio del actor. Si bien hoy la lectura de la obra dramática puede limitarse a la apreciación literaria, todos los lectores imaginan una resolución espectacular con actores ideales (incluso en la lectura de géneros no dramáticos). Por lo tanto, es pertinente que los estudios en humanidades, particularmente en letras, no desatiendan la dimensión espectacular del texto dramático ni a su ejecutante el actor.

Como práctica artística, la manera más directa de estudiar el teatro es haciéndolo. Sin embargo, la fábula del ciempiés nos recuerda cómo se paralizaba a sí mismo al tratar de entender qué hacía para mover cada una de sus numerosas patas, sin lograr a fin de cuentas entenderlas ni moverlas demasiado. Por otro lado, es vocación del arte teatral investigar la naturaleza humana, sus conflictos, sus historias. En realidad, se trata de una cuestión de momentos alternados. Es decir: es imposible actuar y escribir al mismo tiempo, pero nada impide actuar, luego reflexionar y finalmente escribir, secuencialmente.

Escribir para describir el teatro, por lo tanto, tiene que ver con el estudio de la literatura dramática, pero también con el análisis de la experiencia escénica. En ese sentido, vale la pena recordar lo más enriquecedor de esas experiencias. Investigar el arte teatral de esta manera, ponderando desde luego las observaciones con una amplia bibliografía, hace posible una descripción particular de la participación del actor en la creación del hecho escénico.

Desde luego, para nuestro estudio el punto de partida y el fundamento primordial debe estar en un texto dramático bien acreditado en la mejor tradición literaria tanto como en la teatral. Al respecto, creemos que El príncipe constante, de Pedro Calderón de la Barca, sugiere los retos de lectura y de representación espectacular con los niveles analíticos y críticos requeridos para nuestra investigación.

"Si toda la poesía del mundo desapareciera, sería posible reconstruirla sobre la base de $E l$ príncipe constante", escribe Goethe en la carta que envía a Schiller en 1804, junto a un ejemplar manuscrito de la traducción que Schlegel acababa de hacer al alemán. Tanto apasionaba a Goethe esta obra que la leyó, interpretando él mismo todos los papeles, durante una reunión en casa de Johanne Schopenhauer, madre del filósofo. Pronto se decidió a ponerla en escena en Weimar: hizo una adaptación en cinco actos, y eliminó a Brito, el personaje gracioso. [...] Esta obra maestra, escrita por Calderón de la Barca cuando tenía 29 años, hizo que se ganara para siempre el patrocinio de Felipe IV, el rey teatrero. Se dice que El príncipe constante está inspirada en la Crónica de João Alvares sobre la expedición portuguesa contra Tánger, comandada en 1437 por Enrique el 
Navegante. Acabó en desastre. Fernando, hermano de Enrique, fue hecho prisionero: para su liberación, los moros pidieron que se les restituyera Ceuta, cabeza de puente portuguesa en su territorio. No se hizo y el príncipe murió cautivo en Fez. (Vallejo, “El ‘Calderón’ de Grotowski”.)

Se trata de una historia apasionante, con un protagonista entrañable y una dimensión espiritual que reúne, en el mismo drama, el mayor ímpetu artístico de su joven dramaturgo (bien dispuesto a acometer los modelos aristotélicos y lopistas) y las más caras ambiciones morales de su madurez (el auto sacramental). Por la naturaleza misma del argumento, sería imposible omitir el valor religioso de esta obra para optimizar sus cualidades espectaculares, pero tampoco sería deseable arriesgar la potencia dramática por el puro respeto a esa dimensión metafísica, ya muy relativa en nuestros días. Esto significa que un estudio escénico serio de este texto ha de demandar no menos que un fino análisis literario, pero mucho más incluso que una producción espectacular elemental: una interpretación decorosa tanto en lo teórico como en lo práctico.

Después de todo, la idea es encontrar un sendero propio, inédito y propositivo para traer al presente, con fuerza y con fidelidad, un mensaje artístico importante del Siglo de Oro español.

\section{Objetivo}

El actor es el alma del teatro: convierte los conflictos de la historia del hombre en acción viva, encarna las voces del imaginario cultural y crea un mundo posible, un laboratorio ritual, donde podemos contemplarnos y proyectarnos. En los términos más básicos o elementales, se nos dice: "Actuar parece un juego de niños, pero no lo es. Todos creemos que es algo así como fingir la vida. No. Es interpretarla con las herramientas de todo el cuerpo, incluido el cerebro" (Braulio Peralta, "De la naturaleza del histrión”, 14).

En esta investigación se pretenden recuperar diversas lecturas, reflexiones, propuestas y experiencias en torno a la literatura dramática en general y sobre su relación con el actor en particular, con el objetivo de desarrollar una descripción precisa de la participación del actor en una evolución fiel del texto dramático al discurso espectacular. Para ello, se intentará proponer un enfoque actoral original a la lectura del drama, producto del testimonio de un actor sobre la escena, y como director, dramaturgo, espectador de teatro y académico, con el fin de integrar un todo que dé cuenta de la 
multiplicidad de procesos creativos y críticos que acompañan la lectura teatral, analizando en especial la participación del actor en la creación del discurso escénico. El hilo conector para poner en diálogo estos temas es la construcción de una interpretación escénica integral de El príncipe constante, de Pedro Calderón de la Barca.

La pertinencia de desarrollar una investigación teórico-práctica parte del interés por reconciliar las dos facetas primordiales del hecho artístico: la creación y la contemplación. De acuerdo con José Ramón Alcántara Mejía:

es necesario tomar en cuenta que la constante crítica de los grandes teatrólogos de todos los tiempos, desde Lope de Vega en su Arte nuevo de hacer comedias y Shakespeare en Hamlet, pasando por Victor Hugo y su Prefacio a Crownwell hasta llegar, por supuesto, a Artaud, Grotowski y otros grandes teatristas contemporáneos no ha sido contra la teoría, sino contra la pretensión de que se pueda 'teorizar' fuera del hecho teatral ("Redescubriendo la teoría", 85).

\section{Antecedentes}

Como breve antecedente de una puesta en escena calderoniana con aspiraciones de relativa fidelidad podemos recordar en México La vida es sueño, dirigida por José Luis Ibáñez en 1997. ${ }^{2}$ Nos consta, porque asistimos a varios ensayos y funciones en la UNAM (advierto que nunca como actor), que su esfuerzo con los actores consistió en aprehender juntos un conocimiento profundo del sentido del texto y, desde ahí, convertirlo en intenciones verbales, gestos corporales, tareas escénicas sutiles y complejas, etc. Ibáñez confirmó así la conocida tesis de Lope de Vega de que si el actor comprendía con claridad al poeta, entonces el espectador también, como Juan Manuel Rozas nos lo recuerda:

El desbordamiento de las pasiones, el gusto por experimentarlas -que se observa en los noticieros de la época- nos va a situar en el centro de nuestro problema. La pasión la inventa el dramaturgo, pero debe sentirla -saber sentirla realmente- para poder expresarla; pasa luego al actor y de nuevo éste debe sentirla realmente, para comunicarla al espectador, en quien realmente revive. Esto lo dice literalmente Lope en varios textos. Así, en Lo fingido verdadero, y obsérvese cómo hace equivalente el proceso indicado en el dramaturgo y en el actor:

El imitar es ser representante;

pero como el poeta no es posible

\footnotetext{
${ }^{2}$ Lillian von der Walde nos recuerda que hubo trastrueque de cuadros, cambio de la prisión de Segismundo de torre a pozo e interpretación cantinflesca de algún personaje, entre otras licencias de la dirección.
} 
que escriba con afecto y con blandura

sentimientos de amor si no le tiene,

así el representante, si no siente

las pasiones de amor, es imposible

que pueda, gran señor, representarlas;

una ausencia, unos celos, un agravio,

un desdén riguroso y otras cosas

que son de amor tiernísimos efectos,

haralos, si los siente, tiernamente;

mas no los sabrá hacer si no los siente.

(Juan Manuel Rozas, Sobre la técnica del actor barroco.)

La cita de Lope es elocuente por cuanto se refiere a la necesidad de empatía del actor (el recitante) hacia el personaje. La apuesta full text de Ibáñez fue además enmarcada en una ambientación mística más allá de una mera ubicación espacio-temporal, mediante decorados surrealistas de Vicente Rojo inspirados en el arte visual de Leonora Carrington. Lo más interesante de tal propuesta modernista fue, consciente o inconscientemente, que los poetas dramáticos del siglo XVII, es decir, no los actores ni los empresarios (llamados estos últimos autores de comedias), sino los dramaturgos, proponían lo mismo: apoyarse un poco en la iconografía disponible, en las artes visuales. ${ }^{3}$

Este detalle de la iconicidad se repite en un montaje bastante memorable en el siglo XX de otra obra de Calderón: El príncipe constante, dirigido por Jerzy Grotowski en Wroclaw, Polonia, en 1968. Se trata de una de las pocas trasgresiones que han llamado seriamente la atención de los académicos. Esto se debió, sorprendentemente, a la austeridad de los elementos de producción del espectáculo y, también sorprendentemente, al tratamiento dramatúrgico, donde Calderón aparecía en la trascripción romántica de Julius Slowacki. El carácter iconográfico de la puesta en escena estuvo dado por claras alusiones a la Anatomía del Doctor Tulp de Rembrandt, a los grabados de Doré para La divina comedia de Dante, a la pintura hagiográfica de El Greco y a la escultura sacra El Cristo triste,

\footnotetext{
${ }^{3}$ Así lo observa Evangelina Rodríguez en "Registros y modos de representación en el actor barroco", en José María Diez Borque (ed.) 1989. Actor y técnica de representación del teatro clásico español. 43 y 44. Otras herramientas usadas en la metodología actoral de entonces fueron las teorías de los humores y de las pasiones, de las que cabría hablar en otra investigación.
} 
popular en Polonia. ${ }^{4}$ Más sorpresa causó aún el trabajo del elenco, encabezado por Ryszard Cieslak como el Príncipe. El alto grado de concentración, la precisión coreográfica de las tareas escénicas, el entrenamiento del cuerpo y de la voz, el control absoluto de las emociones y la mística del grupo del Teatr-Laboratorium cautivaron a la crítica y, más profundamente, a los creadores escénicos asistentes entre el público que atestiguó cada función en Wroclaw, primero, y en distintas ciudades del mundo después, incluida México. A propósito de El príncipe constante, Grotowski declaró:

El actor debe tratar al personaje como una especie de desafío en el que su respuesta ha de comprometer toda su capacidad (Entrevistado por Margo Glantz para el suplemento "La cultura en México" de la revista Siempre! en octubre de 1968, y citado en Hacia un teatro pobre 224).

Es así como uno de los grandes revolucionarios del teatro contemporáneo reconocía no sólo el valor filológico y lingüístico del texto interpretado, sino también su potencial artístico y espiritual, tal y como lo demostró escénicamente. Entonces parece que todavía hay caminos estéticos o, mejor dicho, existen nuevos caminos que pueden acercarse a los ideales originales de comunión íntima, sagrada, del teatro religioso calderoniano. Particularmente interesante es de notar que tal acercamiento pueda ser logrado a partir de una lectura comprometida del actor.

\section{Metodología}

Para comenzar a estudiar el teatro no sólo como arte, sino también como ciencia (la ciencia teatral o -simplemente- teatrología), debemos hacernos de un concepto autorizado de ciencia. Ruy Pérez Tamayo, como científico reconocido y miembro además de la Academia Mexicana de la Lengua, opina: "Conviene caracterizar a la ciencia como una actividad creativa humana cuyo objetivo es la comprensión de la naturaleza y cuyo producto es el conocimiento." (Acerca de Minerva. 65.)

Como vemos, la ciencia se asemeja al arte en tanto que ambas son actividades creativas. Ahora bien, para comprender la naturaleza del teatro y producir acerca de él

\footnotetext{
${ }^{4}$ Grotowski, Hacia un teatro pobre.
} 
algún conocimiento, hay quien toma la perspectiva científica avant la lettre, es decir, en la concepción más dura de una ciencia experimental:

La práctica teatrológica debe cumplir con el requisito fundamental de producir experimentos repetibles, observables, creando así las condiciones necesarias de validación o de invalidación, según las condiciones que prevalecen en el desarrollo de la experiencia (Luis Thenón. 2002. "La formación del actor-investigador" 22).

En lo que no cabe duda, es en la necesidad de hacer del estudio del objeto-teatro no solamente una materia teórica, sino también práctica, mediante una perspectiva de ciencia experimental. El estudio del teatro tiene la particularidad de ubicarse en el cruce de dos ámbitos diferenciados: la literatura y el fenómeno escénico. Quizá por ello:

La investigación teatral hasta hace dos décadas se asociaba casi exclusivamente con la interpretación de la literatura dramática a través de las teorías literarias y el análisis crítico acorde a los conceptos de la estética o a los juicios ideológicos que le otorgaban valor (Elka Fediuk. 2002. "Investigar la formación teatral superior" 109).

En 1997, Ricardo García Arteaga y Alejandro Ortiz Bullé Goyri señalaban:

Como ocurre en otras áreas del conocimiento, se hace necesario determinar los campos y las líneas de investigación en el teatro. Los diferentes campos que por el momento parecen ser los dominantes son: investigación teórica (conocimiento del teatro, sus lenguajes y sus vínculos con otras disciplinas, sin necesidad inmediata de corroboración práctica), investigación histórica (hechos teatrales del pasado), investigación aplicada (problemática de la puesta en escena) e investigación experimental (combina la creación artística con el método científico). (Varios, Métodos y técnicas de investigación teatral. 42 y 68-75).

Reconociendo que "uno de los campos que puede desarrollarse [...] es el de la investigación teatral, por el hecho de ser una valiosa fuente para todo lo relacionado con las artes escénicas" (Métodos y técnicas de investigación teatral, 9), pero que "una de las carencias [...] es la falta de un posgrado" (ibid., 10), se han procurado reiterados intentos para alentar la indagación y generación del conocimiento teatral con estándares internacionales: programas experimentales de maestría (en la UNAM y en la UV); un Seminario de Investigaciones Etnodramáticas (creado por Óscar Zorrilla, Nicolás Núñez y Gabriel Weisz, con la participación de Jerzy Grotowski, en 1981); un Seminario para la Investigación de las Artes Escénicas (SIAE, coordinado por Carlos Solórzano y Gabriel 
Weisz hasta 1997), y un Seminario de Estudios Teatrales (coordinado por Carmen Leñero hasta 2007); todos éstos en la UNAM. Por su parte, la UAM ha impulsado, junto con Edgar Cevallos, el proyecto editorial Escenología, mismo que desde los años 80 del siglo pasado difunde conocimiento teatral altamente especializado; admite investigaciones relacionadas con el hecho escénico y mantiene colaboraciones académicas con instituciones como el Centro de Investigación y Documentación Teatral Rodolfo Usigli (CITRU). Actualmente, la UAM también coadyuva en algunos proyectos de la editorial teatral Paso de gato y de su director, Jaime Chabaud Magnus.

Actualmente, además del análisis literario, se cuenta con múltiples herramientas teóricas y teórico-prácticas que atienden un número creciente de áreas de estudio: teorías dramáticas y escénicas, historia, psicoanálisis, lingüística, heurística, hermenéutica, semántica, semiótica-semiología del teatro, recepción teatral, etnología y antropología teatral, etc. Para englobarlas a todas, suele hablarse simplemente de teatrología: "El uso de la palabra 'teatrología' se ha caracterizado por la asociación espontánea de este término con la investigación teórica del teatro" (Thenón 11). Se implica con bastante pertinencia la amplitud y alcance del concepto:

...un sector de la investigación, cuyo campo de estudio es el fenómeno teatral en su integridad de obra escrita y de obra representada, pero cuya actividad no se limita exclusivamente al campo de la investigación teórica, sino incluye también al de la práctica teatral y la reflexión teórica que emerge del estudio sistemático y metodológico de la actividad escénica (Thenón 11).

Patrice Pavis aclara: “Este término reciente y limitado al empleo ‘erudito’, si no científico, corresponde mejor al término alemán theaterwissenschaft. Lo determinante en él, más que su exigencia científica, es la totalidad y autonomía de la disciplina crítica encargada de examinar las manifestaciones teatrales" (1980, Diccionario de teatro 496). Para fines prácticos, en este trabajo mantendremos el término en castellano y también el enfoque teórico-práctico sobre la investigación teatral vista como investigación experimental.

Para acercarnos a estos propósitos, proponemos particularizar la investigación en la obra de Pedro Calderón de la Barca El príncipe constante, un texto de asunto históricoreligioso con grandes exigencias de caracterización con respecto al protagonista. Para su representación, además de un análisis literario integral del drama, el actor debe hacer una 
lectura puntual de los objetivos más profundos del personaje, a partir de los cuales se justifiquen las acciones dramáticas y se definan las tareas escénicas que el espectador aprecia como la "actuación”. A este respecto, una de las vertientes teatrológicas más discutidas recientemente para perfilar las distintas fuerzas que componen la maquinaria del texto dramático es la semiología.

Creemos que con una metodología semiológica de lectura como punto de partida podemos encontrar un enfoque actoral particular que analice la literatura dramática en su dimensión de partitura escénica.

Toda reflexión sobre el texto teatral se encontrará obligatoriamente con la problemática de la representación; un estudio del texto sólo puede constituir el prolegómeno, el punto de partida obligado, pero no suficiente, de esa práctica totalizadora que es la práctica del teatro concreto (Anne Ubersfeld, Semiótica teatral: 10).

La efectividad de nuestro procedimiento, consideramos, requerirá su confirmación por medio de un espectáculo real. El espectáculo permitirá determinar si la lectura semiológica del actor aclara y/o actualiza el discurso ideológico-cultural del texto dramático para el público, o bien, hasta qué punto lo limita. Tal será, en esencia, la ruta crítica para nuestro estudio literario.

\section{Estado de la cuestión o del arte y marco teórico-conceptual}

El marco teórico-conceptual de la dramaturgia barroca partirá de un reconocimiento autorizado de las condiciones originales de trabajo de los creadores escénicos (poeta, autor de comedias, actor) estudiadas por Díez Borque, Josef Oehrlein y Evangelina Rodríguez, entre algunos otros; reconocimiento que dejará un horizonte claro para leer El príncipe constante en un análisis genérico y semiológico actancial basado en Algirdas Greimas y Anne Ubersfeld. Luego, el discernir en torno a la evolución del protagonista (basándonos en Lope de Vega, George Steiner, Ruiz Ramón y Ariel Rivera) facilitará comenzar una cuidadosa toma de decisiones sobre la orientación de la lectura. Una vez precisado el sentido original y profundo del texto con esos apoyos, la lectura atenta de las acotaciones literales y subtextuales facilitará el diseño de una concepción escénica que considere la estética barroca original, su potencial artístico contemporáneo, el discurso gestual-vocal y el psicológico-emocional, de modo que se pueda proyectar un trabajo actoral integral. 
Sobre esta base conceptual de puesta en escena, la articulación de una partitura actoral particular para un personaje deberá considerar, junto a una agenda puntual de ensayos y una línea de acciones-pensamientos-emociones, el training necesario que capacite al ejecutante para su interpretación. La experiencia documentada propone referirse a los entrenamientos stanislavskianos y grotowskianos, aunque no omitimos la posibilidad contingente de matizar durante el eventual proceso de montaje sobre hallazgos propios. De ahí que consideremos imprescindible llevar la obra a escena en forma experimental, pues sólo así tendremos el feedback que confirme o refute nuestras suposiciones literarias y estéticas, así como los indicadores finales que nos permitirán emitir una conclusión.

Específicamente sobre nuestro texto-objeto de estudio, no es poco lo que se ha discutido. Robert Lauer ${ }^{5}$ tiene elaborada una bibliografía muy específica, aunque no del todo actualizada, sobre El príncipe constante.

En la bibliografía de Lauer la mayoría de las aportaciones versan sobre el contenido (argumento, contexto, tema, personajes, símbolos, imágenes, política, filosofía y religión) y la forma del texto dramático (estructura, figuras poéticas, cronotopías). Más en concreto, mientras García Gómez, Stroud y Whitby analizan la trama, Halkhoree y Varey exploran el espacio carcelario, Alexander Parker la cosmovisión cristiana, Antonio Sánchez el juego virgiliano del espíritu de Fernando guiando a los portugueses, y Yun Shao la importancia de la iconografía en las didascalias dramáticas barrocas. Varios autores hallan un interés particular en el sentido de los sonetos de Fénix y Fernando: Pablo Cabañas, Terence O’Reilly, Germán Orduna y Elias Rivers. ${ }^{6}$

Casi todos los trabajos que hablan directamente sobre la representación de la obra hacen referencia a la puesta en escena dirigida por Jerzy Grotowski en los años 60 del pasado siglo XX: Stefan Brecht, Donald Larson, Charles Ludlam, Serge Ouaknine, Jean Jacquot, salvo los de David Ladra y Jack Sage. A continuación comentamos otros títulos que nos parecieron sugerentes para reflexionar sobre una hipotética reposición escénica.

Desde una perspectiva psicologista, Enrica Cancelliere hace un estudio comparativo entre Segismundo, de La vida es sueño, y Fernando, el protagonista de El príncipe

\footnotetext{
5 http://faculty staff.ou.edu/L/A-Robert.R.Lauer_1/BIBLIOGRAFIAINFOASISTIDA ， consultada en septiembre de 2009.

${ }^{6}$ Lillian von der Walde nos anota no olvidar que la forma poética incide, ciertamente, en la representación. Redondillas, casi siempre, conducen a un diálogo más coloquial, sin tantos tintes emocionales; mientras que el soneto es especial: en éste se carga, por lo general, un elevado sentido emocional.
} 
constante, y además -en otra disertación- analiza el thánatos estratégico del segundo. Héctor Hernández Nieto hace el psicoanálisis edípico de la obra. Susan Fischer estudia la clarividencia y el martirio como tópicos psicológicos, y Elena Gascón indaga sobre la voluntad y el deseo.

Dado que para la definición del género dramático es fundamental la trayectoria del personaje, resulta de interés que varios estudiosos lean en esta comedia nueva una tragedia. Recordemos que El príncipe constante está señalada como comedia (drama de final feliz) por su propio autor, como lo recuerda Carlos Ortigoza. Hay, en efecto, además de un personaje gracioso (como en toda "comedia nueva"), un final donde, tras todas las peripecias, los viciosos son sentenciados y los virtuosos recompensados. En contraste, Audrey Lumsden, Jesús Maestro, James Parr, Arnold Reichenberger, Matthew Stroud y Karen Vincent plantean la lectura del texto como la tragedia de un mártir de la Contrarreforma. Goethe mismo prefirió un enfoque trágico más "puro" hasta el punto de eliminar al personaje gracioso en su personal adaptación, estudiada en manuscrito por Henry Sullivan.

Sobre el desarrollo y función dramática de los personajes hay análisis tan concretos como el de Alberto Porqueras sobre el moro Muley, o el de William Whitby sobre Fénix, así como el más amplio sobre la acción y los personajes de Robert Sloane, o uno sobre el adyuvante femenino de Sharon Voros, mismo que ya nos sugiere un análisis semiológico.

Fuera ya de la bibliografía de Robert Lauer encontramos otros nichos-posiciones que se adelantan como precursores a la discusión que nos interesa. Estas fuentes argumentan en torno al contexto de producción y acerca de la intersección entre literatura y teatro.

En el panorama teórico conceptual del contexto literario, teatral y cultural del Barroco español consideramos a Alonso López Pinciano, a Sebastián de Covarrubias Orozco, a Lope de Vega, además del mismo Calderón de la Barca, así como los estudios que sobre el teatro en ese periodo hacen Oehrlein, Díez Borque, Rodríguez Cuadros, entre otros. Desde luego, Aristóteles y Séneca fueron tomados en cuenta como autores de cabecera en el Siglo de Oro. Además no dejamos de considerar la pintura y la arquitectura como referentes culturales importantes para comprender el Barroco. También hicimos un análisis comparativo entre el Barroco y el estilo estético contemporáneo del Minimalismo 
con el fin de orientar las condiciones objetivas para un montaje contemporáneo que no perdiera fidelidad al contexto original.

Con respecto al ámbito liminal entre la literatura, la representación y el actor hay que mencionar los estudios semiológicos de Anne Ubersfeld y Fernando de Toro; los antropológicos de Eugenio Barba y Nicola Savarese; las técnicas de actuación sistematizadas por Constantin Stanislavski y Jerzy Grotowsky; las observaciones sobre autorreferencialidad actoral de William Worthen; la teoría de la recepción, y el método rizomático de Deleuze y Guattari. Todas estas teorías modernas y contemporáneas complementarán y enriquecerán el campo del estudio del Teatro Áureo.

El panorama que nos ofrecen estas fuentes nos permite atisbar el ámbito donde nuestra aportación puede ser pertinente. Por otro lado, la relativa escasez de comentarios sobre otras puestas en escena (casi todas las referencias performativas acuden a Grotowski) justifica un nicho sobre el cual apoyar un nuevo estudio por completo original.

Ahora bien, sobre el campo específico del actor barroco, una de las bibliografías más pertinentes es la elaborada por Evangelina Rodríguez Cuadros. Entre la teoría y crítica del Barroco que toca la figura del actor, Rodríguez Cuadros revisa desde tratados morales como Bienes del honesto trabajo, y daños de la ociosidad, en ocho discursos, de Pedro de Guzmán (Madrid, 1613) y Primera parte de las excelencias de la virtud de la castidad, de José de Jesús María (Alcalá, 1601), que sancionan el oficio vulgar del actor; cartas oficiales como Memorial impreso al rey don Felipe II, para que levante la suspensión en las representaciones de comedias, de Casiano Pellicer (1598), que le defienden; intentos descriptivos como el Discurso theológico sobre los teatros y comedias de este siglo, de Ignacio Camargo (Salamanca, 1689), el Tesoro de la lengua castellana, de Covarruvias (1611) y el Diccionario de autoridades (1726-1739); hasta el Tratado de las pasiones, de René Descartes (1649). La mayoría de estas fuentes se refieren a la profesión del actor, así como a usos, costumbres y juicios morales. Pocos, como veremos a lo largo de nuestra propia investigación, explican las estrategias del actor para propiciar el tránsito textoespectáculo.

Otros autores más recientes a los que haremos referencia nos darán más luz tanto para hablar del actor y el arte teatral como de la literatura dramática y su particular genealogía, así como de El príncipe constante. Algunos son: William Worthen, Roland Barthes y 
Michel Foucault, acerca de la condición actual de la figura del autor; Gilles Deleuze, Félix Guattari, Paul De Man, Michael Bajtin, Gabriel Weisz Carrington sobre la investigación humanística contemporánea; y abundantes dramaturgos, directores y actores teatrales para explicar la función del actor y la pertinencia de la actoralidad teatral como objeto de estudio.

\section{Capitulario}

Para nuestro estudio proponemos el siguiente itinerario:

0. Introducción. Planteamiento del problema, hipótesis, antecedentes, objetivos, justificación, marco teórico-conceptual, metodología.

1. El actor dorado: Los representantes en el siglo de Calderón. Contexto cultural de producción. El actor frente a la literatura dramática en el Barroco español.

2. Dramema: Análisis semiológico del texto dramático. Disección estructural que determine las funciones semánticas superiores del/los personajes principales.

3. El mártir sublime: Análisis genealógico. Estudio particular del argumento, tono, acciones internas y/o psicológicas y acciones externas o físicas del protagonista, es decir, de la trayectoria del personaje en el texto dramático, con miras a una caracterización genealógica del texto espectacular (o partitura escénica).

4. Éxtasis e Iluminación: Estética teatral del Barroco. Lógica visual de la creación literaria y actoral en el Siglo de Oro Español.

5. Austeridad: El minimalismo teatral neobarroco. Fundamentos para una estética escénica neobarroca (consecuente con la actualidad y leal con el Siglo de Oro Español).

6. El príncipe constante o "La tragedia perdida del Infante Santo Fernando de Portugal", de don Pedro Calderón de la Barca, tal y como habría sido interpretada en bululú por don Antonio García de Prado en la ermita de Sant Jordi, una legua al norte de Barcelona, la madrugada del 23 de abril de 1629 como penitencia para ingresar a la Cofradía de Actores de Nuestra Señora de la Novena de Madrid. Concepción de puesta en escena. Cuaderno de dirección. 
Adaptación dramatúrgica. Conversión del texto dramático original en texto espectacular o partitura escénica (versión libre de El príncipe constante).

7. Primum vivere, deinde philosophari. Ensayos, representación, recepción. Representación escénica. Estudio actoral específico de don Fernando, protagonista de El príncipe constante. Conversión de la partitura escénica en discurso espectacular (ejercicio representacional). Análisis de la puesta en escena. Registro fotográfico y en video. Análisis comparativo de la recepción del ejercicio representacional. Evaluación global de la experiencia actoral.

8. Escenoma. Apuntes para una micropoética de la lectura actoral. Descripción analítica y crítica de los procesos de lectura, interpretación y creación artística del actor en la configuración de un discurso espectacular.

9. Conclusiones. Recapitulación y ponderación de la tesis. Consideraciones finales.

\section{Fuentes de información.}

En resumen, estudiaremos cómo una particular perspectiva teatrológica del actor condiciona modos prácticos específicos de lectura sobre el texto dramático y orienta su resolución espectacular, utilizando El príncipe constante como caso práctico. Lo que ofrecemos, por lo tanto, es un ejercicio crítico riguroso fundado en un diálogo propiciatorio $^{7}$ que apunte hacia la acotación de un pequeño modelo que explique a la literatura dramática y al teatro desde la visión actoral.

\footnotetext{
${ }^{7}$ Usamos diálogo desde luego en el sentido implícito de un intercambio enriquecedor entre distintos ámbitos temáticos, disciplinas y formas teórico-conceptuales, metodologías, hipótesis y experiencias que, entre otros autores, encuentra su paradigma ejemplar en Mijail Bajtín, cuya hermenéutica dialógica "permite inscribir la pluralidad de distintas voces sin reconciliar las mismas en una sola única identidad monolítica sino, al contrario, valora las especificidades de sus funciones respectivas" (Malcuzynski 1996, 38).
} 


\title{
CAPÍtulo I: El ACTOR DORADo
}

\section{Los representantes en el siglo de Calderón}

\begin{abstract}
Me parece que hace tiempo el teatro se ha constituido en el único espacio posible para que el hombre actual sea capaz de integrar en su experiencia a los clásicos del Siglo de Oro. (Evangelina Rodríguez Cuadros, "Registros y modos de representación en el actor barroco”, en Díez Borque 1989: 52.)
\end{abstract}

El Siglo de Oro español suele subdividirse, para su mejor estudio, hasta en tres ciclos: prelopista (que podría abarcar desde la precursora Comedia o tragicomedia de Calixto y Melibea o La Celestina de Fernando de Rojas, hasta Los Pasos de Lope de Rueda), lopista (que cubre toda la producción del autor de El arte nuevo de hacer comedias, a la mayoría de sus epígonos y a Cervantes) y el ciclo de Calderón. ${ }^{8}$ José Luis Sirera Turó es uno de los estudiosos que apoya esta división; básicamente es a partir de su trabajo El teatro en el siglo XVII: El ciclo de Calderón que desarrollamos la primera parte del presente capítulo (a menos que una referencia indique otra fuente), en el que hablaremos sobre el dramaturgo y la figura del actor en su contexto cultural.

Pedro Calderón de la Barca nace el 17 de enero de 1600 en Madrid. Dada su longeva existencia (muere a los 81 años), le corresponderá ver fenecer a casi todos sus competidores y, gracias a sus méritos profesionales, se convertirá en el último gran autor dramático de un imperio en donde no se ponía el sol. Una de sus primeras obras la escribe cuando sólo tiene trece años: El carro del cielo.

Calderón sobrevive a varios monarcas: Felipe III, Felipe IV (el rey teatrero), el ministerio del Conde-Duque de Olivares y las diligencias de Mariana y Juan José de Austria (regente y privado, respectivamente, de Carlos II). También ve pasar muchas crisis económicas (quiebras del Estado), religiosas (la Reforma), sanitarias (pestes) y bélicas. Es testigo de las guerras con Inglaterra (hasta 1604) y los Países Bajos (hasta 1609), la de los

\footnotetext{
${ }^{8}$ Lo más habitual es encontrar una división del Siglo de Oro en dos ciclos marcados por un relevo entre Lope de Vega (1er ciclo) y Calderón ( $2^{\circ}$ ciclo) alrededor de 1635 (fallecimiento de Lope). Al ciclo de Lope pertenecen él, Guillén de Castro, Mira de Amescua, Vélez de Guevara, el indiano Ruiz de Alarcón y Tirso de Molina. En el de Calderón se incluyen él, Rojas Zorrilla, Agustín Moreto y la mexicana Juana de Asbaje. Ver Oehrlein: 8; Ruiz Ramón (Historia del teatro español, Madrid: 1979); Bobes Naves (Semiótica de la escena, Madrid: 2001. 416) y Alborg (Historia de la literatura española, Madrid: 1977.)
} 
Treinta Años, algunas muy específicas contra Francia, además de las sublevaciones de Cataluña y Portugal, y levantamientos en Andalucía, Aragón, Navarra y Valencia.

Después de obtener el título de bachiller, Calderón se hace soldado y combate en Flandes e Italia. Es en esta última donde conoció, muy probablemente, todas las posibilidades técnicas de la escenografía teatral.

En general, la España de los Austrias intentará todo este tiempo mantener una concepción política basada en la autoridad y hegemonía del Papado y el Imperio, es decir, el concepto de una Europa vertical, frente a otros estados que defienden una concepción política soberana, o sea, una Europa horizontal.

El teatro español refleja esta cosmovisión a través de una fuerte tendencia ideológica, donde los estamentos de Dios, el Rey y el honor determinan una estética del decoro, misma que impregna, como estaremos viendo, todos los ámbitos de producción: la dramaturgia, el escenario, la actoralidad. "No sólo se examinaban los textos, sino que los censores también juzgaban desde el criterio que se había formado en los ensayos a las representaciones acerca de la pieza." (Oehrlein: 29). Esto significa que para los censores era tan importante la pieza literaria como su interpretación espectacular. Afortunadamente, y es importante aclararlo, esta influencia -más moral que artística- no condiciona totalmente las obras teatrales.

Por su parte, Félix Lope de Vega condiciona la forma de entender y hacer el teatro de todo el siglo a partir de su Arte nuevo (1609). Para Macgowan y Melnitz, Lope "fue el inventor más grande del Siglo de Oro español, que le tocó iniciar. Fue quien dio forma final a la comedia y le proporcionó además distinción” (115). En 1622 Lope aplaude el tercer lugar alcanzado por Calderón (iniciado ya en 1620 como poeta de certamen) en el concurso de poesía por la canonización de San Isidro:

\section{A Don Pedro Calderón admiran en competencia cuantos en la edad antigua celebran Roma y Atenas.}

(Lope de Vega, citado por Rodríguez Cuadros en Un discreto a voces.)

El joven poeta, sin embargo, con el triunfo de su primera comedia Amor, honor y poder (de 1623) prefiere mejor hacerse dramaturgo. Esta decisión marcará sus creaciones con la 
ineludible intentio que acompaña a todo drama: la exigencia de ser no solamente leídas, sino sobre todo representadas. ${ }^{9}$

Calderón alcanza pronto su propio prestigio, con obras que desde una etapa primeriza abarcan todos los géneros y se dirigen tanto a los corrales como a Palacio: La dama duende, En esta vida, todo es verdad y todo es mentira, El purgatorio de San Patricio, El sitio de Breda, El astrólogo fingido.

En 1629 el Rey ordena iniciar la construcción del Palacio del Buen Retiro en el que, aunque al principio no hubo ningún espacio concebido especialmente para representaciones teatrales, se utilizó un teatro portátil construido por Cosimo Lotti.

Ese mismo año Calderón escribe su primera obra maestra: El Príncipe Constante. La obra relata el heroico comportamiento del príncipe portugués Fernando, cautivo de los moros, que prefiere la muerte antes que entregar Ceuta. Calderón aprovecha la anécdota del héroe nacional lusitano en los momentos en que Portugal forma parte del Imperio Español. Ya primero Lope de Vega había hecho su propia versión. Años después, Portugal se independizará de España y entonces elogiar al Infante Santo, ahora enemigo, será complicado. ${ }^{10}$ La diégesis fundamental, sin embargo, se sostiene. Es la trágica historia de cómo el infante don Fernando, príncipe de Portugal y maestre de la orden de caballería de Avis, intenta arrebatar el puerto de Tánger a los moros, con la ayuda de su hermano Enrique el Navegante; pero cayendo preso -y al no aceptar su rescate con la entrega de la estratégica ciudad de Ceuta- es maltratado hasta morir, defendiendo con su vida la fe cristiana.

En 1632 escribe La devoción de la Cruz, mientras Galileo Galilei revoluciona la ciencia (al confirmar la teoría heliocéntrica de Copérnico) y Londres presume poseer 17 teatros.

A partir de la muerte de Lope de Vega (1635) vendrá la consolidación dramatúrgica de Calderón: El mayor encanto amor (1635), La vida es sueño (1635), El médico de su honra (1635) ${ }^{11}$, El mágico prodigioso (1637), El alcalde de Zalamea (1642), etc. Mientras,

\footnotetext{
${ }^{9}$ De ahí que nuestro estudio busque abarcar la puesta en escena como estrategia de lectura integral, recurriendo para ello a la perspectiva del actor como lector especializado, ejecutante del texto dramático.

${ }^{10}$ Entre el manuscrito de 1629 y la edición princeps de 1636 hay notables diferencias. Otros cambios aparecen en 1640. Hablaremos de ello conforme nos vaya resultando pertinente.

${ }^{11}$ Nótese lo vasto de la producción calderoniana tan solo en ese año.
} 
en el mundo, pintan Rembrandt y Van Dick, se funda la Academia Francesa, Corneille escribe Le Cid y Descartes su Discurso del método.

Desde 1651 deja de escribir para los corrales (hay además desgracias familiares y nuevas políticas culturales), y refugiado en el sacerdocio produce (para la Corte y la fiesta de Corpus): El golfo de las sirenas, El laurel de Apolo, Eco y Narciso, Céfalo y Pocris, La hija del aire, La estatua de Prometeo y la Mojiganga de la muerte, entre otras. En este periodo Moliére se hace su propia fama; Milton escribe El paraíso perdido y Racine, Fedra.

Calderón escribe algunas obras cortesanas (la última: Hado y divisa de Leónido y Marfisa en 1680) y autos sacramentales hasta su muerte en 1681. De los ochenta y un años que duró su existencia, cincuenta y ocho estuvieron dedicados a escribir para el actor teatral.

\section{Técnicas escénicas}

Para Josef Oehrlein las variantes espectaculares de la España barroca se reducen a tres: comedia de corral, fiesta de Corte y auto del Corpus. ${ }^{12}$ Sin embargo, para nuestro estudio el teatro español del siglo XVII puede desglosarse hasta en seis tipos, que también se corresponden con seis estilos o técnicas de espectacularidad:

1. El teatro trashumante, junto con toda la tradición de los Carros de Comedias, austero heredero de los juglares y trovadores medievales y de la Commedia dell'Arte italiana, que deja entre sus mejores evidencias precursoras Los pasos de Lope de Rueda (con sus Cómicos de la Legua) ${ }^{13}$. Lo incluimos aquí porque sabemos que es un teatro muy popular con jerarquías actorales claras: bulubú [actor solitario], ñaque [dueto], gangarilla, cambaleo, etc., definidas éstas por Agustín Rojas Villandrando en 1603 (al iniciar justamente el Siglo Dorado). Aunque no se pueda detallar mucho sobre su escenotecnia precisamente por su carácter nómada,

\footnotetext{
${ }^{12}$ Oehrlein delimita su campo de estudio en El actor en el teatro español del Siglo de Oro sólo a las compañías legalmente establecidas en Madrid en esa época (compañías con licencia), por lo que deja de lado a los grupos trashumantes que no podían acercarse más de una legua a la metrópoli y las representaciones particulares realizadas por grupos familiares o por encargo en la privacidad de una casa.

${ }^{13}$ Se les llamaba a estos grupos compañías de la legua por no poder acercarse a menos de una legua de distancia (entonces circa una hora a pie o a caballo) de las ciudades donde tenían preferencia las compañías de título o reales debidamente acreditadas. (Oehrlein: 65).
} 
se conoce que en el mejor de los casos llega a disponer de templetes desarmables, adaptables a las condiciones de plazas y caminos. Mientras evocan un recuerdo de Cervantes (en los Entremeses) sobre la compañía de Rueda, Macgowan y Melnitz escriben:

el escenario estaba formado por cuatro bancos con tablones que los cruzaban a 60 centímetros del suelo. El fondo escénico era una manta vieja "detrás de la cual estaban los músicos cantando sin guitarra algún romance antiguo". Los atuendos y la utilería de tal compañía, cuando se representaba una comedia pastoril, podían caber en un saco, "y se cifraban en cuatro pellicos blancos guarnecidos de guardamecí dorado, y en cuatro barbas y cabelleras y cuatro cayadas poco más o menos”. Recordando los recursos escénicos y las tramoyas de su propia época [50 años después de Rueda], Cervantes observó que en una representación como las que hacía Rueda "no había figura que saliese o pareciese salir del centro de la tierra... ni menos bajaban del cielo nubes con ángeles o con almas". Por todo eso, Rueda "actuaba con la máxima destreza y naturalidad que pueden imaginarse". (Las edades de oro del teatro, 102. Énfasis mío).

2. Los corrales de comedias implican una teatralidad popular muy relacionada con las tesis de Lope: realista, costumbrista y accesible, con no muchos elementos escenográficos. El funcionamiento de los corrales está sujeto además al control del Estado y de la Ciudad de Madrid, como se deja ver en los tres Reglamentos promulgados respectivamente en 1608, 1615 y 1641 (Oehrlein, 27). Tienen además la función social de mantener los hospitales de la Ciudad de Madrid.

Resumiendo, el auditorio de los corrales tenía la siguiente estructura: el patio era una superficie despejada para los mosqueteros [hombres que permanecían de pie]. A ambas partes se encontraban las gradas y por encima de éstas, dos pisos de aposentos; de éstos, el superior suponía una mayor categoría. Delante de los aposentos estaban los corredores. Arriba del todo, bajo el tejado, se albergaban los desvanes. En la parte estrecha de los corrales, enfrente del escenario, a derecha e izquierda, había sendos aposentos pequeños; por encima y a todo lo largo de la entrada, la cazuela de las mujeres; encima, los aposentos del Consejo de Castilla y de la Villa de Madrid y más arriba aún, la tertulia, que a veces se cuenta como parte de los desvanes laterales. (Oehrlein, 23).

[.....] Consiguientemente, con los Corrales de la Cruz y del Príncipe disponían los actores madrileños de dos escenarios que tenían todas las instalaciones técnicas importantes [tablado elevado, luneta, trampillas, vestuarios, escaleras, galerías, balaustradas, corredores, aposentos, apariencias, telones de fondo y laterales, 
balcones, tejadillo en vez de techo, bastidores], aunque por lo que respecta al espacio en la escena $\left[31.75 \mathrm{~m}^{2}\right.$ y $47.04 \mathrm{~m}^{2}$, respectivamente $]$ y en los camerinos eran bastante pequeños. La posibilidad de usar máquinas en la configuración de decorados estaba bastante limitada dado este presupuesto espacial. La función de éste debía mediatizarla el telón dispuesto al fondo. (Oehrlein, 26. Énfasis mío).

3. Las funciones denominadas particulares son las representaciones de las comedias de corral contratadas para casas privadas ante un público predeterminado. Aplican también para funciones a pequeños círculos de la corte. Los espacios son habitaciones, cámaras y salas, y las funciones deben ser estrictamente a puerta cerrada. (Oehrlein 29 y 32).

4. El teatro cortesano es, por el público al que está dirigido, un teatro de mayor erudición temática (con personajes e historias de la nobleza o de la mitología) y sofisticación escenográfica (de ingeniería italiana). Aunque las representaciones, que por lo aparatoso llegan a denominarse fiestas, sean indistintamente en las cámaras reales, salas grandes y jardines de Valladolid, Burgos, El Escorial, Aranjuez, Toledo y Madrid, sus ámbitos más importantes son el Salón Dorado del Alcázar (Valladolid) y el Coliseo en el Palacio del Buen Retiro (Madrid):

Aun cuando en estos diferentes lugares se ha seguido representando indistintamente a partir de 1626, el teatro de la Corte ha tenido un desarrollo totalmente diferente del teatro de corral. En ese año llega a Madrid el ingeniero florentino Cosimo Lotti, al que Felipe IV le encarga que se ocupe en la Corte de los jardines, de las fuentes y, además, de la técnica teatral. Con Lotti llegó a España el arte escénico italiano, ya mucho más desarrollado. La forma italiana del teatro se diferenciaba del teatro de corral español en aspectos fundamentales: las representaciones tenían lugar en espacios cerrados, lo que hacía imprescindible la utilización de iluminación artificial, mientras que en los corrales, sin tejado, se representaba a plena luz del día, lo que hacía especialmente difícil la representación realista de escenas nocturnas. El teatro italiano contaba ya con una desarrollada técnica teatral que, gracias sobre todo a un solo logro, el escenario de perspectiva [invento atribuido al arquitecto Giovannio Battista Aleotti de Ferrara para el Teatro Farnese de Parma, construido por Aleotti en 1618], hacía palidecer todas las posibilidades que el teatro de corral tenía de lograr efectos ilusionistas. (Oehrlein: 34. Énfasis mío).

5. La Fiesta de Corpus, financiada por la Ciudad de Madrid (que además paga a los actores) es el hogar del auto sacramental, de vistoso despliegue escenográfico (con 
torres con maquinarias integradas y carros tirados por bueyes) y con un propósito predominantemente moralizador. ${ }^{14}$ Desde 1648 Calderón se hace del monopolio de la producción dramatúrgica de este festival. (Oehrlein: 40-43).

6. Finalmente, no hay que desconsiderar el teatro callejero local (distinto del teatro trashumante) que, en fiestas determinadas, incluye representaciones teatrales y parateatrales (mascaradas, música, baile, etc.) con escenotecnias múltiples.

En esta diversidad escénica, los elementos de una forma teatral influyen a las otras. Los actores incluso pueden alternar la prestación de sus servicios entre ellas: "Para el actor esto significaba que ningún lugar de representación le era totalmente extraño, pero también que constantemente se tenía que enfrentar a nuevas situaciones espaciales y técnicas." (Oehrlein: 47).

Aunque este estudio no pretende ahondar en las particularidades del espacio teatral barroco, sí es importante anotar que tanto el lenguaje (elevado en general) como la temática religiosa (de tratamiento casi hagiográfico) e histórica de El príncipe constante (con el infante de la casa real portuguesa Fernando dando su vida por Ceuta), así como las necesidades de tramoya, escenografía y efectos especiales patentes en la obra (barcos, ejércitos a caballo, batallas y apariciones fantasmales), sólo resolubles con los ingenios patrocinados por Palacio, hacen pensar que no está dirigida al vulgo (básicamente inculto), sino a la Corte (de nobles supuestamente doctos), pues aunque aún no se haya puesto en funcionamiento el Coliseo con su avanzada tecnología (eso será hasta 1640), ya el ingeniero italiano Lotti podía configurar espectaculares sucesos teatrales.

Desde que se introduce el escenario frontal, mejor conocido como la "caja italiana", España depende de Italia en casi todas sus innovaciones técnicas, incluida la iluminación y los telones, así como sus vistosos efectos especiales.

Lotti lleva ya tres años (desde 1626) trabajando para Felipe IV cuando Calderón termina El príncipe constante. La provisional tramoya escénica del italiano (su teatro portátil) seguramente es usada ese mismo 1629 para representar La selva sin amor de Lope de Vega, utilizando en los laterales del escenario, alineados uno tras de otro, cuadros

\footnotetext{
${ }^{14}$ En un nivel secundario en estas fiestas podían verse entremeses, como sería costumbre entre las jornadas de cualquier obra teatral, incluyendo los autos sacramentales.
} 
pintados sobre lienzos que, al introducirse sobre raíles en el tablado, originan un cambio de escena:

Un carácter peculiar de estos cuadros escénicos era el dibujo en perspectiva, que daba la ilusión de profundidad de campo en la escena y al mismo tiempo podía transmitir al público el sentimiento de que el espacio reservado al espectador continuaba en el imaginario mundo de la escena. (Oehrlein: 35. Énfasis mío).

Además de facilitar así la realización de las "comedias de tramoya", Lotti también introduce el telón de la boca del escenario (conocido hoy como "bocaescena" o telón principal), que puede separar la escena del espacio dedicado a los espectadores mientras no se representa. Este no se usa en el teatro de corral, su aplicación se restringe al teatro de la Corte.

Es posible que en las exigencias escénicas del texto de 1629 de El príncipe constante, Lotti encuentre el estímulo que requiere su imaginación para proyectar y materializar la maquinaria del futuro Coliseo (aunque seguramente el estreno de El príncipe constante todavía no gozó de tal maquinaria). Es decir, que en Calderón el escenógrafo haya encontrado a su dramaturgo ideal.

Pero también Calderón seguramente descubre con Lotti, y después con Baccio del Bianco $^{15}$, la tecnología idónea que puede convertir en realidad sus fantásticas alegorías. Una consecuencia tiene que ser que la pluma de Calderón prefiera entonces la maquinaria del Palacio a las limitaciones de los corrales para ver representadas sus obras, preferencia que puede comenzar a partir de una fiesta realizada en los jardines...

A su riqueza de ocurrencias [de Lotti] hay que atribuir el que una de estas pródigas escenificaciones tuviera lugar incluso en un pasaje poco adecuado para representaciones teatrales, pero que precisamente por eso era especialmente atractivo. En el estanque, que pertenecía al complejo palaciego, se representó en 1635 El mayor encanto, amor, de Calderón. [...] La representación tuvo lugar en la noche de San Juan. [...] En esta ocasión, por supuesto, Lotti tuvo oportunidad de emplear sus técnicas hidráulicas. (Oehrlein: 34 y $35)$.

\footnotetext{
${ }^{15}$ Cosimo Lotti murió el 24 de diciembre de 1640. En su sustitución como ingeniero de la Corte madrileña vino, hasta 1651, Baccio del Bianco, quien se estrenó como escenógrafo en 1653 con la pródiga Andrómeda y Perseo de Calderón. (Oehrlein: 38 y 39).
} 
Calderón dejará definitivamente de escribir para los corrales hasta $1651 .{ }^{16}$ Mientras tanto, no es difícil deducir que El mayor encanto, amor es la primera fiesta calderoniana, como conocemos hoy a estas ceremonias, mismas que se continúan hasta la muerte del dramaturgo, todas con elocuentes expresiones mecánicas y una enorme movilización de personal. Todo desde luego es bien aprovechado para las obras de teatro. La última es Hado y divisa de Leónido y Marfisa (de 1680), cuya descripción es elocuente:

En la primera jornada [de Hado y divisa...] se requiere un paisaje rocoso, una gruta y un río (sobre el que navegará un barco), en el segundo acto hay un paisaje de bosque y de rocas representado en los bastidores, que deja ver una gran peña en el fondo y que al final se abre y deja aparecer un gabinete real; en una segunda roca aparece incluso la sala de un palacio. Finalmente se presenta al público un decorado de montaña con el volcán Etna en erupción como atracción. En la tercera jornada, un bosque se transforma en jardín, éste a su vez en un decorado con árboles y montañas, se vuelve de nuevo al jardín y finalmente aparece una plaza como decorado ante el palacio real. Por supuesto que el aparato técnico del teatro de Palacio estaba dotado de máquinas de volar, ya que los poetas exigían el descenso de figuras... (Oehrlein: 37).

Toda esta modalidad espectacular tiene que afectar a los actores:

Desde la perspectiva de los actores, la actuación en la Corte real era honrosa y lucrativa, si bien exigía de ellos una manera de trabajar que se diferenciaba totalmente de la de los corrales: las apariciones en el escenario dominado por la técnica escenográfica y la utilización de maquinaria muy complicada en comparación con la de los corrales exigían un trabajo de ensayo muy exacto y, sobre todo, una disciplina y una disposición al rendimiento mayor. El dominio de esta técnica y el conocimiento de su efectividad proporcionaban al actor, frente al espectador, que tenía que dejarse impresionar por estas artes, una posición privilegiada. (Oehrlein: 39 . Énfasis propio.)

Es claro cómo en el Barroco la profesionalización del actor lo convierte en un lector especializado. Con todos estos elementos podemos afirmar que El príncipe constante, con su escenificación en 1629, es una obra que se inscribe justo en la transición del quehacer teatral en España de mero divertimento a una importante profesión.

\footnotetext{
${ }^{16} \mathrm{Si}$ bien los corrales sí lo siguen representando a él.
} 


\section{La actuación}

Hasta hace un momento, hemos seguido el estudio de Sirera para enmarcar el momento histórico de la teatralidad que habitara Calderón. Ahora nos apoyaremos en otros autores para comprender cómo se vive la vida del actor en ese mismo contexto. Entre ellos, principalente tenemos que considerar a Josef Oehrlein, pues es su indagación la que logra colocar el oficio del actor con claridad en su estamento profesional. Así pues, la mayoría de las siguientes citas se refieren a él, aunque paulatinamente debamos dejarlo, puesto que el nivel sociológico de su estudio no nos basta para describir -como requerimos aquí- las técnicas de interpretación actoral y sus implicaciones en la encarnación de la obra de Calderón.

Como se asume en general, "Lengua y gesticulación son los dos medios auxiliares más importantes de los que se sirve un actor para dar vida al texto" (Oehrlein: 152). De ahí que, especialmente en el Barroco, "el siempre pequeño círculo entre el que se reclutaban las nuevas generaciones de actores habla a favor de que las técnicas de representación eran tradicionalmente orales y de que los actores más jóvenes en cierta medida se formaban dentro del oficio durante el trabajo práctico." (Oehrlein: 152). La oralidad va ligada, en el teatro áureo, con la literatura. Oehrlein describe la dependencia del arte teatral barroco de su textualidad:

La obra núcleo de la representación teatral era la interpretación del texto (comedia, auto, fiesta) creado por el autor [el dramaturgo]. Hay que advertir que en el teatro español de comienzos del periodo estudiado, los textos fijados por escrito tienen la mayor importancia y -al revés de la italiana commedia dell'arte- se deja poco lugar para la improvisación. (153).

En efecto, además de implicar una mnemotecnia musical para su ejecutante a través de la rima y el ritmo, la versificación de la literatura dramática barroca enfatiza a oídos del espectador el carácter extracotidiano de la situación representacional, pero además:

[...] el estilo que hay en estos versos muy guardado es que la comedia sea en verso, y como por este camino se le quita al representante el albedrío de decir lo que quiere, y sólo ha de decir lo que compuso el poeta. (Casiano Pellicer [1598], Memorial impreso dirigido al rey don Felipe II, para que levante la suspensión en las representaciones de comedias, citado en Rodríguez Cuadros, en Díez Borque: 38). 
De todos modos, la fidelidad al texto en su representación puede ser muy relativa, dependiendo de las condiciones objetivas en que se tiene que escenificar, las condiciones disponibles para la producción del espectáculo, o bien, las condiciones diversas de recepción en los distintos lugares de representación. Aunque casi siempre las adaptaciones las deciden el autor de comedias (empresario) y los comediantes (actores), Oehrlein demuestra, a partir del análisis hecho por Arnold Rothe a El mágico prodigioso y con su propio estudio del manuscrito de La humildad coronada, ambas de Calderón, cómo el dramaturgo mismo podía ser quien operara estas versiones adaptadas, sin mayores complicaciones:

En la mayoría de los casos esto significaba una adaptación a la situación personal de la compañía o a una situación interpretativa especial. La especie de ingerencias en el texto podía ser muy variada, y éstas iban desde la modificación de términos aislados o pasajes del texto, pasando por la fusión de papeles (cuando la compañía no contaba con suficientes actores) hasta la supresión de mayores o menores guiones. (Oehrlein: 153).

En otras palabras: el texto dramático nunca era visto como un documento definitivo, sino como uno de trabajo, cuya culminación se alcanzaba sólo con la representación, y sólo durante ella. Esto confirma que la lectura integral del texto dramático sólo culmina hasta su representación.

El vestuario tampoco tenía por norma una fidelidad absoluta, al menos en lo concerniente a la caracterización histórica:

El rasgo más destacado del vestuario usado en el teatro español del siglo XVII es que no representa en absoluto una reconstrucción exacta de determinados trajes históricos, sino que refleja, sobre todo, la moda de cada momento y que reproduce sólo alusivamente las indicaciones específicas de la vestimenta de otras épocas históricas y círculos culturales. (Oehrlein: 157).

Esto permitía otro tipo de exposición, por mucho más clara, ante el espectador:

Al no tomar en consideración una detallada fidelidad histórica, se podía indicar más fácilmente en la vestimenta la posición social de cada uno de los papeles. Sólo en épocas muy recientes se puede observar un mayor interés por la investigación de cuestiones tales como el vestuario del actor. (Oehrlein: 157). 
Juan Manuel Rozas, en Sobre la técnica del actor barroco, cita a Mateo Alemán para inferir las virtudes más importantes del actor barroco: desenvoltura, dicción, físico y memoria:

Sin duda tenía partes grandes para el ejercicio cómico; porque vergüenza había años que no habitaba en mí; era expeditísimo en el hablar, no mal talle ni donaire, memoria prodigiosa. (Mateo Alemán, en Rozas.)

Lo cual corrobora Lope de Vega en unos versos de El guante de doña Blanca:

...que ha de tener el buen representante

$[\ldots .$.

acción, memoria, lengua y osadía.

(Lope de Vega, El guante de doña Blanca.)

Estos fundamentos primarios del actor barroco no se contradicen con las habilidades de verosimilitud emotiva que, para goce del público, un actor apasionado puede desarrollar. Rozas considera: "La pasión la inventa el dramaturgo, pero debe sentirla -saber sentirla realmente- para poder expresarla; pasa luego al actor y de nuevo éste debe sentirla realmente, para comunicarla al espectador, en quien realmente revive", a partir de Lo fingido verdadero, de Lope de Vega:

El imitar es ser representante; pero como el poeta no es posible que escriba con afecto y con blandura sentimientos de amor si no le tiene, [.....] así el representante, si no siente las pasiones de amor, es imposible que pueda, gran señor, representarlas; una ausencia, unos celos, un agravio, un desdén riguroso y otras cosas que son de amor tiernísimos efectos, haralos, si los siente, tiernamente; mas no los sabrá hacer si no los siente. (Lope de Vega, Lo fingido verdadero.)

Por otra parte, es interesante la importancia dada a la acción no sólo como movimiento físico, sino como efecto emocional que alcanza al espectador, asociando la acción con la 
emoción en un movimiento de los ánimos. Rozas explica que el uso de mover a es un verbo corriente en los textos sobre teatro de la época.

No en vano [mover $a$ ] es un tecnicismo procedente de las retóricas. Lo encontramos desde el anónimo defensor de la comedia de 1649, cuando explica que ver a Antonio de Prado en el personaje de Carlos V, ya viejo, es recomendable, pues no hay quien "no salga edificado y movido", hasta en los más serios preceptistas: "Por movernos los ánimos", dice el Pinciano; "mover a los oyentes a risa", dice Rizo. Pasando por los propios dramaturgos: "Cuando a llanto y pasión puede moveros", escribe Rey de Artieda. (Rozas).

Podemos resumir que las cualidades del actor español barroco son: buena memoria, voz (volumen y dicción), desenvoltura (osadía), acción (entendida como movimiento físico tanto como emocional) y presencia (buen físico, talle y donaire). Al no hallar evidencias de una metodología actoral estandarizada, Juan Manuel Rozas determina que al parecer, estas virtudes "son hijas 'del natural', y se desarrollan con 'la experiencia', sin que se hable nunca de arte -ni viejo ni nuevo- de representantes."

A pesar de sus virtudes, como en casi todas las épocas en casi todo el mundo, la fama del actor en la sociedad de la España del siglo XVII era moralmente dudosa y discutida.

De todo lo cual, se saca lo que muchas veces se ha dicho; que el farsante que trata cosas torpes, como infame y sujeto á pecado, debe ser del todo privado de los sacramentos de la iglesia, si no propusiere de dejar tal profesión; y si muriendo no diere, por lo menos, señal de haber mudado propósito, no le deben dar sepultura eclesiástica, ni hacelle obsequias á la manera que se hace con los demás pecadores manifiestos y públicos [...] Y desta suerte, juzgo que sean las compañías de representantes que andan ordinariamente por España, vendiendo su arte por dineros; pues es cierto que abiertamente ó de callada, casi en todas las representaciones, proponen á los oyentes, torpeza y deshonestidades, engaños de rufianes, amores de rameras, fuerzas de doncellas, y otras cosas que no hay por qué referirlas, por su deshonestidad; y por tanto, como afeados con muchas torpezas, juzgo que deben ser echados de la iglesia y apartados de la sanctidad de los sacramentos. (Juan de Mariana, Tratado contra los juegos públicos [De spectaculis], citado en Oehrlein: 64).

De ahí que la estética del decoro consistiera no sólo en una alineación incondicional a las jerarquías sagradas de Dios, la Iglesia, el Rey, el Estado, la nobleza y el honor en general, sino más específicamente en representar personajes y conductas a seguir. Acatar (más o 
menos) las normas de la estética del decoro le permitió al actor no sólo sobrevivir a los ataques de algunos círculos eclesiásticos ${ }^{17}$, sino ganarse además la protección oficial.

Otras reglas morales a las que estaba sometido y que tenían un carácter legal eran: el patrocinio caritativo de hospitales, la prohibición de imágenes impúdicas, la sanción de vicios y actos deshonestos, la apología de la religión y del honor:

El hecho de que el tratamiento del motivo del honor se realice en el escenario según reglas estrictas, confirma además el carácter ritual del juego en el teatro de corral. En el drama de honor basta ya la más mínima sospecha para poner en funcionamiento el implacable mecanismo de la venganza. El pariente masculino más próximo a la mujer, cuando la sospecha se ha consolidado, está obligado a intervenir y procurar el restablecimiento del honor: en secreto, si la sospecha no se conoce públicamente, y en público cuando la pérdida del honor es manifiesta. Y cuando la justicia por propia mano entra en conflicto con el ordenamiento jurídico, el rey debe intervenir como instancia última y definitiva para restaurar el orden. (Oehrlein: 61).

Su respeto permitió que, a diferencia de Inglaterra, en España sí se autorizara la actuación femenina y que, poco a poco, el perfil del actor ante la sociedad se acercara a lo honorable.

Que las mugeres representen en habito decente de mugeres, y no salgan a representar en faldellín solo, sino que por lo menos lleuen sobre el ropa, vaquero, o basquiña, suelta, o enfaldada, y no representen en habito de hombres, ni hagan personages de tales, ni los hombres, aunque sean muchachos, de mugeres. (Reglamento de teatros de 1615, citado en Oehrlein: 163). ${ }^{18}$

José Antonio Mateos Carretero (El teatro en Parla en el siglo XVII) recuerda que una condición básica era que "la mujer actriz debía ser casada y estar en compañía de su marido".

\footnotetext{
${ }^{17}$ Por ejemplo Fray José de Jesús María, carmelita descalzo, quien ataca al actor como miembro podrido de la sociedad en Primera parte de las excelencias de la virtud de la castidad, glosado por Cotarelo en Bibliografía de las controversias sobre la licitud del teatro en España. Ver Rodríguez Cuadros, "Registros y modos...": 36 y 37, y también el capítulo de Oehrlein sobre "El actor en la sociedad", donde dice el fraile: "Concedamos que los representantes sean miembros de este cuerpo de la república, como los demás estados della, que es lo que ellos pretenden dar a entender aquí: conforme a lo qual conviene que se advierta, que quando algún miembro está ya podrido, se corta y entierra, porque no corrompa e inficione todo el cuerpo, y lo mismo es necesario que se haga en éste" (1601, en Cotarelo: 372 a, citado en Oehrlein).

${ }^{18}$ Aquí podemos confirmar que el seguimiento de estas normas era más bien flexible por parte de autores, poetas y actores, como recordamos en La vida es sueño de Calderón, donde Rosaura abre la obra en traje masculino (aunque lo hace precisamente para proteger su honor). En el capítulo VI trataremos otros ejemplos, que de cualquier manera no anulan la existencia objetiva del Reglamento.
} 
Tomando en cuenta que la presencia del actor se volvió necesaria para muchas celebraciones privadas (cumpleaños, santorales) de la Casa Real y de las fiestas de Corpus, mismos que se hicieron parte integrante y fija del calendario eclesiástico, podemos afirmar que el actor español del siglo XVII no sólo se convirtió en un medio solidario importante para el mantenimiento de los hospitales de la ciudad (lo cual permitió la defensa moral y desarrollo de su arte), sino que fue también un destacado factor de formación religiosa (en los autos) y elemento de divertimento para el pueblo y la Corte. Con todo ello alcanzó de forma empírica un nivel profesional que le ganó cierta tolerancia e incluso estímulo por parte de la gente, y de las instituciones del Estado y de la Iglesia:

Considerados en su conjunto, son cuatro factores los que durante la época investigada han estimulado constantemente y fomentado el desarrollo del gremio de actores:

- la producción de piezas por poetas cuya calidad literaria y prestigio social eran casi inatacables [como Calderón];

- la demanda de diversión de los numerosos ociosos que vivían en Madrid [a partir de inmigrantes provenientes de Castilla, Galicia y Asturias que buscan vivir cerca y a costa de la Corte, trasladada ahí primero en 1563 y definitivamente en 1605 (siguiendo a Oehrlein: 12 y 13)];

- el carácter benéfico del ejercicio teatral que desde un principio ha estado en relación con los hospitales municipales;

- la necesidad de representación de la Corte, Villa e Iglesia [se necesitan actores para cumplir las representaciones de las ceremonias de Corpus].

(Oehrlein: 280 y 281.)

Al respecto, Oehrlein también observa la gran importancia que la comunión teatral adquiere en el Barroco como integrador social: "la vivencia cúltica comunitaria constituye el punto medio integrador de todos los reunidos en torno a la representación" (54), en la cual la función del actor es claramente indispensable, de donde concluye que el estamento profesional del actor del Siglo de Oro fue el de un perito ritual:

Con ello, el actor se manifiesta en una función cuasi sacerdotal. Su pericia ritual consiste, en todo caso, en que previamente conoce el desarrollo del rito como concepto, que él dirige durante el acontecimiento con la ayuda de diversos mecanismos. Este conocimiento del desarrollo probable de la representación antes de que haya empezado, junto al conocimiento del principio funcional de cada uno de los elementos con los que se dirige el curso de los acontecimientos (el conocimiento de la naturaleza de la maquinaria escénica, que para él no representa un prodigio, sino un artilugio técnico), y, finalmente, su instrumental "artesano" (dicción, gestos, mímica, dotes de bailarín, cualidades musicales) le confieren en la comunidad teatral una posición destacada. (Oehrlein: 63. Énfasis mío). 
Aunque en su carácter más sencillo la "Tarea del actor era mediar entre las intenciones del poeta y los intereses del público" (Oehrlein: 185), la razón última de este "experto configurador del ritual en la representación teatral" (Oehrlein: 277) es producir un efecto trascendental:

Meta esencial de la interpretación de los actores en la época investigada es una fuerte carga emocional del suceso escénico y una trasposición de los efectos creados por los actores en sí mismo al público. Precisamente así surge, no una separación entre el representante y el espectador, sino, en el caso ideal, [...] una comunidad emocional de todos los congregados para el ritual de la representación teatral. La posición dirigente del actor en este suceso colectivo es, por supuesto, indiscutible. (Oehrlein: 279).

No existen, sin embargo, manuales ni poéticas -como tales- sobre el actor español en el siglo estudiado. ${ }^{19}$ Empero, en la búsqueda por sistematizar una teoría del actor barroco a partir de obras, registros visuales, didascalias textuales, tratados estéticos, filosóficos y morales, y los modos de representación de la época, Evangelina Rodríguez Cuadros logra establecer un puente claro entre las técnicas del oficio en el siglo $\mathrm{XVII}^{20}$ con las teorías de actuación que aparecieron entre los siglos XIX y XX:

Así, Francois Delsarte (1811-1871) explicaría, con su ley de correspondencia la vinculación de funciones espirituales y corporales que nosotros hemos convocado con la fisiognómica [estudio del gesto corporal]. Mikhail Chekhov (1891-1955) y su teoría del gesto psicológico (gesto tipo o psicofísico) se adentraría en un análisis válido para el decoro. Stanislavski encontraría un thesaurus inacabable para su relación simbiótica personaje/actor en los reiterados como si... del drama barroco ("hace como que le pesa", "sale como oyendo la voz", "hace la acción de querer arrancar las flechas del pavés"). Y Brecht tendría pocas dificultades para admitir como elementos distanciadores (y doy sólo dos ejemplos), la camisa llena de palominos que denuncia en los entremeses al gracioso o el maquillaje simbólico (color amarillo o cetrino) que identifica al melancólico. (Rodríguez Cuadros, "Registros y modos de representación en el actor barroco", en Díez Borque: 52).

\footnotetext{
${ }^{19}$ Una poética particular sobre el actor es uno de los productos que intentaremos aterrizar con esta tesis.

${ }^{20}$ Entre la teoría y crítica del Barroco que toca la figura del actor, Rodríguez Cuadros revisa desde tratados morales como Bienes del honesto trabajo, y daños de la ociosidad, en ocho discursos, de Pedro de Guzmán (Madrid, 1613) y Primera parte de las excelencias de la virtud de la castidad, de José de Jesús María (Alcalá, 1601), que sancionan el oficio vulgar del actor; cartas oficiales como Memorial impreso al rey don Felipe II, para que levante la suspensión en las representaciones de comedias, de Casiano Pellicer (1598), que le defienden; intentos descriptivos como el Discurso theológico sobre los teatros y comedias de este siglo, de Ignacio Camargo (Salamanca, 1689), el Tesoro de la lengua castellana, de Covarruvias (1611) y el Diccionario de autoridades (1726-1739); hasta el Tratado de las pasiones, de René Descartes (1649).
} 
A pesar de no haberse estructurado una poética, una gramática o una tejné tan elaborada como en otras tradiciones actorales, Rodríguez Cuadros defiende al actor barroco español como un agente cultural importante: "un cuerpo que elabora mitos, símbolos, conductas sociológicamente significativas" (37), sin la cual el Siglo de Oro sería, sencillamente, inexplicable: "El actor se ofrece a que su cuerpo sea soporte de conductas significativas, inserta su carne en el conjunto de los significados admitidos para el siglo XVII." (37. Las cursivas son propias).

Hasta aquí podemos afirmar que con las condiciones culturales de la España del siglo XVII el actor que conoce Calderón logra desarrollar un nivel profesional más elevado que el de un mero oficio artesanal, basado fundamentalmente en la comunicación verbal y en una estética relativamente limitada por la moral en curso. Su competencia comunicativa verbal tiene a su vez dos basamentos: la oralidad y cierta fidelidad al verso, entendida esta última como una competencia lectora especializada capaz de asumir decisiones interpretativas críticas. La expresión oral, por su parte, se apoya de la gestualidad y de la interpretación emotiva para comunicar fielmente la intención del poeta dramático; sin embargo, la fidelidad al texto puede flexibilizarse según las condiciones específicas de producción, representación y recepción del espectáculo sin que ello implicara faltar a la intentio original (tal y como el mismo Calderón lo permitió y operó en al menos El mágico prodigioso y La humildad coronada), la cual, en su carácter más esencial de acuerdo con la estructura con que se escriben los dramas, tendría que interpretarse contundentemente como el ver la obra escenificada.

Al ser el ente mediador entre la intención del dramaturgo y su receptor final el espectador, el actor se confirma como el agente central del hecho teatral. Es el dirigente -en los hechos- del acto ritual representacional, por lo que es él quien propicia los efectos estéticos, emocionales y sociales consecuentes a este acontecimiento. En suma, el cuerpo del actor es el depositario de una ofrenda artística (la obra) con las características rituales de una comunión (actores-espectadores).

Сuerpo es una figura que emerge al final de este apartado de modo muy útil para entender al actor y sus funciones en la creación del sentido teatral: un Cuerpo que encarna la palabra del poeta creador; por lo tanto: el Cuerpo del actor es también verbo encarnado, y además es: Cuerpo habitáculo de una pasión (peripecia emocional de un personaje 
proyectada ante el espectador para su recepción empática que le mueve a sentir-vivir la misma pasión): Cuerpo animado con el espíritu de un personaje (posesión herética o casi). Esta alegoría corporal resulta más interesante considerando el contexto, de algún modo místico, en que el actor de El príncipe constante de Calderón participa en la escenificación del drama de un mártir de índole claramente espiritual. La profundidad del efecto místico de tal escenificación dependerá tanto de las características del texto (drama), como de los recursos de la producción, como de las condiciones de recepción, como de su ejecución escénica (la actuación en sí). En capítulos subsiguientes indagaremos hasta qué nivel interpretativo se puede llevar la pasión del infante Fernando en su lectura mediatizada por un cuerpo actoral. 


\section{CAPítulo II: DRAMEMA ${ }^{21}$ \\ Análisis semiológico de El Príncipe Constante}

\section{¿Semiología o semiótica teatral?}

En La lección inaugural (1989), Roland Barthes explica que la semiología es la ciencia de todos los signos que surge de la lingüística. Ya en La semiología (1978), Pierre Guiraud precisa que "La semiología es la ciencia que estudia los sistemas de signos: lenguas, códigos, señalaciones, etc." (Guiraud 1978: 7.) Y si bien para Guiraud semiología es lo mismo que semiótica, él mismo aclara que semiótica se refiere más a un estudio de los signos especialmente no lingüísticos. Umberto Eco es tal vez más exacto cuando afirma que la semiótica es un "estudio de los sistemas de signos que no dependan de la lingüística (leyes del lenguaje)" (Eco: 1986, La estructura ausente: 13). Sin embargo, Eco acepta el término semiótica para cubrir todas las posibles acepciones de los términos semiología y semiótica, con base en la decisión del comité fundador de la International Association for Semiotic Studies (enero de 1969, París, citada en Eco 1986).

Nosotros consideramos que una separación entre semiología y semiótica es prudente si hablamos de elementos lingüísticos en el sistema de signos estudiado. Esto es, como diría Anne Ubersfeld: “... partiendo de la hipótesis del hecho teatral como relación entre dos conjuntos de signos, verbales y no verbales.” (1989, Semiótica teatral: 20. Énfasis propio.) En este sentido, el estudio del sistema de signos que es el teatro, encaja más en una "semiología" (por incorporar signos verbales) que en una "semiótica" (definición que tiende a desincorporar esos signos). Analicemos este sistema.

\section{¿Signo o sistema de signos?}

Anne Ubersfeld observa que “debemos descartar, en rigor, la noción de 'signo teatral'; [pues] en la representación no se dan elementos aislables equivalentes a los signos

\footnotetext{
${ }^{21}$ Este capítulo fue presentado en una primera versión como una ponencia en el IV Congreso de Investigación Teatral de la Asociación Mexicana de Investigación Teatral (AMIT), celebrado en la Universidad de Sonora, del 2 al 4 de mayo de 2001, bajo el título La textura poética del drama de Beckett. Formó parte también de la tesis de maestría Perspectivas sobre Samuel Beckett y Heiner Müller con base en la creatividad minimalista (México: UNAM, 2003), y es parte fundamental del proyecto de investigación permanente Escenoma del Laboratorio de Teatro Libertad.
} 
lingüísticos, con su doble carácter de arbitrario (relativo) ${ }^{22}$ y de doble articulación (en morfemas y fonemas)." (Semiótica teatral: 19 y 20.) No obstante, ella misma anota que cabría considerar como sistema de signos excepcionalmente articulado el cuerpo del actor, además de insistir en que el texto teatral sí puede ser analizado como objeto lingüístico y de precisar también que:

La representación teatral constituye un conjunto (o sistema) de signos de naturaleza diversa que pone de manifiesto -si no total al menos parcialmente- un proceso de comunicación en el que concurren una serie compleja de emisores -estrecha y recíprocamente relacionados-, una serie de mensajes -igualmente relacionados, en este caso según unos códigos extremadamente precisos- y un receptor múltiple presente en un mismo lugar. Que el receptor no pueda, por lo general, responder en el mismo código que el emisor [...] no implica, en modo alguno, que no se dé comunicación. (Semiótica teatral: 20.)

En otras palabras, hablar de semiología teatral involucra tratar con una noción estricta de complejidad: "Abismo entre el texto, de lectura poética siempre nueva, y la representación, de lectura inmediata" (Semiótica teatral: 11.) Para evitar cualquier confusión, cada vez que en este trabajo hablemos del signo teatral habrá de entenderse que nos referimos al sistema de signos teatrales en todo su conjunto.

\section{Arte de la paradoja}

Acerca del teatro nos dice Carmen Leñero: "La realidad señala con su presencia [la del teatro] que existe y que a la vez no existe" (Leñero 2000, La luna en el pozo: 14.) El teatro es un rito donde el actor es depositario de dos naturalezas: una real, que es la suya propia (que existe), y una ficticia, que es la del personaje (que no existe). Desde este punto de vista, podemos ver que el signo teatral es un reflejo de dos mundos, que es un signo no unitario, es decir, que es múltiple, polisémico. Pero el teatro es todavía más. La misma Leñero dice, en un poema, que el arte teatral es una

Cadena de suplantaciones para hacer presa del sentido. (Leñero 2000: 80.)

\footnotetext{
${ }^{22}$ Ubersfeld nos recuerda que, según Saussure, el signo lingüístico se caracteriza por su arbitrariedad, es decir, por la ausencia de relación visible entre el significante y el significado: la palabra silla no se parece a una silla (en Semiótica del teatro: 21.)
} 
Esta reflexión poética ilustra la naturaleza colectiva (una cadena: poeta, dramaturgo, director, actor y personaje) y representacional (simulación de otra realidad: suplantaciones) del teatro, así como su vocación por capturar y retener la atención de un espectador (que es presa del sentido). Leñero ilustra también el carácter polisémico del teatro (cadena de suplantaciones: sistema de signos). El signo teatral es múltiple, más complejo que otros signos que, incluso, pueden constituirlo (literatura: palabra hablada y escrita; música y danza; artes visuales: pintura, escultura y arquitectura; etc).

Eco y Guiraud, como muchos otros críticos, admitirán esta complejidad del signo teatral. Se trata de un macro-lenguaje que abarca varios lenguajes, incluido el verbal o lingüístico (en muchos de los casos). Por esto mismo es que el término "semiología" nos parece más adecuado, precisamente por no omitir la cuestión lingüística. Incluso Fernando de Toro, al elaborar su Semiótica del teatro (1987), después de la portada desarrolla todo su exhaustivo estudio en términos semiológicos, ${ }^{23}$ obviando que es improbable desvirtuar al signo lingüístico como uno de los elementos asociados al signo teatral.

En los siguientes párrafos realizaremos un desglose de la caracterización semiológica del teatro según De Toro, para lo cual haremos un uso muy particular de mayúsculas, negritas y cursivas que permita distinguir sus categorías y niveles, especialmente ahí donde se vuelven homófonos (Texto Espectacular y texto espectacular), antes de proponer una adecuación más pertinente.

De Toro, al hablar de Texto en el teatro habla de un Texto Dramático y de un Texto Espectacular. Es decir, que se requiere de la colaboración entre dos tipos de escrituras para alcanzar un discurso teatral completo.

La primera escritura se refiere a la dramaturgia, a la propiamente dicha puesta en texto (en papel) de la obra. De Toro llama a esta escritura Texto Dramático, y analiza dentro de él un funcionamiento textual y un funcionamiento escénico. El funcionamiento textual es la lectura que se hace de la obra como literatura. El funcionamiento escénico es la lectura que nos hace vislumbrar, imaginar o prever el espectáculo posible que emergería del papel, es decir, su competencia como partitura espectacular. El investigador chileno-canadiense se refiere, por otro lado, a otro tipo de

\footnotetext{
${ }^{23}$ El ensayo sólo lleva lo semiótico en el título. Al interior, igual que Ubersfeld, cambia el término por "semiología".
} 
escritura, a otra textualidad, quizá más cercana a la teoría de la recepción que a la semiología, textualidad que tiene que ver con la posibilidad de percibir todo como texto, es decir, ver todas las cosas con ojos de lector, leerlo TODO.

En el teatro, este ámbito es el del Texto Espectacular, el texto que se escribe sobre el escenario, que De Toro subdivide en el texto de la puesta en escena y el propiamente texto espectacular.

El texto de la puesta en escena son los arreglos que hacen los intérpretes (actor, director, y escenógrafo o decorador) al texto dramático para decidir sobre alguna(s) de sus posibles lecturas, es decir, se trata de acotar la polisemia de la dramaturgia, sus ambigüedades o lugares de indeterminación (como les llama De Toro) para obtener una virtualidad espectacular, un boceto claro del montaje. Es así como la literatura se convierte en un libreto de dirección (para el director o régisseur), una partitura de entonación y acciones físicas (para el actor o performer), un libreto de iluminación y sonorización, o una maqueta de escenografía.

Finalmente llegamos a la puesta en escena, al propio texto espectacular, como lo llama De Toro, que es una escritura conjunta, colectiva, entre varios intérpretes, sobre el espacio escogido como escenario. (Más adelante discutimos esta categorización.) Aquí, De Toro distingue entre los códigos espectaculares y las convenciones teatrales.

Los códigos espectaculares (gestos, palabras, silencios, manejo de las distancias, etc.) son signos transformados a partir de los códigos cotidianos de comunicación, textualidades (en el sentido de elementos comprensibles como lenguajes) culturales que, llevadas a escena, dejan de ser cotidianas para inscribirse en un contexto estético y, por tanto, con mayor carga de significado, de sentido.

De Toro indica que las convenciones teatrales, por otra parte, van desde las Generales, como el pacto de cooperación del espectador, quien acepta asistir a una realidad diferente, aunque lo que va a ver no es propiamente realidad, sino la realidad del arte, y someterse a ella por el tiempo que dure el espectáculo; pasando por las Particulares, como el estilo de interpretación (por ejemplo, el expresionista, el del absurdo [si es que existe], el de la Comedia dell'Arte, el del teatro Nô, el del Kabuki, o el realista); hasta las Singulares, que cada puesta en escena genera y que, eventualmente, tienden a convertirse en Particulares y Generales (la Convención Particular de una representación del absurdo, por 
ejemplo; o bien, el estilo personal de dirección de Goethe o de Grotowski para escenificar a Calderón).

Tarea de la semiología -además- ha sido definir los rasgos primordiales de "la teatralidad":

un modo de representación integral que no procede por secuencia sino por sincronía, y que manifiesta nuestra facultad de imaginar un micromundo virtual, de transmitirlo tal y como lo percibe un sujeto in situ, y en términos de un acontecer en tiempo presente para el interlocutor. [...] El teatro se hace con los ingredientes de la realidad material: espacio, tiempo, cosas, cuerpos, voces, contactos, movimientos, tensiones, todos ellos elementos que se condensan y exponencian con el fin de ser intensamente percibidos. (Carmen Leñero. "Palabra poética y teatralidad". 230.)

En estas explicaciones se habla del actor a partir de una partitura de acciones físicas y verbales, de una escritura colectiva sobre el plano escénico (obviamente una escritura corporal con base en el movimiento) y de convenciones representacionales. El nivel de codificación (muy formal en las tradiciones orientales, y emotivo-psicológico en Occidente) permite llegar a comunicar estéticamente las tensiones de un mundo virtual como si fueran reales. Lo interesante es que lo son: el esfuerzo físico y emocional del actor no son falsos. Las dos dimensiones de realidad vividas durante la representación teatral denuncian que con respecto al estudio de este sistema de signos todavía falta mucho por desarrollar. Una cuestión pendiente, evidentemente, es la semiología del actor, sobre la cual se discute su volatilidad y especificidad en cada representación, que la hacen inasible.

Se trata de objetivar un tipo de comportamiento humano, el del actor, que posee aumentados todos los problemas que han hecho, por ejemplo, que la psicología sea una ciencia de reciente aparición. La dificultad de separar sujeto y objeto (o herramienta) en la actuación, añade obstáculos. (Raúl Serrano. 1996. Tesis sobre Stanislavski en la educación del actor. 16.)

Al respecto de la objetivación del funcionamiento semántico actoral, Anne Ubersfeld ha hecho grandes aportaciones:

Il est au carrefour des codes: visuel et auditif; - des sous-codes: gestuel, phonique, lingüistique. Il traverse les codes inconscients, idéologiques et culturels. Tout le jeu des signes visuels s'accroche à lui, à son corps (costume, maquillage, masque), à ses mouvements (objets, décor) et c'est sur lui que se pose la lumière. (Anne Ubersfeld. L'école du spectateur. 165.) 
Estas características inestables del quehacer actoral dificultan hablar de un texto espectacular en tanto que documento estable. Consecuentemente, conviene que precisemos una posición particular frente a la noción del espectáculo como "texto" espectacular. Dado que, en sentido estricto, se entiende texto como una estructura perdurable, una textura, como sí lo es el texto dramático en tanto que literatura, el término no nos parece el más apropiado para referirnos a la fugacidad del acontecimiento escénico. El espectáculo es efímero y mutable, sólo permanece inmutable y fijada para siempre la literatura dramática. Por otro lado, no conviene nombrar igual a la categoría Texto Espectacular (general) y a la subcategoría texto espectacular (particular), pues se presta a confusión. Por lo tanto, para esta última categoría y para referirnos en adelante a la noción semiológica del espectáculo (la creación colectiva de la representación) proponemos el término más prudente de discurso escénico. Asimismo, llamaremos texto espectacular al boceto del montaje, es decir, a la lectura, adaptaciones y arreglos hechos al texto dramático para hacerlo una partitura del espectáculo. Sobre esto enseguida mismo es obligado abundar.

\section{Textualidad, textura y discurso}

La actuación concentra en el cuerpo del actor (físico, talento, técnica, disciplina) todos los elementos poéticos del texto dramático, más todo el trabajo colaborativo donde se funden varios contextos sociales y personales y, sin embargo, hay también un trabajo individual que no puede mezclarse con el de la compañía. ¿Qué tanto encarna este cuerpo un texto ajeno, y qué tanto un discurso propio, original? ¿Podríamos hablar de una textura al referirnos a la escritura que realiza el actor sobre un escenario teatral mientras es leída por el espectador?

Gabriel Weisz nos recuerda que ya Roland Barthes en Mythologies y Jaques Derridá en De la grammatologie han definido a la textualidad por fuera del uso restringido al objeto literario, resquebrajando las fronteras entre la literatura y otras prácticas de significación asociadas a la verbalidad o a la no verbalidad (Cfr. Dioses de la peste 166.) En todo caso, no dejamos de asociar la idea de textualidad con una estructura estable, perdurable y, por lo tanto, a la que se puede acceder de modo recurrente.

Pero la naturaleza de la textura actoral se diferencia de la noción de texto como una escritura perenne, dado que la actuación teatral implica una redacción efímera, volátil al 
momento mismo de su creación y su lectura. Dado que entonces esta proposición tampoco parece sostenerse, preferimos optar simplemente por discurso (como no podemos hablar de la actuación como una textualidad autónoma, pero tampoco de la existencia de una textura, dada la volatilidad del signo teatral, del que no queda documento integral, entonces hablaremos de discurso.) Discurso en tanto que enunciación de un signo, o mejor dicho, de un conjunto de signos, exposición efímera de un mensaje, acontecimiento comunicativo. Se trata de la volátil articulación de diversos elementos con un fin comunicativo, única en cada representación, y evidente en la interpretación escénica de El príncipe constante, discurso como gesto corporal complejo e inestable.

El intérprete es portador de una concepción escénica de su director, así como responsable de salvaguardar la esencia literaria-poética del dramaturgo. Por otra parte, si bien el actor no está absolutamente obligado a considerar actuaciones anteriores, sabemos que las comparaciones son inevitables. Todo esto crea un horizonte de expectativa anterior al levantamiento del telón y es un macrorrelato que rebasa al mismo actor. Así, el más grande problema del actor es, precisamente, hacer que el verbo se haga carne.

La residencia del que escribe es la página en blanco, la del actor es el cuerpo dispuesto. (Luis de Tavira. El espectáculo invisible. 73.)

Hablando del trabajo individual, la actuación propicia en el cuerpo del actor un espaciotiempo insólito donde cohabitan dos materiales: el del actor y el del personaje, que se materializa en la figura que percibe el espectador. El actor tiene una experiencia vital, una formación profesional y un proceso de ensayos específicos, pero también circunstancias personales diferentes para cada función, todo lo cual nos permite reconocer a la persona detrás del personaje, entendiendo a la persona del actor, o sea a la persona en situación actoral, como un cuerpo donde se suman talento natural y virtuosismo técnico. Como el talento y el virtuosismo son cualidades distintas en cada persona, es obvio, como ya vimos, que la interpretación que el actor hace del príncipe Fernando de Portugal cobra características únicas (incluso con cada función, tomando aun en cuenta las variables diarias de sus circunstancias personales.)

Las limitaciones a superar y las decisiones más importantes por tomar giran, luego entonces, alrededor del actor, pues él es el portador del concepto escénico. 
El cuerpo del actor evidencia las tensiones creativas que se dan entre la literatura y el espectáculo, como en un combate: "stage versus page", plantea William B. Worthen (1997, Shakespeare and the authority of performance: 4), como proponiendo que, además del entramado argumental de la obra, hay que hablar del esfuerzo que implica el montaje escénico mismo. Esta lucha consiste en someter a una persona a un proceso de identificación, aunque sea estético, con un personaje ficticio. El arte de actuar, al menos en Occidente, supone, efectivamente, tensar un instrumento físico, que es el cuerpo del actor, hasta sus máximos límites expresivos, para representar a un ente de papel. Si en esta tensión hay una labor creativa, entonces debe existir un discurso actoral y, por lo tanto, una función autoral (“authority” [¡autoridad!], plantea Worthen) escénica específica.

\section{El discurso escénico del actor}

De antiguo se reconoce que la encarnación de un personaje por parte del actor, al menos en la mayoría de los casos del teatro occidental, implica estudiar una partitura escrita, el texto dramático. A esto nos referimos cuando hablamos de "asumir un papel", y es así como el cuerpo del actor vive el tránsito de la literatura al teatro.

En el enfrentamiento entre los discursos literario y escénico, no escapa al espectador atento el hecho de que hay más de un Infante Fernando frente a sus ojos durante una función: el del dramaturgo, el del director de la puesta en escena y el del actor. Estamos hablando de que, durante el espectáculo teatral, Calderón no es el único autor en juego.

A este respecto, hay que notar que un espectador teatral funciona como un lector en varios niveles, y que por ello es necesario ampliar la noción de texto para que abarque no sólo el concepto literario sino, también, todo aquello factible de ser decodificado, es decir, leído. En el caso específico del fenómeno teatral, semiólogos como Anne Ubersfeld, Patrice Pavis y Fernando del Toro han distinguido dos niveles esenciales: el Texto Dramático y el Texto Espectacular (el discurso escénico), con diferentes subniveles ${ }^{24}$, tal y como más arriba ya expusimos.

Aquí nos remitiremos a los dos niveles básicos mencionados para analizar el trabajo del actor como co-autor en el fenómeno teatral. Como Texto Dramático entenderemos entonces todo lo referente al carácter literario, es decir, a la puesta en papel de la obra

\footnotetext{
${ }^{24}$ Revisar especialmente De Toro, 1989. Semiótica del teatro: todo el capítulo II.
} 
teatral, y como Texto Espectacular asumiremos lo concerniente a la interpretación escénica, implicando ahí el discurso escénico del actor.

Si bien dejamos en claro que la actuación forma parte del Texto Espectacular, habrá que distinguirla cuando menos, para los fines de este estudio, como una sub-textualidad, más bien sub-discursividad. Pasando del nivel literario al del espectáculo, ¿qué tan autónomo puede ser el discurso o interpretación actoral, la actuación como texto, con respecto al Príncipe constante "original", el de Calderón? En el siguiente esquema ofrecemos un punto de partida para esta discusión intertextual.

\begin{tabular}{|c|c|c|}
\hline Texto A & Texto B & ¿ $=$ C? Discurso A' \\
\hline \multirow{5}{*}{$\begin{array}{c}\text { El príncipe constante } \\
\text { de Calderón de la Barca } \\
\text { Hipotexto dramático del... }\end{array}$} & & \\
\hline & $\begin{array}{l}\text {... Hipertexto espectacular } \\
\text { El príncipe constante }\end{array}$ & \\
\hline & $\begin{array}{c}\text { Puesta en escena } \\
\text { (adaptación dramatúrgica, } \\
\text { cuaderno de dirección, bitácora }\end{array}$ & \\
\hline & Hipotexto conceptual del... & \multirow{2}{*}{$\begin{array}{l}\text {...discurso escénico } \\
\text { interpretativo } \\
\text { El príncipe constante } \\
\text { Actuación }\end{array}$} \\
\hline & & \\
\hline
\end{tabular}

(Esquema intertextual: El príncipe constante.)

Hay que anotar que ya el texto de Calderón (el texto A) implica la reunión de autores anteriores que irían, cuando menos, desde João Alvares (por su Chronica dos feitos, vida e morte do Iffante [sic] sancto Dom Fernando que morreo em Feez) hasta Lope de Vega (por su primer tratamiento dramatúrgico del relato), sin olvidar las probables influencias, en lo filosófico y en la conformación del carácter de su personaje, de las Cartas de Séneca o, en cuanto a la estructura y estrategias de construcción dramática, del Arte nuevo, de Lope, así como del Tesoro de Covarrubias, la Philosophía antigua poética del Pinciano y el Diccionario de autoridades como referentes culturales generales. Con esto queremos proponer que, desde un punto de vista intertextual, la función de Calderón como autor 
germinal original de El príncipe constante, como la de cualquier autor bajo esta perspectiva intertextual, ya es de suyo relativa.

El análisis intertextual muestra cómo el proceso de la puesta en escena (el texto B y el discurso A') diluye la participación de Calderón en tanto que autor literario al transitar por las interpretaciones de una adaptación dramatúrgica, de la concepción escénica de un director y de la hermenéutica personal del actor, mismas que se suman para volver su guión original una creación colectiva. Lo curioso es que no parece suceder lo mismo con su función autoral, que más bien se ve agrandada y fortalecida, pues todo el background cultural que sintetiza Calderón no habla de otra cosa sino de su capacidad para recontextualizarse en la historia. En otras palabras: a pesar de la impronta creativa de adaptadores, directores de escena y actores, en cada nuevo hiper-texto o discurso escénico nadie le negará el crédito de autoría original a Pedro Calderón ("Yo adapté, yo dirigí, yo actué El príncipe constante DE CALDERÓN"). Incluso parte del goce estético de lectores, ejecutantes escénicos y espectadores ha de consistir en una compleja fascinación por la imperecedera trascendencia de su obra. Este fenómeno lo ha explicado Walter Benjamin en La obra de arte en la era de la reproducción mecánica al constatar la permanencia de cierta unicidad o cualidad única e irrepetible de las obras de arte incluso ante su multiplicación industrial en los mass media. Benjamin llama a esta cualidad aura.

Puesto que es claro que el aura de un poeta como Calderón perdura allende la representación de sus obras, no procede, por lo tanto, temer a la inclusión de las demás creatividades teatrales (adaptadores, directores, escenógrafos, músicos, actores, etc.) en la evolución de la obra dramática entre su fase como literatura y la del fenómeno escénico. Antes es mejor alentarla, pues entre mayor es la participación de los lectores intérpretes, más sofisticada se vuelve la obra misma, al multiplicarse claramente su glosa y su goce.

Vale la pena asimismo analizar no sólo cómo lee un actor, esto por tratarse de uno de los lectores más especializados, si no el que más, en lo que a leer drama respecta, y quien hoy por hoy puede ofrecer una genuina perspectiva filológica original, sino cooperar con él para que lea cada vez mejor y, luego entonces, su discurso A' proyecte tanto la obra original de Calderón como un Príncipe constante profundamente personal, explicitando así una condición ya observada por la estética de la recepción: que es el lector quien aporta el 
sentido último de una obra artística, su interpretación definitiva (al menos hasta ese momento).

\section{Análisis actancial del texto dramático}

Necesitamos un modelo de análisis del texto dramático con propósitos más especializados para la representación, es decir, para lo que los actores denominamos, durante el proceso de montaje, un "trabajo de mesa." Un trabajo de mesa no es solamente un análisis teóricoliterario. Desde luego, son aspectos importantes el contexto cultural de producción del texto dramático y un acercamiento a la forma y/o la estructura dramática, incluyendo el subgénero dramático. Sin embargo, lo que al actor más le preocupa es entender la historia y los personajes, especialmente su propio personaje, por supuesto, de forma tal que pueda proyectarlos en escena. Una herramienta que permite acercarnos simultáneamente a estos dos elementos del texto (la historia y los personajes) es el análisis actancial. En las siguientes líneas veremos un enfoque novedoso para este tipo de análisis, pensado para la utilidad inmediata, o sea representacional, de los actores. Si Don Pedro Calderón escribía para la escena, entonces sus lectores ideales eran desde luego los actores, quienes recibían cada uno un papel para armar, colectivamente, el gran discurso espectacular, su fin último. En el debate sobre la naturaleza de la literatura dramática, eso es un voto por ligar su textualidad a la representación teatral, es decir, por ver en la dramaturgia su cualidad de partitura por encima de otras posibilidades de lectura.

Con el fin de fortalecer ese nivel de acercamiento al texto dramático, consciente de su parcialidad mientras no se consuma el fenómeno escénico, intentaremos articular una herramienta de lectura pensando en el actor, de modo que se le facilite al mismo entender la participación de cada personaje en un relato teatral y construir enseguida una interpretación escénica más sólida. Esta herramienta se apoya en el concepto del actante, diferenciada de la del actor:

Actante es el elemento de una estructura sintáctica que puede ser común a muchos textos. Es una entidad general, no antropomorfa y no figurativa: el Amor, el Odio, la Ciudad, el Poder, el Feudalismo, la Ley, etcétera. Tiene solamente una existencia teórica y lógica en el sistema de acción. 
Actor (tomado del término francés acteur, el que actúa) es una entidad antropomorfa e individualizada, caracterizada por un conjunto de acciones concretas, que podríamos equiparar al personaje en el sentido tradicional.

(Norma Román Calvo, El modelo actancial y su aplicación, 88.)

Norma Román señala la diferencia entre la función sintáctica y la función actoral, ambas presentes en el fenómeno teatral, y hace un estudio sobre el modelo actancial de análisis del texto dramático y su aplicación. Sobre este modelo, se indica:

Éste es, didáctica y pedagógicamente, un valioso instrumento de análisis y reflexión para los estudiosos del texto dramático, a quienes les será de gran utilidad, gracias a su acercamiento riguroso, científico, que se aparta del todo de la subjetividad y superficialidad generalmente adoptados en la lectura de textos específicamente teatrales. (Armando Partida, "Presentación", en Román Calvo: El modelo actancial y su aplicación, 7.)

Contra algunos señalamientos de que el modelo actancial es extremadamente esquemático, reduccionista y, por lo tanto, superficial y falto de complejidad, Norma Román argumenta: "[...] con la aplicación del modelo actancial es posible llegar al nivel más profundo de una obra y encontrar ahí las fuerzas que mueven la acción dramática" (El modelo actancial y su aplicación, 11.)

Queremos proponer un enfoque particular de análisis del texto dramático con base en los modelos actanciales, observando que, precisamente por sus posibles limitantes, es importante revisarlos y actualizarlos con el fin de que su utilidad para los estudiosos, los directores y-sobre todo- los actores que los aplican y promueven, crezca.

Algirdas Julien Greimas (1971, Semántica estructural) planteó un modelo de análisis semiológico, aplicable a microuniversos míticos o socioculturales, como el teatro, a partir de los estudios de Vladimir Propp (Morfologija skasky, traducida al francés en 1970) y Ètienne Souriau (1950, Les 200.000 Situations dramatiques), basado en esferas de significación de acuerdo con las funciones de los elementos o personajes involucrados. El sistema de Greimas permite hacer así una reducción del relato dramático convencional a sus elementos semánticos mínimos. El sistema explicita los hilos que componen la textura dramatúrgica. Se trata de las funciones actanciales o actantes. Según este modelo, existen los seis siguientes actantes: 
1.Sujeto: El protagonista o héroe. Fuerza temática orientada, agente que ejecuta la acción-base del relato analizado para alcanzar un objeto buscado, deseado o amado.

2.Objeto: Bien, personaje o valor orientador que, siendo buscado, deseado o amado por el sujeto, da propósito al relato analizado (un talismán, un tesoro escondido, el amor, la felicidad, la venganza.)

3.Destinador: (donnor o provider) Fuerza orientadora. Donador o proveedor del bien u objeto deseado, convoca al sujeto a ejecutar sus acciones. Puede suponer divinidad, destino, azar, pasión, arbitrio o voluntad superior.

4.Destinatario: Quien obtiene virtualmente el objeto, bien, consecuencias o efectos finales del entramado de sucesos, como el vicioso que es castigado, la pareja unida por fin, el padre vengado, etc.

5.Oponente: Fuerza contraria al sujeto en su búsqueda del objeto. El, o los, antagonistas. También pueden ser simplemente circunstancias adversas al sujeto (una tormenta, un terremoto, un quiebre bursátil.)

6.Ayudante (traducido como "adyuvante" en casi todas las ediciones): Fuerza auxiliadora o colaboradora del sujeto, como serían un amigo, un sirviente, un ejército, un arma, un aviso, un mecenas o una circunstancia favorable.

Cada actante o función actancial cumple, como vemos, una función específica. Cada función puede ser ocupada por uno o varios personajes o circunstancias, puesto que el modelo no analiza en este nivel individualidades, sino esferas de acción. Todos se ordenan según el esquema siguiente, ideado por el propio Greimas:

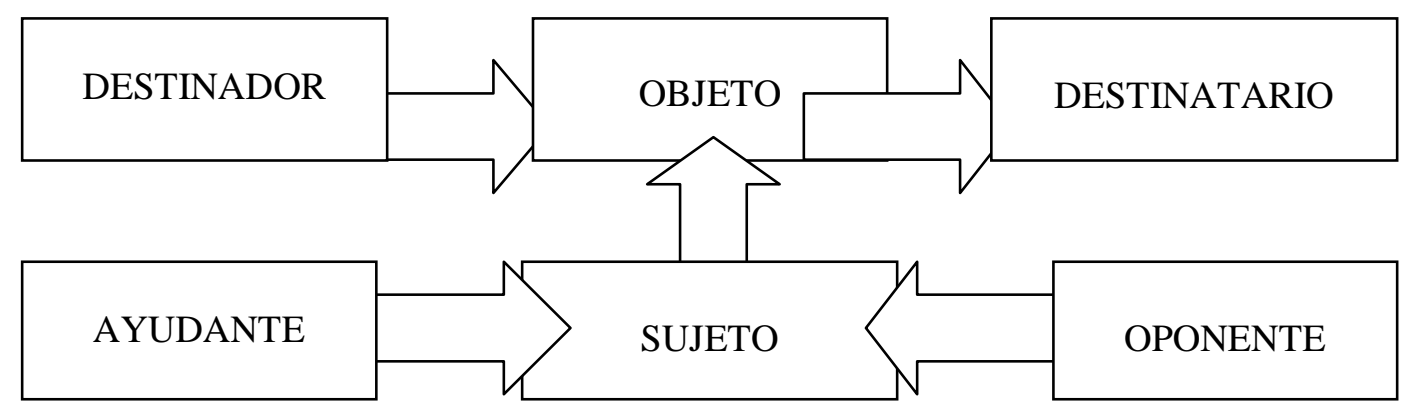

(Esquema 1: Análisis actancial de Greimas.) 
En este esquema la categoría del sujeto no aparece tan fuerte como los personajes que involucra, que serían el o los protagonistas. La flecha que relaciona al sujeto con el objeto recibe el nombre especial de línea del deseo. Este esquema se centra precisamente en el objeto de deseo, lo cual tiene sus ventajas al colocar a este actante como objeto de comunicación entre el destinador y el destinatario. La posible inconveniencia del esquema, radica, pues, en la subordinación del sujeto. La acción del sujeto no nos parece tan simple como para ubicar a esta fuerza actancial en un plano visual inferior, pues semánticamente se reduce su importancia. El esquema, por lo tanto, pierde interés y hasta credibilidad. Si consideramos que el propósito de Greimas es hacer de su modelo "la extrapolación de la estructura sintáctica" (Greimas 1971: 284), acaso convendría más replantear la posición de los actantes y, especialmente, la del Sujeto.

Anne Ubersfeld (1989, Semiótica teatral) propone una modificación al modelo actancial que puede dedicarse específicamente al relato dramático. Ella coloca al sujeto entre el destinador y el destinatario y al objeto entre el ayudante y el oponente, con la intención de presentar al objeto como centro de un conflicto.

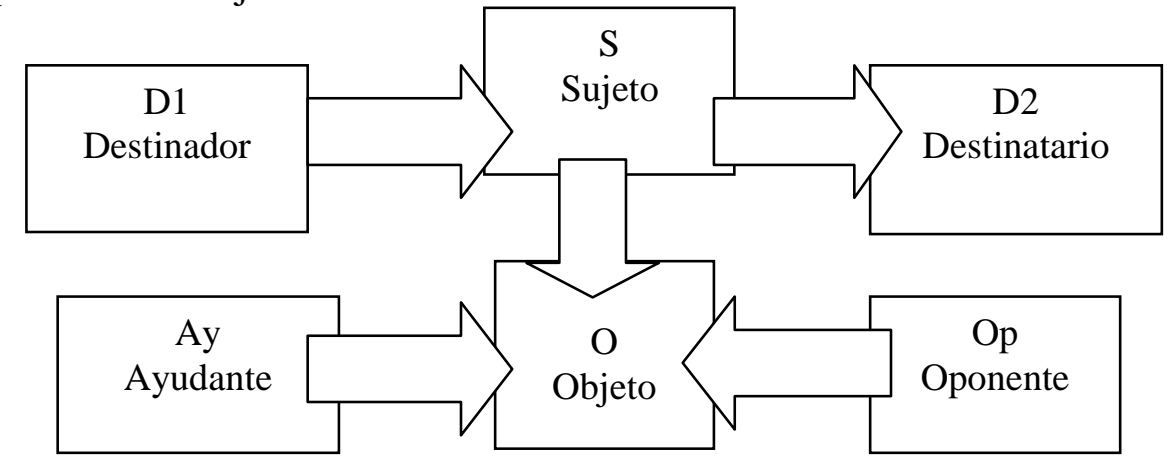

(Esquema 2: Modelo actancial de Ubersfeld para el texto dramático.)

La mayor virtud de esta propuesta es que aumenta visualmente la importancia del sujeto. Norma Román Calvo enriquece la propuesta de Ubersfeld:

Después de haber trabajado durante varios años con el diagrama del modelo actancial, hemos observado que [...] todo relato es la historia de un personaje que desea algo con toda su fuerza, y que [...] a través de la historia, el sujeto realiza una serie de acciones tendientes a obtener ese objeto, [sin embargo, en contraste] la flecha que señala ese movimiento, del sujeto hacia el objeto, está colocada en posición vertical [en el modelo de Ubersfeld], lo que, visualmente, produce una sensación de rigidez. Por esta razón y para que se tenga una imagen de aparente movimiento es más conveniente dibujar una línea diagonal 
entre el sujeto y el objeto. (2007 El modelo actancial y su aplicación, 58. Ver también: 2001 Para leer un texto dramático, 42 y 43, de la misma autora.)

La aportación también agrega dibujar más intensamente (en negro) esta flecha del deseo (entre el sujeto y el objeto), considerada por Román Calvo como el eje básico de todo relato dramático, todo para mostrar: "más claridad respecto a los movimientos de las fuerzas" (Román Calvo 2001: 43.) El esquema del modelo propuesto por Román Calvo queda así:

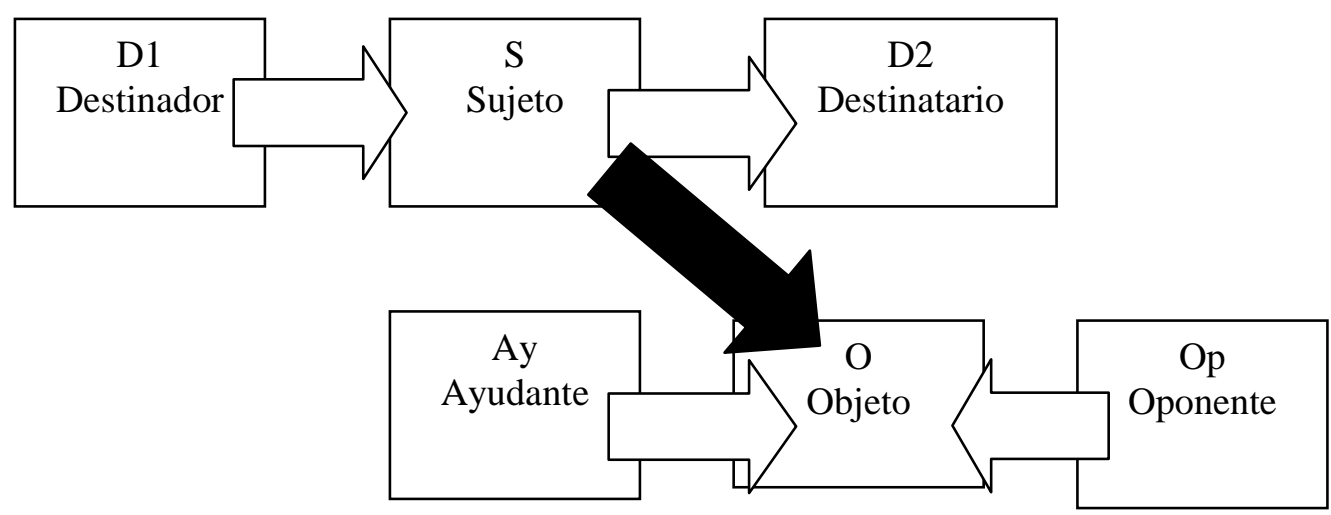

(Esquema 3: Modelo actancial según Román Calvo.)

El énfasis en la flecha del deseo es toda la aportación de Román Calvo. Al conseguir Ubersfeld el realce logrado para el sujeto, y Román Calvo la reafirmación de la línea de acción y del deseo, se obtiene que: "La aplicación del modelo actancial revela y esclarece los problemas de la acción dramática, así como las causas de la resolución de los conflictos o no resolución de los mismos." (Román Calvo. El modelo actancial y su aplicación, 197.)

El estudio, aplicación constante y mejoras hechas por Norma Román al modelo actancial en su experiencia como dramaturga, como crítica teatral y en su tesis doctoral, le han permitido concluir que: “A partir de la manifestación del cuadro general (o cuadros generales) es posible enunciar la acción dramática, esto es, lograr la reducción del desarrollo de la acción a su extrema sencillez; es decir, a un esquema puro." (El modelo actancial y su aplicación, 199.)

La reducción no significa una simplificación si vemos cómo los ejemplos de Román Calvo en su aplicación del modelo exponen no sólo la esencia del relato, en la forma de una “gran oración”, sino también descubren la estructura dramática, posibilitan el cálculo de la proyección del tiempo, el ritmo e intensidad de la representación escénica, y muestran la 
causalidad, conflictiva, temática e ideología latentes en los textos. De modo importante para los actores, además, el modelo encamina en la búsqueda de la psicología y motivaciones de los personajes.

Ubersfeld y Román Calvo coinciden en que para el caso de una obra compleja, como por ejemplo en nuestro caso El príncipe constante, pueden desarrollarse esquemas múltiples: secuencias actanciales, ya sea por los cambios en el ejercicio de la voluntad, del objeto de deseo, de las motivaciones destinadoras, o bien, por ubicar la perspectiva del análisis sobre otro personaje como sujeto actancial del relato.

A pesar de todas estas virtudes y posibilidades halladas por Norma Román, en este trabajo nosotros pretendemos, sin embargo, una variante más crítica.

\section{Propuesta del modelo Dramema}

Pensando en el ojo del lector, se propone que el esquema sea más claro ubicando al destinador por arriba de todas las demás fuerzas, como aquella que detona la acción señalando el camino al protagonista(s), así como dejando hasta el último, en el extremo inferior, al receptor final de todo el entramado de sucesos. Enseguida, se coloca al sujeto al mismo nivel horizontal del objeto, en una relación causal y dinámica sobre la línea de deseo que los une. Finalmente, hay que poner al ayudante del mismo lado que el sujeto, aunque en un orden inferior, abajo, con una sola flecha bicéfala que ilustre mejor su tensión con el oponente, haciendo quedar a éste, además, del lado del objeto, como una fuerza claramente antagonista del sujeto. Para diferenciar nominalmente esta variante radical del análisis actancial proponemos el nombre provisional de dramema.

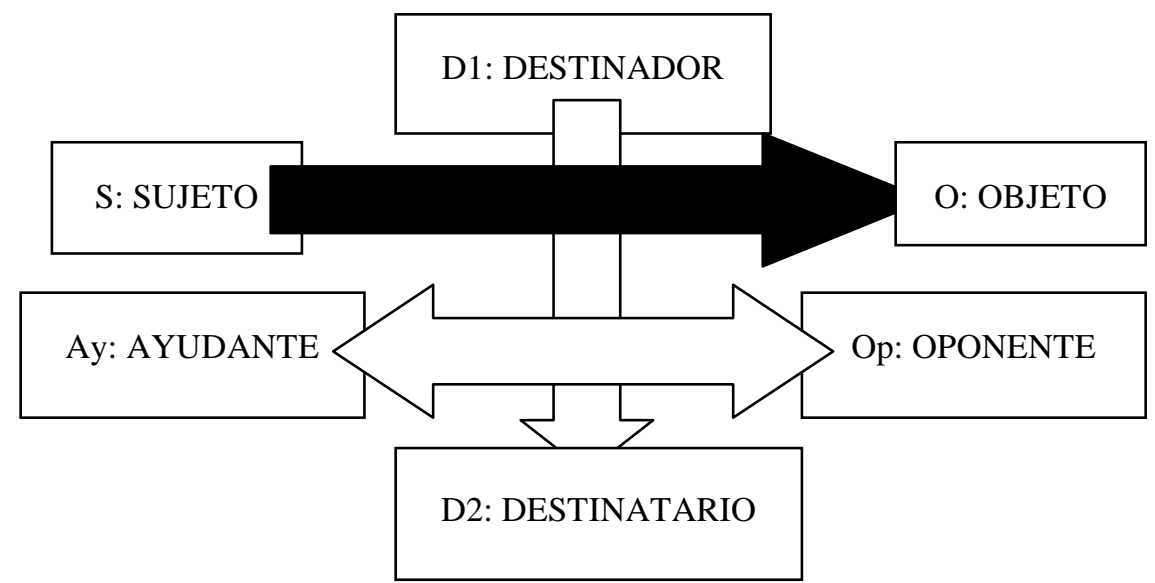

(Esquema 4: Modelo actancial Dramema.) 
El simple cambio de orden visual altera el sentido del sistema. De ahí que lo consideremos más que un simple matiz, un nuevo modelo de análisis con base en las funciones actanciales. No cambia, sin embargo, la intención fundamental de Greimas (acaso se afina), que es ordenar las fuerzas que interactúan en el relato. Como en un enunciado u oración, el sujeto se aprecia en una conexión coherente con el objeto: Sujeto+Verbo+Objeto. ${ }^{25}$ El verbo de acción de este enunciado actancial es buscar (pues es la función semántica manifestada, según el propio Greimas 1971: 277.) Este enunciado actancial expresa la síntesis argumental del relato dramático. Su presentación más sencilla quedaría así: <<A busca $\mathrm{B} \gg>$. El resto de funciones actanciales (ayudante, oponente, destinador $\mathrm{y}$ destinatario) equivalen sintácticamente a complementos circunstanciales del enunciado elemental, y podemos llamarlas así: actantes circunstanciales.

Es importante reconocer que este modelo de análisis es limitado y parcial, por lo que su uso sólo es pertinente si se toma como punto de partida o referencia para un estudio literario o teatral más profundo, como es el caso del nivel interpretativo del actor: "La mejor actuación se logra con base en la comprensión profunda de la situación ficticia." (Braulio Peralta, "De la naturaleza del histrión", 17.) Tal es lo que intentaremos con El príncipe constante de Calderón.

Para conseguirlo, vale la pena observar una correspondencia entre el Objeto de deseo como fuerza actancial y el objetivo o tarea en el sistema de acciones físicas de Stanislavsky. Siguiendo Un actor se prepara y La construcción del personaje, del maestro del Teatro de Arte de Moscú, baste decir que en la línea de pensamiento que estimula la vida interna del actor al interpretar su personaje la obra es dividida en unidades de acción, donde en cada unidad el personaje debe cumplir una tarea, misma que para el actor se vuelve una tarea escénica, significada por un objetivo. En la práctica, el objetivo se traduce en acciones físicas, es decir, en la vida animada de los personajes ya en la escena: el espectáculo. Es importante ver entonces la importancia que tiene para el actor una lectura del texto dramático que facilite la ubicación de ese objetivo. Para ponderar si el análisis actancial puede ser esa herramienta, tenemos que pasar por confirmar que puede

\footnotetext{
${ }^{25}$ Justamente Helena Beristáin homologa los actantes de Greimas a categorías funcionales gramaticales (1982, Análisis estructural del relato literario: 74.) También José Amezcua, haciendo eco de Luisa Puig (La estructura del relato y los conceptos de actante y función. México: UNAM, 1978) y de Michael Issacharoff ("Drama and the Reader" [reseña sobre Lire le thèâtre], Poetics today, 2: 1981, núm. 3, 255-263) sintetiza: "La clasificación actancial greimasiana se basa en la premisa de que un texto narrativo [o dramático] equivale a una oración y, por tanto, es susceptible de ser analizado por el procedimiento gramatical con el que se estudia la oración." (Lectura ideológica de Calderón. 107.)
} 
establecerse una relación directa (que no una equivalencia) entre el objetivo en el sistema Stanislavsky y el objeto actancial, así como entre el personaje (protagonista en este caso) y el sujeto. Es lo que aquí indagaremos.

\section{Argumento}

Aunque el manuscrito de 1629, la primera edición de 1636 y la reedición de 1640 de El príncipe constante difieren en diversos aspectos, mismos que comentaremos a detalle en el capítulo VI, ${ }^{26}$ podemos fijar el argumento básico-fundamental como sigue:

Durante una de las últimas aventuras de la Reconquista cristiana de la península ibérica, ocupada por el Islam desde el siglo VIII, el general musulmán Muley de Fez se presenta ante el rey de los moros para advertir de la llegada de una armada fabulosa a las costas del noroeste africano. La expedición es encabezada por Fernando, príncipe de Portugal, quien viaja con su hermano Enrique (conocido históricamente como El Navegante) para arrebatarles Tánger y liberar a los prisioneros de guerra. Al principio la contienda parece favorecer a los europeos, tanto así que Fernando se permite perdonar la vida y la libertad al caído Muley para que pueda pedir la mano de la princesa Fénix, hija del Rey Moro. Sin embargo, la impronta de las tropas del general Tarundante de Marruecos (y quien además pretende a Fénix con el favor de su padre) propicia que Fernando caiga preso.

La posición de infante que tiene Fernando hace que sea muy bien valorado como pieza de rescate. Así, para liberar al príncipe los musulmanes demandan Ceuta, bastión estratégico (al sur del Estrecho de Gibraltar y una de las dos columnas de Hércules que abren el Mediterráneo al océano Atlántico). Enrique vuelve entonces con la aceptación del agonizante rey portugués Duarte de devolver Ceuta a los moros. Sin embargo, Fernando rechaza y destruye el bando de su difunto hermano Duarte, aun cuando viene respaldado por el monarca heredero Alfonso, arguyendo que no debe dejarse perder esa ciudad, ahora cristiana, aunque ello implique acompañar a sus compatriotas presos en el más indigno cautiverio.

El Rey Moro, quien hasta entonces ha tratado con nobleza a Fernando, lo esclaviza sin que nada puedan hacer Enrique ni Muley. Fernando muere cautivo en Fez. Pero

\footnotetext{
${ }^{26}$ En el capítulo VI realizamos una adaptación con fines representacionales con base en un análisis arqueofilológico que, comparando sus dos primeras versiones (1629 y 1636), respetara las intenciones esenciales del dramaturgo original, reflejara el contexto histórico-cultural, cuidara la verosimilitud y coherencia de la historia y buscara la claridad de la trama. No consideramos la edición de 1640 por propiciar una confusión entre los personajes de Muley y el Rey de Fez.
} 
entonces su espíritu aparece para guiar a las tropas portuguesas en una nueva campaña de la que por fin salen victoriosas. Enseguida los moros, ya sometidos, entregan el cadáver de Fernando a los suyos, liberan a los prisioneros sobrevivientes y, adicionalmente, aceptan el desposorio de Muley con Fénix.

\section{Análisis estructural de $\mathrm{El}$ príncipe constante}

Buscando las funciones actanciales, en beneficio de clarificar para la puesta en escena cuáles son los personajes más determinantes para el desarrollo del conflicto dramático, qué tareas escénicas cumplen y cuál es el significado de esas tareas (pero cuidando no equiparar actante con personaje), se encuentra que el protagonista de la obra es el Príncipe Fernando de Portugal, puesto que es el agente que mueve la acción del relato dramático: encabeza la campaña de Tánger, perdona y libera a Muley, rechaza su propio rescate por Ceuta, motiva su cautiverio, esclavitud, muerte, y luego ya fallecido guía de nuevo a sus compatriotas hacia la victoria final. Por lo tanto, es el correspondiente Sujeto para el análisis actancial. Tampoco parece implicar mayor dificultad determinar el Destinador, es decir, la fuerza orientadora del Sujeto. Ésta es la ocasión para distinguir con claridad entre fuerzas actanciales y personajes, pues en El príncipe constante es evidente que la fuerza que guía a Fernando no es precisamente el rey (primero su hermano Duarte y luego su sobrino Alfonso), ni su patria Portugal, ni el amor de una dama ${ }^{27}$, es decir, no es un personaje (ni individual ni colectivo), sino su fe cristiana. A partir de la fe, Fernando despliega su voluntad en distintos objetivos, los que acomete como tareas por cumplir y que se ejecutan como acciones sucesivas. Siguiendo a Ubersfeld y a Román Calvo, conviene dividir el argumento de la obra en secuencias, en este caso de acuerdo con la evolución de las aspiraciones (deseos) del protagonista, en correspondencia con la evolución semántica de Fernando como fuerza actancial (que busca y ejecuta). Esto permitirá definir el o los distintos Objetos de deseo, mismos que para un actor constituyen los objetivos o tareas.

1.El primer objeto de deseo Fernando es la conquista de Tánger.

\footnotetext{
${ }^{27}$ Hay varias mujeres en la obra: Fénix, Rosa, Zara y Celín, de las que sólo Fénix, por su belleza e hidalguía, es significativa para Fernando. Rosa y Zara sólo enmarcan y resaltan la presencia, como damas de compañía, de Fénix. Sin embargo, al confirmar él que se trata de la amada de Muley, en una muestra de generoso sacrificio (entre muchas otras virtudes que despliega en toda la obra), renuncia a ella.
} 


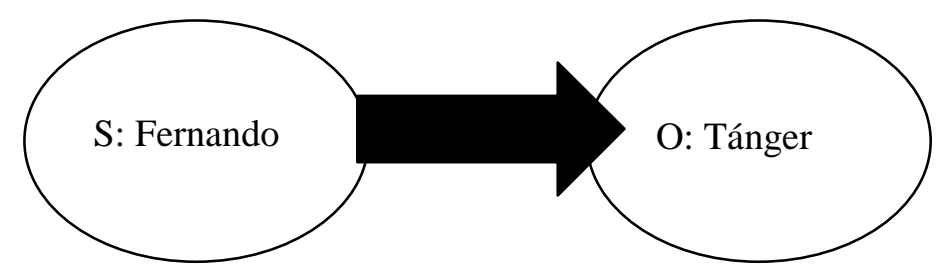

(Esquema 5)

2.El segundo objeto de deseo del infante portugués, al caer preso, es desde luego recuperar la libertad, bien merecida además por su nobleza y heroísmo en una guerra donde ha combatido limpiamente, con honor y hasta con generosidad (al dejar con vida y en libertad a Muley).

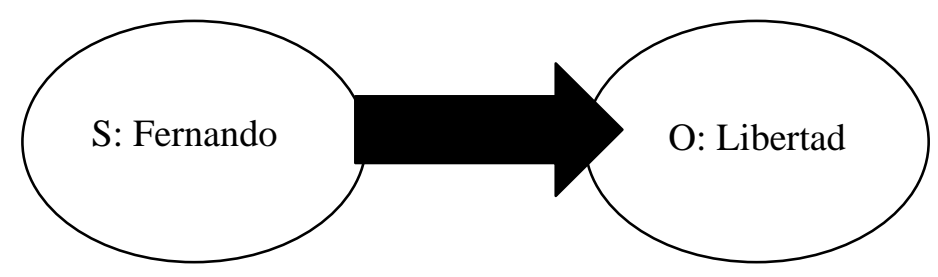

(Esquema 6)

3.El tercer objeto de deseo del príncipe de Portugal es impedir la toma de Ceuta por los moros, defendiéndola primero a costa de su ansiada liberación y luego de su vida misma.

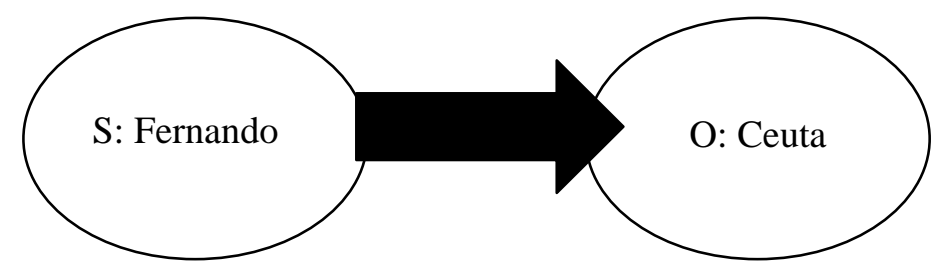

(Esquema 7)

4.Más allá de la muerte, el cuarto objeto de deseo del guerrero lusitano vuelve a ser la defensa de la cristiandad, la victoria de Portugal sobre los moros y el rescate de los rehenes sobrevivientes, orientando a los soldados y animándolos hasta la entrega de su propio cuerpo fallecido.

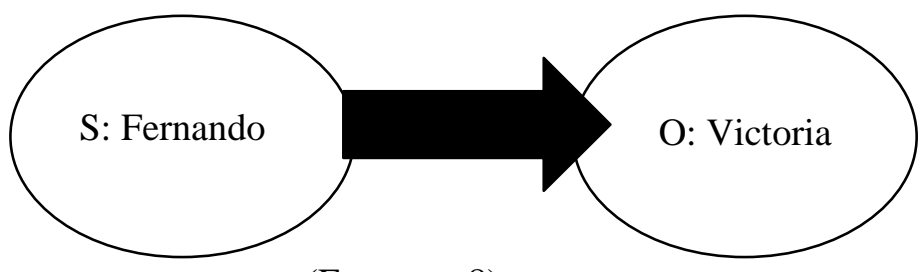

(Esquema 8) 
5.Un quinto objeto de deseo de Fernando, no precisamente en orden cronológico, es ayudar al moro Muley en su propio propósito de desposar a Fénix, perdonándole la vida y concediéndole la libertad en plena batalla para que pueda poner en orden sus pasiones y darles feliz resolución. Ello atraviesa el propio esquema actancial de Muley, atormentado por los celos de perder a Fénix en un matrimonio arreglado con el rey Tarundante, en parte como consecuencia de mantener en secreto su verdadero amor. Como otro triunfo de Fernando, y para fortuna de Muley, uno de los tributos de guerra será la concesión de su boda con Fénix.

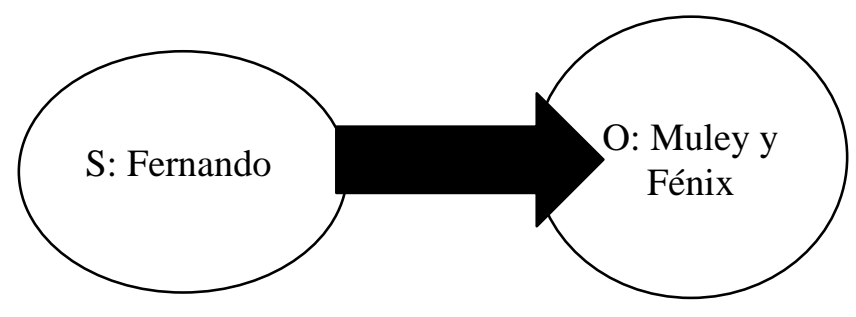

(Esquema 9)

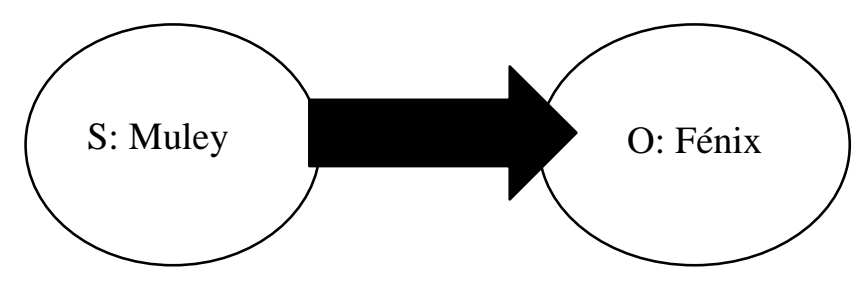

(Esquema 10)

Todos los objetos de deseo arriba enunciados pueden, sin embargo, resumirse en uno solo, que ahora mismo explicamos. Dado que el carácter más visible de Fernando es el ser virtuoso, podemos decir que es ésta la definición de su ser, es decir, el significado de su existencia: ser santo. Por lo tanto, hay que buscar su función semántica en las aplicaciones de esa virtud. En este sentido, podemos apreciar que sistemáticamente Fernando aplica toda su capacidad, sus virtudes, a la defensa no sólo material, sino también moral y espiritual de la fe católica. ${ }^{28}$

\footnotetext{
${ }^{28}$ Todo esto, recordemos, desde la perspectiva católica y por cierto contrarreformista de Calderón, para quien los acontecimientos dramatizados, incluso el milagro de la aparición fantasmal de Fernando, eran hechos
} 
Esto amplifica el alcance de su voluntad. Si Fernando no puede ganar la guerra, como planea al inicio del drama, entonces -preso- esperará un momento más oportuno, en una futura campaña, mientras entrena (en la penitencia del cautiverio) su espíritu religioso superponiéndolo a su cuerpo guerrero. Fernando no indica pretender otra cosa, y su mismo deseo de libertad es un mero trámite hacia ese propósito, buscando liberar a sus soldados y a sí mismo con la seguridad de mantenerse dentro del plan prescrito por Dios.

Al ver, empero, condicionada su libertad a la entrega de Ceuta, el objetivo principal de la victoria material sobre los enemigos de la fe se matiza en la variante de impedir que ellos ganen, reduciendo de momento el alcance del triunfo total a una pequeña victoria moral, pero victoria al fin. Fernando se asegura que Ceuta no sea entregada al destruir él mismo el decreto signado por dos reyes (Duarte y Alfonso) que autorizan el rescate, aunque ello implique categóricamente su condena a muerte. Y muere, desde luego.

Una vez muerto, y en total concordancia con una perspectiva absolutamente católica, Fernando ya no tiene ataduras materiales para asegurar su propósito: la derrota de los moros: el triunfo sobre los infieles: la victoria de la fe. (Milagro póstumo no sólo de valor hagiográfico, sino además de un peso político capaz de motivar multitudes para ganar, como con Santiago Matamoros, batallas y guerras.) Esto, por cierto, lo consigue con la ganancia adicional del matrimonio de Muley con Fénix, lo cual implica una clarísima derrota moral del programa político, religioso y personal de un monarca que en el drama original de Calderón sólo recibe el nombre de "Rey Moro".

La síntesis argumental del relato dramático de El príncipe constante quedaría expresada en el siguiente esquema actancial:

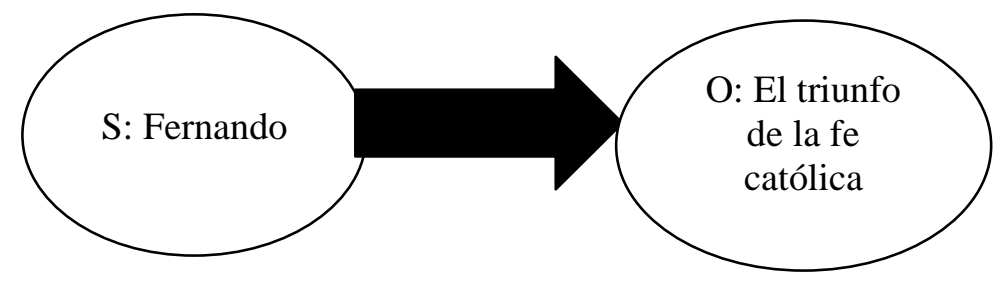

(Esquema 11)

Podemos ahora agregar los actantes circunstanciales: El Destinador (D1), ya lo establecimos, es la fe católica. Al Príncipe le ayudarán (Ay), por una parte, sus virtudes, 
que prácticamente hacen de él un santo cristiano; por otra parte, su compañero incondicional don Juan; sus hermanos Enrique y los reyes Duarte y Alfonso; el príncipe moro Muley; y los soldados y los cautivos portugueses. Desde luego, su antagonista es el Rey Moro (Op), representante del Islam, apoyado formalmente por Muley, el rey Tarundante y los soldados musulmanes. Finalmente, los beneficiarios (D2) serán los cristianos en general -la fe católica- y, en orden de particularidad, la corona, los soldados y los cautivos portugueses, y Fénix y Muley, sin omitir como afectado -en su muerte- al mismo Fernando (a quien la iglesia por cierto luego declaró santo).

El enunciado actancial integrado se desglosa así:

Por inspiración de su fe católica, el infante don Fernando, príncipe de Portugal y maestre de la orden católica de caballería de Avis, intenta arrebatar el puerto de Tánger a los moros con la ayuda de su hermano Enrique el navegante, los soldados lusitanos y sus virtudes cristianas; pero cayendo preso -y al no aceptar su rescate con la entrega de la estratégica ciudad de Ceuta- es maltratado hasta morir, defendiendo con su vida la fe cristiana; aunque después de muerto logra su victoria y los beneficiarios resultan, finalmente, la fe católica, los portugueses, y los amantes moros Fénix y Muley.

El esquema completo, con nuestra versión del análisis actancial, resulta así:

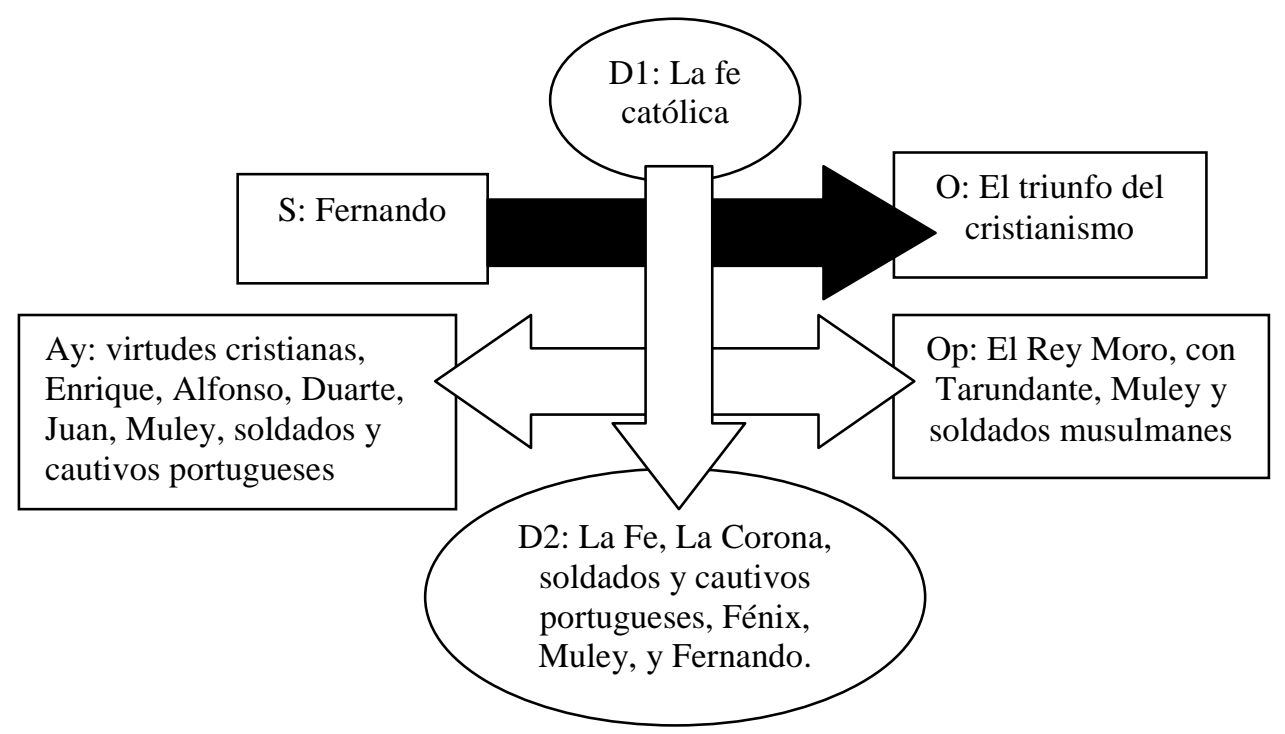

(Esquema 12: Análisis actancial de El príncipe constante, aplicando el modelo Dramema.) 
El análisis actancial, especialmente al definir la síntesis argumental, facilita una eventual adaptación dramatúrgica $^{29}$ al seleccionar las principales líneas de acción, y clarifica el trabajo de los actores mediante la exposición de sus funciones dentro de la historia. También ofrece un enfoque original para enriquecer el estudio de la literatura dramática y sentar las bases para un acercamiento diversificado al sistema de signos teatrales.

Respecto a la utilidad del análisis dramema en el trabajo de los actores, no es difícil encontrar una descripción sencilla de sus funciones escénicas:

1.El intérprete de Don Enrique puede concentrarse en ir por detrás de su hermano Fernando, secundando con pequeñas variantes o matices sus objetivos, tanto en la campaña por Tánger como en la defensa de Ceuta, como en la última batalla ya muerto aquel. Sus pequeños conflictos interiores pueden ser gratamente interpretados, como sus premoniciones al inicio de la guerra, su dolor al abandonar a Fernando dos veces, sus sendos lutos por Duarte y por Fernando mismo, y su nobleza en la victoria.

2.Don Juan de Silva tiene como tarea primordial apoyar y acompañar a Fernando en todo. En este sentido, no tiene ningún conflicto interior.

3.Muley y Fénix viven su propio drama dentro del de Fernando. Aparentemente no podían faltar los temas recurrentes del amor, los celos y el enredo, típicos de la literatura barroca. Su historia sin duda ennoblece y embellece aún más la de Fernando, aunque es claro que no es la diégesis toral.

4.Don Alfonso prácticamente puede llegar al final y decir: "Ahora el Maghreb me pertenece, gracias." (No lo dice en la obra como tal, pero lo puede asumir el actor como una actitud en su interpretación.)

5.Los cautivos de guerra están destinados a hacer de coro trágico de la condición de Don Fernando. Aunque de hecho abren la obra, no aparecen en la lista de dramatis personae (aunque se consideren implícitos entre los soldados).

\footnotetext{
${ }^{29}$ Muy útil si se considera la extensión total de un texto como El príncipe constante para una audiencia contemporánea, de cultura más audiovisual que literaria. Más allá de la crítica humanística, habría que considerar que una puesta en escena en nuestros días debería de acercar el teatro clásico al público, en vez de agrandar el distanciamiento hoy existente y en vista de que la mayoría del público no estará precisamente ansiosa por acercarse a una obra extensa sólo por ser del siglo XVII. De acuerdo con nuestro estudio, algo similar haría Calderón al acomodarse a las circunstancias particulares de representación (ver capítulo I).
} 
6.Los soldados de ambos bandos son adyuvantes colectivos. Su función está definida según el bando correspondiente: adyuvantes $\mathrm{u}$ oponentes del protagonista lusitano.

7.Rosa, Zara y Celín son comparsas que sirven para presentar y conocer los pensamientos y sentimientos de Fénix. Celín en concreto ni siquiera es mencionada entre los dramatis personae y es usada sólo como vocero comodín de la corte musulmana, incluso pareciera un recurso particular (como una nota) de Calderón ante alguna condición representacional emergente (nótense las diferencias entre las versiones de 1629 y 1636).

8.En los contextos culturales posteriores del romanticismo decimonónico y la vanguardia del siglo XX, Goethe y Grotowski, respectivamente, intervienen el texto original al preferir prescindir de Brito o Coutiño, el gracioso (el nombre varía entre 1629 y 1636), cuya conducta es más bien pragmática y obra de modo independiente a todos los demás personajes, sin influir a favor o en contra de ninguno. Se puede inferir que su verdadera función es de contrapeso a las intensas emociones que vive el espectador durante el desarrollo de la obra, lo cual lo reduce aún más a ser un mero recurso escénico no indispensable para la anécdota. Se entiende que la decisión de los directores mencionados obedece a puros motivos representacionales con respecto a sus respectivos programas estéticos. Por otra parte, sin personajes como Brito se defiende mejor la tesis de Parker de leer en ciertas obras de Calderón -como ésta- no precisamente comedias (en estricto sentido), sino grandiosas tragedias (esencia habitante de mucha de la comedia nueva). De cualquier forma, ya el hecho de estar discutiendo el asunto habla de su respetable importancia. (Aclararemos más adelante qué tanto la perspectiva de Parker abona a nuestra particular lectura de El príncipe constante.)

9.Don Fernando, o sea su intérprete, puede dedicarse a buscar la victoria suprema, a manifestar ese deseo y a realizarlo de la forma más refinada posible. A pesar de las derrotas, sinsabores y amarguras que acometen al personaje, finalmente la victoria más allá de la vida terrenal es su propósito, y a través de su voz y su gesto fluyen transparentes sus meditaciones y acciones. 
No se trata de simplificar el texto de El príncipe constante, sino de sentar bases a partir de las cuales los actores puedan comenzar su exploración de los personajes y, entonces sí, escarbar tan profundamente como el concepto de puesta en escena (planteado casi siempre con el director) y su interés se los permita. Insistimos en que este análisis elemental no es el punto de llegada, sino apenas el de partida.

Hay obras del repertorio clásico que contienen elementos que trascienden la época en que desarrollan sus historias, de la misma manera como hay textos de nacionalidades culturalmente distantes de la nuestra que pueden reflejar eficazmente los conflictos que caracterizan a la comunidad en que vivimos. Esto nos demuestra que no debemos conformarnos con la superficie de la historia que nos narra un autor, sino que deberemos encontrar su esencia. (Carlos Padrón Montoya, "La puesta en escena a partir de un texto dramático", 61.)

Acabamos de ver cómo plantear una línea general de pensamiento-acción que oriente, como punto de partida, el trabajo del actor. Definimos así que, en principio, el intérprete de Fernando ha de buscar el triunfo de la religión católica por sobre los moros. Ahora rebasaremos ese punto de partida para ahondar en el espíritu profundo de la obra. 


\section{CAPÍtulo III: El MÁrtir Sublime}

\section{Análisis genealógico de El príncipe constante}

"Si ves a un hombre intrépido en los peligros, entre los apetitos intacto, entre las adversidades feliz, entre las tempestades apacible, que contempla a los hombres desde lugar superior y desde lugar igual a los dioses, ¿no sentirás el impulso de venerarle?” (Lucio Anneo Séneca. Siglo I. Cartas a Lucilio.)

Ya hemos definido las funciones semánticas básicas de las fuerzas que interactúan en el relato dramático. Al aplicar una variante particular del análisis semiológico actancial hemos hallado que el objetivo principal que orienta a toda la obra es la voluntad del infante Fernando para imponer la victoria de la fe católica a sus enemigos. A partir de esta premisa, podemos ahora profundizar en el estudio de la trayectoria del protagonista con el fin de precisar las condiciones fundamentales para una interpretación representacional.

En ese sentido, es interesante tomar en cuenta el personaje histórico al que la ficción dramática hace referencia. Al respecto, el cronista Rui de Pina da cuenta de un prisionero que solicita su liberación llegando a mostrar para ello las ventajas de entregar Ceuta, según solicita en 1438 al rey de Portugal en:

Um escrito d'apontamentos que o Infante D. Fernando, estando ainda em Arzila enviou a elle e a seu conselho, em que desejoso sair de cativo, apontava algunas causas e razôes porque nom era servico del Rei, nem bem de seus Reinos mantener-se Cepta pelos Christâos, assinando os danos e perdas e grandes despesas que Portugal pela suster recebia; e assim alegando outras muitas fundadas em uma natural piedade por as quais Cepta se devia dar por ele. (Rui de Pina, Chrónica: 567.)

Muy diferente, sin embargo, es el encomio épico que hace Luis de Camôes:

Viu ser cativo o santo irmâo Fernando (Que a tâo altas empresas aspirabva), Que, por salvar o povo miserando Cercado, ao Sarraceno se entregava. Só por amor da pátria está passando A vida, de señora, feita escrava, Por nâo se dar por ele a forte Ceita. Mais o público bem que o seu respeita. Codro, por que o inimigo nâo vencesse, Deixou antes vencer da morte a vida; Régulo, porque a pátria nâo perdesse, Quis mais a liberdade ver perdida.

Este, por que se Espanha nâo temesse, 
A cativeiro eterno se convida!

(Camôes, Os Lusíadas: 108).

A pesar del contraste entre ambos relatos, éstos coinciden en el valor de la constancia del cautivo en su padecimiento y en el hecho firme de que las cortes de Leiria de 1438 deciden negar el intercambio de Fernando por la plaza africana de Ceuta.

El 13 de septiembre de 1437, Enrique y Fernando, gran maestre de Avis, pusieron sitio a Tánger. Habiendo acudido en su socorro el rey de Fez, 'Abd al-Haqq 'Ab Allah III, ${ }^{30}$ Enrique tuvo que acceder a un armisticio por el que se entregaría Ceuta a los moros y se dejaba en rehenes a varios caballeros portugueses, entre ellos a don Fernando, el hermano del rey don Duarte. Las cortes de Leiria negaron la rendición de Ceuta, pero favorecieron la idea de recuperar al infante por la fuerza. Don Duarte murió víctima de la peste en 1438, dejando escrito en su testamento que se rescatara a don Fernando con la entrega de Ceuta. Las negociaciones no tuvieron éxito debido a las exigencias de los moros. Más tarde el rey de Fez pidió exorbitantes sumas de dinero por el canje del infante. Portugal no quiso pagar el subido rescate y Fernando murió en cautividad. En el último periodo del cautiverio, cuando la idea del rescate parecía improbable, sufrió hambre y crueles tratos, hasta que expiró el 5 de junio de 1443. Su cuerpo embalsamado fue expuesto a escarnio, colgado de las almenas de Fez. Alfonso V, sucesor al trono portugués, conquistó Tánger en 1471 y obtuvo por negociación los restos del infortunado príncipe. (Valbuena Briones: 114).

El ambiente social y cultural (la promoción de la imagen de la monarquía en medio del enfrentamiento con los moros, el fervor religioso y patriótico, etc.) facilita equiparar en el mismo nivel la historia y la literatura en una aventura legendaria, por lo que no es de extrañar la evolución heroica del relato. En el teatro, se atribuye a Lope de Vega un primer acercamiento al tema en la Comedia famosa de la fortuna adversa del Infante don Fernando de Portugal, pero es Pedro Calderón de la Barca quien:

Nos "informa" de que, con don Enrique, como intermediario de la corte portuguesa, llega al cautivo la noticia de que va a restituirse Ceuta y es él [Fernando] quien se indigna con la propuesta y asume con pasión su cautiverio (si no hubiese otro medio para liberarlo).

Solamente desde El príncipe constante esta postura de martirio indudablemente voluntario, cuando la posibilidad de la liberación existía (lo que, repito, no tiene nada de histórico), empieza a marcar las leyendas peninsulares sobre don Fernando. (Resina Rodrigues: 468 y 469.)

\footnotetext{
${ }^{30}$ Calderón omite darle un nombre al Rey Moro de su Príncipe constante. En el estudio arqueofilológico implícito en el capítulo VI nosotros proponemos llamarlo "Abdalá", como una referencia directa al histórico 'Abd al-Haqq 'Ab Allah III, quien hoy sabemos fue quien mantuvo prisionero al infante Fernando.
} 
La aportación de Calderón sólo confirma la decisión de los historiadores sobre cómo la historia debía quedar más convenientemente registrada, o sea: como la tragedia poética del sacrificio heroico de un guerrero cristiano por su Dios y por su patria.

Fernando, the "constant prince", the brother of the Portuguese King Duarte, was one of the heroes of the Reconquista, the centuries-long struggle between the Christians and the Moors on the Iberian Peninsula. He was taken prisoner during the siege of Tangiers in 1438 and died five years later in slavery. As early as 1470 he was canonized. (Gerstinger, en Durán y González: 106 y 107).

El referente, más cultural que histórico, es pertinente puesto que para el católico Calderón su relato dramático no es una mera recreación ficcional, sino una fidedigna reconstrucción histórica, un drama histórico:

In Calderon's days, the battles of the Reconquista still lived so immediately in the memory of the people that this play is to be seen as one of Calderon's very few historical dramas rather than as a romantic recreation. (Gerstinger, en Durán y González: 109).

Ello, sin omitir -para ese contexto cultural- dentro de lo "histórico" a lo sobrenatural (como la aparición del espíritu fantasmal de Fernando):

Nor does this contradict the simultaneous representation of the miraculous, that is, the vision of the dead prince leading his army to victory. For Calderon, the miraculous played an essential part in history. (Gerstinger, en Durán y González: 109).

De ahí que no extrañe (no resulta inverosímil), y aun mejor se potencie, el carácter de un protagonista altamente virtuoso, mezcla de invencible caballero medieval con santo mártir. ¡Qué paradoja tan poética (invencible mártir)! Sus inagotables virtudes hacen de él un héroe en todo el sentido del término.

The basic ethical foundations of Calderon's image of the world, that is, honor and religion, are in no other of his works so inseparable interwoven. (Gerstinger, en Durán y González: 109.) 
Pero a diferencia de una comedia convencional "aristotélica" 31 , Fernando no halla en su aventura un desenlace precisamente feliz. Muere y sólo después de muerto gana. Muere y con su muerte nadie se ríe. Estamos ante una comedia nueva ${ }^{32}$ con final trágico, esto es, de una tragedia bajo las directrices dramatúrgicas de la comedia lopista que, al mismo tiempo que atiende las necesidades de entretenimiento del vulgo ${ }^{33}$ (Brito [o Cutiño] ${ }^{34}$ sí hace reír), tampoco queda mal con las exigencias para el tratamiento temático del honor y del decoro $^{35}$ : Fernando es un modelo de integridad moral -de constancia- a seguir.

Ya que hablamos de la comedia nueva, no está de más consultar lo que el mismo Lope, conocedor crítico de Aristóteles, anotara como diferencias entre comedia y tragedia:

\begin{abstract}
Ya tiene la comedia verdadera su fin propuesto, como todo género de poema o poesis, y éste ha sido imitar las acciones de los hombres y pintar de aquel siglo las costumbres. También cualquiera imitación poética se hace de tres cosas, que son plática, verso dulce, armonía, o sea la música, que en esto fue común con la tragedia, sólo diferenciándola en que trata las acciones humildes y plebeyas, y la tragedia, las reales y altas.

(Lope de Vega, Arte nuevo: vv. 49-60.)
\end{abstract}

\footnotetext{
${ }^{31}$ Aunque la existencia de un supuesto tratado monotemático del filósofo griego sigue en duda (su posibilidad la plantea ficcionalmente Umberto Eco en El nombre de la rosa), la tradición sugiere que una comedia verosímil debe premiar la virtud con una resolución alegre y castigar al vicio mediante el ridículo (de cualquier forma esta norma general ha sido históricamente bastante flexible).

32 "Comedia nueva" se tendió a llamar a toda la dramaturgia (comedias, tragedias, melodramas, tragicomedias, etc.) producida luego de la aparición del Arte nuevo de Lope de Vega. En el mismo sentido, se comenzó a llamar "comediante" a los actores de todo género, calidad y condición.

33 "Y escribo por el arte que inventaron / los que el vulgar aplauso pretendieron, / porque, como las paga el vulgo, es justo / hablarle en necio para darle gusto." (Lope de Vega, Arte nuevo: vv. 45-48.)

${ }^{34}$ El nombre varía dependiendo de si la edición corresponde al manuscrito de 1629 o a la princeps de 1636. Es Cutiño en 1629 y Brito en 1636. Importante es aclarar que para ese 1636 aparece un Juan Coutiño como noble soldado. Para evitar mayores confusiones, en esta tesis nos referiremos al gracioso simplemente como Brito.

35 "Los casos de la honra son mejores, / porque mueven con fuerza a toda gente; / con ellos las acciones virtüosas, / que la virtud es dondequiera amada, / pues [que] vemos, si acaso un recitante / hace un traidor, es tan odioso a todos / que lo que va a comprar no se lo venden, / y huye el vulgo de él cuando le encuentra; / y si es leal, le prestan y convidan, / y hasta los principales le honran y aman, / le buscan, le regalan y le aclaman." (Lope de Vega, Arte nuevo: vv. 327-337.)
} 
Aunque en efecto, nuestra obra imita las acciones de algunos hombres (aunque no cualesquiera) y nos pinta de los siglos XV al XVII las costumbres (la guerra, el patriotismo y el fervor religioso), recordemos, por cierto, que, exceptuando las intervenciones de Brito (argumentalmente más bien incidentales), El príncipe constante no habla sobre acciones humildes ni plebeyas, sino sobre las reales y altas del protagonista Fernando y sus contrincantes.

No es la única distinción que hace Lope de Vega entre los dos géneros dramáticos más importantes:

Por argumento la tragedia tiene

la historia, y la comedia, el fingimiento;

(Lope de Vega, Arte nuevo: vv. 111 y 112.)

Con respecto a su base argumental, observemos que en El príncipe constante los personajes, en general, no son mentirosos (sólo Brito se conduce de manera diferenciada, fingiendo ser valiente cuando en realidad es un mercenario miedoso ${ }^{36}$ ). El único equívoco o error significativo es el malentendido amoroso entre Muley y Fénix, pero no lo es tanto como para calificar la obra como comedia de enredos. El malentendido no es gracioso, sino doloroso, y no se produce por el fingimiento de sus agentes, sino por la pugna entre sus pasiones (los celos de Muley) y las convenciones sociales (la obediencia de Fénix a su padre $^{37}$ para casarse con Tarudante).

Por otra parte, el argumento de la obra atiende a todas luces un tema histórico, de donde -en suma- resulta plausible suponer que Lope de Vega, a partir de su propia teoría (el marco estético-conceptual de la comedia nueva), hubiera calificado la obra de su colega como una tragedia (inscrita, debemos reiterar, en el contexto estético de la comedia nueva).

No desconocemos que, de cualquier forma, Calderón sigue la nueva preceptiva a pie juntillas en su inserción del gracioso (Brito), aunque es de considerar que sus razones sean primordialmente pragmáticas $^{38}$ :

\footnotetext{
${ }^{36}$ Tópico común del personaje gracioso en la comedia nueva.

${ }^{37} \mathrm{O}$ su hermano, dependiendo de la edición (la filiación de Fénix cambia entre 1629, donde es hermana del rey de Fez, y 1636, donde ya aparece como su hija.)

${ }^{38}$ No omitimos reconocer que el personaje gracioso funcionaba como un importante contrapunto emocional, como un referente de la diversidad social de la época y, en el caso de Calderón, también como una dura sátira
} 
Lo trágico y lo cómico mezclado,

y Terencio con Séneca, aunque sea

como otro Minotauro de Pasife, harán grave una parte, otra ridícula, que aquesta variedad deleita mucho: buen ejemplo nos da naturaleza, que por tal variedad tiene belleza. (Lope de Vega, Arte nuevo: vv. 174-180.)

Vale mencionar por cierto que al objetivo pragmático de deleitar con la variedad tonal entre efectos trágicos y cómicos habría que sumar la intención, muy personal del autor y demasiado contextual como para ser claro para todo el público contemporáneo, de denunciar y ridiculizar a un cura farsante, depositando para ello la sátira en el personaje de Brito. Evangelina Rodríguez Cuadros pone los hechos en boca de Calderón en una entrevista ficcional:

Yo ya era miembro de la farándula, compadre de los recitantes y farsantas. Una noche, en el Mentidero de los representantes, unas copas de más hicieron que el actor Pedro Villegas se enzarzara a discutir con mi hermano Francisco, a quien habíamos admitido en casa, pese a los reproches de mi padre. Nos encalabrinamos, llamé a la Guardia y el Villegas se puso a correr como alma que lleva el diablo. Todos tras él, dio en refugiarse en el convento de las Trinitarias que allí mismo estaba. Yo iba el primero y no me atuve a nada. Cosas de juventud violar aquella clausura. Pasamos Justicia, amigos y muchedumbre abriendo de par en par las celdas. No hubo rastro del Villegas que se pasaportó a Osuna; pero el escándalo fue mayúsculo. Lope me escribió una dolidísima carta porque entre las monjas vejadas se hallaba su hija Marcela. Tenía razón el maestro por lo que le tocaba. Mas no aquel presuntuoso, fatuo, insaciable hablador sermonario y lúbrico mujeriego que fue Hortensio Paravicino que se permitió desenterrar el suceso ante el Rey en una misa de difuntos. Me vengué en lo que más le dolía. Hice que parodiara el gracioso Brito sobre las tablas uno de sus energuménicos sermones de Berbería con sus emponomios horténsicos, dignos de bufón vinoso. Quiso aún el fraile meneallo todo para que el Rey me castigara, pero sólo padecí días de arresto menor en casa. Aquel año de 1629 se estrenan dos de mis obras favoritas. La una, por el éxito portentoso en los corrales, La dama duende. La otra porque quise dibujar por vez primera, de manera íntegra, la dignidad humana y el valor de la tolerancia, $E l$ príncipe constante. $\mathrm{Y}$ en ella, precisamente, metí la morcilla de los versos contra Paravicino. Con lo que el cretino me debe su fama postrera. (Rodríguez Cuadros. Un discreto a voces: Entrevista (imaginada) con Don Pedro Calderón de la Barca).

contra personajes de la vida real (como veremos enseguida, el personaje ficticio Cutiño, luego Brito, representa a la persona real del sacerdote Hortensio Paravicino, adversario de nuestro autor). 
Como vemos, hoy muy pocos -casi exclusivamente eruditos- podrían restablecer la relación entre la caricatura que es Brito (diseñado como lo fue para esa tarea tan concreta) y su modelo original.

Volviendo a la trayectoria de nuestro protagonista, el caso es que Fernando, un héroe de estamento noble y virtuoso, muere; de donde se observa que su trayectoria como protagonista va de una buena situación (buena familia, buena posición social y económica, perfil honorable) a una mala (hecho prisionero, humillado, confundido con un cautivo cualquiera... y muerto).

En el caso de El príncipe constante, don Fernando de Portugal, podemos seguir una lenta y emocionante caída desde la cúspide del poder hasta el padecimiento de una muerte miserable. El protagonista aparece en escena como el soldado vencedor y generoso que perdona la vida y deja en libertad a su contrincante [Muley]. Al final del acto primero la fortuna ha mostrado ya su rostro desapacible, y don Fernando ha de rendirse al rey de Fez, a quien entrega su espada. En la corte musulmana permanece como huésped de honor, aunque sin libertad. Cuando el príncipe niega su canje por la entrega de Ceuta, pues sería perderla a los enemigos de la religión cristiana, pasa a ser un esclavo que tiene que sufrir humillaciones y vejámenes. En el acto tercero, los trabajos en los baños lo han convertido en un tullido que no puede alimentarse por su propia mano. Vive en un muladar y sufre hambre y enfermedades hasta que su cuerpo emana un hedor nauseabundo. En un país extraño, solo ante su destino, muere sin haber transigido en su misión. La ironía de la obra se presenta al llegar los ejércitos que vienen a socorrerle, cuando ha fenecido ya. (Valbuena Briones: 112.)

Esta trayectoria, sumada al tono solemne, heroico, poético en general en toda la obra, coincide con la definición más ortodoxa que se busque de cualquier tragedia:

Toda concepción realista del teatro trágico debe tener como punto de partida el hecho de la catástrofe. (George Steiner, La muerte de la tragedia: 12 y 13).

Al referirse a las tragedias clásicas de Sófocles, Shakespeare y Racine, el estudioso británico pareciera también estar definiendo crudamente, sin matices, el argumento de Calderón que estamos analizando:

Enredados por falsa retórica y movidos por impulsos políticos que no pueden explicar a conciencia, los hombres salen a destruirse entre sí, con una especie de furia sin odio. (Steiner: 11). 
Vista desde la más amplia perspectiva, con un distanciamiento despojado de historicismos y moralismos rígidos, ¿no es relativamente falsa retórica la poesía (inconcreta, abstracta) con la que Fernando se afana en justificar su fe (subjetiva, objetivamente ciega, materialmente inaprehensible, científicamente incomprensible)? Después de todo, además del honor y la dignidad de un héroe de la cristiandad (axiomas estrictamente morales), ¿qué otra cosa gana él con su pasión católica? Y ¿no son acaso auténticos impulsos políticos, casi inexplicables de otra manera, las razones "religiosas" que llevan al gobierno de Portugal más allá de sus fronteras para pelear en Marruecos? (La verdadera Tierra Santa queda más al este, por lo cual ese desplazamiento forzado de los moros tiene que verse, al menos en su forma más simple, como un aseguramiento de los reductos coloniales del imperio lusitano entrelazado con genuinas aspiraciones de evangelización.) Fernando, muy lejos de la prudencia de Galileo ${ }^{39}$, en vez de explicar a conciencia su proceder, termina de ajustarse a este perfil trágico al mostrarse como un combatiente enérgico, es decir con furia (desde que pisa el suelo africano como al cuello de su presa), pero sin odio personal contra sus rivales (lo que es ampliamente notorio en su trato con Muley y en su interés muy específico por la ciudad de Ceuta).

Yo he de ser el primero, África bella, que he de pisar tu margen arenosa, porque oprimida al peso de mi huella, sientas en tu cerviz la poderosa fuerza que ha de rendirte.

(Calderón. El príncipe constante.)

Otro estudioso, Alexander Parker, es uno de los que más se ha esforzado por defender la existencia de un modelo trágico en las obras de Calderón y asegura que en ellas: "sí es posible observar una concepción original, importante y válida de la tragedia, concepción que hasta ahora hemos pasado por alto y no hemos sabido ver" ("Hacia una definición de la tragedia calderoniana": 362). Sin embargo, sus ejemplos (La devoción de la cruz, Las tres

\footnotetext{
${ }^{39}$ Galileo prefirió abdicar el 21 de junio de 1633 formalmente de sus premisas copernicanas heliocentristas (o sea que prefirió no ser un mártir por la ciencia) y resguardar así la oportunidad de seguir defendiendo vivo que la Tierra Eppur, si muove! (muy prudente y de ningún modo necio). La posición de Fernando, en contraste, en su momento lo vuelve un héroe moral, impasible en su dogma cristiano (un mártir por la fe), pero a ojos contemporáneos imprudente y casi soberbio. Hoy sabemos que a partir del Renacimiento se demostró la necesidad de una reforma espiritual eclesiástica y de un reconocimiento de las pruebas empíricas de la ciencia y de los valores dialécticos de la filosofía grecolatina clásica, mientras que las consecuencias para el contrarreformismo, el dogmatismo, el fundamentalismo y el absolutismo fueron catastróficas (Portugal, España, Francia e Inglaterra perdieron sus imperios globales y muchos hallazgos tecno-científicos ralentizaron su desarrollo).
} 
justicias en una y El pintor de su deshonra) no incluyen a El príncipe constante (en parte porque considera que ahí la discusión ya ha fallado a favor del criterio "tragedia") ${ }^{40}$ y, por lo tanto, sus conclusiones siguen otra dirección:

En mi opinión, la visión dramática de Calderón con respecto a la naturaleza de la maldad moral es trágica y no casuística: todos los hombres, o mejor dicho cada hombre cava la tumba de otros hombres, y también la suya propia, pues ya que cada acto humano engendra otros actos en una irrompible cadena de causa y efecto, una acción medianamente malvada cometida por una persona puede combinarse con otra parecida cometida por otros y engendrar un desastre moral de primer orden. El mundo dramático de Calderón nos muestra que la responsabilidad individual choca frontalmente contra la fatalidad del nexo causal de la cadena de acontecimientos. (Parker: 375).

Como podemos ver, la explicación no puede ni siquiera aproximarse por comparación al argumento que nos ocupa. El príncipe constante no es una obra sobre la maldad moral, ni sobre los actos malignos de un protagonista que desencadenen a la larga malos efectos. Nuestro personaje estudiado sigue otra trayectoria:

Don Fernando, antes que nada, será el mártir cristiano que, como Cristo, sufre con "constancia", resignación y "paciencia" todos los tormentos, llegando al punto de casi desearlos para mostrar su fidelidad al Creador. (Resina Rodrigues: 476).

Por lo tanto, la teoría de Parker sobre algunas tragedias calderonianas no es aplicable en nuestra investigación. No queremos hacer aquí una definición genérica definitiva de la obra de Calderón por tratarse de una discusión teórica que rebasa nuestros propósitos, pero sí una provisional y consistente en la forma de una perspectiva lectora específica para los fines prácticos de representación escénica. Para ello, sí vale la pena rescatar la glosa que ha encontrado en El príncipe constante un paradigma trágico.

En Fernando se cruzan, evolucionan y gradúan con mucha sabiduría el patriotismo del guerrero, la fe desmesurada del cristiano y la aceptación de un martirio voluntario, aprovechando sugerencias de distintas versiones anteriores, pero organizando un coherente perfil de héroe de tragedia de la libertad. (Resina Rodrigues: 474).

Los elogios dedicados a El príncipe constante, leída como tragedia, no han sido pocos:

\footnotetext{
${ }^{40}$ Parker nunca pone a discusión la genealogía de El príncipe constante como tragedia.
} 
Goethe, who read this work aloud in the house of Johanna Schopenhauer, is said to have suddenly interrupted his reading because he was overcome with emotion. "If poetry were to be lost from the world," he said, "one could resurrect it once again through this play alone." And Joseph von Eichendorff called it "one of the most glorious tragedies ever written." (Gerstinger, en Durán y González: 106.)

Valbuena Briones traza con precisión el carácter trágico de Fernando como arquetipo del mártir cristiano:

El sufrimiento y los tormentos que padece, su situación precaria, conmueven y atemorizan y producen una catarsis. La misión que desea cumplir la lleva a un combate desigual en el que defiende el dictado espiritual, cuando sus medios son materiales -auténtico dilema trágico de la contingencia humana-. Este personaje iluminado que proclama la palabra de Dios se ve acometido por los engaños y asechanzas de los sentidos y por los esfuerzos de aquellos que luchan contra su causa. Concibe, por tanto, su existencia como un camino áspero, lleno de amarguras, y el mundo como un valle de lágrimas. La defensa de la virtud produce la "admiratio" del espectador y purga a éste de sus malos instintos. Corneille elaboró esta idea en su famoso Polyeucte, 1643. Calderón se había adelantado con El príncipe constante. (Valbuena Briones: 111.)

En este modelo trágico particular:

Man himself does not construct his fate, as in the drama of character; rather, he receives fate as a gift, even though this fate may bring him sorrow. His greatness lies in the fact that he nevertheless receives his fate with gratitude. His free will has made proper use of grace. Because of this, the dead prince is still able to bring victory to his people. (Gerstinger, en Durán y González: 108.)

Aquí se puede contra-argumentar que el desenlace, después de todo, es "feliz", dada la victoria final de los portugueses sobre los moros, la devolución honorable de Fernando a los suyos y el desposorio entre Fénix y Muley. Se trata de una apoteosis con efecto de justicia poética (entendida como modificación de la justicia debida a motivos artísticos), de innegable valor estético y espectacular. Empero:

Aunque accediéramos en la creencia de que la apoteosis final resta sentido trágico entendido esto como una abstracción filosófica-, la obra se encuentra en una tradición dramática que no obsta a la caracterización del género. Sófocles presenta la partida de Oedipus del monte Remeter con el reconocimiento apoteósico final de héroe, en Oedipus en Colonus. Eurípides en el Hippolytus hace que la diosa Artemis -dea ex machina- aparezca y confirme la nobleza del desdichado mancebo; y en Iphigenia en Aulis, Iphigenia es arrebatada por los dioses en el momento del sacrificio, para ser llevada a la morada celestial de los inmortales. Séneca, en Hércules en el Eta, termina la obra con la ascensión del héroe a los lugares olímpicos. En todos estos casos, el poeta trágico ha preferido la apoteosis del 
héroe a su ruina definitiva. Se trata, por tanto, de un tipo de tragedia que hay que tener en consideración. La apoteosis, por otra parte, significa un coup de théâtre de seguro y válido efecto dramático. (Valbuena Briones: 113.)

No es improbable, por lo tanto, una lectura donde quepa la resurrección, material o simbólica, del héroe dramático, su victoria poética:

El hombre es ennoblecido por el rencor vengativo o la injusticia de los dioses. No le vuelve inocente, pero le purifica como si hubiera pasado por las llamas. Por esto hay en los momentos finales de las grandes tragedias, sean griegas, shakespeareanas o neo-clásicas [incluyamos ya las barrocas], una fusión de pesar y júbilo, de lamentación por la caída del hombre y de regocijo en la resurrección de su espíritu. (Steiner, La muerte de la tragedia: 14.)

De todas maneras es claro que aun antes de la última aparición fantasmal de Fernando, éste ya ha cobrado vida eterna en el corazón conmovido de los espectadores. Argumentalmente su apoteosis es un plus que nos regala Calderón para no salir del teatro con el alma destrozada. Cabe sin embargo no ahondar más para este estudio representacional en torno a ese y otros aspectos: el análisis del final apoteósico, una indagación sobre el gracioso Brito y el profundizar en la anécdota secundaria de los amores entre Fénix y Muley. Ello con el propósito ya establecido de concentrarnos en la evolución actoral del protagonista literario hacia su resolución espectacular.

Este enfoque de lectura es análogo a los resultados alcanzados por otros estudios filológicos a obras de Calderón, como en el caso de la Tesis que Néstor López Reyes, apoyado en Aristóteles, Ruiz Ramón, etc., desarrolla sobre La cisma de Inglaterra.

Ayudado por la herramienta semiótica de los modelos actanciales que recomienda Ubersfeld se siguió de cerca la pista que deja el personaje o héroe trágico calderoniano a lo largo de su trayectoria dramática en La cisma de Inglaterra. Se demostró que la pieza cumple con los requerimientos y esquemas estructurales necesarios para tipificarla como una tragedia, aunque no al estilo de los autores clásicos, sino una tragedia cristiana moderna, como la consideran Ruiz Ramón, Álvarez Sellers o Alexander Parker. (Néstor López: 213.)

En efecto, como consecuencia de nuestro propio análisis (nuestra perspectiva lectora actoral) podemos determinar que El príncipe constante es una tragedia cristiana moderna. De hecho, el protagonista, Fernando, encaja por mucho en el perfil del héroe trágico. 
Según Aristóteles, las tragedias incumben a personajes de alta alcurnia y no bajos o plebeyos: "Y tal es precisamente la diferencia que separa la tragedia de la comedia, puesto que ésta se propone reproducir por imitación a hombres peores que los normales, y aquella a mejores." Uno más es el denominado fatuum, identificado como anuncio fatídico. (Néstor López: 213.)

Aquí recordemos los signos oscuros que ve Fernando antes de desembarcar en Tánger.

El alma traigo de temores llena, echada juzgo contra mí la suerte desde que de Lisboa, al salir, sólo imágenes he visto de la muerte.

[.....]

Si miro al mar, mil sombras considero;

si al cielo miro, sangre me parece

su velo azul; si al aire lisonjero, aves nocturnas son las que me ofrece;

si a la tierra, sepulcros representa

donde mísero yo caiga y tropiece.

(El príncipe constante, Jornada I.)

Como podemos constatar, se trata de la representación en símbolos de la fatalidad. La tragedia calderoniana, sin embargo, se distinguirá no por el arrastre potente de las fuerzas del destino hacia lo inevitable, sino por cómo la voluntad del protagonista decide por sí misma ajustarse a ese plan superior.

A partir de aquí el personaje realizará el ejercicio de su libre albedrío, pues no está marcado por la fatalidad desde su origen, como ocurre con los protagonistas de la tragedia clásica, para ir al encuentro del vaticinio anunciado, en donde el personaje se desenvuelve libremente en busca de su final funesto y siguiendo el franco ejercicio de su libertad que lo lleva paulatinamente hacia el cumplimiento irónico del anuncio. De esta manera se consigue el elemento del ethos en la mala interpretación por medio de un estado de ánimo en el carácter del personaje y a través del cual interpreta su vaticinio, elucidación que le es conveniente al fatuum. (Néstor López: 214.)

En el caso de El príncipe constante es importante hacer notar que nuestro protagonista Fernando yerra solamente en interpretar como venturosos los signos del destino, mas no así en cuanto al rumbo moral de sus actos, los cuales seguirán siendo los de un guerrero santo sin caer en debilidades ni tentaciones.

Sorbernos una nave una tormenta es decirnos que sobra aquella gente 
para ganar la empresa a que venimos;

vestir púrpura el cielo transparente

es gala, no es horror, y si fingimos

monstruos al agua y pájaros al viento,

nosotros hasta aquí no los trajimos;

pues si ellos aquí están, ¿no es argumento

que a la tierra que habitan inhumanos

pronostican el fin fiero y sangriento?

Esos agüeros viles, miedos vanos, para los moros vienen, que los crean, no para que los duden los cristianos.

Nosotros - pues - lo somos; no se emplean

nuestras armas aquí por vanagloria

de que en los libros inmortales lean

ojos humanos esta gran victoria.

La fe de Dios a engrandecer venimos.

Suyo será el honor, suya la gloria.

A servirle venimos, no a ofenderle:

Cristiano soy; haré como cristiano.

(El príncipe constante, Jornada I.)

Efectivamente, en su proceder Fernando será absolutamente consecuente con estas palabras empeñadas al filo de la batalla. Siempre será valiente, caritativo, casto y humilde. Todo lo contrario que Enrique VIII, el rey protagonista de la cisma de Inglaterra.

El libre albedrío y los actos responsables ejercidos y elegidos bajo la voluntad guían las acciones de Enrique, no obstante, éstas no están exentas de lances pasionales. El enamoramiento mueve las disposiciones de su carácter y lo hace seguir un objeto que no es el piadoso, como sí lo es al inicio de la obra, esto como un uso erróneo de la razón y el juicio (dánoia). Al contrario, lo mueve un gusto amoroso enfermizo y lujurioso por la joven dama Ana, -a los otros personajes los mueve un objeto diferente pero igual de obsesivo en su carácter pasional, premisas de su personalidad son la soberbia y la ambición respectivamente-. Con esto se cumple un dispositivo más en su afinidad con el personaje trágico: la hybris, entendida como exceso de obnubilación del raciocinio al dejarse llevar por pasiones egoístas que lo conducen a efectuar actos cuyas consecuencias son desastrosas. Esto genera un error de juicio al no usar debidamente la razón, que los conduce al cumplimiento del elemento de la hamartía, concebida como un error de juicio en la forma de actuar, error que desencadena la catástrofe. Posee relación con la ironía trágica en que el héroe se dirige a su perdición al engañarse, conscientemente en el caso de este tipo de tragedia cristiana, acerca de su vaticinio. (Néstor López: 214.)

Queda la posibilidad de juzgar como conducta irracional en Fernando el sacrificar su propia libertad, y a la larga su misma vida, sin dudarlo un segundo ante la posibilidad del rescate inmediato mediante la entrega del bastión de Ceuta. Sería locura, seguramente, si se tratara de un personaje común y corriente, mas recordemos que los héroes trágicos son entes 
superiores y que estamos, de hecho, ante un noble infante, gran maestre además de la Orden Católica de Avis, esto es: príncipe, soldado y sacerdote (los votos más genuinos de caballería eran los del sacerdocio: pobreza, castidad y obediencia).

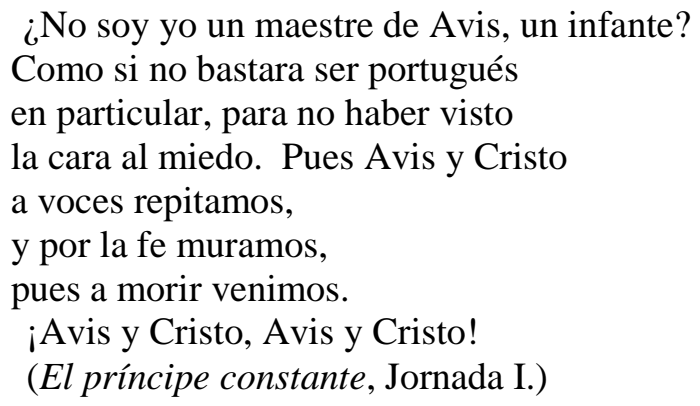

Fernando, pues, no se engaña. Sabe que viaja de la esclavitud al martirio y de ahí hacia su muerte segura. No podemos hablar de yerro trágico, pero acaso sí de peripecia, el cambio vital por el cual los personajes pasan de una buena fortuna a la adversidad, o viceversa.

La peripeteia es clave para comprender el avance de la construcción del héroe trágico. La misma lleva a otro elemento trágico, la anagnorisis o agnición como un reconocimiento del personaje al ver cumplido su fatum/destino, cambio desde la ignorancia al conocimiento. (Néstor López: 214.)

Fernando pasa de ser infante de las cortes lusitanas a ser cautivo. Como esclavo, no deja de ser constante en su fe. Ello es dramáticamente consecuente con los hipotextos hagiográficos de $O$ Infante Santo. En la obra de Calderón de la Barca, ya cerca de la muerte Fernando da una nueva exhibición de virtud en su propia anagnórisis.

¡Oh inmenso, oh dulce Señor, qué de gracias debo darte!

Cuando como yo se veía Job, el día maldecía; mas era por el pecado en que había sido engendrado; pero yo bendigo el día por la gracia que nos da Dios en él; pues claro está que cada hermoso arrebol y cada rayo del sol lengua de fuego será con que le alabe y bendiga. (El príncipe constante, Jornada III.) 
Cuidadosamente, el dramaturgo no lo hace un ser sobrenatural como para no padecer un profundo dolor físico y espiritual: el más puro sufrimiento humano.

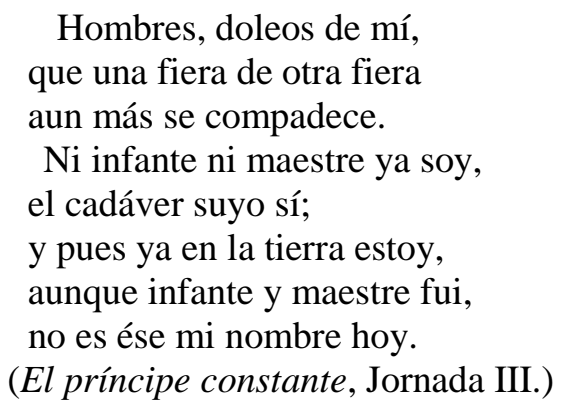

Se observa aquí que no hay ningún descubrimiento por parte del personaje respecto de su propia condición. La agnición de Fernando consiste en confirmar su fin inminente y en aceptarlo demandándolo incluso en un lance patético o pathos.

Finalmente se presenta el pathos o lance patético como una marca distintiva de toda tragedia en el momento de producirse la katastrophé final. Esta acción destructora o dolorosa, en donde el personaje expone abiertamente su condición desastrosa en medio de quejas terribles y patéticas, es un último elemento trágico que retoma Calderón para exhibir a sus personajes en actitud desesperada. (Néstor López: 215.)

Incluso aquí Fernando se distingue pues, aun en medio de su terrible agonía (hambre, sed, enfermedad, cadenas, desnudez y trabajos forzados en los baños y mazmorras), no es dominado por la desesperación.

Quien esto sabe, ¿qué busca?

Claro está que no será

la vida. No admite duda.

La muerte sí; ésta te pido

porque los cielos me cumplan

un deseo de morir

por la fe; que aunque presumas

que esto es desesperación

porque el vivir me disgusta, no es sino afecto de dar la vida en defensa justa de la fe, y sacrificar a Dios vida y alma juntas; y así, aunque pida la muerte, el efecto me disculpa.

(El príncipe constante, Jornada III.) 
Hay que insistir en recordar que no estamos ante un personaje común y corriente, que no estamos ante un simple mortal, sino ante un santo. Un santo es un ser humano invicto en la virtud, pero mortal al fin.

\author{
Pero, ¿qué mal no es mortal \\ si mortal el hombre es, \\ y en este confuso abismo \\ la enfermedad de sí mismo \\ le viene a matar después? \\ Hombre, mira que no estés \\ descuidado. La verdad \\ sigue: que hay eternidad \\ y otra enfermedad no esperes \\ que te avise, pues tú eres \\ tu mayor enfermedad. \\ (El príncipe constante, Jornada III.)
}

En la virtud infalible de Fernando no podemos olvidar la Antígona de Sófocles donde, consciente perfectamente de las consecuencias fatales que le traerán sus actos, la protagonista decide dar sagrada sepultura a su hermano, en contra de las órdenes del Estado, pero solidaria con una necesidad divina superior. Antígona, hija de Edipo, se autoinmola para recuperar el orden cósmico pervertido por la guerra entre sus hermanos. Los críticos como Ariel Rivera le llaman tragedia de sublimación.

Tragedia de sublimación. En la tragedia de sublimación se manejan, en un solo texto, todos los valores más acertadamente calificados como absolutos: la vida, el espíritu, la religión, la conciencia individual y el amor.

Protagonista de sublimación. En la defensa heroica de uno de esos valores, el protagonista está defendiendo al mismo tiempo todos los demás y, por ende, cobra la grandeza de: el superhéroe, el santo, el iluminado, el sumo sacerdote o el semidiós, y por ese extraordinario heroísmo, que equivale también a ponerse al nivel del absoluto, la sociedad lo considera un agresor.

(Virgilio Ariel Rivera. La composición dramática. México: Gaceta: 1993. 95.)

Algo similar ocurre con Fernando, pues es con su oblación personal que se abren las puertas para la victoria eventual de los portugueses y de la fe. La sociedad cristiana, pues, es a largo plazo favorecida por la postura ética de este héroe que lucha solo, pues falla en socorrerle su círculo inmediato: su hermano Enrique, el general moro Muley, la princesa Fénix. Éstos ven incongruente el proceder de Fernando, lo juzgan como defensor de sus 
intereses personales y le propician sucumbir. Ahora bien, este relato dramático en particular parece ser por su propia cuenta una excepción entre los moldes de sublimación.

La forma dramática más elevada, más puramente concebida es la tragedia de sublimación y nos parece extraño que la cristiandad sólo haya salvado tragedias de destrucción para la posteridad. [Desde Edipo Rey de Sófocles hasta Largo viaje de un día hacia la noche de Eugene O’Neill.] Nos inclinamos a creer que fueron salvadas únicamente por el gusto del teatro profano, en tanto que todos los modelos de sublimación fueron expresamente destruidos, y su forma reservada para el gran drama litúrgico, el sacrificio de la misa o la tragedia de Jesucristo. (Virgilio Ariel Rivera. La composición dramática. México: Gaceta, 1993. 96.)

La observación de Ariel Rivera es interesante porque reduce todas las posibilidades de supervivencia del subgénero de la tragedia de sublimación a la celebración religiosa católica: la misa $($ misa $=$ drama litúrgico $=$ eucaristía $=$ tragedia de Jesucristo). En efecto, el sacrificio en cuerpo y sangre de Fernando lo asemejan al ritual eucarístico (lo que rebasaría el criterio de "drama de santos"), sin llegar a serlo explícitamente, y otras acciones asemejan otros rituales católicos sacramentales: el escuchar a Muley y a Fénix en sus remordimientos se asemeja a la confesión-reconciliación, la prueba de la guerra es un bautizo (de fuego), la bendición de la unión de Fénix y Muley es una boda, enfrentar con valor la adversidad es confirmación, su ofertorio sagrado personal es el voto sacerdotal, su agnición es unción de los enfermos. En otras palabras, además de los protocolos básicos de la misa católica se cumple también con la presencia simbólica de todos los sacramentos, llenando así los requerimientos del auto sacramental, aunque de manera por demás sobreestilizada, rebuscada, en otras palabras: barroca. Estaríamos entonces ante un drama no sólo sublime, sino también espiritualmente edificante, profundamente vital.

¿De dónde vendría entonces la tragedia? ¿Quizá "de la alegría”, de la salud exuberante, del exceso de vitalidad? (Nietzsche. El origen de la tragedia. 14.)

Calderón mismo debió enfrentar en su momento el dilema de cómo tratar dramáticamente un personaje rayante en los límites de lo humano sin caer en el absurdo, sin faltar a la hagiografía, sin perder espectacularidad. De ahí que las decisiones creativas seguramente sorprendieron al mismo autor, pues éstas consistieron -ahora lo observamos- en crear un paradigma completamente original en el marco de la Tragedia Clásica, de la Comedia 
Nueva, de la tragedia cristiana moderna y de la tragedia de sublimación: el modelo trágico del mártir cristiano, inaugurado magistralmente con El príncipe constante. Sin embargo, incluso esta última afirmación nos parece limitante para abarcar todo los horizontes de lectura que la obra ofrece, más profundos de lo que aparenta la superficie. Acaso podemos contentarnos si recordamos que justamente muchas posibilidades hermenéuticas son lo que define a una gran obra de arte. Nuestras últimas consideraciones a este respecto serían las siguientes:

1. Los amores entre Fénix y Muley integran un relato dramático completo, digno de una tesis aparte y de su propio estudio representacional. Su trayectoria como personajes se aparta de la "lectura trágica" que proponemos sobre El príncipe constante pues, por definición, su emotiva lucha de valores entre su amor "bueno" y las adversidades y opositores "malos" sugieren un melodrama.

2. No seríamos los primeros en omitir a Brito -el gracioso- de un estudio representacional sobre este drama. Antes lo hicieron Goethe (en el siglo XIX) y Grotowski (en el siglo XX). Nuestra premisa, similar a la de ellos, parte de subrayar los valores trágicos que, entre muchos otros, ofrece la obra, para integrar una experiencia estética más concreta y eficaz para el espectador contemporáneo.

3. Valdría la pena proponer una concepción escénica donde la dimensión espiritual del protagonista fuera descubierta como el producto de una activación emocional, moral e intelectual del receptor-espectador inspirada por una interpretación actoral en vivo y no por la tramoya, es decir, como un efecto estético propiciado desde la oralidad y la gestualidad actor y no solamente por los efectos fantásticos del relato dramático (como el fantasma de Fernando volando por los aires).

4. Al igual que hiciera el mismo Calderón ${ }^{41}$, el primer motivo para una adaptación dramatúrgica tendría que obedecer a las condiciones objetivas de representación, que en nuestro caso consiste en la ausencia de vastos recursos materiales para sacar adelante una producción ostentosa de la puesta en escena. Poseemos, en cambio, dos recursos inmateriales fundamentales: una investigación teórica ex profeso y una preparación actoral profesional. No hay beca, fideicomiso, patrocinador ni mecenas.

\footnotetext{
${ }^{41}$ Con El mágico prodigioso y con La amistad coronada (Ver capítulo 1 de esta tesis).
} 
Otra condición representacional es el propósito fundamental de nuestra investigación de concentrarnos en los aspectos interpretativos actorales de un solo personaje: el protagonista Fernando. Descartar las aristas de lo general (elenco numeroso, escenografía imponente, vestuario de lujo, etc.) nos permitirá apretar exhaustivamente sobre el particular (una lectura actoral lo más fina posible).

5. Proponer un discurso escénico con estas acotaciones implicaría despojarlo de ornamentaciones y efectos ajenos a nuestro actual contexto cultural, lo cual puede facilitar la experiencia del receptor-espectador en cuanto a la comprensión clara de la intentio del autor y el goce estético de los valores literarios y espectaculares fundamentales de la obra.

Todo esto podremos analizarlo en el proceso de evolución de esta obra dramática en un texto espectacular (y luego en su representación), es decir, en el paso de la literatura como tal al de su definición como partitura de un espectáculo (y, eventualmente, como un discurso escénico). Por lo pronto y hasta aquí sólo hemos querido demostrar que, sin definir categóricamente a El príncipe constante como una tragedia convencional, la obra admite positivamente una lectura interpretativa de carácter trágico. En los siguientes dos capítulos intentaremos resolver un problema del más alto interés: cómo justificar una concepción escénica reduccionista como la aquí propuesta para la primera obra maestra de Calderón sin basarnos sólo en los criterios materiales de su producción, esto es, cómo fundamentar estéticamente nuestra interpretación espectacular. 


\section{CAPÍTUlo IV: ÉXTASIS E ILUMINACIÓN}

\section{Estética teatral del Barroco}

La denominación del arte del siglo XVII bajo el nombre de Barroco es moderna. El concepto fue aplicado en el siglo XVIII, cuando aparece por primera vez, todavía exclusivamente a aquellos fenómenos del arte que eran sentidos, conforme a la teoría del arte clasicista de entonces, como desmesurados, confusos y extravagantes. (Hauser, Historia social de la literatura y el arte I. 498. Énfasis mío. ${ }^{42}$

Considerando antes que nada la intención del dramaturgo, supongamos de una vez por todas que la mejor estrategia de lectura para un texto dramático es concebir su puesta en escena. Para desarrollar una concepción de puesta en escena de El príncipe constante es pertinente tomar como referencia la lógica visual (la iconología, más que una iconografía) del contexto cultural de producción: qué se leía (entendiendo la noción de texto como escritura e imagen) y cómo se imaginaba eso visualmente (construcción del imaginario colectivo), partiendo de que las evidencias sugieren que los dramaturgos del Siglo de Oro en ocasiones se inspiraban en la pintura coetánea para desarrollar escenografías y efectos que luego serían construidos por especialistas italianos (Lotti, Rizzi, Caudeli) con novedosos conocimientos de perspectiva y ostentosa ornamentación. El claroscuro, la iluminación, la arquitectura, la decoración, los temas religiosos y mitológicos son todos elementos que hablan de una estética donde predominó lo espectacular: el Barroco. Parece ser que esa lógica también inspiró modos de interpretación actoral.

Así pues, acerca de la estructuración de acotaciones escenográficas con fundamento pictórico, se nos señala que:

No se trata sólo de un tipo de acotación que se articula bajo la fórmula como las pintan o como la pintan (por ejemplo, en La fiera, el rayo y la piedra de Calderón: “Ábrese la gruta, y vese en lo más lejos de ella a las tres parcas, como las pintan...”), sino la directa relación de esta teoría con los mecanismos de maquillaje de los actores. (Rodríguez Cuadros. "Registros y modos de representación en el actor barroco", en Díez Borque. 43 y 44.)

En efecto, los tratados de pintura de la época funcionan también como manuales de caracterización teatral. Por ejemplo, acerca del maquillaje:

\footnotetext{
${ }^{42}$ Hauser hace referencia a Francesco Milizia, Dizionario delle belle arti del disegno de 1797.
} 
Los accidentes mudan y alteran aquel mismo color, según la pasión, y moción interior o movimiento exterior, encendiéndose, o perdiendo el color, ya blanquecino, y ya verdinegro, según la calidad de la causa, y del humor, inquietado por ella: cólera, flema, sangre o melancolía. (Vicente Carducho. Diálogos de la pintura. Su defensa, origen, esencia, definición, modos y diferencias. Madrid: Turner, 1979 [siglo XVII]. 160.)

Y quizá incluso como vademécums de actuación, pues al hablar de la representación gráfica de los personajes, se implican utilidades para el actor:

Se alteran las formas en mayor, o menor, y más o menos dilatadas, porque la admiración, espanto y afirmación, dilatan y abren, según la acelerada acción de aquel que la haze. Y el llanto, aflicción y temor, las regoce, retira y disminuye. Y los músculos, nervios y arterias, se fortalecen y atenazan, según la acción y edad. Y los ojos, boca, narizes, manos, ombros, y otras partes del cuerpo hazen lo mismo, conforme a la correspondencia que tuvieron las causas que las mueven: y todas estas alteraciones son de los propios interiores y exteriores, como está advertido. (Carducho. Diálogos de la pintura... 160.)

\section{Rodríguez Cuadros observa:}

Me quedan pocas dudas, dada la difusión cultural de estos acontecimientos en la época, de que los actores no advirtieran la utilidad de seguir las pautas que indica una teoría de la representación aneja como es la pintura para modelar tipos (en maquillaje, gesto y atavío) como los siguientes [citando a Carducho]: el justo, el prudente, el piadoso, el lujurioso, el desvergonzado y mentiroso, la avaricia, la crueldad, el temor, el llanto o el melancólico. [...] Cuando se cita [refiriéndose a Carducho] la tipología de la locura, la gestualidad es la correspondiente a la insana exacerbación del entremés; la fortaleza diseña al galán, como la majestad los movimientos graves y pausados... para los personajes trágicos [cita a Carducho]: "El semblante magnífico, las manos siempre ocupadas en cosas graves, altas y generosas: la planta firme y grave, y todo el cuerpo algo derecho, y no descompuesto, los ojos tardos, graves y despiertos." (Rodríguez Cuadros. "Registros y modos..." 44.)

Antes ya estudiamos las peculiaridades literarias de El príncipe constante. Así pues, apuntando a su escenificación, analicemos ahora cuánto más nos aporta la iconología barroca a la teatrología en general y a la actoralidad en particular.

Burckhardt y los puristas posteriores, como, por ejemplo, Croce, que son incapaces de liberarse del racionalismo frecuentemente estrecho del siglo XVIII, perciben en el Barroco sólo los signos de la falta de lógica y de tectónica, ven sólo columnas y pilastras que no sostienen nada, arquitrabes y muros que se doblan y retuercen como si fueran de cartón, 
figuras en los cuadros que están iluminadas de modo antinatural y que hacen gestos antinaturales como en la escena, esculturas que buscan efectos ilusionistas, cuales corresponden a la pintura, y que, como se subraya, deben quedar reservados a ésta. (Hauser. Historia social de la literatura y el arte I. 498 y 497.)

Como vemos, las relaciones de la lógica visual del siglo XVII con el fenómeno teatral son evidentes: apariencias, estructuras falsas, efectos especiales que buscan todos cautivar al espectador. En general, reiteramos que se lo que se define claramente es una iconología teatral donde las estéticas visuales y escénicas se retroalimentan.

\section{Origen}

La espectacular escenotecnia calderoniana (misma que enmarca el imaginario de $\mathrm{El}$ príncipe constante), como sabemos, sólo pudo materializarse con un conocimiento y un estilo importados de la cuna del Barroco: Italia.

Cuando se plantea iniciar el análisis de la época del Barroco, es evidente que la lógica lleva a iniciar el recorrido en Italia, y más concretamente en Roma. (Historia del arte. 1550.)

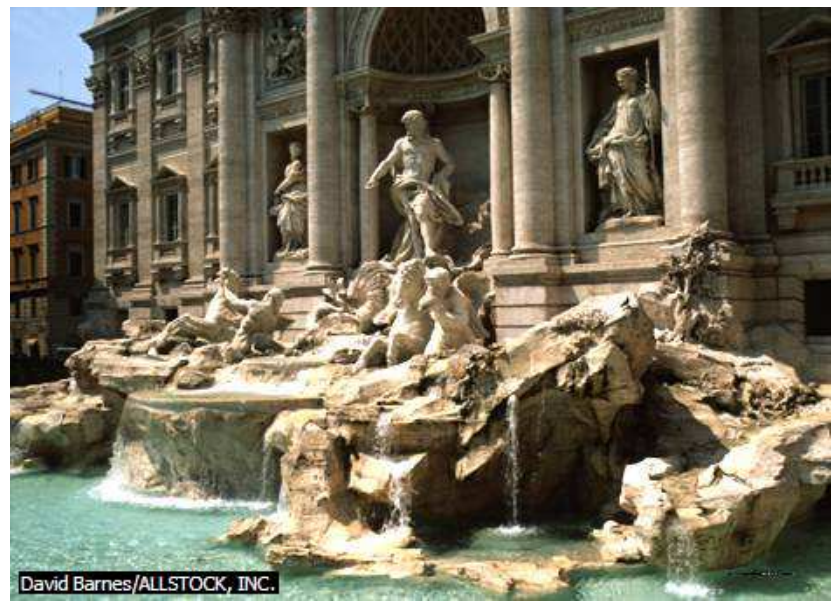

Designed by Nicola Salvi and completed in the 18th century, the Trevi Fountain in Rome, Italy, is an example of baroque art. Statues of gods and horses adorn the fountain, and the two Tritons on either side of Neptune, the Roman god of the sea, seem ready to conduct Neptune's winged chariot over the water. According to tradition, tossing a coin into the Trevi Fountain ensures a return visit to Rome.

(David Barnes/ALLSTOCK, INC.) ${ }^{43}$

Los descubrimientos (Colón, Galileo), los inventos (Gutemberg), la Reforma Protestante (Calvino, Lutero y Enrique VIII) y el Renacimiento (Da Vinci, Rafael, Miguel Ángel)

43 "Trevi Fountain, Rome." Encarta 2000. 
dieron otras perspectivas al mundo, pero también detonaron crisis. Las novedades invitaban a aprender de todo y a combinarlo.

El barroco en Italia, animado por el espíritu de la Contrarreforma, reaccionó contra los refinamientos estéticos del manierismo de formas diferentes. La vuelta al clasicismo, predicada por los Carracci, quienes fundaron en 1585 una academia de arte llamada de los Incamminati (Encaminados) donde se discutía sobre arte y se enseñaba perspectiva, arquitectura y anatomía, sostenía que el medio para alcanzar la belleza pasaba por la práctica de un eclecticismo que llevara a tomar lo mejor de cada maestro. (Historia del arte. 1549.)

Así, autores como Caravaggio se dejaron influir por Miguel Ángel:

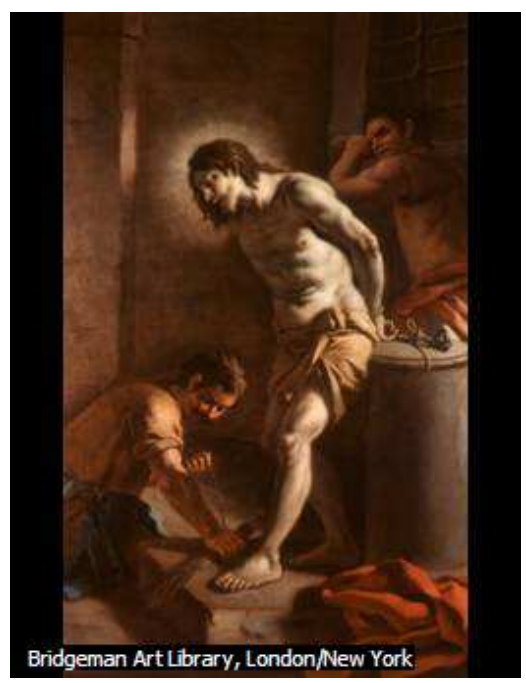

Flagellation of Christ, oil painting by the 17th-century Italian artist Caravaggio, depicts its subjects in a naturalistic style that was influenced by Michelangelo. Caravaggio's use of tenebrism, a heightened variation of chiaroscuro, gave his paintings a powerful sense of drama.

(Bridgeman Art Library, London/New York.) ${ }^{44}$

Naturalismo, tenebrismo y claroscuro son técnicas que se ven más que nunca acompañadas de un lenguaje escénico: drama, teatralidad, escenografía, espectacularidad. Igual que Caravaggio hiciera con Miguel Ángel, Artemisa Gentileschi tomó lo mejor de Caravaggio para ejecutar sus propias dramaturgias visuales.

44 "Flagellation of Christ." Encarta 2000. 


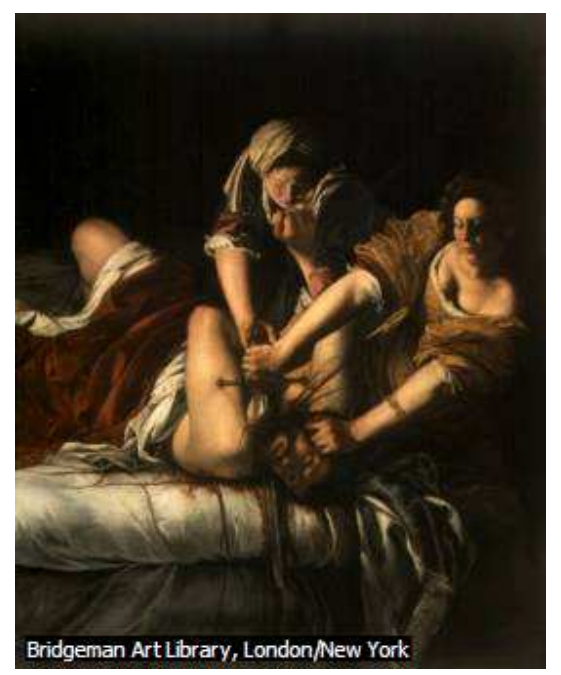

Judith Slaying Holofernes (about 1620) was painted by the Italian baroque artist Artemisia Gentileschi. The use of chiaroscuro (contrast of light and dark) in this piece creates a sense of drama, and the influence of Italian painter Caravaggio can be seen. Gentileschi, who was one of the first women to be recognized as a serious artist, often portrayed women as strong, decisive figures. The painting is 199 by $162.5 \mathrm{~cm}$ (78 by $64 \mathrm{in}$ ).

(Bridgeman Art Library, London/New York.) ${ }^{45}$

Los y las artistas acuden a escuelas, aprenden, viajan y, en efecto, heredan y mezclan su saber en estilos personales no exentos de una cualidad común a casi todos: lo teatral.

\section{Definiciones del Barroco}

Nunca un movimiento artístico y literario había sido tan definidamente teatral:

Frente al Renacimiento considerado un arte del ser, se identifica al barroco como un arte del parecer (Historia del arte. 1538.)

Como sabemos, la apariencia y el fingimiento son bases del arte del actor. El lenguaje común -y más el artístico- de la época se impregnan de muchos otros sentidos igualmente teatrales, como observa Rodríguez Cuadros con la palabra gesto:

El Diccionario de Autoridades [impreso entre 1726 y 1739] introduce una apreciación disciplinar claramente escénica, de técnica mimética del actor: "semejanza, apariencia y parecer a la vista." (Rodríguez Cuadros. Registros y modos... 41.)

O incluso con la palabra alma:

45 "Judith Slaying Holofernes." Encarta 2000. 
[La palabra alma...] se derrama en el Diccionario [de Autoridades] en una distribución forense de atributos a profesionales como el orador, el músico y sobre todo el "cómico que representa con afecto y gallardía, y acompaña con acciones propias lo que dize, y así de otros que animan con la expresión de lo accionado lo que la voz pronuncia.” (Rodríguez Cuadros. Registros y modos... 41.)

La siguiente pintura despliega varios actores (véase el gesto del Capitán Franz Banning Cocq orientando a la tropa hacia el espectador) en un espacio artificiosamente iluminado (nótese en especial la niña emergiendo entre los soldados y también al oficial a un costado del capitán) en un montaje inequívocamente teatral:

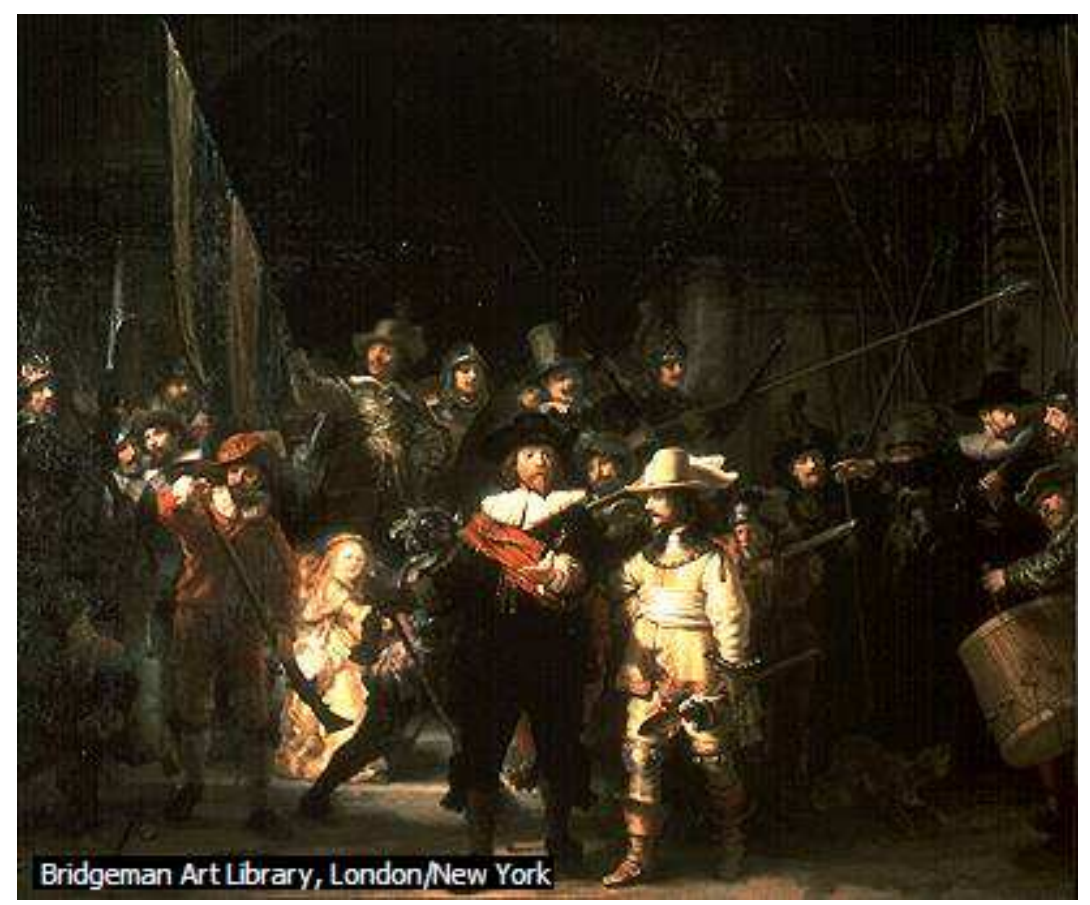

The Night Watch (1642) by the Dutch artist Rembrandt van Rijn was also known as The Shooting Company of Captain Frans Banning Cocq because it was a group portrait commissioned by a militia company. It shows the company emerging from its headquarters and heading for a ceremonial parade. Originally much larger, the painting was cropped in 1715 when it was moved to Amsterdam's town hall.

(Bridgeman Art Library, London/New York.) 46

Arnold Hauser evoca el Kunstgeschichtliche Grundbegriffe (1929) de Heinrich Wölfflin, para confirmarnos los elementos de lo que para él define una "intención cinematográfica" del arte visual Barroco (pintura, escultura, arquitectura), pero que nosotros apreciamos en sus valores teatrales (literatura dramática y escena):

46"The Night Watch." Encarta 2000. 
La lucha por lo "pictórico", esto es, la disolución de la forma plástica y lineal en algo movido, palpitante e inaprensible [como la representación teatral]; el borrarse los límites y contornos para dar la impresión de lo ilimitado, inconmensurable e infinito [como la escenografía moderna a la italiana, con su caja y sus perspectivas]; la transformación del ser personalmente rígido y objetivo en un devenir, una función, un intercambio entre sujeto y objeto [como la actuación entendida como una dialéctica entre persona y personaje]. [.....] Los sucesos representados parecen haber sido acechados y espiados [como el voyerismo intencional y activo del espectador teatral], todo signo que pudiera delatar interés por el espectador es borrado [como en el fenómeno teatral denominado cuarta pared], todo es representado como si fuera aparente voluntad del acaso [como ante una actuación naturalista que hace parecer que el drama visto es vida que se vive en ese momento]. (Hauser. Historia social de la literatura y el arte I. 500 y 501.)

\section{Contexto cultural}

Al hablar de un refinamiento -incluso rebuscamiento- estético, teórico e ideológico, necesariamente tenemos que hablar de civilización y modernidad.

Al barroco considerado como otoño del Renacimiento, por no decir de la Edad Media, se contrapone un barroco visto como amanecer de la civilización moderna (Historia del arte. 1539.)

El público del Barroco, defiende Hauser, tiene aspiraciones tanto intelectuales como espirituales:

Todo público que se hace más ilustrado, más entendido en arte, más pretencioso, desea este realce de excitantes. Pero junto al estímulo de lo nuevo, difícil y complicado se expresa aquí también, ante todo, el afán de despertar en el contemplador el sentimiento de inagotabilidad, incomprensibilidad, infinitud de la representación, tendencia que domina en todo el arte barroco. (Historia social de la literatura y el arte I. 502.)

Precisemos un poco más el avance que el Barroco significó:

El mundo barroco es extenso. Los descubrimientos geográficos ampliaron el mundo occidental más allá de las míticas "columnas de Hércules" [Gibraltar al norte y Ceuta al sur, siendo esta última la plaza disputada en El príncipe constante]; las investigaciones de Copérnico, Galileo y Kepler destruyeron la fe en la tierra y en el hombre como centros del universo para proponer otros horizontes infinitos, móviles y mutables. Giordano Bruno fue quizá el mayor propagador de la energía vital del infinito: "Infinito espacio posee infinita disposición, y en ella se nota infinito acto de existencia”. (Historia del arte. 1540.) 
En la siguiente pintura, es notorio cómo el paisaje meramente decorativo cede paso a un horizonte cargado de sentidos “infinitos, móviles y mutables”. El efecto remite nuevamente a lo teatral, puesto que en el escenario teatral todo cobra significado a los ojos del espectador.

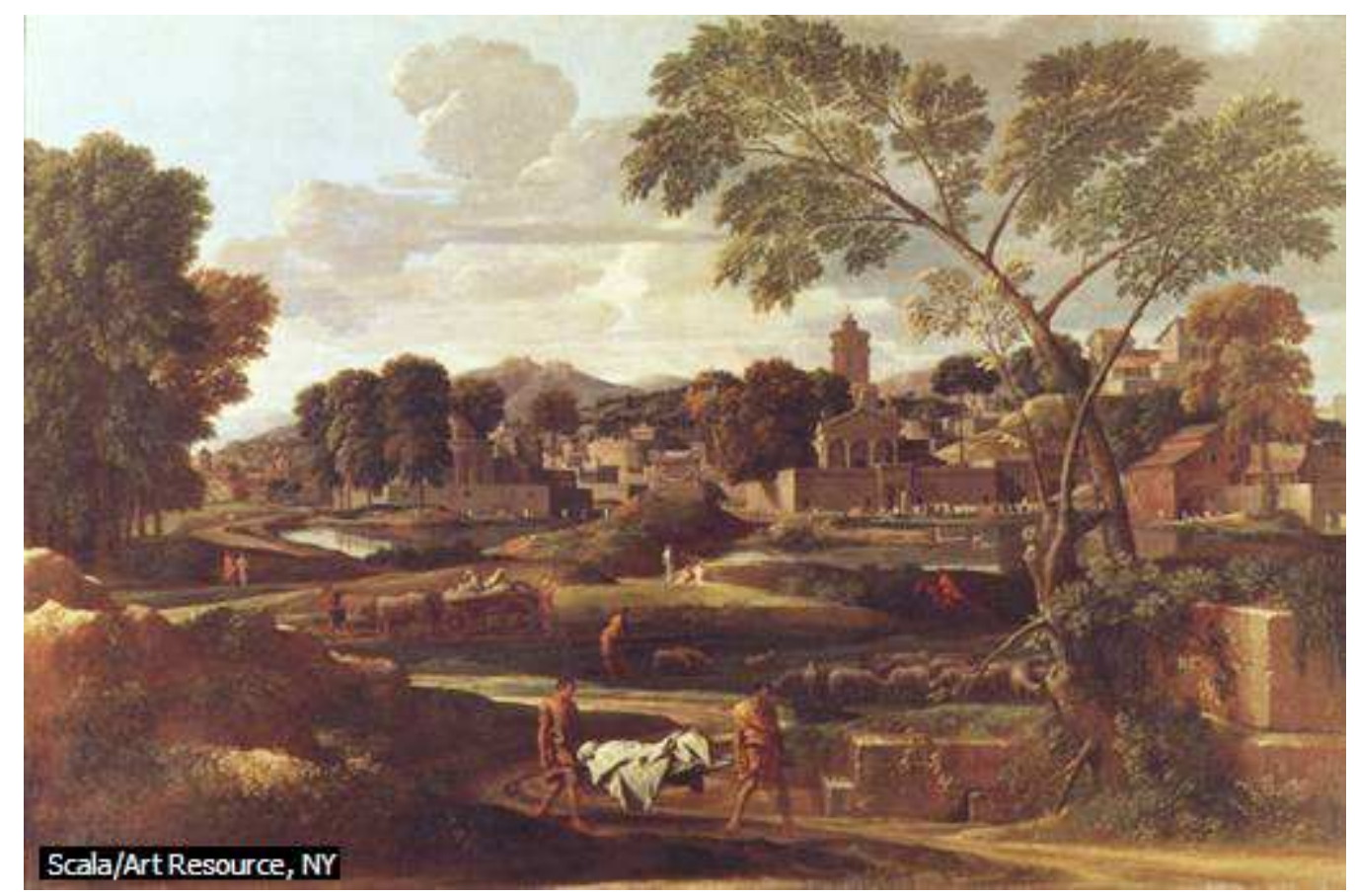

In Landscape with the Burial of Phocion (1648, Louvre, Paris), 17th-century French baroque artist Nicolas Poussin used mathematically derived spacing and austere colors to create an ordered, solemn painting. Often identified with the French school of art known as neoclassicism, Poussin utilized logical constructions and sober tones to emphasize his classical subjects. A careful consideration of his paintings often reveals a historical, literary, or biblical story. This work depicts the burial of Athenian general Phocion, who was put to death in $317 \mathrm{BC}$ on a false charge of treason.

(Scala/Art Resource, NY.) $)^{47}$

Al observar con cuidado, veremos que el hermoso paisaje tan lleno de vida trata en realidad acerca de un funeral legendario, es decir, es el escenario de un drama trágico. La ampliación del espacio en significados y posibilidades convocan, como en el teatro, la participación activa del espectador. Un ejemplo concreto es el salón, donde el espacio cotidiano de convivencia se transforma, por medio de la decoración barroca, en una escenografía donde el visitante se convierte en el actor, afectando incluso su comportamiento que, a su vez, se hace extravagante, extracotidiano.

47 "Landscape with the Burial of Phocion." Encarta 2000. 


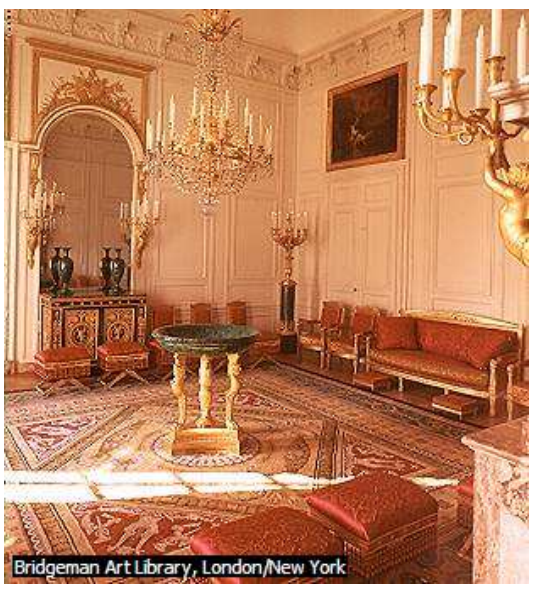

The reception room at the palace at Versailles, France, is designed in the baroque style. Some of the features include ormolu ornamentation above the mirror, classical motifs in the rug and candleholders, and intricate carved friezes (boiserie) along the top of the walls. The furniture style is far simpler than that of the rococo era that followed. (Bridgeman Art Library, London/New York.) ${ }^{48}$

Se nos explica:

Los salones de los espacios aristocráticos, las bóvedas y las cúpulas de las iglesias se abren hacia el más allá, a los cielos del mito y de la religión implicando profundamente al espectador. (Historia del arte. 1540.)

Igual pasa entonces con el templo religioso, que conmueve y solemniza para hacer de la contemplación estética una experiencia religiosa, mística.

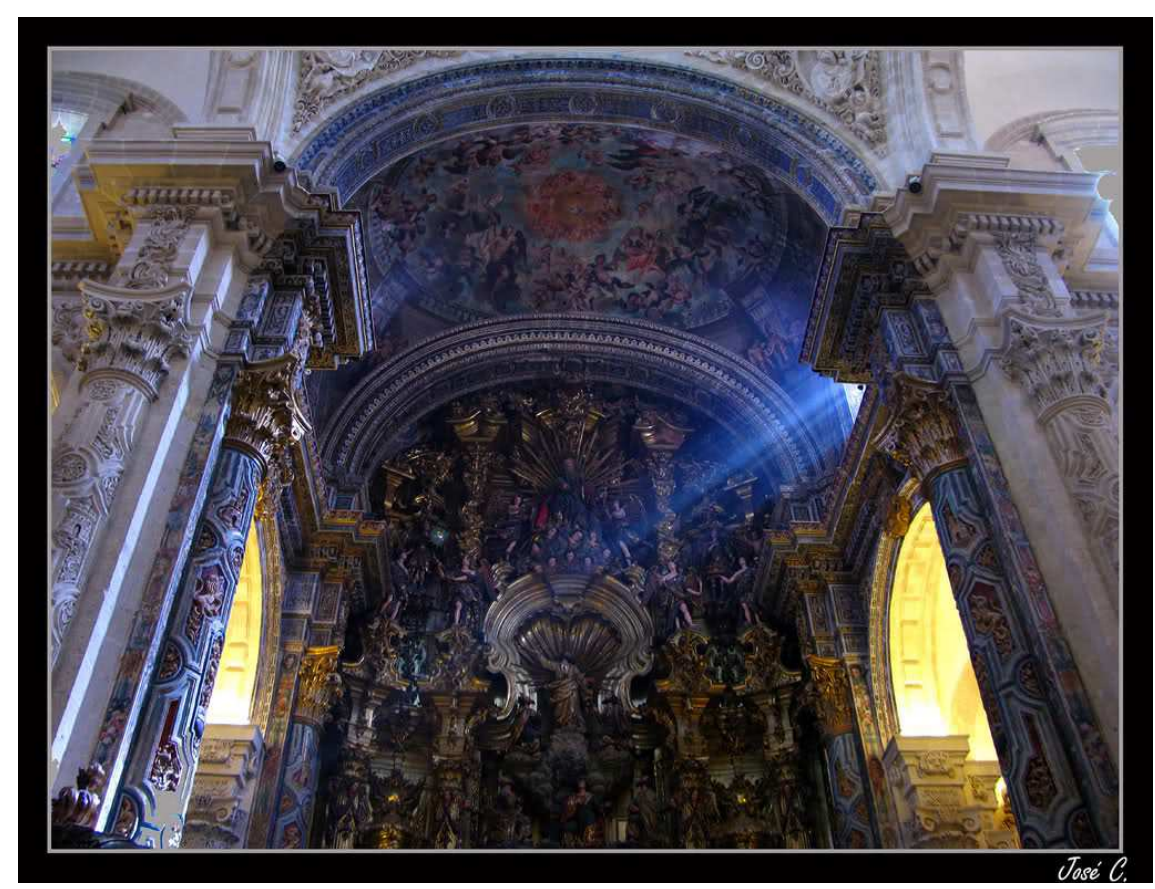

(Colegial del Divino Salvador. Sevilla, España.)

48 "Reception Room, Versailles." Encarta 2000. 
No hay que omitir recordar que este movimiento implicó una campaña ideológica concreta:

Una "revolución cultural en nombre de la ideología católica" (Giulio Carlo Argan, Storia dell'arte italiana, cit. en Historia del arte. 1539.)

Lo cual se deja ver en las expresiones más refinadas de la época en todo el orbe. Esto es, no sólo en Europa, sino también en América:

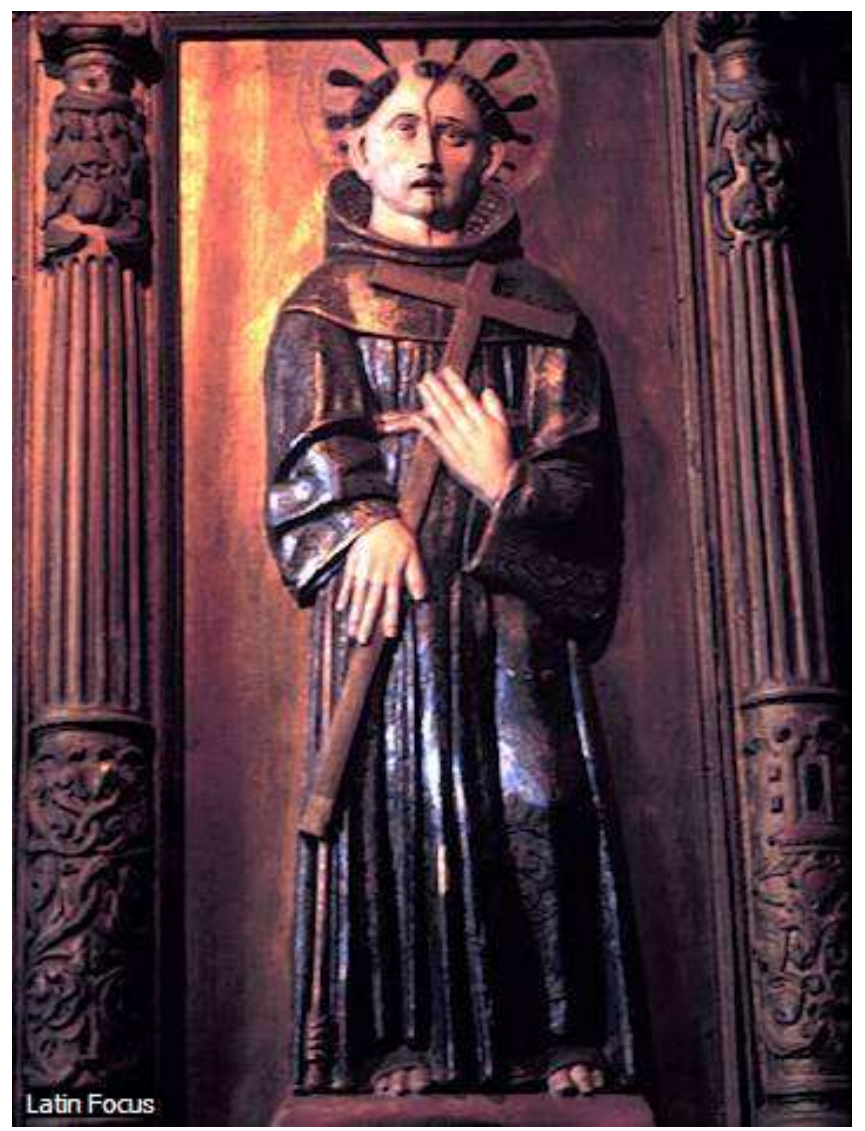

This painted wooden image of Fray Felipe de Jesús (about 1650) in the Cathedral of Mexico ranks among the most important pieces of 17th-century Mexican sculpture. The sculptor, whose name is unknown, shows the saint striding forward, his face locked in a tragic expression.

(Latin Focus.) $)^{49}$

Se incluye a los artistas plásticos más reconocidos (como Velásquez y Rembrandt):

49 "Fray Felipe de Jesús." Encarta 2000. 


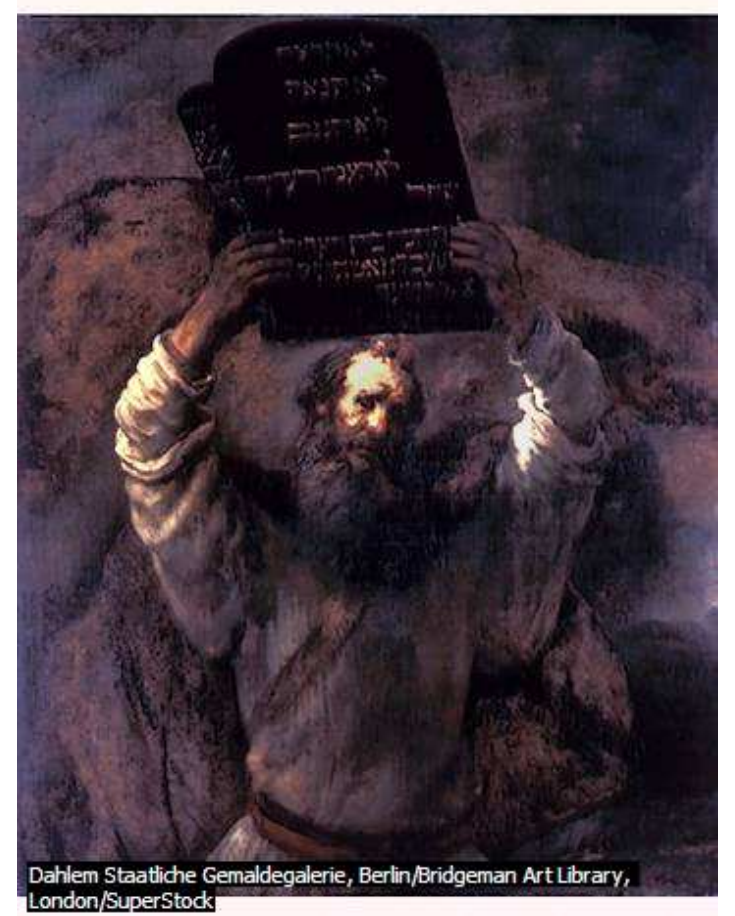

The Ten Commandments serve as the fundamental moral laws of Judaism and Christianity. According to the Old Testament, Moses received the Ten Commandments directly from God on Mount Sinai. He smashed the tablets upon returning from the top of the mountain when he found that the Israelites had begun to worship a golden calf. The Dutch baroque artist Rembrandt captured the wrath of Moses in his painting, Moses Smashing the Commandments (1659). (Dahlem Staatliche Gemaldegalerie, Berlin/Bridgeman Art Library, London/SuperStock. $)^{50}$

Y en sus escritores, como es claro en Cervantes, Lope y Calderón. Al respecto, no hay que olvidar que desde muy joven Calderón fue impregnado por la pasión religiosa. Su familia, como sabemos, lo presionó a abrazar la vida clerical (aunque al principio haya sido por razones económicas).

Nací en Madrid, y nací con suerte tan importuna que hasta un Ventura de Tal conocí (¡no más ventura...!).

Crecí, y mi señora madre, religiosamente astuta, como dando en otra cosa dio en que me había de ser cura.

El de Troya me ordenó de la primera tonsura, de cuyas órdenes sólo la coronilla me dura.

(Calderón, citado por Rodríguez Cuadros en Un discreto a voces.)

50 "Moses Smashing the Commandments." Encarta 2000. 
Mucho más adelante -y acaso después de múltiples periplos familiares, sociales, legales y profesionales- su propia conciencia lo hará aceptar con humildad (¿o resignación?) ese destino, mismo que le dio la seguridad económica para poder hacer otras cosas. El hecho es que, visto desde nuestros tiempos, no deja de conmover que antes de los treinta años de edad este poeta haya logrado crear una obra de perfil religioso tan emocionante como $\mathrm{El}$ príncipe constante.

\section{Lógica visual}

El manejo del espacio como escenografía y la abundancia de decorados son típicos del Barroco.

La intuición espacial puede constituirse en sentimiento del espacio, un espacio que, a veces a modo de retablo colosal, es testigo de la multiplicación de curvas y contracurvas, de órdenes y fragmentos de órdenes, de personajes sagrados y profanos, de estucos, de tablas doradas, de espejos y de mármoles policromos. (Historia del arte. 1542.)

En ese sentido, el catalán José Churriguera depuró un estilo propio que devino en escuela.

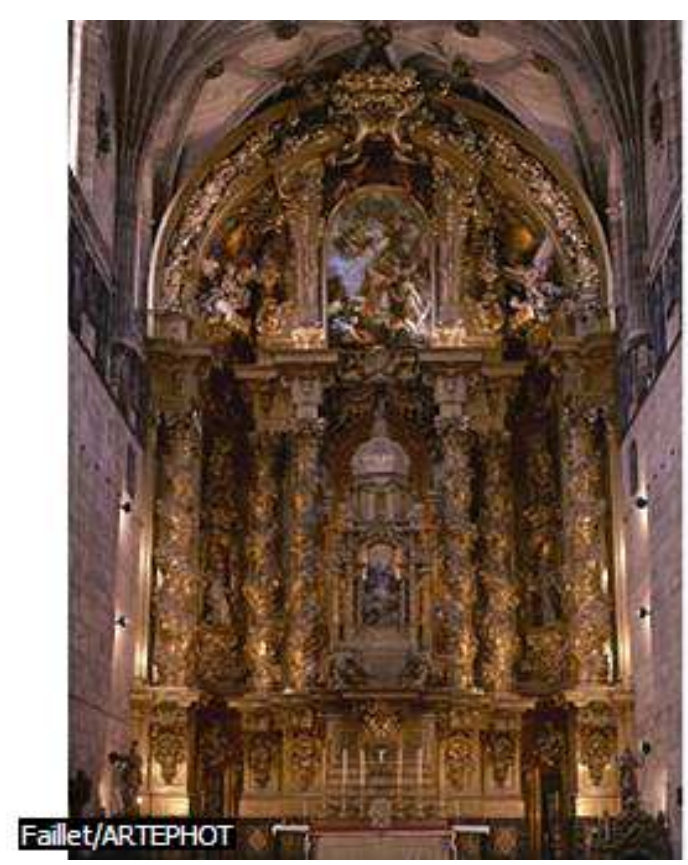

One of the best-known works by Spanish sculptor José Benito Churriguera is the Retablo (Altar Screen, 16931700) of the Church of San Esteban in Salamanca, Spain. This richly carved and gilded structure fills the east wall of the church. Its most distinctive features are its spiraling twisted columns, which became the hallmark of the Churrigueresque style. (Faillet/ARTEPHOT.) ${ }^{51}$

51 "Retablo, Church of San Esteban." Encarta 2000. 
La influencia estética del Barroco en las iglesias es bien conocida en todos los virreinatos latinoamericanos. Es difícil encontrar hoy a un habitante latinoamericano que no haya visitado una iglesia colonial con su respectivo retablo barroco: dorado, luminoso, abrumador en sus adornos infinitos, imponente en su carga y recarga de significados religiosos y profanos, festivo en sus homenajes, sagrado en sus premisas, gozoso en sus promesas, carnaval de signos. Resultaría interesante reflexionar qué tanto esta formación cultural, fruto de la evangelización, condicionó el gusto casi consensuado que tenemos en los países de este lado del Atlántico por lo espectacular y lo carnavalesco, es decir, por el Barroco. $^{52}$

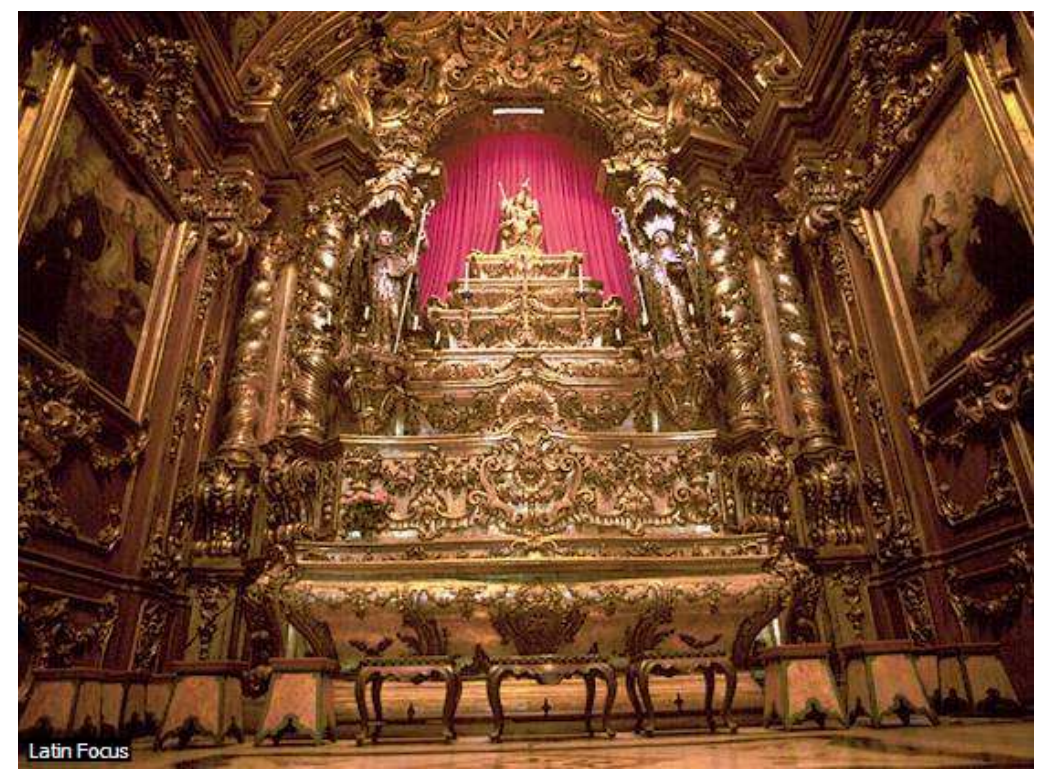

An important category of 17th and 18th-century Latin American sculpture was the the retablo (Spanish for "altarpiece"). Ornate retablos were often used to frame the altars of large Roman Catholic churches. This retablo, in the monastery of São Francisco in Salvador, Bahia, Brazil, features gilded architectural elements, carved sculpture, and painting.

(Latin Focus.) $)^{53}$

Qué más rebuscadamente barroco que la representación del templo barroco en una pintura barroca mostrando la escena de la complicada ceremonia eucarística. La comunión es el acto ritual más teatral de toda la liturgia católica, donde el protocolo místico transforma el vino y el pan en la sangre y el cuerpo de Cristo, fenómeno llamado transubstanciación. Es nuestro siguiente ejemplo:

\footnotetext{
${ }^{52}$ Un adelanto importante a este respecto lo hallamos sin duda alguna en el Laberinto de la soledad, de Octavio Paz.

53 "Retablo, Monastery of São Francisco." Encarta 2000.
} 


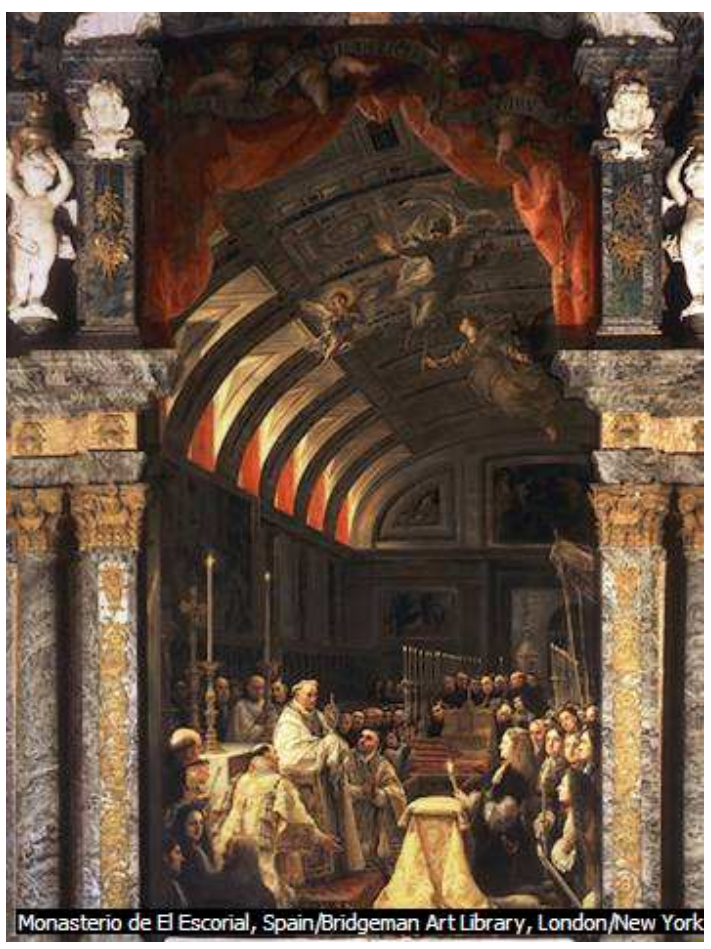

During the eucharistic liturgy in a mass, priests distribute the bread and wine of Holy Communion. The Roman Catholic faith teaches that the priest converts this bread and wine into the body and blood of Jesus Christ, a doctrine known as transubstantiation. By partaking of the bread and the wine, Roman Catholics affirm their union with Christ. In this late baroque painting by Claudio Coello, King Charles II of Spain receives Holy Communion.

(Monasterio de El Escorial, Spain/Bridgeman Art Library, London/New York.) ${ }^{54}$

Si lo sagrado inspiró el nacimiento del arte (recordemos las pinturas rituales de Altamira), ¿qué tanto ahora el arte -particularmente el Barroco como arma pastoral- inspiraría nuevos valores en lo sagrado?

El arte adquiere valores táctiles, corpóreos, que impresionan la retina del espectador. Lo trascendente se seculariza y se humaniza; para Milton, el espíritu era carne, del mismo modo que Bruno había afirmado que había un ser para la materia de las cosas corpóreas e incorpóreas. Este proceso es comparado por Sypher con el dogma de la transubstanciación, aunque planteándolo en el sentido inverso: "La devoción y el arte barroco modificaron y contaminaron la doctrina de la transubstanciación; la carne no se hizo espiritual, el espíritu se hizo carnal." Si la materia parece estar dotada de vida y energía propias, la curvatura del espacio parece contener, a priori, una idea de movimiento. (Historia del arte. 1542.)

Quizá el mejor ejemplo de esta transubstanciación estética en el ámbito de la escultura, es decir, de cómo lo espiritual deviene carnal, sea El éxtasis de Santa Teresa, de Bernini:

54"Eucharistic Liturgy." Encarta 2000. 


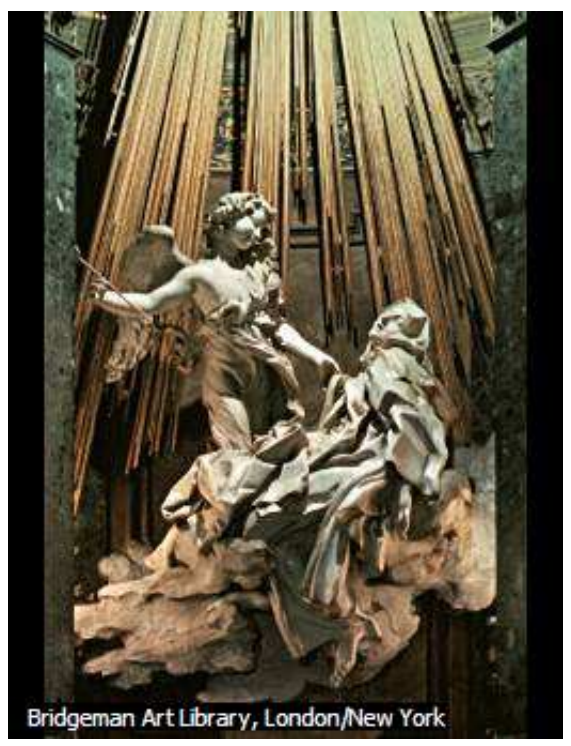

Ecstasy of Saint Teresa (1645-1652) by the 17th-century Italian sculptor Gianlorenzo Bernini was commissioned for the Cornaro Chapel of Santa Maria della Vittoria, Rome. The piece, made of marble, embodies the spirit of baroque sculpture with its dramatic tension, intricacy, and sense of movement. The light rays and arrow are made of bronze. (Bridgeman Art Library, London/New York.) 55

El mármol parece cobrar vida y moverse bajo la flecha y los rayos de bronce. Quizá un dramaturgo católico como Calderón se inspirara en obras como ésta y la que sigue. Obsérvese, junto con la anterior imagen, el reiterado uso en los pies de foto del adjetivo dramático: "dramatic tension", "dramatic light":

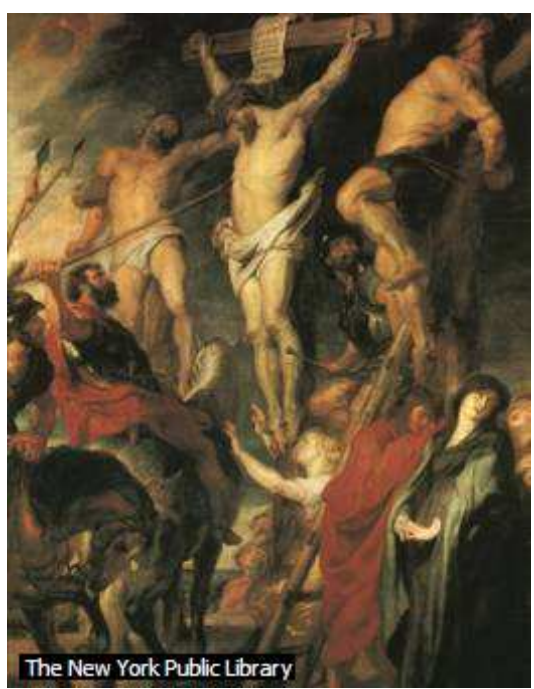

Christ on the Cross was painted by the 17th-century Flemish artist Peter Paul Rubens in 1620, at the height of his career. The sense of movement, swirling line, and dramatic light are characteristic of Rubens's distinctive style. This painting is now part of the collection of the Koninklijk Museum voor Schone Kunsten, Antwerp, Belgium. (The New York Public Library.) ${ }^{56}$

55 "Ecstasy of Saint Teresa." Encarta 2000.

56 "Christ on the Cross." Encarta 2000. 
Ambos ejemplos ilustran la transubstanciación como una experiencia estética donde la dimensión de lo sobrenatural, efectivamente, se materializa y se hace sensible. En ambos, igualmente, el arte visual se toma de la mano con el arte dramático.

\section{El Barroco español}

El Siglo de Oro Español es, a pesar de los rasgos en común con otras naciones, un capítulo único y diferenciado:

A diferencia de la cultura italiana, para la cual la historiografía sitúa el apogeo en la "edad de oro" en tiempos del Papa León X en el siglo XVI, la cultura española alcanza su apogeo en el Siglo de Oro después de recorrer la "edad de plata" del Renacimiento y a pesar de ser un periodo de decadencia política [o sea, el siglo XVII]. (Historia del arte. 1547.)

En ese sentido:

El barroco, al igual que el gótico tardío o el Romanticismo, sería un arte de crisis y depresión. (Historia del arte. 1540.)

En efecto, haber alcanzado el apogeo de un imperio donde no se ponía el sol y ser la máxima potencia económica y militar entre todos los países católicos, significa también el inicio de una decadencia irreversible, tanto en el nivel geopolítico (conflictos con América, Portugal, Cataluña, Francia, Inglaterra) como en el interior (una población agrícola pobre y mayoritariamente analfabeta).

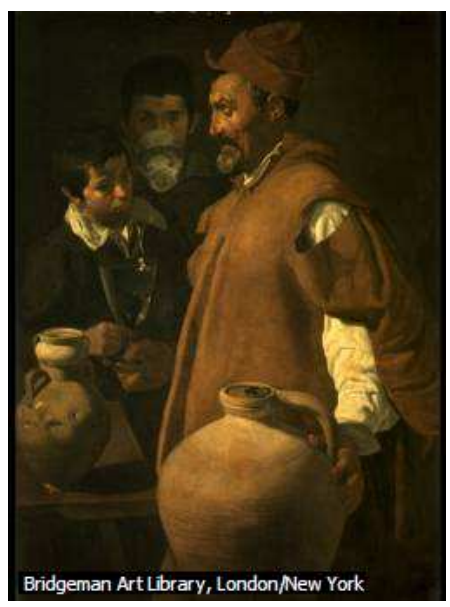

Water Seller of Seville was painted by the Spanish artist Diego Rodríguez de Silva y Velázquez in about 1619 or 1620, during the early years of his career. At that time, Velázquez was interested in portraying everyday life and ordinary people. The influence of Italian painter Caravaggio can be seen in the artist's use of chiaroscuro, the juxtaposition of dark and light. (Bridgeman Art Library, London/New York.) 57

57 "Water Seller of Seville." Encarta 2000. 
Véase en esta imagen la ropa humilde y rasgada del aguador, así como su severidad gestual, y el semblante desaseado y las prendas arrugadas de los jóvenes que lo flanquean. Se trata de personajes cotidianos del pueblo llano.

Si Calderón no conoció las obras de Rubens, al menos con toda certeza conoció las de Velásquez, pues coincidieron en tiempo y lugar (la Corte de Felipe IV y los pasillos del Alcázar, donde se sabe que conversaron sobre la posibilidad de un retrato que aparentemente nunca se realizó).

La pintura es la manifestación artística más notable del barroco español. La corte se convirtió en un centro artístico destacado, donde hubo una figura que brilló con luz propia, Velásquez. (Historia del arte. 1547.)

En la pintura inferior, una de las más famosas del autor, podemos ver integrados la familia del rey, un 'salón-estudio-galería’ del Palacio y al mismo Velásquez.

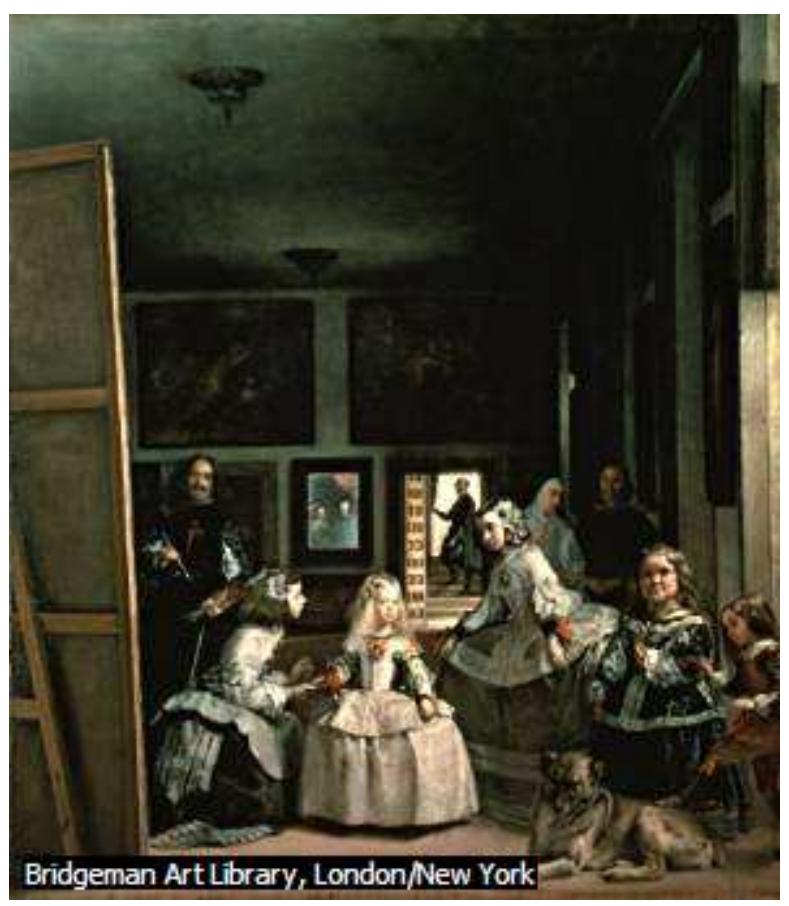

Las meninas (1656, Prado, Madrid) by Diego Rodríguez de Silva y Velázquez is considered one of the great paintings of all time. The central figure is Infanta Margarita, daughter of King Philip IV of Spain. The king and queen can be seen in the mirror on the far wall, and attendants include the two maids of honor for whom the painting is named. Velázquez includes himself, standing by a huge canvas, perhaps painting a portrait of the king and queen. The painting is cleverly constructed so that the viewer seems to be standing where the king and queen must be. (Bridgeman Art Library, London/New York.) 58

58 "Las meninas." Encarta 2000. 
La pintura española del Barroco trató todos los temas tratables.

Sin embargo, los encargos de la Iglesia siguieron siendo los más abundantes, y por lo tanto los temas religiosos fueron los más cultivados por los artistas hispanos. También se practicaron, en menor medida, otros géneros como el de la pintura mitológica, que tuvo sus ejemplos más sorprendentes, por la manera de abordarlos, en las obras de Velásquez. Los bodegones fueron frecuentemente tratados, pero los más característicos son las vanitas. Se trata de un tipo de pintura que incita a la meditación sobre la fugacidad de la vida, muy dentro del espíritu de la Contrarreforma, en la que aparecen calaveras, relojes, joyas, dinero, armas, en definitiva, bienes terrenales que desaparecen con la muerte. (Historia del arte. 1547.)

Efectivamente es en los vanitas donde más se relativizan las ambiciones mundanas como la riqueza, el poder y la belleza. El siguiente ejemplo es de Antonio de Pereda.

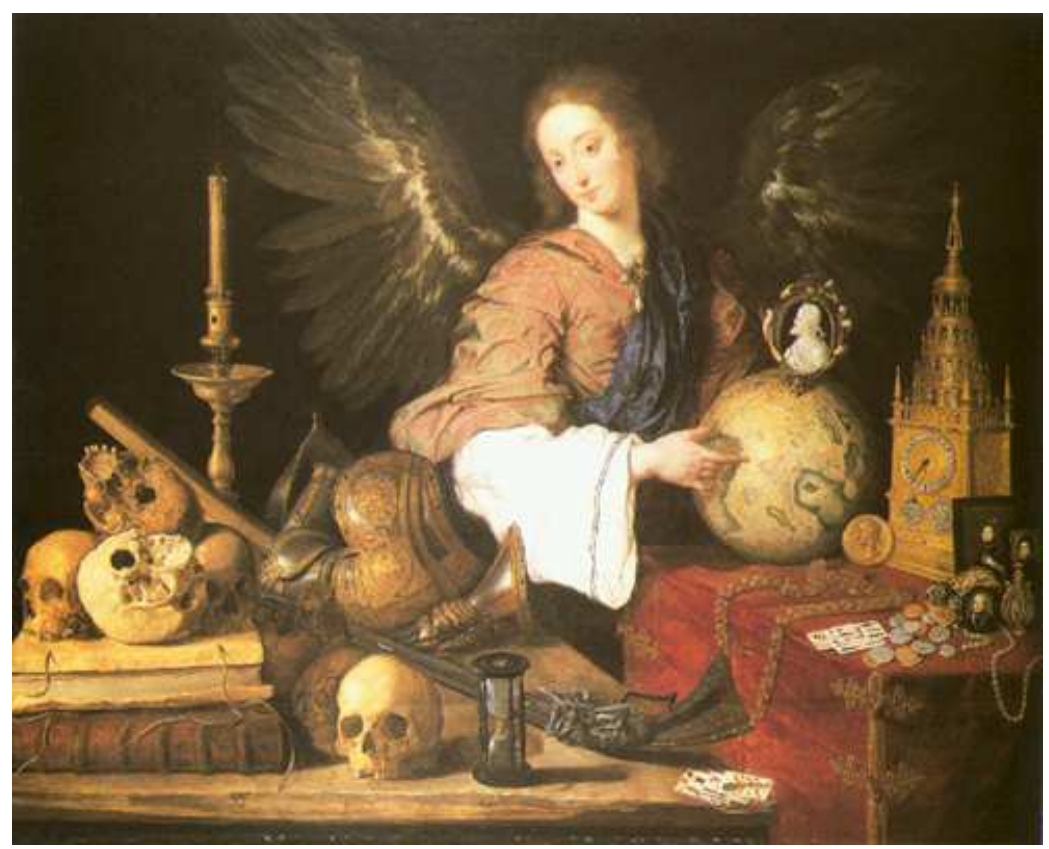

(Alegoría de la vanidad de la vida [c. 1640], por Antonio de Pereda. Museo Provincial de Zaragoza [España] y Kunsthistorisches Museum [Viena, Austria].) Sobre un globo terráqueo que simboliza la expansión del reino español (un imperio en el que "nunca se ponía el sol"), un ángel vuelto hacia el espectador sostiene un camafeo con el retrato de perfil de Carlos V. Ya había transcurrido casi un siglo desde la muerte del monarca. Las calaveras situadas al borde de la mesa, en primer plano, simbolizan los despojos de la existencia humana en vías de descomposición; su imperio no es imperecedero. "Nil omne" ("Todo es nada") reza el mensaje junto al reloj de arena. Pereda pintó el cuadro cuando España, bajo el reinado de Felipe IV (1621-1665), perdió su posición hegemónica, cayó en ruina económica, perdía Portugal y Cataluña (1640) y la guerra contra los Países Bajos (1648, Paz de Westfalia). (Schneider. Naturaleza muerta. 82-86.)

La pintura se toma la mano de un fragmento del conocido monólogo del personaje de Segismundo, una vez que acabóse su sueño de poder y riquezas, en la obra de Calderón La vida es sueño: 
Sueña el rey que es rey, y vive

Con este engaño mandando,

Disponiendo y gobernando;

Y este aplauso, que recibe

Prestado, en el viento escribe;

$\mathrm{Y}$ en cenizas le convierte

La muerte (¡desdicha fuerte!):

¿Qué hay quien intente reinar

Viendo que ha de dispertar

En el sueño de la muerte?

(Calderón de la Barca. La vida es sueño. II, 19.)

\section{Flores de la vida}

La siguiente imagen es un bodegón, del holandés Jan de Heem, que también ilustra mucho el sentido de fugacidad de la vida de las naturalezas muertas del Barroco. Esa sensación de estabilidad precaria es, desde luego, equivalente al carácter efímero del evento teatral, y tan dramática por cierto por su fácil asociación con las reflexiones existenciales a que incita su deprimente belleza. Póngase especial atención en las rosas, desde luego bellas, pero ya a punto de marchitarse, así como en las uvas, muchas de las cuales ya han iniciado su descomposición.

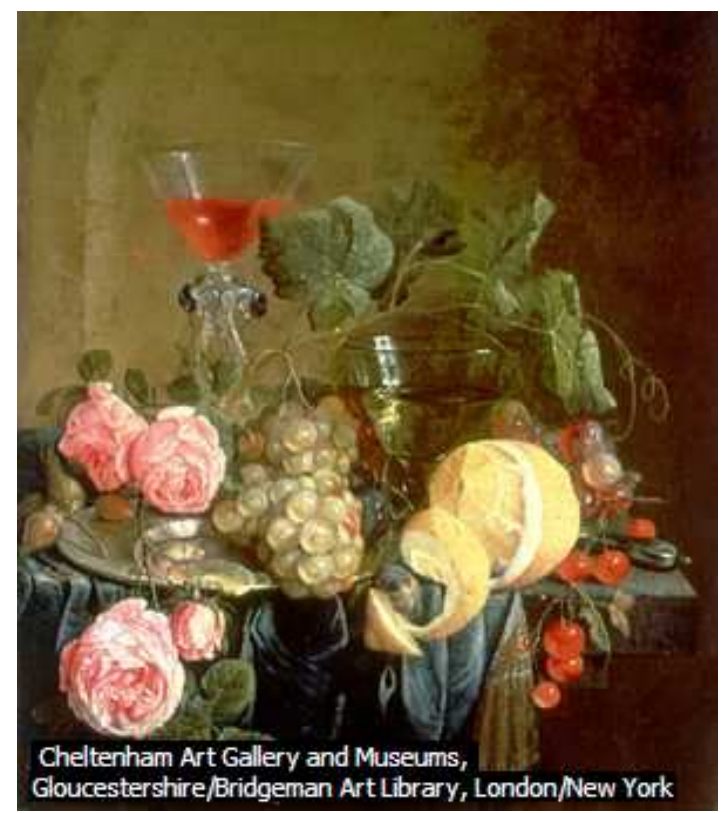

A twisting lemon peel, bright red berries, and dangling roses enliven this still life by Dutch painter Jan de Heem. De Heem's opulent compositions, brilliant colors, and sparkling highlights reinvigorated still-life painting in the Netherlands in the 17th century, a time when Dutch still lifes were typically limited to somber brown and grey tones. Fruit and Flowers is in the collection of the Cheltenham Gallery and Museum in Cheltenham, England, and is undated. (Cheltenham Art Gallery and Museums, Gloucestershire/Bridgeman Art Library, London/NY.) 59

59 "Fruit and Flowers." Encarta 2000. 
El Teatro mismo da cuenta de esta calidad icónica de la existencia:

En un entremés Juan Rana [...] hacía el Alcaide de aquel palacio -del Buen Retiro, donde en ese momento representaba- [...] y al entrar al salón se expresó así: «En esta mansión se cantan los versos y se actúan las comedias. El rey y la reina suelen sentarse allí, los grandes aquí, los señores allá, etc.» [...] Y vuelto al balcón en que acaso estaban sentadas dos princesas, dijo: «Considerad, os ruego, aquella pintura. ¡Cuán bien, cuán al vivo están pintadas aquellas dos viejas! Sólo la voz les falta, si hablaran las creyera vivas. En nuestro tiempo el arte de la pintura ha llegado a suma perfección». (Caramuel citado por Rozas.)

En El príncipe constante, un diálogo entre el infante Fernando y la princesa mora Fénix se vale de la misma técnica visual de las alusiones naturalistas de los bodegones y vanitas para tratar sobre la finitud de la existencia en una interlocución apoyada sobre dos elocuentes sonetos alegóricos. Aquí los convencionalismos de la palabra son dispuestos en toda su potencia sin la necesidad de efectos mecánicos especiales (tramoyas) para lograr una contundente crítica a lo inútil de la vanidad y un decoroso lucimiento actoral.

FERNANDO: Para presumir por ellas las flores habrán venido.

Éstas, que fueron pompa y alegría despertando al albor de la mañana, a la tarde serán lástima vana, durmiendo en brazos de la noche fría.

Este matiz, que al cielo desafía, iris listado de oro, nieve y grana, será escarmiento de la vida humana. ¡Tanto se emprende en término de un día!

A florecer las rosas madrugaron, y para envejecerse florecieron.

Cuna y sepulcro en un botón hallaron.

Tales los hombres sus fortunas vieron.

En un día nacieron y expiraron; que pasados los siglos, horas fueron.

FÉNIX: Horror y miedo me has dado, ni oírte ni verte quiero; sé el desdichado primero de quien huye un desdichado.

FERNANDO: ¿Y las flores?

FÉNIX: Si has hallado jeroglíficos en ellas, deshacellas y rompellas sólo sabrán mis rigores.

FERNANDO: ¿Qué culpa tienen las flores? FÉNIX: Parecerse a las estrellas.

FERNANDO: ¿YYa no las quieres? 


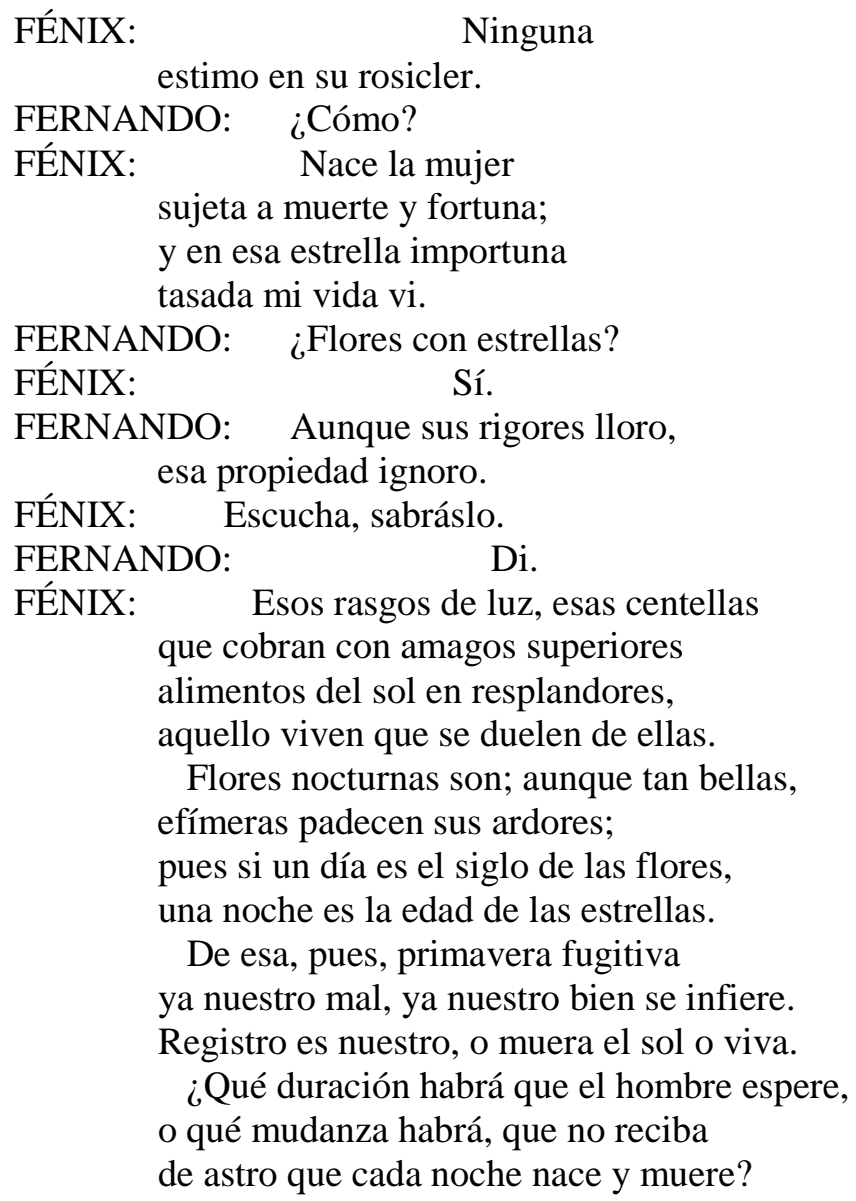

La manera en que son nombradas las flores y las estrellas y su relación de profunda semejanza con la vida y la belleza volátiles hace de ambos sonetos juntos una de las escenas más emblemáticas del teatro trágico (en un sentido filosófico) de Calderón.

\begin{abstract}
Alcances
La complejidad, diversidad y conflictos del Barroco hacen de él un periodo polisémico y también una corriente teatral en todo el sentido del término: espectacular, excesivo, dramático, emotivo.
\end{abstract}

Se ha intentado huir de una definición unívoca del barroco para incidir en el carácter complejo del lenguaje. Desde este punto de vista, el arte del siglo XVII, heredero del criticismo materialista hacia el modelo clásico, aparece como un fenómeno plural en una Europa que había dejado de ser unitaria. La diversificación de las experiencias religiosas, que van desde el misticismo más exaltado hasta el racionalismo más estricto, las alternativas del protestantismo y del catolicismo, las distintas maneras de hacer visibles los contenidos del poder, configuran experiencias visuales tan diversas y aun opuestas como las de Bernini, Le Brun, Velásquez o Rubens. (Historia del arte. 1547.) 


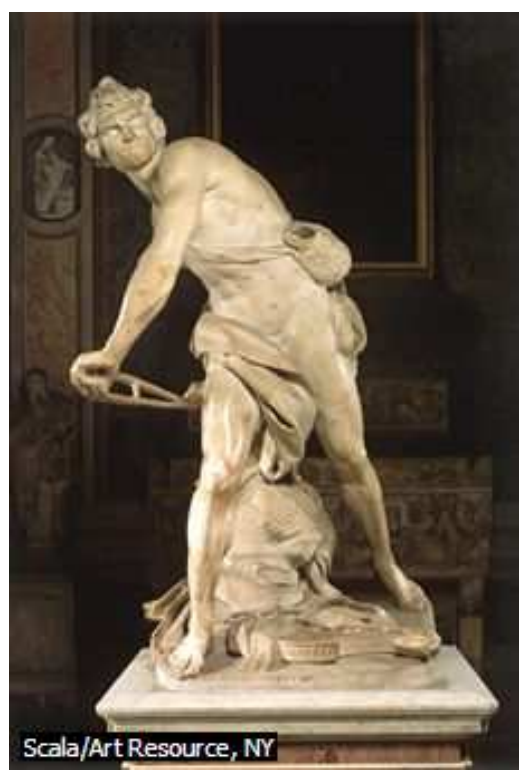

Art of the baroque era is characterized by an emphasis on movement and emotional drama. Italian baroque sculptor Gianlorenzo Bernini chose to show the biblical figure of David (1623?, Galleria Borghese, Rome) at the moment of maximum physical contortion, concentrated energy, and emotion - as he hurls the stone at the giant Goliath.

(Scala/Art Resource, NY.) 60

Hoy podemos comparar en el Barroco obras sobre la cotidianidad, la historia sagrada y la mitología clásica que combinan las técnicas más convencionales y rigurosas con la máxima libertad y modernidad.

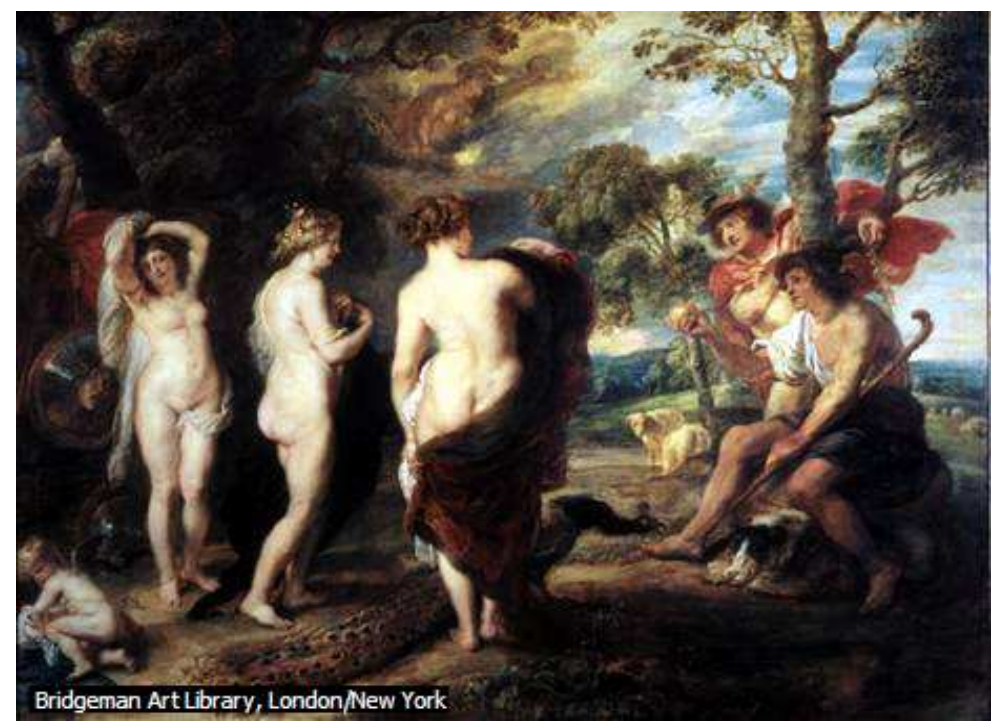

The Judgment of Paris (1635-?) was painted by Flemish baroque artist Peter Paul Rubens. The painting is based on the Greek myth in which the shepherd Paris is asked by three goddesses to decide which of them is the most beautiful. According to mythology, this is the incident that sparked the legendary Trojan War. The sense of agitated movement, dramatic light, and earthy figures in the painting characterize Rubens's work. (Bridgeman Art Library, London/New York.) ${ }^{61}$

60 "Bernini's David." Encarta 2000.

61 "The Judgment of Paris." Encarta 2000. 
En el siglo XVII, esta atmósfera de ultramodernidad (como también es explicada la posmodernidad de nuestros días) no pudo ser pasada por alto por dramaturgos, autores de comedias (empresarios) y representantes. En estos últimos, el crecimiento profesional -la necesidad de aprender y actualizarse para hacerse más competitivos y rentables- promovió, por ejemplo, una evolución del léxico hasta lograr hacer denominar de varias maneras su oficio.

De seis modos diferentes he observado que se denomina a la profesión en esta época: representante, representador (variante recogida en el Tesoro de Covarrubias), farsante, comediante, histrión y, naturalmente, actor. Pero quiero llamar la atención sobre el escaso uso de este último término que califica específicamente, según el Diccionario de Autoridades, al que representa con primor o, como diría Zabaleta, a los que "refinan el acto que hacen". Por ello el Pinciano sustenta la separación neta entre el rudo histrión (en el sentido de falta de juicio, de técnica, de conocimiento) de "movimientos torpes y deshonestos", y el actor que asume facultades espirituales, y cuya obra es "de suyo más útil y honesta" que la de los volantineros. (Rodríguez Cuadros. "Registros y modos..." 39.)

Nótese la confirmación de un equivalente específico de la transubstanciación para el oficio actoral al hablarse por fin de sus facultades espirituales y de su obra "más útil y honesta" (en tanto que función social), una vez alcanzado el nivel del virtuosismo. Algo muy digno de mención dado el contexto de estigmatización moral en que vivía entonces (y siempre) el actor. Para ser más consecuentes, habría que reconocer la actualización o modernización de la frase mística: "Y el Verbo [la palabra del poeta dramático] se hizo carne [en la actuación teatral]", para explicar el acceso -o el regreso- del trabajo de interpretación actoral a la dimensión de lo sagrado. Jerzy Grotowski, un director teatral contemporáneo lo explica en términos semiológicos:

Sabemos que el texto per se no es teatro, que se vuelve teatro por la utilización que de él hacen los actores, es decir, gracias a las entonaciones, a las asociaciones de sonidos, a la musicalidad del lenguaje. (Grotowski. Hacia un teatro pobre. 16.)

Vista de otro modo, la transubstanciación es también la tarea del actor teatral que, en el ritual de la representación, transforma todo lo que toca, pisa, viste y nombra. Así, el espíritu de la obra dramática, la intentio, se vuelve carne viva en el espacio escénico. 
El actor transforma, mediante el uso controlado de sus gestos, el piso en mar, una mesa en un confesionario, un objeto de hierro en un compañero animado, etc. (Grotowski. Hacia un teatro pobre. 16.)

La concentración de las potencias espectaculares de la obra de Calderón en la persona y labor del actor no fue un ejercicio ajeno al dramaturgo del siglo XVII. Es más, en 1629 en Madrid aún no se contaba con los escenógrafos italianos ni con el aparato técnico del Palacio del Buen Retiro. El actor barroco debía cargar, por lo tanto, con todo el peso de las sugerencias del texto, principalmente a partir de una interpretación oral fina y elocuente.

Si bien los cambios [escenográficos] afectan a la representación en su conjunto, hemos de tener en cuenta que numerosos recursos nacidos en la época de Lope siguen manteniéndose vigentes (gestualidad de los actores, vestuario generalmente contemporáneo se tratara de la obra que se tratara, etc.) Otros, aun manteniéndose, se desarrollan cuantitativamente de acuerdo con los gustos de la época: pensemos en todo el conjunto de lo que podemos llamar convencionalismos de la palabra (apartes, conversaciones dobles, alusiones al público...); se trata de recursos que Calderón maneja con suma habilidad. (Sirera: 71.)

También ya hemos visto cómo el actor calderoniano era capaz de hacer de su cuerpo una máquina altamente eficaz en cuanto a la gestualidad y la capacidad de mover a intensas emociones cuando mencionamos cómo "ver a Antonio de Prado en el personaje de Carlos $\mathrm{V}$, ya viejo, es recomendable, pues no hay quien 'no salga edificado y movido'." (Rozas. Sobre la técnica del actor barroco. Artículo online.) En otro caso...

Caramuel -y lo traduce libremente el Padre Alcázar- cuenta como María Riquelme: «mudaba el color del rostro con admiración de todos. Si se contaban en las tablas cosas dichosas y felices, las escuchaba bañada en color de rosa, y si ocurría alguna circunstancia infausta se ponía al punto pálida». (Rozas. Sobre la técnica del actor barroco. Artículo online.)

Transubstanciación, éxtasis y acaso catarsis fueron un pan que antes del Barroco sólo los griegos degustaron.

En el Barroco, dramaturgo-actor-espectador son una cadena en la que cada uno de los tres eslabones vive el éxtasis y la alienación. Por eso, algún autor, como Cubillo de Aragón, aconseja no ir a ver los horrores del teatro después de las preocupaciones de cada día, porque era añadir a la mente nuevos problemas. La opinión de la mayoría, sin embargo, no era ésta, sino que creían que la enajenación, el entretenimiento, era un consuelo, siempre 
dentro de ese hacer aristotélico. Dice Cosme Gómez: “Aquí se hace mesa de manjares, y se ministran las medicinas para sacar la risa de los más tristes hipocondrios; la música consuela, los bailes deleitan, las trazas suspenden, los versos admiran, los amores enternecen, las traiciones ofenden, los desprecios lastiman, las gracias alegran, y todo entretiene." (Rozas. Sobre la técnica del actor barroco. Artículo online.)

Y es que en el siglo de Calderón ni la literatura dramática ni el espectáculo teatral pueden deslindarse de los máximos alcances del arte Barroco:

La obra de arte pasa a ser en su totalidad, como organismo unitario y vivificado en todas sus partes, símbolo del universo. Cada una de estas partes apunta, como los cuerpos celestes, a una relación infinita e ininterrumpida; cada una contiene la ley del todo; en cada una opera la misma fuerza, el mismo espíritu. Las bruscas diagonales, los escorzos de momentánea perspectiva, los efectos de luz forzados: todo expresa un impulso potentísimo e incontenible hacia lo ilimitado. Cada línea conduce la mirada a la lejanía; cada forma movida parece quererse superar a sí misma, cada motivo se encuentra en un estado de tensión y de esfuerzo, como si el artista nunca estuviera completamente seguro de que consigue también expresar efectivamente lo absoluto. (Arnold Hauser. Historia social de la literatura y el arte I. 507.)

En esta lógica estética percibimos un ánimo de experimentación, aprendizaje y sincretismo constante, una necesidad inevitable de ponerse al día, de modernizarse, afanes todos tan obsesivos y adictivos que nos recuerdan a nuestros propios días. En efecto, mucho de todo cuanto define al Barroco coincide con lo que determina la condición posmoderna del siglo XX y principios del XXI.

En la posmodernidad se enfatiza la interpretación por encima de la intención original [obsérvese la actualización y nuevo enfoque de los autores a los mitos clásicos], se valoriza la parodia sobre la originalidad [La fiesta de Baco o Los borrachos de Velásquez], y se prefiere la incertidumbre sobre la verdad irrefutable [El éxtasis de Santa Teresa, ¿es o no es un orgasmo?] Es un espacio propicio a la ironía [las bellas y mortales naturalezas muertas y los vanitas], la autorreferencialidad [los autorretratos de Rembrandt y Velásquez] y la paradoja [la expresividad rica y ostentosa en medio de un contexto socioeconómico en crisis]. (Lauro Zavala. La precisión de la incertidumbre. 78.)

En otras palabras, con ciertas salvedades (la fe religiosa sería la más importante) y coincidiendo con muchos estudiosos (Lauro Zavala es uno de ellos), la Posmodernidad es una "Era Neobarroca”. El artista plástico contemporáneo Benjamín Rodríguez confirma: 
El Barroco - comenta el artista- no podría reflejar con más claridad la época en que vivimos, porque estamos viviendo una serie de problemas que se deben sobre todo a la tecnología, que nos crea un conflicto interior. [...] Nunca [tanto como en nuestros días...] el hombre se había acercado interiormente al concepto del Barroco, pues [el mundo] nunca había sido tan complicado como lo es ahora. Aunque es un concepto de hace muchos siglos, el barroco se adecua perfectamente bien al lenguaje de lo que queremos decir sobre la humanidad de esta época. (En entrevista con Rosario Pinelo: "Benjamín Rodríguez: Barroco", en Tiempo Libre. Del 31 de marzo al 6 de abril de 2011. XXXI. 1612. 41.)

Entendiendo la Posmodernidad como un nivel de la Modernidad del siglo XX donde ésta se cuestiona y se critica a sí misma, podremos comprender la aparición de posturas Neobarrocas contradictorias, desde los excesos de los pastiches, collages y rebuscamientos del Pop-art y del Expresionismo Abstracto (excesos equivalentes a las desmesuras y extravagancias del Churrigueresco y el Rococó de los siglos XVII y XVIII), hasta una corriente antagonista que, en su oposición, opta por reducir las formas expresivas a las mínimas elementales: el Minimalismo.

En sus principios de austeridad y discreción, el Minimalismo es un polo paradoxal de interés en el marco estético del Neobarroco contemporáneo por cuanto les ha permitido a críticos y creadores de hoy interpretar y recrear con pocos recursos materiales la literatura y el teatro del Siglo de Oro sin traicionar su espíritu original, mismo que nosotros consideramos fundamentado en la dramaturgia y en el trabajo del actor. Así pues, debemos entender que aunque en el contexto de producción de El príncipe constante el autor, el público y el actor estaban listos teórica y espiritualmente para vivir una revolución estética espectacular, ésta comenzaría desde su potencia dramatúrgica e interpretativa (como vimos con su uso de los convencionalismos de la palabra en los sonetos de Fernando y Fénix), tal y como lo redescubrió Grotowski en el siglo XX para su propio montaje Postmodernista, es decir Neobarroco, despojado de efectos técnicos especiales: Minimalista.

Todo esto será pertinente para resolver el problema de una nueva interpretación teatral: una puesta en escena propia con la perspectiva Neobarroca del Minimalismo. 


\section{CApítulo V: AUSTERIDAd}

\section{El minimalismo teatral neobarroco ${ }^{62}$}

Nuestra estrategia de análisis de El príncipe constante presupone que su mejor lectura está directamente vinculada con su naturaleza de partitura representacional y, por lo tanto, con su puesta en escena, entendiendo ésta como el desarrollo en vivo de una lectura actoral. En este sentido, consideramos que una lectura escénica fiel tanto a su contexto de producción en general como a la intentio autoral en particular puede generarse en el marco Neobarroco del Minimalismo teatral contemporáneo. En este apartado describiremos los orígenes y las bases conceptuales de una actitud creativa creciente basada en la austeridad y la discreción ("Less is more", dictó Ad Reinhardt [1975]) que, si bien comenzó en las artes plásticas y la arquitectura, se extendió a otras formas de expresión y hoy alcanza en el teatro a los estilos de escritura dramática, de puesta en escena y de formación actoral, dando en denominarse "Minimalismo Teatral".

En el escenario, menos es más. Así es el teatro; un instrumento retorcido en el que hay que soplar con toda el alma para obtener al menos un tenue sonido adecuado. No más, sólo que para eso hace falta un gran aliento. (Luis de Tavira y Stefanie Weiss. Ser es ser visto. 27.)

¿Qué es, en qué consiste, de dónde, de quiénes viene, hacia dónde se dirige y cómo nos puede servir para nuestra puesta en escena? son algunas preguntas que intentamos resolver aquí. Para comprender adecuadamente el concepto estético del minimalismo, es decir, el proceso reduccionista que llevaría a las artes, sobre todo las visuales, hacia sus estructuras más simples y esenciales (todo lo contrario al Barroco del siglo XVII), comenzaremos por revisar brevemente sus antecedentes en el arte abstracto, de modo que, eventualmente, aterricemos en una noción de lo que hoy es el minimalismo teatral. Desde comienzos del siglo XX, se reconoce a Wassily Kandinsky (1866-1944) como fundador de la abstracción estética en la pintura, es decir, como padre del arte abstracto. En la siguiente pintura, obsérvese la falta de elementos figurativos u objetuales.

\footnotetext{
${ }^{62}$ Este ensayo apareció en su forma original en mi tesis de maestría Perspectivas sobre Samuel Beckett y Heiner Müller con base en la creatividad minimalista. (México: UNAM, 2003.) Aquí lo hemos ampliado para explorar su viabilidad en la producción de El príncipe constante del Laboratorio Libertad.
} 


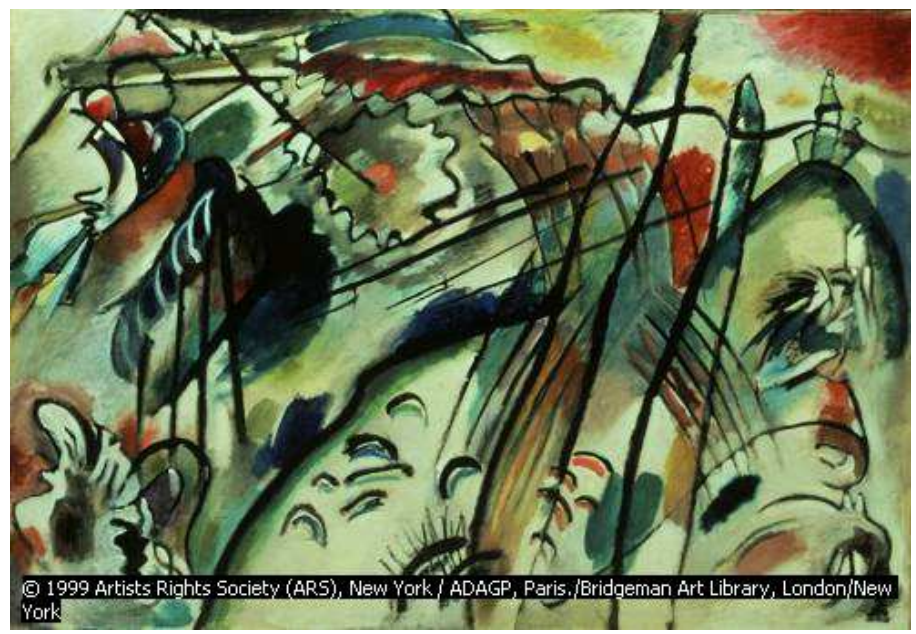

Improvisación 28, segunda versión (1912.)

Kandinsky liberó al signo visual de la encomienda de ser mera representación de la realidad. Buscaba trascender la pintura figurativa al dejar de imitar a la naturaleza.

Otro ruso, Vladimir Tatlin (1885-1953), aclaró y profundizó los fundamentos de la nueva estética propuesta por Kandinski. Como lo describe Anna Moszynska: "Yet in a manifesto published with his wife, Xana Boguslavskaya, at the 'O-IO' exhibition, he declared that 'a picture is a new conception of abstracted, real elements deprived of meaning'." (1990, Abstract Art: 74.)

La ruptura entre significante y significado no sólo se daría en las artes visuales. La influencia sería básica, a partir de este momento, para todos los creadores de vanguardia. Moszynska prosigue: "The repudiation of meaning, as well as the commitment to 'real elements', indicates an early attempt to justify the abstract art work as a self-sufficient entity, with no further motive" (1990: 74.)

Otros autores importantes que pueden considerarse como precursores del minimalismo son el ruso Kasimir Malevich (1878-1935), que se apoyó en la supremacía del sentimiento sobre cualquier otra consideración artística (suprematismo), reflejada en su famosa composición de un cuadrado negro sobre fondo blanco; y el holandés Piet Mondrian (1872-1944), quien creó una serie de pinturas casi idénticas inspirándose en la idea de la armonía universal (neoplasticismo). Sin embargo, a pesar de sus asociaciones conceptuales con el minimalismo, estos pintores están más relacionados con el cubismo, creado por Pablo Picasso (1881-1973) y Georges Braque (1882-1963), de donde abrevan. 
La idea de la obra autónoma avanza durante el siglo $\mathrm{XX}$, hasta llegar por fin al minimal art. "This formalist point of view - an abstract 'art for art' sake philosophy- was to recur later with Concrete art in the 1930s and Minimal art in the 1960s" (Moszynska 1990: 74.) Según la autora, un manifiesto artístico de vanguardia de tiempos de la Primera Guerra Mundial es precursor directo de la ideología plástica minimalista. El primer y único número de la revista Art Concret, publicado en París en 1930 por Theo van Doesburg, no proponía nada nuevo para el arte abstracto (la autosuficiencia de la obra de arte ya había sido discutida desde 1924 por la revista polaca Blok, y mucho antes en los círculos constructivistas rusos), pero estaba escrito en la lengua más usada por los creadores vanguardistas, el francés (lo cual implicaba mayor difusión), y oponía claramente la abstracción a la naturaleza. Los puntos del manifiesto eran:

1. Art is universal.

2. The work of art should be entirely conceived and formed by the mind before its execution. It should receive nothing from Nature's formal properties or from sensuality or sentimentality...

3. The picture should be constructed entirely from purely plastic elements, that is to say, planes and colours. A pictorical element has no other significance than 'itself', and therefore the picture has no other significance than 'itself'.

4. The construction of the picture should be simple and controllable visually.

5. Technique should be mechanical, that is to say, exact, anti-impressionistic.

6. Effort for absolute clarity.

(en Moszynska 1990: 104-106.)

Las estéticas de vanguardia, y más concretamente las de arte abstracto, influirán en todo el pensamiento moderno, desde Ortega y Gasset (1925, La deshumanización del arte) hasta Umberto Eco ("El problema de la obra abierta”, en Eco 1970.) Para algunos se trata de una moda, para otros, de una crisis y, para otros más, de productos que buscan la participación activa del espectador en su creación misma, en su significación. ${ }^{63}$ Para Lyotard ( $L a$ posmodernidad explicada a los niños, 1986), por ejemplo, estas obras generan su propia estética en el acto mismo de su producción. Para Jameson (El posmodernismo o la lógica cultural del capitalismo avanzado, 1991), se trata de una etapa cultural lógica derivada del capitalismo.

\footnotetext{
${ }^{63}$ Es lo que en teoría de la recepción denominamos implicación del lector.
} 
Poco a poco, el rompimiento con el figurativismo (o imitación de la naturaleza) se fue haciendo una moda entre las corrientes artísticas, hasta que el arte abstracto se hizo cotidiano. Al no haber un nuevo camino a la vista, los artistas se dedicaron a explotar al máximo sus capacidades expresivas, llegando a los estilos del expresionismo abstracto (encabezado por Paul Jackson Pollock) y del pop art (encabezado por Andy Warhol.)

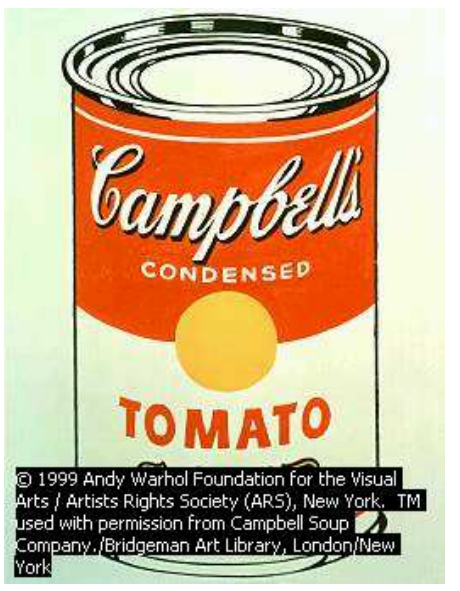

Campbell's Soup Can (Warhol, 1962.)

Los signos del maximalismo, es decir, de la sobreexplotación de los recursos expresivos del autor en Warhol, Pollock y otros autores, se ven en esos momentos impulsados por el comercio a través de la oferta, la demanda y la reproducción masiva del producto artístico, así como apoyados por los mass media, con su infraestructura de promoción y difusión publicitaria (comercial, no cultural.) Estos signos se mantienen vigentes en nuestros días (momento al que llamamos época postindustrial.)

Aunque Umberto Eco no utiliza el término "maximalismo" en La estructura ausente (1986), sí menciona el fenómeno de los mensajes con cuerpo demasiado grande para contenidos pobres de significado, que puede funcionar para explicar y definir lo que es el maximalismo:

Ya lo hemos visto: la historia, con su vitalidad voraz, vacía y llena las formas, las priva y dota de significado; y ante la inevitabilidad de este proceso no nos quedaría otro recurso que fiarnos de la sabiduría instintiva de los grupos y las culturas, capaces de hacer revivir cada vez las formas y los sistemas significantes. Pero quedamos algo perplejos y tristes ante unas formas inmensas que para nosotros han perdido su poder significante original y parecen (referidas a los significados más débiles que les inoculamos) mensajes demasiado complejos respecto a la información que transmiten. En la vida de las formas pululan estos 
gigantes sin sentido, o con un sentido demasiado pequeño para un cuerpo tan grande, gigantes que solamente se pueden justificar infundiéndoles unos sentidos desmesurados, fabricando para ellos al buen tuntún unos códigos de enriquecimiento injustificables (y nos encontramos de nuevo con aquellas fórmulas de la Retórica, en el sentido estricto y negativo del término, como los "cuarenta siglos" de las pirámides.)

(Eco 1986: 352, 353.)

Para el criterio de algunos creadores, como Ad Reinhardt (1975, Art as Art), el explosivo ímpetu expresivo, es decir el maximalismo, de Warhol y Pollock, reflejaba una degradación de los mejores valores del arte y, por lo tanto, había que preguntarse cómo reencontrar esos valores. La respuesta que encontraron se oponía claramente a las propuestas maximalistas, e implicaba austeridad, discreción y anonimato.

$\mathrm{Al}$ arte plástico minimalista norteamericano se le conoce también como arte mínimo o minimal, o movimiento minimalista, systemic painting, ABC Art, serial art o sencillamente minimalismo. Sabemos que el minimalismo inició como "una tendencia en pintura, y más en especial en escultura, que surge durante la década de 1950 en la que sólo se utilizaban formas geométricas elementales" (Ivers et al. 1992, Diccionario de arte: 473.) Poco a poco el minimalismo se fue consolidando: "El arte minimal se consolidó en EU a partir de 1965 sugiriendo un proceso reduccionista que llevaría la pintura, pero sobre todo la escultura, hacia sus estructuras más simples y esenciales" (Historia del arte [Últimas tendencias, vol. 16] 1997: 2898.) A las estructuras más simples y esenciales de la plástica se les nombró "estructuras primarias". A partir de entonces, el minimalismo se fue expandiendo, muy lentamente, entre críticas y rechazos, como una alternativa estética más allá de otras vanguardias, avanzando en contra del maximalismo, entendido como abuso de los recursos expresivos, de otras propuestas como el pop art y el expresionismo abstracto.

Los artistas minimalistas comparten principios... "de economía expresiva y simplicidad, así como la obsesión por el orden, la pureza plástica y la claridad" (Historia del arte [obra citada] 1997: 2898.) Acerca de creadores plásticos minimalistas como Carl Andre, Donald Judd y Frank Stella encontramos la siguiente información:

Carl Andre (n. 1935): "Realiza sus obras amontonando piezas de productos comerciales, tales como planchas de poliestireno, ladrillos, bloques de cemento, piezas magnéticas, etc., según un sistema modular matemáticamente organizado y sin ensamblaje ni adhesivos" (Ivers et al 1992: 25.) Por su cuenta, la obra de Donald Judd (n. 1928): “se 
compone específicamente de cajas de acero inoxidable o hierro pintado, o sencillas formas similares, situadas unas junto a otras sin connotaciones emocionales" (Ivers et al 1992: 375.) Frank Stella (n. 1936) nos dice de sus trabajos: "What you see is what you see" ("Minimal art", en Encarta 2000), dando a entender que la mera experiencia visual (aistesis) de una pintura es más importante que cualquier interpretación.

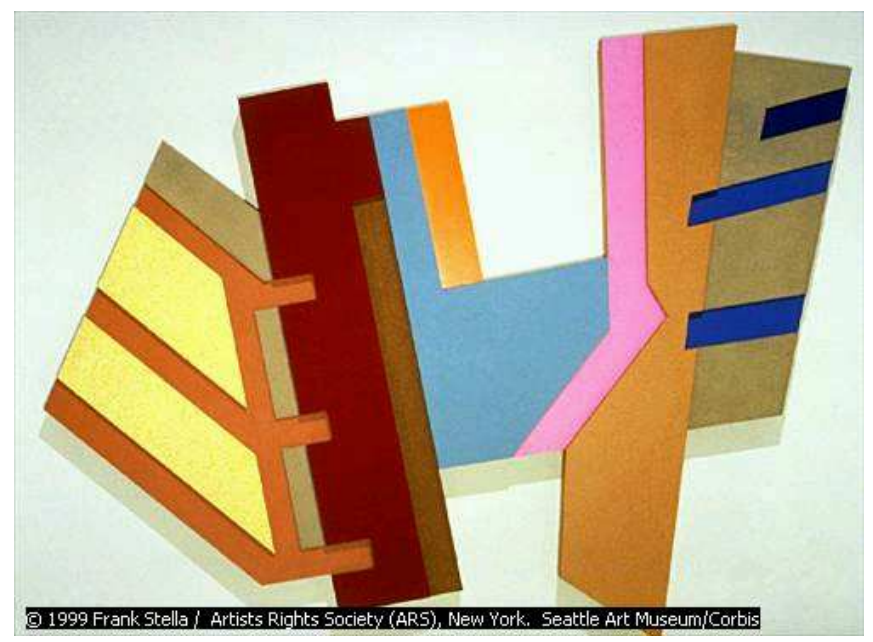

Rozdol II (Frank Stella, 1973.)

Otros artistas minimalistas reconocidos son Tony Smith, Robert Morris, Dan Flavin y Sol Le Witt. En todos sus trabajos encontramos una geometría que "no se presenta como metáfora o símbolo de otros contenidos, sino que pretende adquirir sentido exclusivamente por el valor intrínseco de sus formas y de sus materiales" (Historia del arte 1997: 2898.)

Sin embargo, es el pintor y escultor Ad Reinhardt (1913-1967) quien sintetizó la premisa fundamental de la creatividad minimalista: "Less is more."64 En sus escritos, Ad Reinhardt no deja dudas de su ruptura con el figurativismo: "Art is art-as-art and everything else is everything else. Art-as-art is nothing but art. Art is not what is not art. [...] Art is Art and Life is Life" (Reinhardt 1975: 53, 204.) Podemos pensar que Reinhardt llevó hasta sus últimas consecuencias esta propuesta, observando sus trabajos más avanzados. Éstos son cuadros rigurosamente monocromáticos, negros, unidimensionales.

\footnotetext{
${ }^{64}$ Reinhardt 1975: 205, tomada de Reinhardt 1957, “Twelve rules for a new academy”, originalmente publicado en la revista Art News (NY), de Mayo de 1957.
} 


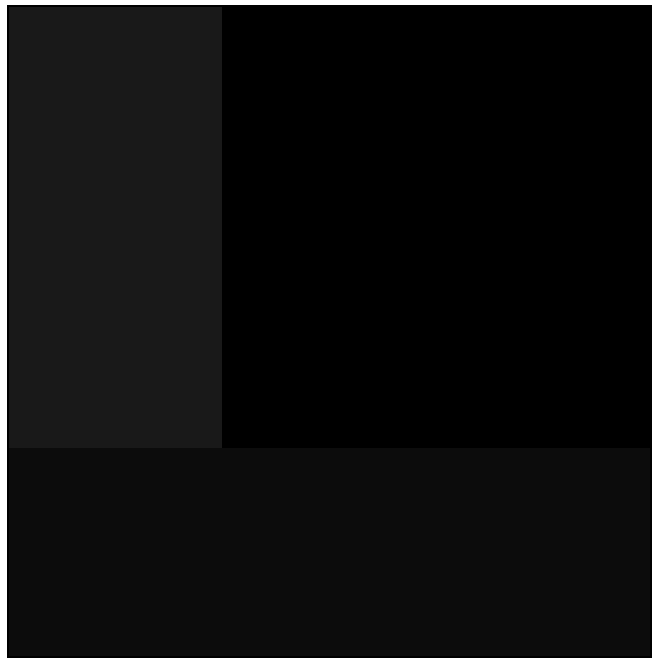

[La imagen es una reproducción propia del óleo Abstract Painting, de 1964, ilustrado en Reinhardt 1975: 41.]

A square (neutral, shapeless) canvas, five feet wide, five feet high, as high as a man, as wide as a man's outstretched arms (not large, not small, sizeless), trisected (no composition), one horizontal form negating one vertical form (formless, no top, no bottom, directionless), three (more or less) dark (lightless) no-contrasting (colorless) colors, brushwork brushed out to remove brushwork, a matte, flat, free-hand painted surface (glossless, textureless, non-linear, no hard edge, no soft edge) which does not reflect its surroundings -a pure, abstract, non-objective, timeless, spaceless, changeless, relationless, disinterested painting- an object that is self-conscious (no unconsciousness) ideal, transcendent, aware of no thing [sic., seguramente enfático] but art (absolutely no anti-art.) (Reinhardt 1975: 82, 83.)

Para Reinhardt, el arte es un universo con naturaleza propia, cuya comprensión requiere más que palabras. Quizá de ahí parten sus cuadros sin color.

These paintings and comments present no clear understanding, no precise ground plan for our labors to follow. They represent only bricks and mortal materials awaiting use in the shaping of our individual understanding. Until that time they remain but random comments. (Reinhardt 1975: 58.)

Este reto al entendimiento tuvo algunas consecuencias durante las exposiciones: "Two of the galleries and museum rooms had to be roped off because too many viewers were unable to resist touching the surface of the paintings and leaving their marks" (Reinhardt 1975: 84.) Al respecto, Barbara Rose explica que: "The resistance of the black paintings to interpretation, reproduction, and exhibition was part of their rigorous and demanding 
ethical stance. [...] The black paintings are icons without iconography." (Barbara Rose en Reinhardt 1975: 81, 82.)

Si el minimalismo contradice el principio de que "las artes son representaciones de la naturaleza y de la sociedad, representaciones que pueden ser reales o imaginarias, visibles o invisibles, objetivas o subjetivas” (Guiraud 1978: 90), entonces ¿qué tipo de representación hacen las pinturas negras de Reinhardt, cuando su intención es no representar?

Creatividades como el minimalismo y el arte conceptual llevaron los caminos de la plástica a su abstracción más pura, pero también los alejó del espectador, pues los signos se hicieron casi ilegibles y, por lo tanto, elitistas. El experimento de la autosuficiencia de la obra artística llevado a los extremos parece poner en riesgo, o al menos a discusión, el carácter envolvente del arte, es decir, la invitación al acto contemplativo (aistesis.) Se retomó el figurativismo, parecieron agotarse las vanguardias y, acaso entonces, entró en crisis la modernidad artística.

... the continuing vitality of abstraction was largely obscured at the end of the 1970s by the well-publicized explosion of figurative imagery. Following in the wake of the conscious anonymity of Minimal and Conceptual art, a number of major exhibitions at the turn of the decade unleashed evidence of a burning zest for personal expression and pictorical representation among many artists... The new figurative impulse, which sometimes went under the heading 'Neo-Expressionism', was interpreted as a timely response to the apparent dead-end of Modernism. With economic confidence shattered by the 1973 oil crisis, the notion of progress (which had underpinned modernity and hence modernists concepts of art) was increasingly called into question. In the context of the heart-searching that ensued, abstract art, like modernist architecture, came under attack. While recent modernist art had paradoxically been accepted by museums and institutions, it was also seen as elitist, lacking in popular appeal.

(Moszynska 1990: 225, 226.)

El minimalismo pasó de ser una propuesta artística de vanguardia -quizá la última del siglo XX- a ser un concepto corriente, funcionalista, convencional y conservador de la arquitectura, las artes decorativas, el vestido e incluso, ocasionalmente, de la misma publicidad que en principio combatió. Habrá sido entonces que el arte entró de lleno en lo que conocemos como posmodernidad.

El minimalismo, en fin, es una opción estético-estilística que reduce la expresividad de un lenguaje a sus elementos formales elementales o "estructuras primarias". 
Con este modelo, surgido de la plástica, de reducir la expresividad a las llamadas "estructuras primarias", apoyándose en las formas y los materiales, cada manifestación artística, creatividad o modo expresivo puede deducir su propia estilística, poética o estética minimalista. Así, si bien en nuestros días la plástica minimalista original es vista como un movimiento vanguardista aparentemente trascendido en la historia, sus valores estéticos perduran. Y no sólo perduran, sino que, efectivamente, se han extendido, o explicitado, en otras manifestaciones artísticas. En la literatura japonesa, por ejemplo, podemos considerar la sencillez de los haikús como un antecedente lírico importante. Otras propuestas literarias ya daban señales minimalistas. Según indican Deleuze y Guattari (1975), por ejemplo, Franz Kafka se manifestaba implícitamente Pour une littérature mineure. Hay que mencionar asimismo los destacados ejemplos de cuentistas norteamericanos como Raymond Carver (1976, ¿Quieres hacer el favor de callarte, por favor?), y latinoamericanos como Augusto Monterroso (El dinosaurio ${ }^{65}$ y algunos poetas mexicanos (desde los haikús de Octavio Paz hasta los poemínimos de Efraín Huerta.) Están también la música minimalista (como las óperas de Philip Glass) ${ }^{66}$ y el cine minimalista del Grupo Dogma. ${ }^{67}$ Hoy hay incluso tenis deportivos minimalistas para una pisada "más natural".

En el caso de Franz Kafka, lo que Deleuze y Guattari encontraron es una manera de vivir la literatura trascendiendo las fronteras de la lengua: la literatura menor.

Les trois caractères de la littérature mineure sont la déterritorialisation de la langue, le branchement de l'individuel sur l'immédiat-politique, l'agencement collectif d'énonciation. Autant dire que <<mineur>> ne qualifie plus certaines littératures, mais les conditions révolutionnaires de toute littérature au sein de celle qu'on appelle grande (ou établie.) (Delleuze y Guattari 1975, Kafka, pour une littérature mineure: 33. ) $^{68}$

\footnotetext{
${ }^{65}$ En realidad, el cuento más pequeño del mundo es de un mexicano: "En él se resumen no sólo mis dudas ante la vida y la muerte, sino la incertidumbre universal del hombre ante el destino. Este minicuento dice exclusivamente: “¿Y?”" (Óscar de la Borbolla, en Zavala 2000, Relatos vertiginosos: 24.)

${ }^{66}[\ldots]$ "minimal music emphasizes continual repetition of rhythm with slight alterations in pattern, and uses harmony sparsely" (Encarta 2000.) Hay que escuchar la ópera de Glass Einstein on the beach (Cocreada con el director teatral Robert Wilson y premiada en el Festival de Avignon de 1976.)

${ }^{67}$ El Grupo Dogma, fundado por el danés Lars von Trier, propone una cinematografía austera y anónima (sin crédito de autor, supuestamente), para cuyo fin sus realizadores juran un voto de castidad estética (ver hemerografías de Betancourt y Velásquez de León en Fuentes Consultadas.) Hay que ver las películas de esta escuela: Festen: La celebración (de Thomas Vinterberg), Los idiotas (de Lars von Trier), Secretos de familia: Mifune (de Krag Jacobsen) y Viva el rey (The king is alive, de Kristian Levring.)

${ }^{68}$ Confrontar con Steiner 1971, Extraterritorial.
} 
Como podemos ver, este modelo estético nos presenta una literatura menor que está, por contraste, mayúsculamente comprometida en lo político y lo social. Esta visión minimalista no nos habla, entonces, de una estética superficial. Tampoco es una estética de lo pequeño, si consideramos que disuelve la figura subjetiva del autor (singular, individual) en beneficio de la voz colectiva (plural, universal.) Deleuze y Guattari concluyen que el adjetivo "menor" no califica sólo ciertas literaturas, sino las condiciones que hacen revolucionaria a toda literatura en el seno de aquella que se presume "grande", recordándonos cómo Franz Kafka vino a representar una expresividad emergente y cómo esta expresividad se valió de una lengua ajena (el alemán, en el caso del escritor judío-checo-austro-húngaro) para realizar, finalmente, una revolución. Veamos ahora cómo esta revolución pudo alcanzar al teatro.

\section{La teatralidad menor de Sanchis}

$\mathrm{Si}$ las creatividades anteriores pudieron hallar el estilo que les permitiera alcanzar los márgenes de sus estructuras primarias, el teatro también. La cuestión era definir cuáles son las estructuras primarias del teatro. Parece ser un problema del signo teatral.

Entre todos los esfuerzos hechos al respecto (especialmente en torno a definir lo dramático), podemos citar el manifiesto "Por una teatralidad menor" (1994), que hiciera el dramaturgo y director valenciano José Sanchos Sinisterra, el cual parte esencialmente del modelo rizomático de Deleuze y Guattari, y del estudio que éstos hicieran sobre Kafka, aunque también se alimenta de propuestas como las de Jerzy Grotowski y Peter Brook (que mencionaremos más adelante.) El modelo de Sanchis es el primero que parece proponer teóricamente un minimalismo integral para todas las esferas del teatro, o sea: dramaturgia, puesta en escena, espacio escénico, actuación. Sus postulados son:

1. Concentración temática. Desde una teatralidad menor se optaría [...] por la concentración temática sobre aspectos parciales, discretos, incluso aparentemente insignificantes, de la existencia humana; o bien por el tratamiento de grandes referentes temáticos desde ángulos humildes, parciales, no pretendidamente totalizadores.

2. Contracción de la 'Fábula'. La acción dramática se ha liberado de su función relatora y nos ofrece un devenir escénico, un transcurrir situacional mediante el cual apenas se cuentan historias. 
3. Mutilación de los personajes. La teatralidad menor acepta la condición incompleta del personaje dramático, su carácter parcial y enigmático, revelador de apenas una mínima parte de sí mismo.

4. Condensación de la palabra dramática. La palabra no dice, sino que hace. No muestra, sino que oculta. No revela lo que el personaje parece decir, sino precisamente aquello que no quisiera decir.

5. Atenuación de lo explícito. Una teatralidad menor optaría por velar la discursividad obvia, evidente, acentuando la incertidumbre y la ambigüedad de los contenidos transmisibles, tanto en lo verbal como en lo no verbal. Daría así al receptor un papel más activo, induciéndole a "escribir" aquello que el espectáculo deja en penumbra, permitiéndole rellenar los huecos de la significación y reclamando, por tanto, su participación creadora.

6. Contención expresiva del actor. La teatralidad menor optaría por un estilo interpretativo contenido, austero, enigmático, por medio del cual -según la imagen del "iceberg"- lo manifiesto de su comportamiento escénico sería tan sólo una décima parte de lo que al personaje le ocurre, quedando sumergidas las otras nueve décimas partes.

7. Reducción del lugar teatral. Para que esta teatralidad menor funcione óptimamente $\mathrm{y}$ se produzcan los efectos participativos y cooperativos mencionados, hay que asumir determinadas limitaciones espaciales, hay que optar decididamente por unos ámbitos teatrales que reduzcan la distancia entre actor y espectador.

8. Descuantificación de la noción de público. Admitir como factor positivo, no como mal inevitable, la descuantificación del público, la aceptación del carácter minoritario -pero no elitista- del hecho teatral. [...] Más allá de un determinado número de espectadores, el individuo desaparece y se disuelve en lo masivo, perdiéndose con ello la dimensión de lo grupal o colectivo en que el encuentro teatral hunde sus raíces.

(Sanchis 1994: 27-31.)

¿Están en estos postulados los elementos o estructuras primarias de la teatralidad? Al respecto debemos señalar que mientras no se llegue todavía a un consenso sobre la especificidad de este lenguaje, poco tenemos, y todas las propuestas (incluida la arriba citada) son objeto de debate. Lo cierto es que Sanchis quizá sea el precursor hispanohablante de una manera explícitamente minimalista de acercarse al teatro, y plantea así su pertinencia:

... esta reducción o minorización de los parámetros de la teatralidad no implica, ni mucho menos, una tendencia hacia la simplificación del hecho escénico. Por el contrario, se hace más necesaria que nunca la exploración de la noción de complejidad, que los científicos enarbolan como nuevo paradigma de un pensamiento que pretenda comprender la realidad. (Sanchis 1994: 31.)

En este sentido, para comprender la realidad del teatro hay que asumir y explorar su complejidad, su naturaleza de signo múltiple, reconociendo primero que el teatro no 
solamente es el texto dramático. Por esto, también proponemos hablar acerca de la puesta en escena y de su ejecutante, el actor.

\section{Creatividad minimalista en la puesta en escena}

Actualmente, en los esfuerzos por desarrollar una semiología teatral, se dedican estudios no solamente a la literatura dramática, sino también al espectáculo. Uno de los problemas más discutidos del estudio del signo teatral es la complejidad del lenguaje escénico. Es este problema del lenguaje teatral el que ahora nos ocupa, si queremos llegar a identificar los elementos primarios de la teatralidad minimalista. Fernando de Toro (1987, Semiótica del teatro) plantea la problemática sobre la materia prima del fenómeno teatral de la siguiente manera:

Su complejidad esencial viene determinada por no tratarse, como otras prácticas artísticas, de un solo sistema significante, sino de una multiplicidad de sistemas significantes que a su vez operan doblemente: como práctica literaria y como práctica escénica.

Una pregunta surge de inmediato cuando pretendemos empezar una sistematización global del fenómeno teatral: ¿en qué se diferencia la práctica teatral de otras prácticas artísticas (espectaculares o literarias)? Responder a esta pregunta implica enfrentarse con el problema de la especificidad del discurso teatral como práctica significante.

(De Toro 1987: 12.)

Como podemos ver, aunque la naturaleza de la semiología teatral es tan complicada que tiende a dificultar su especificidad, lo que es evidente es que el fenómeno teatral no se cierra al exclusivo ámbito de la práctica literaria o literatura dramática. Al teatro lo constituye también la espectacularidad, la puesta en escena: "[...] el texto dramático y la puesta en escena": [...] "ambos fenómenos [...] constituyen la esencia misma del objetoteatro" (De Toro 1987: 13.) Una de las discusiones acerca de esta problemática está directamente relacionada con los aspectos de la actoralidad y la recepción en el fenómeno teatral, es decir, más con la relación actor-espectador que con la dramaturgia, y son aspectos que podrían analizarse a partir de una perspectiva minimalista.

Si buscamos en el teatro como espectáculo, descubriremos que las alternativas más renovadoras en el pasado próximo (de los años 1960 hacia el presente) se declaran abiertamente por algún modelo de minimalismo. Jerzy Grotowski y Peter Brook son quienes proponen un "teatro pobre” (1968) y un "espacio vacío" (1968), respectivamente, 
en donde el actor es el elemento primario, la estructura más simple y esencial del arte teatral.

El manifiesto de Grotowski es claro: "Eliminando gradualmente lo que se demostraba como superfluo, encontramos que el teatro puede existir sin maquillaje, sin vestuarios especiales, sin escenografía, sin un espacio separado para la representación (escenario), sin iluminación, sin efectos de sonido, etc. [Pero] No puede existir sin la relación actor-espectador" (Grotowski 1968: 13.) Por su parte, la concepción de Brook armoniza con la anterior: "Puedo tomar cualquier espacio vacío y llamarlo un escenario desnudo. Un hombre camina por este espacio vacío mientras otro le observa, y esto es todo lo que se necesita para realizar un acto teatral" (Brook 1968: 9.) Ambas concepciones, la de Grotowski y la de Brook, claramente proponen una espectacularidad minimalista apoyada en el trabajo actoral.

El tiempo ha confirmado el valor fundamental de estas ideas. Brook mismo, de visita en Soweto, Sudáfrica, cuando todavía en ese lugar no había teatros, foros, auditorios, se sorprendió al verificar cómo su libro (El espacio vacío) había sido utilizado para crear un movimiento teatral.

Antes de leer el libro estaban convencidos de que hacer teatro en sus condiciones los abocaría al desastre sin remedio, porque en los municipios negros de Sudáfrica no había un solo "edificio de teatro". Creían que no podrían llegar muy lejos si no disponían de teatros de un millar de asientos, con telones y telares, luces y focos de colores, como en París, Londres y Nueva York. Y de repente descubrieron un libro cuya primera frase afirmaba que tenían todo lo que necesitaban para hacer teatro. (Brook 1994 [1993.] 13.)

Pero el panorama posibilita no sólo un modelo de montaje. También se abre la posibilidad para dirigirlo hacia un novedoso modelo de análisis teórico que habría que desarrollar

cuidadosamente y que, tentativamente, plantearía preguntas como las siguientes: ¿Hasta dónde el fenómeno escénico puede ser reductible? ¿Puede el minimalismo ser para el teatro un paradigma alternativo que integre la investigación con la creación?

\section{El actor transiluminado de Grotowski}

El último cambio radical en la definición del actor lo planteó Jerzy Grotowski: "El verdadero alumno traiciona al maestro con 'grandeza'" (en Jiménez 1990: 503.) En una 
antología sobre Constantin Stanislavski y sus epígonos, Sergio Jiménez (1990. El evangelio de Stanislavski según sus apóstoles, los apócrifos, la reforma, los falsos profetas y Judas Iscariote. México: Gaceta) sugiere que el actor y director ruso fue el mesías del mundo del teatro, y nos ofrece selectos textos de la "buena nueva", el sistema de actuación vivencial, tomando en cuenta a sus discípulos, entre quienes hubo seguidores fieles, evangelistas apócrifos, reformistas, falsos visionarios y, desde luego, un gran traidor. El Judas de este Evangelio teatrológico es, para Jiménez, el director polaco Jerzy Grotowski, fundador del Teatr Laboratorium.

Cuando inicié mis estudios en la Escuela de Arte Dramático, en la Facultad para actores, fundé la base entera de mi saber teatral sobre los principios de Stanislavski. Como actor estuve poseído por Stanislavski. Era un fanático. Pensaba que él era la llave que me abriría todas las fuerzas de la creatividad. Quería comprenderlo mejor que los otros. Trabajaba mucho para llegar a saber lo más posible sobre aquello que había dicho o que otros habían comentado sobre él. Esto me llevó, según las reglas del sicoanálisis, del periodo de imitación al periodo de rebelión. (Jerzy Grotowski. "Respuesta a Stanislavski", en Jiménez 1990. 490.)

El sentido de esta rebelión era, desde luego, hallar un camino propio.

Con toda su vida en el arte, Stanislavski dio el ejemplo de que es necesario estar preparados para el trabajo; precisamente él formuló la necesidad del trabajo de laboratorio y de los ensayos en cuanto a procesos creativos sin espectadores. También la obligación del entrenamiento para el actor rindió grandes servicios. (Grotowski en Jiménez 1990. 494.)

A partir de este aprendizaje significativo, Grotowski inició un trabajo de búsqueda que requirió de la experimentación constante, hallando muchos elementos relacionados con la corporalidad del actor: procesos orgánicos, éxtasis o trance, confesión, sinceridad corporal, sistema de signos preciso, aniquilamiento de bloqueos o resistencias, vía negativa y entrenamiento.

Todos los ejercicios mantenidos por nosotros eran dirigidos sin excepción al aniquilamiento de las resistencias, de los bloqueos, de los estereotipos individuales y profesionales. Se trata de ejercicios-obstáculo. Para superar los ejercicios, que eran como una trampa, era necesario descubrir el propio bloqueo. En el fondo todos estos ejercicios tenían un carácter negativo, servían para descubrir qué cosa no se debía hacer. Pero jamás: qué cosa y cómo hacerla. Y siempre en relación con nuestro propio camino. Si los ejercicios eran ejecutados con excesivo dominio, se cambiaban o bien se abandonaban. Si se continuaba con ellos, comenzaba la técnica por la técnica, el saber cómo. Cuando sentíamos que las fuentes no 
funcionaban en nosotros (o sobre nosotros), que las resistencias se bloqueaban, se cerraban, que "el proceso creativo procedía", y todo era estéril, entonces volvíamos a los ejercicios. Y encontrábamos las causas. No las soluciones, sino las causas. (Grotowski en Jiménez 1990. 495.)

El producto escénico de este sendero es muy revelador.

En primer lugar tratamos de evitar todo eclecticismo, intentamos rechazar la concepción de que el teatro es un complejo de disciplinas. Tratamos de definir qué es el teatro en sí mismo, lo que lo separa de otras categorías de representación o de espectáculo. En segundo lugar, nuestras producciones son investigaciones minuciosas de la relación que se establece entre el actor y el público. En suma, consideramos que el aspecto medular del arte teatral es la técnica escénica y personal del actor. (Grotowski, Hacia un teatro pobre, 9.)

La búsqueda por la especificidad del teatro lleva al Teatr Laboratorium al despojo de los elementos superfluos del escenario, a un empobrecimiento que potencie e inspire la presencia comunicativa del actor frente al espectador. De ahí la importancia de la exploración de la comunión teatral y del entrenamiento vocal, físico, mental y espiritual del actor.

Todo se concentra en un esfuerzo por lograr la "madurez" del actor que se expresa a través de una tensión elevada al extremo, de una desnudez total, de una exposición absoluta de su intimidad: y todo esto sin que se manifieste el menor asomo de egoísmo o autorregodeo. El actor se entrega totalmente; es una técnica del "trance" y de la integración de todas las potencialidades psíquicas y corporales del actor, que emergen de las capas más íntimas de su ser y de su instinto, y que surgen en una especie de "transiluminación". Educar a un actor en nuestro teatro no significa enseñarle algo; tratamos de eliminar la resistencia que su organismo opone a los procesos psíquicos. El resultado es una liberación que se produce en el paso del impulso interior a la reacción externa, de tal modo que el impulso se convierte en reacción externa. El impulso y la acción son concurrentes: el cuerpo se desvanece, se quema, y el espectador sólo contempla una serie de impulsos visibles. (Grotowski, Hacia un teatro pobre, 10 y 11.)

Resulta pertinente estudiar estas cuestiones desde una escenificación contemporánea de la obra de Calderón, misma que en esta tesis estudiaremos como referencia para nuestra propia indagación representacional: la puesta en escena de Grotowski de El príncipe constante. 


\title{
El príncipe constante según Jerzy Grotowski
}

En la ultramodernidad del siglo XX el director polaco Jerzy Grotowski redescubre esta orientación de los alcances del actor y hace de El príncipe constante (adaptada por el escritor romántico Julius Slowacki) su puesta en escena más emblemática.

El director no pretende, sin embargo, representar El príncipe constante tal como es. Pretende imprimirle su propia visión a la obra y la relación de ese escenario con el texto original es la relación que existe entre una variación y el tema musical original. (Ludwik Flaszen, capítulo "El príncipe constante", en Grotowksi. Hacia un teatro pobre. 75. )

En este montaje las paradojas del barroco son interpretadas como un despojamiento extremo de los ornamentos materiales de la representación teatral, a cambio de un rebuscamiento obsesivo de la perfección interpretativa.

\begin{abstract}
Abandonamos el maquillaje, las narices postizas, los estómagos abultados falsamente, todo aquello que el actor utiliza en su vestidor antes de su representación. Advertimos que era un acto de maestría para el actor cambiar de tipo, de carácter, de silueta (mientras el público contempla) de una manera pobre, usando sólo su cuerpo y su oficio. La composición de expresión facial fija, utilizando los músculos del actor y sus propios impulsos, logra el efecto de una transubstanciación terriblemente teatral, mientras que el maquillaje del artista es sólo un artificio. (Grotowski. Hacia un teatro pobre. 15.)
\end{abstract}

Esto significa que no se encuentran retablos dorados en la escenografía, sino en la maestría -el virtuosismo- con la que el actor proyecta su energía y todas sus capacidades orales, corporales y aun espirituales, puestas todas al servicio de la misma relación actorespectador en el teatro que buscaran Bernini, Rubens y Rembrandt en la escultura y la pintura (una relación mística).

El productor cree que, aunque no fue fiel a la letra, al texto de Calderón, retiene sin embargo el significado más íntimo de la obra [la intentio del autor]. La representación es la trasposición de las antinomias profundas y de los rasgos más característicos de la era barroca, su aspecto visionario, su música y su apreciación de lo concreto y su espiritualismo. (Ludwik Flaszen, capítulo "El príncipe constante", en Grotowksi. Hacia un teatro pobre. 77.$)$

Con base en lo anteriormente comentado, no es arriesgado calificar esta puesta en escena como un ejercicio Neobarroco. 
En la escena de apertura, el Primer Prisionero colabora con sus perseguidores. Yace en una cama ritual y es simbólicamente castrado y después de ser vestido con un uniforme se convierte "en uno de la compañía". La representación es un estudio del fenómeno de "inflexibilidad" que no consiste en la manifestación de fuerza, dignidad y valor. A la gente que lo rodea y que lo mira como si fuera más bien un extraño animal, el Segundo Prisionero -el Príncipe- opone sólo pasividad y gentileza, pertenece a un orden de valores más espirituales. Parece ofrecer una oposición a los hechos villanos y feos de la gente que lo rodea y ni siquiera discute con ellos. Están más allá de su consideración. Rehúsa ser uno de ellos. De esta manera los enemigos del Príncipe, que aparentemente lo tienen en su poder, en realidad no tienen influencia sobre él. Mientras se somete a sus malas acciones, conserva su pureza hasta caer en el éxtasis. (Ludwik Flaszen, capítulo "El príncipe constante", en Grotowksi. Hacia un teatro pobre. 75 y 76.)

Con respecto al espacio, el minimalismo de Grotowski mostró cómo entre más sencilla fuera la propuesta escenográfica, más implicaciones simbólicas podía sugerir.

El arreglo del escenario y del auditorio se parece en cierta medida a algo que está entre una plaza de toros y una mesa de operaciones. Se puede comparar con los que contemplan desde arriba algún deporte cruel en una antigua arena romana o una operación quirúrgica tal y como la retrató Rembrandt en su Anatomía del doctor Tulp. (Ludwik Flaszen, capítulo "El príncipe constante", en Grotowksi. Hacia un teatro pobre. 76.)

Los atuendos igualmente eran parcos, sencillos y, por lo mismo, con una significación contundente.

El pueblo que rodea al Príncipe, una sociedad alienada y particular, usa togas, pantalones y botas altas para mostrar que goza detentando el poder, confía en su juicio, particularmente cuando se refiere a gente de otra categoría. El Príncipe lleva una camisa blanca -un símbolo ingenuo de su pureza- y un saco rojo que a menudo puede convertirse en un sudario. Al final de la obra está desnudo, y nada lo defiende, sólo su identidad humana. (Ludwik Flaszen, capítulo "El príncipe constante", en Grotowksi. Hacia un teatro pobre. 76. ) 


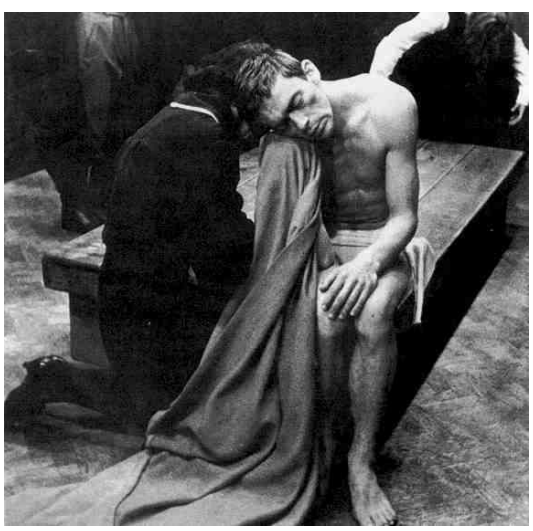

(Rizsard Cieslak es Don Fernando en El príncipe constante, dirigida por J. Grotowski.)

Los sentimientos de la sociedad hacia el Príncipe no son uniformemente hostiles, más bien son la expresión de un sentimiento de indiferencia y extrañeza, combinado con una especie de fascinación, y esta combinación contiene en sí misma la posibilidad de respuestas tan extremas como la violencia y la adoración. Todos desean poseer al mártir y al final de la representación luchan por él como si fuese un objeto precioso, en tanto que el héroe se enfrenta constantemente a contradicciones sin fin y se somete a la voluntad de sus enemigos. Una vez que el hecho se consuma, el pueblo que atormentó al Príncipe hasta matarlo lamenta sus acciones y se compadece de su suerte. Las aves de rapiña se convierten en palomas. (Ludwik Flaszen, capítulo "El príncipe constante", en Grotowksi. Hacia un teatro pobre. 76.$)$

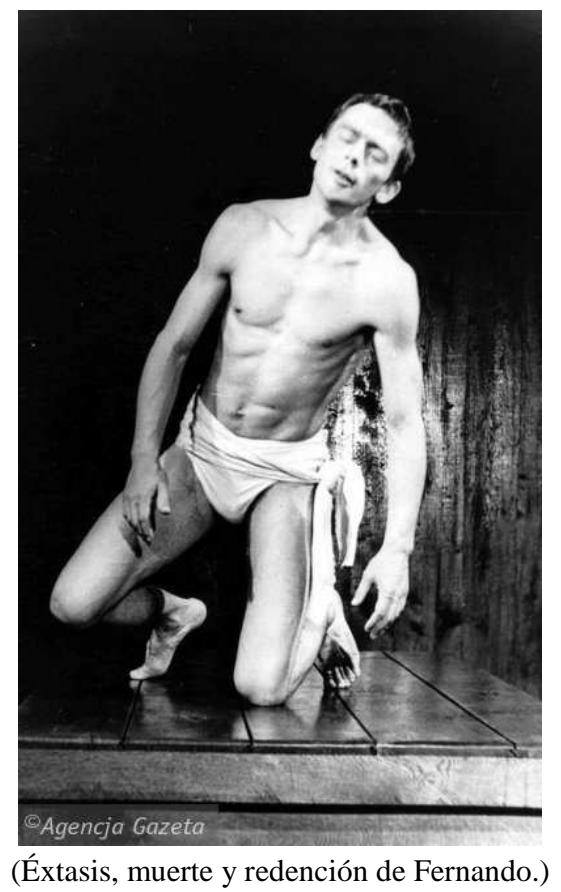

Al final el Príncipe se transforma e un himno vivo en homenaje de la existencia humana, a pesar de haber sido perseguido y humillado estúpidamente. El éxtasis del Príncipe es su 
sufrimiento, sólo tolerable si se ofrece a la verdad como en un acto de amor. Paradójicamente, la representación es un intento por sobrepasar en sí misma la pose trágica. Trata de quitar todos los elementos que puedan forzarnos a aceptar este destino trágico. (Ludwik Flaszen, capítulo "El príncipe constante", en Grotowksi. Hacia un teatro pobre. 76 y 77.)

Mucho de este logro se debió al particular entrenamiento que ya hemos venido describiendo, mismo que es base de una definición concreta de la actuación como investigación.

\section{La creación como investigación}

Grotowski desarrolló sus experimentos desde los años 60 y hasta los 80, justo antes de morir. Acerca del training y sus resultados en uno de los últimos periodos del Laboratorium, Ryszard Cieslak, el actor más representativo del "Método Grotowski", explica:

Tengo a mis espaldas el entrenamiento de las actividades parateatrales, aquel periodo de trabajo antes con Grotowski y luego por mi cuenta, en que no había "espectadores", sino solamente personas copartícipes. Por dos días trabajábamos sin intervalos, sin dormir. Hacíamos una suerte de recorrido común, con uno o más leaders. Aparte de esto, cuando se está presente en escena, cuando se crea, hay una particular tensión que permite olvidar que uno está cansado. Una suerte de trance, un particular estado de conciencia que dispone al actor a otro nivel de energía. Cuando el espectáculo termina, entonces sí que uno está cansado, agotado. Pero no durante el espectáculo. Entonces no hay tiempo para el cansancio. (Ryszard Cieslak, en entrevista con Marzena Torzenka. "La última entrevista con Ryszard Cieslak”, en Máscara. Año 4, Número 16. Enero de 1994. 26.)

Esta formación parece generar una actitud no sólo creativa, sino también de constante aprendizaje: la del actor-investigador.

Tengo la impresión, más bien estoy seguro que en especial, en la formación del actor nada está terminado. El actor nunca puede decir que ha terminado el periodo del aprendizaje. Una vez durante el periodo en que iba a la escuela, leí en una antología de poesía americana una de Crane que expresaba bien la idea de esta búsqueda mía. Es una poesía sobre un hombre que corre hacia el horizonte para tocarlo, creyendo que podrá tocarlo sólidamente con las manos. Así sucede con nuestra profesión. Corremos hacia el horizonte queriendo al final tocarlo. Pero en realidad la lejanía siempre es la misma. No se puede tocar. Tal vez por esto es tan fascinante. (Cieslak en Torzenka 1994. 27.) 
Es el perfil profesional de Cieslak el que nos da un bosquejo de lo que un nuevo enfoque teatrológico nos permitirá alcanzar: un aprendizaje vivencial de la literatura, así como del arte teatral y de la actoralidad.

Hasta aquí sólo hemos querido ofrecer una noción sobre la creatividad minimalista y acerca de cómo ésta ha estimulado algunos rumbos de la investigación en humanidades, del estudio vivencial de la literatura dramática y del arte teatral. Parece suficientemente claro cómo esta opción estética puede facilitar una aproximación significativa del Teatro Áureo al receptor contemporáneo en condiciones económico-materiales muy limitadas: Falta de dinero, de espacio, de tiempo, de intérpretes, de recursos materiales escenográficos y técnicos (luz, sonido, efectos especiales), de vestuario, de maquillaje.

Recordemos que son funciones de la filología: estudiar una cultura tal y como se manifiesta en su lengua y especialmente en su literatura, además de reconstruir, fijar e interpretar el texto (Vid. DRAE: "filología”.) No intentamos hacer otra cosa con El príncipe constante. En este sentido, en el siguiente capítulo plantearemos cómo hacer una interpretación teatral de El príncipe constante, de Calderón, apoyándonos para esa tarea en la austeridad y la discreción de una modalidad representacional minimalista proveniente del Barroco original: el bululú. Para ello dispusimos cuidadosamente los estudios preliminares (historia, semiología, genealogía, estética barroca y neobarroca), así como un análisis lingüístico contextual de los versos de Calderón (lengua, literatura); con los cuales reconstruimos una textualidad en principio inestable (con variaciones entre los originales de 1629 y 1636), misma que fijamos en una versión coherente, adecuada (se respeta sentido e intentio original con una forma más legible) y crítica (se agregan apuntes, notas y escenas especiales tanto para académicos como para gente de teatro). 


\title{
CAPÍtulo VI
}

\section{EL PRÍNCIPE CONSTANTE}

"La tragedia perdida del Infante Santo Fernando de Portugal”, de Don Pedro Calderón de la Barca, tal y como habría sido interpretada en bululú por Don Antonio García de Prado

en la ermita de Sant Jordi, una legua al norte de Barcelona, la madrugada del 23 de abril de 1629, como penitencia para ingresar a

\section{la Cofradía de Actores de Nuestra Señora de la Novena de Madrid}

\author{
Adaptación de
}

La comedia famosa del príncipe constante de Pedro Calderón de la Barca, concepción minimalista para una puesta en escena neobarroca y notas por

\author{
JORGE PRADO ZAVALA
}

\footnotetext{
"De cómo el infante don Fernando, príncipe de Portugal y maestre de la orden católica de caballería de Avis, intentó arrebatar el puerto de Tánger a los moros, pero cayendo preso -y al no aceptar su rescate con la entrega de la estratégica ciudad de Ceuta- es maltratado hasta morir, defendiendo con su vida la fe cristiana."

O bien,

"De la representación teatral de una aventura del siglo XV por un actor del siglo XVII a principios del siglo XXI." 


\section{Concepción Minimalista para una puesta en escena Neobarroca}

Si partimos del principio de que al escribir drama -allende los propósitos ideológicos (políticos, morales, religiosos, etc.)- una intentio fundamental del dramaturgo es que su obra sea representada $^{69}$, entonces es pertinente reconocer que en este género el escritor crea obras inacabadas de natura y que es esencial a todo drama, para ser una obra completa, su representación. Mientras la representación no suceda, el texto dramático permanecerá como una obra inconclusa o, para ser más precisos: en construcción. ${ }^{70}$ Por su parte, es tarea del actor el ejecutar el tránsito del papel al escenario al aportar los detalles definitivos de esa construcción, los específicos para el espacio-tiempo de la escena efímera. Se infiere que la lectura del actor, en consecuencia, está al servicio de la intentio más elemental del dramaturgo.

En haziendo el poeta el poema actiuo, luego lo entrega a los actores para que hagan su oficio; de manera que, como muerto el enfermo, espira el officio del medico y empieça el del clérigo, hecho el poema actiuo, espira el oficio del poeta y comiença el del actor, el qual está dividido en las dos partes dichas, en el ornato o en el gesto y ademán; y, si no lo entendéys agora, escuchad: ornato se dize de la compostura del teatro y de la persona, y ademán aquel movimiento que haze el actor con el cuerpo, pies, braços, ojos y boca cuando habla, y aun quando calla algunas vezes. (Alfonso López Pinciano. Philosophia antigua poética. 534 y 535 [521 y 522].)

Una alternativa que nos permita concebir una producción de El príncipe constante con nuestros limitados recursos económicos y materiales será, por definición, minimalista (con austeridad y discreción). El montaje que realizó con este estilo Jerzy Grotowski demostró ya (en los años 60 y 70 del siglo XX) que aun en esa austeridad se puede ser fiel al contexto original de la obra, tanto así que ese espectáculo fue calificado como Neobarroco (vid capítulo V de esta tesis). Aquí defenderemos cómo es que se puede ser leal tanto a la intentio como al contexto original de producción al recuperar las posibilidades minimalistas de la modalidad espectacular barroca más humilde de todas: el bululú.

Para ello no olvidemos el contexto cultural de producción en el que fue escrita, puesta en escena y editada por primera vez la obra en el siglo XVII, lo cual planteamos en el capítulo I de esta tesis (apoyándonos en Oehrlein, Díez Borque, Sirera, etc.) Ahí

\footnotetext{
${ }^{69}$ No se escribe drama, no se es dramaturgo, si no se desea escribir para la escena.

${ }^{70}$ Diríamos también como work in progress: un trabajo en progreso, una obra en proceso de realización.
} 
explicamos cómo los actores y el mismo Calderón debían flexibilizar su respeto por el poema dramático para adecuarlo a las condiciones objetivas de representación. Recordemos también que el análisis semiológico (Greimas, Ubersfeld, Román Calvo et al) desarrollado en el capítulo II arrojó como claro protagonista al infante Fernando. Su trayectoria es el eje de la acción, por lo cual las demás líneas argumentales son accesorias, complementarias. Su diégesis fundamenta los propósitos estéticos del autor, tales como: asombrar, conmover y hacer reflexionar con una aventura emocionante; promover los valores de la fe católica (principalmente la constancia y el estoicismo, entre muchos otros), y ensalzar a un mártir histórico, nacionalista y religioso. Todo el accionar de Fernando se orienta a defender la fe católica y llevarla a la victoria sobre el enemigo infiel. Con base en ese análisis, en el capítulo III justificamos la pertinencia de una lectura trágica. Concentrar nuestro estudio en la trayectoria del personaje trágico protagonista subraya todas las intenciones dramatúrgicas (empezando por clarificar el elemental de la representación), pero por encima de todas el espíritu moral de la obra, su dimensión mística. Puesto que el misticismo es característica básica de El príncipe constante, procedimos en el capítulo IV a analizar el modo estético de ver y entender el mundo durante el Barroco, ${ }^{71}$ encontrando que toda la ornamentación y el rebuscamiento que le son propios no son otra cosa sino la manifestación de una aspiración metafísica, trascendental, por lo que se habla de éxtasis, transubstanciación y santidad. Tal aspiración es más esencial que los decorados físicos, visibles o palpables, y coincide con la alternativa estética estudiada en el capítulo $\mathrm{V}$ denominada minimalismo, correspondiente ya al siglo XX. Vimos que la indagación minimalista por la esencia del arte coincide de muchas maneras con la búsqueda del Barroco por la esencia espiritual del hombre. La austeridad y la discreción del minimalismo despojan al discurso estético de todo cuanto le es superficial y accesorio, sea en la pintura, la literatura o el teatro, para encontrar sus componentes elementales: línea, color, forma en las artes visuales; personaje y situación en la literatura; la relación actor-espectador en el caso del teatro. Se trata de descuantificar los valores materiales de la obra artística $^{72}$ para potenciar sus cualidades más esenciales y, por lo tanto, legítimas ("Less is more", dice Ad

\footnotetext{
${ }^{71}$ Las artes plásticas y el teatro se aprecian primero por la vista antes que por cualquier otro sentido.

${ }^{72}$ En el caso del teatro esta reducción o minorización abarca al edificio teatral, al texto dramático, al público, al elenco y a todo ámbito en donde debiera procurarse más calidad que cantidad.
} 
Reinhardt, exponente del minimal art). Nuestra investigación intenta ahora legitimar una lectura escénica vía la interpretación cuidadosa de esas cualidades esenciales.

Imaginemos la España de 1629. El joven Pedro Calderón está por terminar el que hasta ahora ha sido su trabajo más exhaustivo. Querrá ser mejor que "el mejor", es decir, que Don Félix Lope de Vega, y por ello su ejercicio consistiría en mejorar la Comedia famosa de la fortuna adversa del Infante don Fernando de Portugal (atribuida al Fénix de los Ingenios) con una versión propia. Dado que parece bastante complicado desarrollar una comedia (drama jocoso de final feliz) acerca de una fortuna adversa (aunque dio en llamarse "comedias" a casi toda la dramaturgia a partir del Arte nиеvo), es probable que un tratamiento preliminar tomara la forma de tragedia convencional. También es posible que ese manuscrito, quizá a punto de ser desechado por Calderón, fuera aprovechado en calidad de "puesta a prueba" por un actor. Posteriormente, por supuesto, tal documento (seguramente lleno de ajustes y notas de aquel actor) habría permanecido "extraviado" por las arenas del tiempo hasta su rescate por algún diletante.

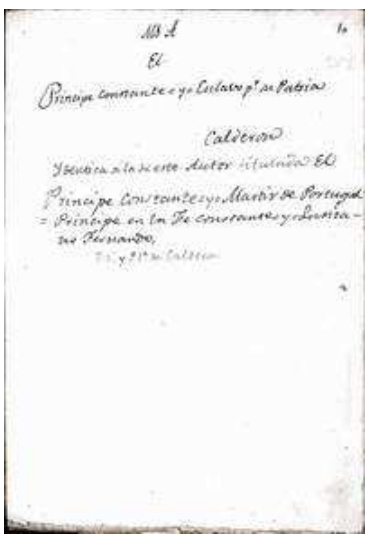

(Manuscrito original de El príncipe constante por Calderón [Biblioteca Nacional de España].)

La Comedia Famosa del Príncipe Constante es reconocida como la primera obra maestra de Calderón y fue escrita alrededor de 1629 en un contexto de producción marcado por el Arte nuevo de hacer comedias de Félix Lope de Vega. El éxito final de la obra ganó para su autor el ser dramaturgo de planta de la casa real. Mucha de la crítica moderna encuentra una tragedia en su lectura, mientras otros académicos refrendan con ella la amplia tesitura que tuvo el movimiento estético de la comedia nueva. Para esta adaptación ofrecemos la solución ficcional de un manuscrito apócrifo: una tragedia "perdida" precursora de la 
comedia "famosa". Así, aunque de acuerdo con la propia poética lopista El príncipe constante puede leerse como una tragedia por tratar las acciones "reales y altas", predominantemente históricas según Lope, y no únicamente como una comedia que trataría de las "acciones humildes y plebeyas", básicamente de "fingimiento" (una comedia con final triste), nada contradice la eventual existencia del borrador preliminar ${ }^{73}$ de Calderón fundado en la anécdota del trágico destino del infante Fernando en las guerras de Reconquista, antes de desarrollar la trama amorosa paralela de Fénix y Muley, así como los detalles propiamente cómicos de Brito, ni la posibilidad de que ese documento llegara a las manos de un actor como reto representacional.

Ocasionalmente los autores mismos han intervenido en sus propios textos y producido versiones adaptadas a las diferentes condiciones de recepción en dos lugares de representación. (Josef Oehrlein, El actor en el teatro español del Siglo de Oro. 156.)

De cualquier manera y ante las constantes acciones de censura en contra de las representaciones teatrales, ¿cuántos borradores no habrá escrito Calderón y entregado a los autores de comedias para ser representados, pero además mutilados y pirateados, antes de la edición princeps que no verá la luz sino hasta 1636 (recuerda Evangelina Rodríguez Cuadros en Un discreto a voces), impresa por José Calderón, hermano del poeta?

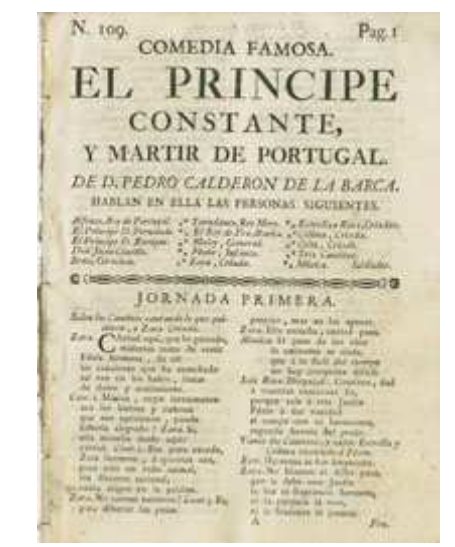

(Biblioteca Nacional de España.)

\footnotetext{
${ }^{73}$ Hoy llamaríamos a un documento análogo: borrador, documento de trabajo, obra en proceso, work in progress, obra negra, versión preliminar, texto pre-espectacular, premisa o proyecto dramatúrgico, etc. Bajo esta calidad no definitiva son justificables las diferencias que hagan falta con las ediciones oficiales.
} 
El ejercicio de proponer un apócrifo no es ajeno, por cierto, a las técnicas contemporáneas de investigación humanística. Uno de los ejemplos más notables al respecto es el desarrollado por Umberto Eco en El nombre de la rosa, novela donde el semiólogo analiza las crisis de evolución del pensamiento humano, junto con los extremos -incluso criminales- que tales crisis conllevan, tomando como cronotopo imaginario la biblioteca de un convento medieval (donde varios asesinatos denotan la represión hacia el conocimiento de un "extraviado" texto de Aristóteles). Otro caso de interés es Un discreto a voces: Entrevista (imaginada) con Don Pedro Calderón de la Barca, de Evangelina Rodríguez Cuadros (el título se explica por sí mismo). El apócrifo consciente es pues una forma que se vale de la ficción para expresar lo que con la mera teoría no se alcanzaría. Una denominación técnica es la siguiente:

Intertextualidad posmoderna. Relación de integración de elementos de un grupo de textos, es decir, de sus rasgos genológicos y su contexto cultural. Recuperación del pasado (y de sus diversas interpretaciones y valoraciones) en la síntesis de un presente donde el texto habla de sí mismo y de sus condiciones de posibilidad. Creación de pseudocitas, mistificaciones, facsímiles apócrifos y otros recursos donde se imitan rasgos formales y estilísticos. Relación sintagmática (de combinación) de rasgos textuales (de textos existentes y apócrifos). Adición de un nuevo texto a significados ya existentes. Afirmación de lo viejo y su eternidad. (El lector puede encontrar el sentido al texto desde su perspectiva personal). (Pavlicic citado en Lauro Zavala. La precisión de la incertidumbre. 142.)

En donde particularmente un facsímil apócrifo consiste en la "reproducción física de un original inexistente" (Pavlicic citado en Zavala. La precisión de la incertidumbre. 139), como nuestra Tragedia perdida de El príncipe constante.

Por otro lado, recordemos al verdadero Don Antonio García de Prado (n. 1594 ó 95, m. 1651, indica Oehrlein), mejor conocido como Antonio de Prado, "autor de comedias" (o sea actor y empresario) "de los nombrados por S. M.” (así se llamaba a los autorizados por el rey y el Consejo Real para representar), es decir, reconocido oficialmente por Felipe IV (rey de España de 1621 a 1665), y que ejerció sus oficios con mucho éxito durante el siglo XVII, principalmente en Madrid, donde residía, aunque se sabe (por contratos conservados) que llevó a cabo varias giras por la provincia española (como reseña José Antonio Mateos Carretero en "El teatro en Parla en el siglo XVII”). 


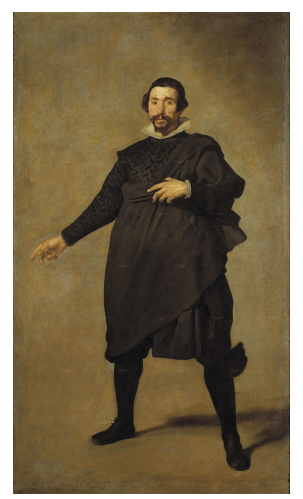

(Retrato del actor Pablo de Valladolid por Velásquez [1635. Museo del Prado, Madrid], coetáneo de Antonio de Prado.)

Erasmo Hernández sintetiza una descripción de nuestro actor-empresario Antonio de Prado como: "autor de comedias, que entre 1626 y 1630 estaba en pleno trabajo, según noticias recogidas por Bergman [1965, 526-528]" (Erasmo Hernández González. "Estudio de La despreciada querida de Juan Bautista Villegas"). Josef Oehrlein detalla cómo su hijo Sebastián de Prado también fue un intérprete reconocido y cómo la familia De Prado, en general, se vio muy asociada al medio teatral en todo el siglo XVII (Oehrlein. El actor en el teatro español del Siglo de Oro), sobresaliendo como agentes destacados en el proceso de profesionalización del estamento social del actor, con huellas documentadas hasta inicios del siglo XIX (con una Antonia de Prado casada con el actor Isidoro Maíquez, señala Oehrlein, e incluso quién sabe si hasta el llamado Cine de Oro mexicano del XX con la conocida actriz María Prado). Antes de abrir su capítulo teatral, la Casa de Prado había sido considerada históricamente como una casta de descendientes de reyes al servicio de distintos monarcas.

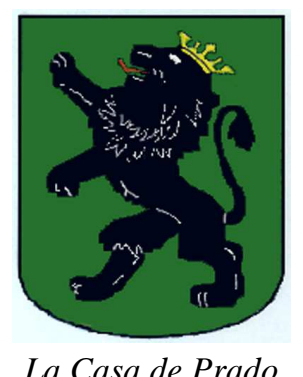

Se trata de un apellido castellano, concretamente leonés, siendo considerado don Nuño Fruela, hijo del rey don Fruela II y nieto del rey don Alfonso III, como tronco de este muy cualificado linaje. A este respecto existe cierta versión que reproducimos, tomándola de la obra "Reinos y Señoríos de España", del acreditado genealogista don Francisco Piferrer. La transcripción es esta: "Acerca del origen del apellido Prado se lee que estando de caza el rey de León, don Ramiro III, encontró en un ameno prado a una hermosa doncella, de quien tuvo un hijo y en memoria del encuentro se le dio el apellido Prado". Este dictamen nos parece pueril y además inverosímil. El marqués de Mondéjar escribe que estando en Braga un rey de León, se prendó de doña Blanca Gutiérrez de Silva, Señora de la Villa del Prado, de quien tuvo hijos que tomaron por apellido el nombre del 


\begin{abstract}
señorío de su madre, y por armas las de la casa de Silva, mudando los esmaltes; añadiendo que adoptaron el león negro para recordar que las visitas del rey fueron con frecuencia protegidas por la oscuridad de la noche. En apoyo de este dictamen dice el citado marqués que, en el año 1510, con unas fuertes avenidas que tuvo el río, se desmoronó parte del puente de la villa del Prado y que en una de sus piedras se descubrió esta inscripción: "Blanca et blance et rex legionis fecerunt". Al anteriormente citado tratadista Piferrer tampoco le parece muy fundada esta opinión y dice que sin ánimo de poner en tela de juicio la veracidad de la citada inscripción no ve ninguna dependencia de causa y efecto entre su autoría y las relaciones del rey con doña Blanca Gutiérrez de Silva. Prescindiendo pues, de aventuradas suposiciones, la realidad histórica señala que don Nuño Fruela tuvo descendientes entre los cuales se destacaron varios muy eminentes. El primero de ellos, legítimos por varonía, fue don Martín Díaz de Prado, que floreció a principios del siglo X y prestó tan importantes servicios al rey, don Alfonso VII, que entre otras mercedes le hizo donación de la villa de Alvires. [Su heráldica consta de un escudo de armas de sinople (campo verde oscuro, asociable tanto a la leyenda bucólica como al significado de cortesía) y un león rampante (significante del valor), de sable (negro, que significa prudencia), coronado de oro (por el ascendente real).] (Biblioteca Básica Multimedia F y G.)
\end{abstract}

Nuestra versión libre de El príncipe constante de Calderón propone un momento ficticio en la evolución profesional de Don Antonio, situándolo en un periodo cuando aún no se constituía la Cofradía de Nuestra Señora de la Novena (elite de actores de Madrid distinguidos por recibir la bendición eclesiástica y, por lo tanto, la dispensa del estigma de inmoralidad que pesaba en forma generalizada sobre el gremio teatral). ${ }^{74}$ Para asegurar la licencia de la Corona, los actores debían prestar servicios teatrales de evangelización en las fiestas de Corpus (jueves siguiente a la octava de Pascua), para lo cual se organizó esta cofradía (una cofradía es poco menos que una orden religiosa), auspiciada por la iglesia, cuya fundación fue firmada en Madrid en 1631, confirmada en 1632 (según Hdez. Glez.) y definitivamente aprobada en sus Constituciones el 21 de febrero de 1634 (Oehrlein. 248). Pertenecer a esta agrupación garantizaba la integridad moral del actor ante la iglesia, el rey y la sociedad. La Cofradía de la Novena (título abreviado), importa decirlo, existe hasta nuestros días (Oehrlein). Aquí proponemos que, en sus vísperas, Don Antonio haya tenido que presentar una especie de examen de ingreso.

La existencia espiritual del artista siempre y en todas partes está en peligro; ni un orden social autoritario ni un orden liberal están para él en absoluto exentos de riesgos; uno le asegura menos libertad; el otro, menos seguridad. Hay artistas que únicamente se sienten seguros en libertad, pero los hay que sólo pueden respirar libremente en seguridad. Del

\footnotetext{
${ }^{74}$ Otras cofradías teatrales fueron la de la Pasión y Sangre de Jesucristo (f. 1565) y la de la Soledad (f. 1567), que destinando sus ingresos a los hospitales y a la asistencia pública de niños abandonados piden y consiguen "que se deje representar todos los días, que no se impida representar a las mujeres, que no se cierren los teatros, y son, en resumen, los que se oponen a las pretensiones de cerrar los espectáculos por razones moralizantes" (Boves Naves. Semiótica de la escena. 428.)
} 
ideal de unir libertad y seguridad estaba en todo caso el siglo XVII muy lejos. (Arnold Hauser. Historia social de la literatura y el arte I. 552.)

En nuestra ficción, ${ }^{75}$ el joven actor acepta poner a prueba un texto aún no acabado del cada vez más célebre Calderón para acometer una penitencia en solitario -y despojado de sus credenciales de autor de comedias prestigioso- en una de las modalidades de teatro trashumante más humildes conocidas en ese tiempo: el bululú.

Habéis de saber que hay bululú, ñaque ${ }^{76}$, gangarilla, cambaleo, garnacha, bojiganga, farándula y compañía. El bululú es un representante solo, que camina a pie y pasa su camino, y entra en el pueblo, habla al cura y dícele que sabe una comedia y alguna loa: que junte al barbero y sacristán y se la dirá porque le den alguna cosa para pasar adelante. Júntanse éstos y él súbese sobre un arca y va diciendo: «agora sale la dama» y dice esto y esto; y va representando, y el cura pidiendo limosna en un sombrero, y junta cuatro o cinco cuartos, algún pedazo de pan y escudilla de caldo que le da el cura, y con esto sigue su estrella y prosigue su camino hasta que halla remedio (Rojas Villandrando, El viaje entretenido. Madrid: Imprenta Real, 1603.)

No podemos omitir, sin embargo, que las compañías de teatro trashumante estaban sujetas a normas estrictas. La normatividad española del siglo XVII exigía a las compañías trashumantes no acercarse a las ciudades importantes a menos de una legua de distancia (entonces equivalente a una hora a pie o a caballo, aproximadamente) de su plaza central, con el objeto de no perjudicar a las compañías legalmente establecidas (como ya en ese 1629 lo era la del mismo Antonio de Prado). ${ }^{77}$

Según Mateos Carretero (“El teatro en Parla...”), las condiciones de contratación solían ser muy parecidas para todos los teatristas (incluyendo a los trashumantes). Tomando como ejemplo un contrato del " 29 de julio de 1641 en la que la cofradía del Rosario de Parla, se concierta con Bartolomé Romero, autor de comedias, para representar en las fiestas de San Roque de dicha villa [Parla, cerca de Madrid]", refiere que:

\footnotetext{
75 Entiéndase esta ficción no tanto como un trabajo de creación, sino como una estrategia de lectura activa para cumplir con el propósito fundamental del texto dramático de ser puesto en escena.

${ }^{76}$ En el siglo XX, José Sanchis Sinisterra recrea El viaje entretenido de Rojas Villandrando con sus protagonistas Ríos y Solano en la comedia Ñaque o De piojos y actores (Estrenada en el Festival de Sitges en 1980 y editada en México: CONACULTA/El Milagro, 2008).

${ }^{77}$ Plenamente establecida y reconocida, "una compañía estaba formada por el autor o director, los actores y las actrices, los músicos y los bailarines, un encargado del vestuario, un cobrador y un apuntador, además de los figurantes, y podía tener hasta un total de unas treinta personas. Todos tienen un sueldo fijo por su trabajo y una seguridad" (Bobes Naves. Semiótica de la escena. 429.)
} 
El autor de comedias se comprometía a representar "dos comedias una por la mañana y otra por la tarde con sus loas y entremeses y bayles todo como lo pidieren los dichos mayordomos y a su contento y satisfaçion". A cambio la cofradía [del Rosario de Parla o de la Novena de Madrid o cualquier otro contratante] "le an de dar mill reales en moneda de bellon luego de contado el mismo dia de nuestra señora de agosto", es decir una parte del pago en moneda; además "le an de traer y a su compañía la vispera de nuestra señora con sus carros de a dos mulas desde madrid u otra qualquier parte donde estuviere el dicho autor como sea de tres leguas en contorno de desta villa a costas de los dichos mayordomos [...] demas de lo qual le an de dar los dichos mayordomos dos carros de a dos mulas para quando se baya de la villa el dicho autor para que le lleben a madrid o a otro lugar una legua en contorno desta villa", es decir otra parte del pago la realizaban en especie. (José Antonio Mateos Carretero. "El teatro en Parla en el siglo XVII".)

Seguramente el bululú no corría con tanta suerte. Escogimos situar la representación de Don Antonio en los alrededores de Barcelona, capital de Catalunya (Cataluña). ¿Por qué? Apenas en el siglo XV, durante el reinado de Fernando II de Aragón, Catalunya ha sido integrada a Castilla, así que conviene intentar suavizar los intereses catalanes independentistas. En efecto, en un futuro no muy distante, para 1640, durante el reinado de Felipe IV (coetáneo de Don Antonio y Calderón), Catalunya se sublevará (y precisamente en Corpus), aunque será nuevamente sometida. Para intentar salvar esa provincia es lógico suponer que la corona y la iglesia, en el contexto de sus acostumbrados mecenazgos, previeran promover expresiones táctico-estratégicas de integración nacional y unión lingüística-cultural como el teatro. ¿Qué mejor muestra de conciliación que enviar como embajador de buena voluntad en 1629 a un promotor cultural como Antonio de Prado, poniendo su orgullo madrileño a los pies de Barcelona? Por cierto, Barcelona es una ciudad cuya catedral (Santa Eulalia), plaza y barrios más antiguos se remontan a la época medieval, y sus ricas tradiciones culturales la mantienen hasta hoy precisamente a la vanguardia del arte y el teatro europeo (baste pensar en los Churriguera, en Gaudí, en Miró, en Tapies, en el Teatro Fronterizo, la Sala Beckett, José Sanchis, Sergei Belbel, la Fura dels Baus y hasta su fútbol). Hoy las aún existentes aspiraciones autonómicas (autonomía no siempre es igual a independencia) matizan la actitud separatista original (vigente en otros estados como Euskadi [el País Vasco]) con la defensa de la rica lengua catalana y una libertad y originalidad artística incuestionables, homologando así su nacionalidad esencial ${ }^{78}$

\footnotetext{
${ }^{78}$ Los catalanes han conseguido incluso representatividad en el Parlamento Europeo, y su condición de nacionalidad es tema recurrente de diálogo en las legislaturas españolas.
} 
a la cultura catalana. Además pensamos que el espacio representacional de esta penitencia fuera una ermita, una muy pequeña capilla en despoblado, concebida no para la celebración de misas, sino para el retiro y la meditación. Los dramas de tema religioso como $\mathrm{El}$ príncipe constante (se trata de la vida de un santo reconocido por la iglesia católica) siempre encontraron buen recibimiento en los templos, específicamente en los atrios (además de los autos y las vidas de santos, también están las pastorelas, vigentes hasta hoy), dada su utilidad evangelizadora pero, excepcionalmente, ¿qué pasaría cuando sin atrio, y en medio del yermo, el único espectador fuera Dios? Resulta interesante imaginar, si San Pablo decía: "El que canta ora dos veces", entonces ¿qué tanto valor tendrá la actuación como ejercicio espiritual? Muy a tono con la disciplina de la Compañía de Jesús, esta encomienda seguiría al menos la soledad, la reflexión y el claustro recomendados por San Ignacio de Loyola (1491-1556, faro indiscutible de la causa contrarreformista todavía para la época de Don Antonio y de Calderón.) La ermita imaginaria para este rito de pasaje bien hubiera podido asentarse en donde hoy está el Park Güell, jardín diseñado por Antonio Gaudí en la primera mitad del siglo XX, hogar de un fabuloso dragón, más o menos a una legua al norte de la Plaza Catalunya (centro de Barcelona). Esta locación estimula la imaginación, anima la espiritualidad y propicia la magia del arte, así que quizá cuando yo estuve ahí realmente, en $1996^{79}$, al querer inhumar mis melancolías en su jardín bien pude haber "descubierto" el manuscrito en un pequeño cofre enterrado, e intercambiado una reliquia por otras.

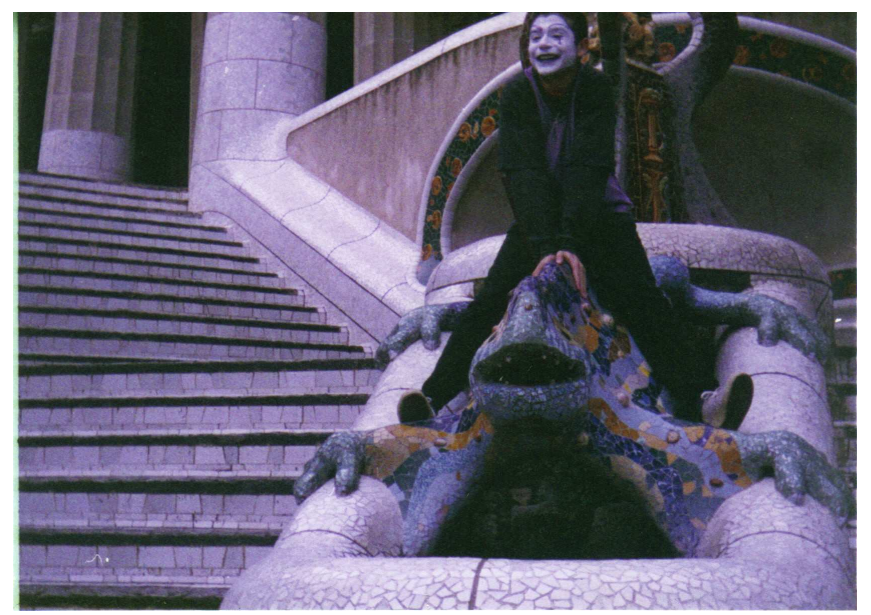

(Jorge Prado Zavala, como mimo, fundido en danza teatral con el Dragón de Gaudí. Foto por Verónica Musalem [1996].)

\footnotetext{
${ }^{79}$ De octubre a diciembre de 1996 cursé en Barcelona el Diplomado en nuevas tendencias de la producción y creación teatral, coordinado por José Sanchis Sinisterra.
} 
Proponemos que la fecha precisa de nuestra función ficticia haya sido un 23 de abril. Ese día se celebra la fiesta de Sant Jordi, santo patrono justamente de Catalunya, pero además de Aragón, de Génova, de Moscú, de Inglaterra y también de Portugal (patria del protagonista de El príncipe constante). ${ }^{80}$ Hoy Día Mundial del Libro, esta fiesta es coetánea a las fiestas de Corpus (temporada de los autos sacramentales), lo que supone evidentemente enfatizar la vocación de humildad del ritual artístico-religioso de nuestro actor. $^{81}$ Abril, por cierto, es un mes donde se mezclan los más antiguos ritos dionisiacos griegos con la Pascua cristiana (recordemos que Dionisio y Cristo comparten el sacrificio y la resurrección).

La mitología que enfrenta a Sant Jordi contra un terrible dragón para salvar a una princesa (como Perseo) es una alegoría de la eterna lucha -y victoria- del bien sobre el mal, y por ello se convirtió también en icono del caballero medieval ideal. Así, una orden de caballería asentada en una abadía en el desierto de Alfama, en Catalunya, llevó el nombre de Sant Jordi. ${ }^{82}$

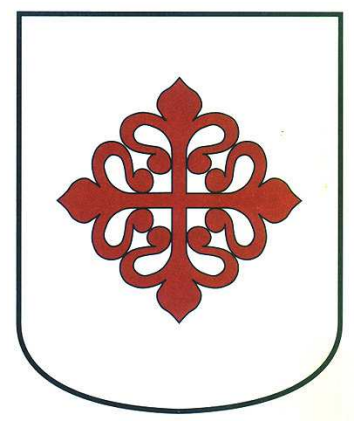

\begin{abstract}
La Orden de Sant Jordi fue fundada en el año 1201, por el rey Pedro II de Aragón y I de Cataluña, con el título de Orden de Sant Jordi de Alfama. Recibió este nombre dado que se le concedió el desierto de Alfama, a unas cinco leguas de Tortosa [obispado a orillas del Ebro, en Catalunya]. Para comprender la decisión real de fundar una Orden Militar, hay que tener en cuenta la personalidad del monarca y las circunstancias que rodearon su reinado.

Pedro era hijo primogénito de Alfonso "el Casto". Por el testamento paterno recibió Aragón, Cataluña y tierras en el sur de Francia, en tanto que su hermano, Alfonso, recibía Provenza, Millán y Gabaldá. A pesar de esta división, se conservó, cierta unión en los dominios catalano-occitanos, fortaleza por la alianza política entre ambos hermanos y porque a la muerte de Alfonso de Provenza, Pedro ejerció la tutoría sobre su joven sobrino. Pero para mantener la fastuosidad de su corte, al tiempo que un ejército bien pertrechado, Pedro precisaba dineros y éstos los obtenía mediante el impuesto de fuertes tributos que provocaban el descontento popular. Una de sus ideas fue ampliar sus dominios, emprendiendo la guerra contra los musulmanes a fin de arrebatarles tierras. Con este fin, en al año 1201, creyó muy interesante la creación de una Orden Militar cuyos caballeros le ayudaran en la empresa y a tal fin, se determinó a fundar la Orden de Sant Jordi, a la que se añadiría, "de
\end{abstract}

\footnotetext{
${ }^{80}$ Explica Fernando Martínez Laínez: "Según la leyenda, San Jorge ['Jordi’ en catalán] era un soldado de caballería romano que sufrió el martirio en tiempos del emperador Diocleciano, en el siglo II, por sus creencias cristianas. Esta leyenda, asentada en Europa en el siglo XIII, procede de Cilicia, y va unida a la lucha contra un dragón que tenía aterrorizada a la población y al rescate de una doncella víctima de la bestia." ("Entre la cruz y la espada", en Historia y vida. Agosto 2005. No. 449, año XXXVII. 37.)

${ }^{81}$ En esta fecha se conmemoran también los fallecimientos de Cervantes y de Shakespeare (m. ambos el 23 de abril de 1616 [aunque en diferentes calendarios]).

${ }^{82}$ Si había una abadía en Alfama consagrada a Sant Jordi, no sería improbable que hubiese una ermita sucursal en Barcelona; ambos lugares se ubican en Catalunya.
} 
Alfama", por el señorío que le dio de ciertas tierras, en realidad desérticas, muy próximas a la villa de Tortosa. La Orden decidió regirse por la Regla de San Agustín (confirmada en el año 1373).

Pedro emprendió la guerra y consiguió, con la ayuda de los caballeros de la recién creada Orden Militar, arrebatarles a los musulmanes de Valencia, Ademuz Castielfabib. El rey se centró en su alianza con Castilla y trató de apoderarse de la isla de Mallorca con una expedición que finalizó en fracaso. Alfonso VIII de Castilla solicitó su ayuda para combatir el poder musulmán y los aragoneses y catalanes así lo hicieron, participando en la batalla de las Navas de Tolosa. Entre las huestes del rey Pedro, se encontraban los Caballeros de la Orden de Sant Jordi, que no dudaron en acudir al llamamiento del monarca.

Vino un intento de apoderarse de parte del País Vasco, en detrimento de Navarra, y los que resultaron más beneficiados fueron los castellanos. La última etapa de su reinado se caracterizó por las convulsiones producidas en Occitania con motivo del catarismo [secta religiosa de la Edad Media que se propagó principalmente en Francia]. Pedro se encontró ante un dilema, por un lado deseaba conservar la amistad de los nobles del Languedoc y por otro, no quería enfrentarse al Papa que había decretado la Cruzada contra los Cátaros. La decisión papal de enviar a la nobleza franca contra los albigenses (cátaros) occitanos, obligó a Pedro a alinearse junto a estos. No sólo porque era su deber proteger a los que eran sus vasallos, sino que en aquel conflicto estaba en juego toda la política occitana de sus antepasados.

El problema afectaba también a la Orden de Sant Jordi, obligada, por un lado a combatir con el Rey que la había creado, y por otro, a entrar en combate con las fuerzas protegidas por el Papa, lo que repugnaba a su catolicismo. En suma, Pedro y los occitanos se enfrentaron a las tropas francas dirigidas por Simón de Monfort. La batalla se riñó a las puertas de Muret el 12 de septiembre de 1212; Pedro resultó derrotado y muerto y toda Occitania quedó en poder de los cruzados, con lo que las pretensiones sobre todas estas tierras quedaron definitivamente arruinadas.

No por esto la Orden de Sant Jordi dejó de existir. Permaneció; pero, de acuerdo con las crónicas, aunque sus caballeros eran hombres de bien probado valor en la guerra, en tiempos de paz llevaban una vida un tanto relajada. El rey Pedro IV de Aragón y III de Cataluña, llamado "el Ceremonioso", quiso darle nuevo vigor a la Orden para lo que solicitó del Papa Gregorio XI, su aprobación pontificia. Esta le fue otorgada y por parte del Rey, la Orden recibió el lugar de Aranda.

Ya por aquel tiempo, la Orden de Sant Jordi había iniciado su decadencia. Su convento era muy pobre, el número de caballeros era cada vez más escaso. De todos modos, participaron en cuantas empresas emprendió el rey Pedro "el Ceremonioso", un reinado caracterizado por convulsiones internas y guerras externas, entre las que destacó la denominada "de los dos Pedros", a causa del enfrentamiento de los aragoneses y catalanes del rey Pedro "el Ceremonioso", contra los castellanos del también Pedro, Rey de Castilla, apodado "el Cruel". A estas alturas, la Orden de Sant Jordi ya estaba en franca decadencia y así llegó hasta el reinado de Martín "el Humano".

Cuando sucedió en el trono a su hermano Juan, se encontraba en Sicilia y aún tardó casi un año en regresar a la Península. En 1397, Martín, juró los Fueros de Aragón y en la primera etapa de su reinado se esforzó en acabar con las rencillas que existían en varios puntos del Reino. Tuvo que pasar a Cerdeña para aplastar la rebelión de los Jueces de Arborea, que, ayudados por los genoveses, dominaban toda la isla a excepción de Cagliari, Alghero y Longorado, que permanecían fieles a la corona aragonesa.

Este rey tuvo la idea de fortalecer a la Orden de Sant Jordi, pero ya era muy tarde estando la misma en absoluta decadencia extinguiéndose poco a poco. Fue entonces cuando Martín "el Humano", concibió una solución: Unir la Orden de Sant Jordi con la de Montesa. El Papa Benedicto XIII, dio su aprobación y así, sin la menor dificultad, los Caballeros de Sant Jordi se integraron en la de Montesa. ¿Qué otra cosa podían hacer? La Orden de Sant Jordi de Alfama era como un débil riachuelo de escasas aguas comparado con el caudal ancho y caudalosa del río de la de Montesa. Pero, al menos, algo consiguió: que la Orden de Montesa, en lugar de utilizar la Cruz de los Calatravos como distintivo, aceptase portar la suya, la de San Jorge, la roja cruz del Santo.

Diez Maestres tuvo la Orden de Sant Jordi: El primero fue don Frey Juan de Almenara. El último, don Frey Guillén Castello, que fue a quien le tocó ver como su Orden desaparecía absorbida por la poderosa de Montesa. Durante su existencia, que duró dos siglos, menos algunos meses, tuvo que enfrentarse, no pocas veces, a la Orden de Calatrava, aun teniendo la misma Regla.

Siempre fue su rival y en no pocas ocasiones su enemiga. De todos modos, al fundirse Sant Jordi con Montesa, la primera dio a la segunda su insignia como emblema, la roja Cruz de Sant Jordi, y la segunda, al acoger a los miembros de la otra, su nombre y protección.

Una vez que se unieron, los Caballeros de Sant Jordi ya estuvieron siempre al servicio de su nueva Orden y con los de ésta participaron juntos, como un solo Cuerpo Militar, que eso fue lo que en realidad eran, en los días de gloria de Montesa, así como en los de su decadencia.

Se distinguieron bravamente luchando en Valencia, contra los sublevados nobles de aquella ciudad que, apoyados por el pueblo, formaron la llamada "Unión" contra el poder centralizador del rey Don Pedro "el Ceremonioso" de Aragón. Tomaron parte asimismo en las guerras de Italia, acompañando a Alfonso V. En un combate naval contra los genoveses los caballeros de la Orden de Montesa, en cuyas filas luchaban ya los antiguos de la de Sant Jordi, tomaron al enemigo cinco galeras e hicieron numerosos prisioneros.

Cuando en el año 1587, la Orden de Montesa fue incorporada a la Corona de Felipe II, por bula del Papa Sixto V, los antiguos caballeros de Sant Jordi ya no existían. De la Orden a la que pertenecieron tan solo quedaba, en el mejor de los casos, su cruz [análoga a la de la Orden de Avis del Infante Fernando de Portugal, que convierte los brazos de la cruz cristiana en cuatro letras "M" por María Madre de Dios] y un lejano recuerdo. (Biblioteca Básica Multimedia F y G.)

\section{El mismo Calderón de la Barca vincula a Sant Jordi con Fernando, el protagonista de El}

\section{príncipe constante, en:}

Yo he de ser el primero, África bella, que he de pisar tu margen arenosa, porque oprimida al peso de mi huella, sientas en tu cerviz [el "cuello" del dragón] la poderosa fuerza que ha de rendirte. (Jornada I.) 
Un análogo compromiso espiritual es el que obligaría a Don Antonio a abrazar su profesión más allá del mero oficio, como una vocación trascendental; no desde las armas, sino desde el arte dramático, y tomando como votos no la Regla de San Agustín, los Ejercicios Espirituales de San Ignacio de Loyola o los votos benedictinos (pobreza, castidad, obediencia), sino su libreto.

De todo lo dicho acerca del carácter ritual del teatro se deduce que, en el espacio de tiempo investigado [el Siglo de Oro Español], el actor tenía que cumplir una tarea mucho más amplia que la del mero recitado del texto ante un público. El término que mejor puede expresar su función es el de "perito ritual". Él tiene la tarea de trasladar a los congregados alrededor del suceso de la representación al mundo de la ilusión teatral. [.....] Con ello, el actor se manifiesta en una función cuasi sacerdotal. (Oehrlein. 61, 62 y 63.)

En nuestra ficción, el bautizo de fuego para el ministerio seglar de Antonio de Prado es $E l$ príncipe constante de Calderón. Como casi todos los grandes clásicos dramáticos, es una obra maestra destinada a evolucionar en nuevas lecturas, significados e interpretaciones. Como partitura, convoca a ser ejecutada pero también intervenida. Así seguramente la intervino Calderón desde 1629 hasta tener lista una versión publicable en 1636. Así la habría intervenido Antonio de Prado, como otros teatristas de su época, para adecuarla a las condiciones objetivas de representación. Así lo hemos hecho nosotros para extraer de la famosa comedia nueva (en tres jornadas) una tragedia "perdida" (en un acto único).

Por principio de cuentas, la adaptación dramatúrgica trata de conciliar diversas inconsistencias notables entre las distintas versiones conocidas en vida de Calderón (1629, 1636 y 1640). Entre ellas, por ejemplo, cambia el nombre del gracioso (Brito en 1636, Cutiño en 1629, ambos desaparecen en 1640). Fénix es en 1629 hermana del rey de Fez, pero se vuelve su hija ya para 1636. También algunos parlamentos importantes a veces aparecen en boca de Fernando y otras en la de su hermano Enrique. Etcétera. Si bien esto hubiera podido obedecer, entre otras causas, a errores de los editores, lo cierto es que siendo El príncipe constante una obra de juventud (Calderón tenía 29 años en 1629), el hecho de que su primera impresión fuera autorizada hasta 1636 deja pocas dudas en torno a haber sufrido esas alteraciones, correcciones y adecuaciones de la mano del propio autor; un autor en constante evolución, trabajando además bajo las presiones de las condiciones objetivas de cada representación: condiciones materiales (espacio escénico, tramoya); 
condiciones humanas (volatilidad de los elencos, pestes, censura, el favor del rey y la bendición de la iglesia); condiciones políticas (Portugal dejó de ser territorio español en 1640, después de una difícil guerra donde lusitanos [Fernando] y españoles [Calderón y Felipe IV] dejaron de verse como amigos); condiciones morales (hubiera sido arriesgado no matizar la posición del gracioso con respecto a las referencias directas a personas de la vida real), y quizá hasta condiciones religiosas ( $O$ Infante Santo es un icono que llevó a los portugueses a la victoria, lo que lo descarta como héroe para los españoles en medio de la citada guerra España vs Portugal). Lo que todo esto nos dice es que El príncipe constante nunca fue un texto consumado. Ello no demerita su calidad de obra maestra (otros ejemplos análogos son Hamlet de Shakespeare, Woyszeck de Büchner, el Réquiem de Mozart y En busca del tiempo perdido de Proust) pero, en tanto que partitura textual, nos convoca a nosotros a proponer su tejido final, cada vez en cada montaje y aun en cada función.

También se hicieron alteraciones en tanto que clarificaciones para el lectorespectador contemporáneo en el sentido de lo enunciado de acuerdo al contexto y argumento esenciales. Las adiciones han de ser consideradas como colaboraciones dramatúrgicas con Calderón para mantener la coherencia y la claridad de sentido de la obra en su versión minimalista. (Sabemos que Calderón aceptó algunas veces esta manera de trabajar.) Los versos agregados han procurado respetar la métrica (cuando no también la rima) de la escena intervenida (octosílabos y endecasílabos, principalmente) hasta donde fue posible. Además, hemos procurado el mayor respeto arqueofilológico mientras se sostuviera el significado del discurso, de modo que hemos conservado palabras como: "aqueste" [este], "estotro" [este otro], "agora" [ahora], de comprensión perdurable. Por otro lado, nos atrevimos a proponer un nombre propio para el Rey de Fez: "Abdalá", apoyándonos en el Tesoro de Covarrubias y en la historia verídica del rey de Fez durante la campaña de Tánger (que fue 'Abd al-Haqq 'Ab Allah III). En todo caso, intentamos que la adaptación significara en sí misma un profundo análisis filológico ${ }^{83}$ y las ponderaciones hechas al respecto se asientan a pie de página.

Hemos procurado, sin embargo, que nuestra intervención e interpretación siguiera usos y costumbres del teatro profesional calderoniano. Así, partiendo del análisis actancial

\footnotetext{
${ }^{83}$ Un análisis filológico y arqueofilológico en el sentido de estudiar una cultura tal y como se manifiesta en su lengua y especialmente en su literatura, además de reconstruir, fijar e interpretar el texto. (Vid. DRAE: "filología".)
} 
desarrollado en el capítulo II y de la lectura trágica propuesta en el capítulo III, la anécdota, acciones, diálogos y personajes del texto original han sido adecuados tal y como lo haría un bululú, un ejecutante en solitario del Barroco español. Incluso los recortes, elipsis, cambios de orden del texto, alteraciones o adiciones al verso y otras libertades no difieren mucho de las que tendría que haber hecho Antonio de Prado con el manuscrito de Calderón para hacer de él un folio de actor, es decir, lo que hoy se denominaría "texto espectacular" (De Toro. Semiótica del teatro), o sea, una partitura personal. Ello no significa que se simplifique el trabajo de montaje para el director contemporáneo, por cierto, dado que tendrá que resolver dos situaciones ficcionales superpuestas: la del periplo mortal de Fernando (el drama de Calderón) y la de la iniciación ritual de Don Antonio (su contexto cultural de producción escénica). El desarrollar una concepción de puesta en escena como un ejercicio ritual, y precisamente en un espacio religioso, es coherente con la estética mística-espiritual del Barroco analizada en el capítulo IV. ${ }^{84}$

Con respecto a la producción, hay que señalar que una producción ostentosa tendría que resolver "complicaciones como vuelos, descensos del techo, caídas por el escotillón o apariciones tras las cortinas, como ocurre en otras comedias palaciegas y religiosas, así como en algunos autos sacramentales" (Erasmo Hernández González. "Estudio de La despreciada querida de Juan Bautista Villegas"), incluidos el mar, los barcos, los ejércitos, las batallas y el fantasma en El príncipe constante. A falta de recursos materiales, el apelar a la imaginación en la brevedad del espacio de una humilde ermita resuelve gran parte del problema. El papel imaginativo (activo y creativo) del actor y del espectador siempre ha sido considerado y apelado por los dramaturgos.

¿Quién tuviera una musa de fuego para escalar el cielo más resplandeciente de la creación! ¡Un reino
por teatro, príncipes como actores y monarcas para espectadores de la escena sublime! Pues
aparecería entonces el belicoso Hal, bajo su auténtica identidad, con el porte de Marte, y a sus pies
veríamos, atados como perros, el hambre, la guerra y el fuego, dispuestos a ser empleados. Pero
todos vosotros, nobles espectadores, perdonad al genio sin llama que ha osado traer a este lugar un
tema tan extraordinario. ¿Acaso puede este reñidero albergar los inmensos campos de Francia?
¿Podría esta "O" de madera ${ }^{85}$ acoger los cascos que sembraron el pánico en el cielo de Azincourt?
Perdón, ya que una reducida figura ha de representaros un millar en tan corto espacio, y permitid que
sea la fuerza de vuestra imaginación la que dé forma a esas grandes cifras. Imaginad que en este
recinto coexisten dos poderosas monarquías, cuyos frentes, amenazadores y dispuestos al conflicto,

\footnotetext{
${ }^{84}$ Cuando en 1968 Grotowski trajo a México su montaje de El príncipe constante, solicitó y le fue concedido un espacio religioso que conservara el misticismo de la obra: el Convento del Desierto de los Leones.

${ }^{85} \mathrm{La}$ "O" de madera se refiere al edificio del Globe Theatre donde fue representada esta obra de Shakespeare, cuya arquitectura es descrita así de la manera más sencilla.
} 
se hallan separados por el peligroso y estrecho mar. Suplid mis carencias con vuestra mente. Multiplicad un hombre por mil y desplegad un ejército imaginario. Cuando hablemos de caballos, pensad que los veis pisar con sus magníficos cascos el blando suelo, porque son vuestras imaginaciones las que deben hoy vestir a los héroes, transportarlos de aquí para allá, cabalgar sobre las épocas, amontonar en una hora los acontecimientos de muchos años. Por lo cual os ruego que me admitáis a mí, el Coro, en esta historia, a mí que vengo aquí, a manera de prólogo, a solicitar vuestra amable paciencia y a pediros que escuchéis y juzguéis suave e indulgentemente nuestro drama. (William Shakespeare, Enrique V: I, i.)

En este sentido, una producción austera como la que tendría que desarrollar un actor en las condiciones del bululú (lejos de los corrales de comedias, las grandes plazas y el teatro palaciego) de los siglos XVI y XVII “encaja en el molde de las escenificaciones más sencillas (explicadas entre otros por Rennert [1909], Díez Borque [1978], Varey [1976], Ruano de la Haza [1988] y Rodríguez G. de Ceballos [1989]), debido a que los actores entran y salen por la derecha y por la izquierda delante de las cortinas, con un mobiliario escaso" (Erasmo Hernández González. "Estudio de La despreciada querida de Juan Bautista Villegas"), con el protagonista a lo mucho subido "sobre un arca" (como indica Rojas Villandrando), y con los deberes de ser más imaginativa y sugerente, procurando una actuación "con la máxima destreza y naturalidad" (como recordaba Cervantes a Lope de Rueda). ${ }^{86}$
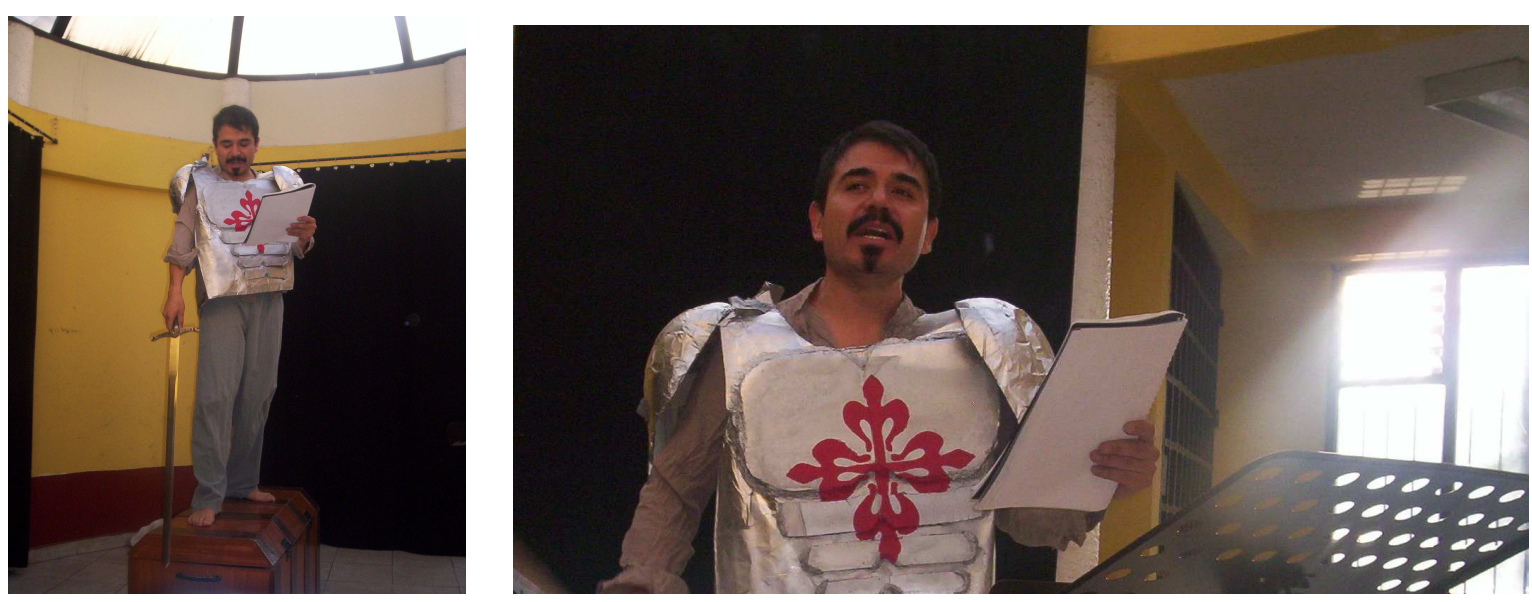

(Ensayos de El príncipe constante en su versión bululú. Junio de 2011.)

\footnotetext{
${ }^{86}$ Rojas Villandrando implica con suficiente claridad cómo el bululú debía ejercer su oficio fuera de los ámbitos "naturales" de la comedia nueva: "[...] entra en el pueblo, habla al cura y dícele que sabe una comedia [de Lope de Rueda, de Lope de Vega, de Calderón, etc; da igual] y alguna loa: que junte al barbero y sacristán y se la dirá porque le den alguna cosa para pasar adelante. Júntanse éstos [obviamente no en un corral de comedias, ni en palacio alguno, ni en una plaza grande] y él súbese sobre un arca y va diciendo: «agora sale la dama» y dice esto y esto [haciendo todos los personajes]; y va representando, y el cura pidiendo limosna [ipara el solitario actor!] en un sombrero [...]" (El viaje entretenido.)
} 
Recordemos que en nuestro siglo XXI cada vez es más complicado hacerse de los recursos económicos y materiales para realizar una súper-producción como las que sugiere Calderón. No disponemos de subsidio alguno público ni privado para nuestro fin artísticoliterario. En nuestra búsqueda por una versión holística (texto+representación) de $E l$ príncipe constante, al optar por apoyarnos en un minimalismo (estudiado en el capítulo V) simultáneamente contemporáneo (Sanchis, Brook, Grotowski) y Barroco (por el bululú) se nos abre el acceso a una lectura no meramente contemplativa o crítica, sino justificadamente activa y, necesariamente, propositiva: Una concepción de puesta en escena sencilla que facilitará transportar y acercar el Teatro Dorado a espacios difíciles o de escasos recursos, donde no haya arquitecturas propiamente teatrales o donde no se puedan costear majestuosos elencos, vestuarios, escenografías ni efectos de tramoya.

Una tarea muy importante de los estudios literarios, muchas veces olvidada en las esferas elevadas del academicismo, es la de procurar la aproximación de la obra al lector y no el distanciarlos. Paul De Man hace la siguiente crítica acerca de los estudios humanísticos tradicionales: “-La filosofía crítica, la teoría literaria, la historia- se parecen entre sí por el hecho de no parecerse a aquello de lo que derivan.” (De Man. La resistencia a la teoría: 130.) En este sentido, la literatura dramática debería ser estudiada con más razón desde puntos de vista que privilegien su carácter representacional, como el que aquí proponemos desde la perspectiva del actor, puesto que la representación teatral es la mejor modalidad de lectura del texto dramático. Como hemos podido ver hasta aquí, una lectura escénica no tiene por qué ser una lectura superficial sino, desde un principio, analítica.

Por lo pronto, todo esto nos posibilita una adaptación minimalista, factible de ser producida y que se acerque al público contemporáneo pero que, al mismo tiempo, no traicione su espíritu original. Más que como un trabajo creativo personal, esta adaptación debe considerarse como el producto de la lectura activa de un actor ante condiciones objetivas de representación. En suma, los elementos hasta aquí expuestos plantean cómo hubiera sido representado El príncipe constante en el siglo XVII por un humilde actor solitario, dejando al alcance de la mano todas las posibilidades para una representación contemporánea leal. ${ }^{87}$

\footnotetext{
${ }^{87}$ Se podría pensar que con esta adaptación busco yo alguna redención familiar de la Casa De Prado. Empero, debo decir que no conozco un solo dato fidedigno que vincule con certeza a la familia de actores españoles
} 


\section{Requerimientos técnicos:}

1. Espacio escénico o representacional: Idealmente, un espacio cerrado de tamaño mediano: un teatro de cámara, un salón de ensayos, un aula escolar, una sala de juntas o, mejor aún, una capilla. De cualquier manera, con pocas adecuaciones la obra puede representarse también en un Corral de Comedias, un Teatro a la Italiana, un Foro Isabelino o en cualquier otro espacio escénico. Se requiere de caja negra, telón de fondo o muro donde se pueda tender el decorado específico del Icono de Sant Jordi. Asimismo, se solicitan mamparas o practicables similares que permitan aforar, en su caso, el espacio para sugerir el oratorio de la Ermita de Sant Jordi, y colgar candelabros y reliquias (cruces, espadas, escudos, floreros).

2. Público: La obra es apta para todo público. Esta concepción escénica no contempla lenguaje altisonante, ni escenas pornográficas, ni apologías de la violencia.

3. Duración: Aproximadamente 90 mins. (una hora y media.)

4. Patio de butacas (disposición del público): Frontal, semicircular o en herradura.

5. Telares: Los tradicionales para telón de fondo, bambalinas y piernas, en negro o cualquier otro color oscuro: rojo, verde, café o azul.

6. Iluminación: áreas especiales y dimmers.

7. Sonido: Altavoces, reproductores de cd y mp3 para música y efectos especiales grabados, y micrófono para potenciar efectos sonoros en vivo.

A continuación ofrecemos la partitura actoral (el "texto para la representación", en términos semiológicos) de El príncipe constante. No omitimos advertir que, dada la naturaleza de la adaptación en un formato de manuscrito apócrifo (un hipotético borrador anterior al Manuscrito 15.159), acompañan a los versos originales de Calderón los que habría insertado el bululú para facilitar y hacer coherente su ejercicio representacional, así como citas y comentarios entre algunas escenas a modo de reflexiones sobre el oficio actoral y la obra misma. Podemos imaginar que así es como el manuscrito fue encontrado. Las notas a pie de página precisan y amplían la información sobre este experimento arqueofilológico.

\footnotetext{
del Barroco con la del actor-investigador mexicano del siglo XXI que esto escribe y es servidor de ustedes. La
} ocasión no me impide, de todos modos, festejar la casualidad. 


\title{
EL PRÍNCIPE CONSTANTE
}

\section{"La tragedia perdida del Infante Santo Fernando de Portugal", de Don Pedro Calderón de la Barca, ${ }^{88}$ tal y como habría sido interpretada en bululú por \\ Don Antonio García de Prado \\ en la ermita de Sant Jordi, una legua al norte de Barcelona, la madrugada del 23 de abril de 1629, como penitencia para ingresar a la Cofradía de Actores de Nuestra Señora de la Novena de Madrid}

\author{
Dramatis Personae (Personas que hablan en ella) ${ }^{89}$ : \\ Don FERNANDO, Príncipe de Portugal ${ }^{90}$, \\ Don ENRIQUE, hermano de Fernando y también Príncipe de Portugal ${ }^{91}$, \\ El REY ABDALÁ de Fez ${ }^{92}$, un monarca viejo, y \\ FÉNIX, doncella, hija del Rey Abdalá de $\mathrm{Fez}^{93}$, actuados todos por \\ Don ANTONIO García de Prado, como actor bululú ${ }^{94}$
}

\begin{abstract}
${ }^{88}$ Adaptación por Jorge Prado Zavala para la puesta en escena de El príncipe constante y esclavo por su patria, de Pedro Calderón de la Barca, a partir de la edición digital de la Biblioteca Cervantes basada en el Ms. 15.159 de la Biblioteca Nacional de España (ésta cotejada con la edición crítica de Fernando Cantalapiedra y Alfredo Rodríguez López-Vázquez; Madrid: Cátedra, 1996), y en la edición de Empresa Latinoamericana de Comercio Exterior (Panamá: 1977) apoyada primordialmente en la edición princeps (Madrid: 1636). No se consideró la edición de 1640 (Madrid) por propiciar el confundir los personajes de Muley con el del rey de Fez.

${ }^{89}$ Otros personajes, que omitimos como parte del supuesto de tratarse tanto de un manuscrito inacabado como de una estrategia del bululú para representar como actor único una obra grande, son: Don Juan de Silva (Conde de Miralva, no confundir con Juan de Portugal), el general moro Muley, el gracioso Brito, el rey de Portugal Alfonso (sobrino de Fernando), el rey de Marruecos Tarudante, las damas de compañía moras Rosa, Estrella, Zara y Celima (variables entre ediciones); el soldado moro Zelín y el esclavo Silveira (igualmente variables); soldados portugueses, cautivos y moros.

${ }_{90}$ Vale la pena recordar que Portugal fue parte del imperio español de 1580 (cuando al fenecer el monarca lusitano Don Sebastián sin heredero, Felipe II de España reclamara otros derechos de sucesión) a 1640 (con la guerra independentista portuguesa), lo cual reforzaría en 1629 el interés de Calderón por un héroe no sólo religioso, sino además nacionalista. Sin embargo, en la época de Fernando todavía Portugal vivía su primera independencia y la monarquía estaba en manos de la Casa de Avis.

${ }^{91}$ Enrique de Portugal, el Navegante, hijo de Juan I de Portugal, nacido en Oporto (1394-1460). Fue gran promotor de viajes para descubrir nuevas tierras. Hermano del infante don Fernando.

${ }_{92}$ Calderón presenta al Rey de Fez. Hoy sabemos que su nombre verdadero fue 'Abd al-Haqq 'Ab Allah III. Nosotros en nuestra adaptación lo simplificamos como Abdalá, siguiendo la misma lógica que usó Calderón para asignar los nombres a sus personajes, es decir, a partir de la historia y la geografía real de Marruecos: el general Muley (Muley Idris conquistó Marruecos para el Islam en el siglo VIII) y el rey Tarudante de Marruecos (la ciudad de Taroudannt fue un centro de resistencia contra los portugueses en el siglo XVI), nobles mahometanos. (Información del Ministerio Marroquí de Turismo y libros de consulta.) Calderón separa como dos reinos diferentes a Fez y Marruecos. El Tesoro de Covarrubias indica:
\end{abstract}

A B D A L A,muchos RevesMoros tuuieronefe nombre Abdala Arraez de Cartago fue Alifa VI.tras fuhermano lezid, Abdala $\mathrm{H}_{3}$ lifa de Caruan, $\mathrm{Ab}$ dala Mouahedin Rey de Marruecos. Abdalaben Mahomet grã perieguidor de los Chriftianos. Abdala Moshadin, Morode Africa, que paffò a Italia, y hi zoen ellagraneitrago.

(Tesoro de la lengua castellana, por Sebastián de Covarrubias Orozco. Madrid: 1611, p. A3.)

${ }^{93}$ Fénix es hermana del Rey moro en el original de 1629. Hacerla su hija (en 1636) enfatiza su subordinación. ${ }^{94} \mathrm{La}$ anécdota, estructura, acciones, diálogos y personajes del texto original han sido editados para posibilitar su interpretación a través de un ejecutante único siguiendo los usos y costumbres de los teatristas del siglo XVII (poetas, autores, actores y aun editores). Cuando en la tradición española del Barroco este protocolo era realizado por un artista trashumante en solitario (sin importar si el drama había sido escrito para más personajes), entonces, entre toda la genealogía teatral profesional, tal actor recibía la denominación de bululú. 
(Sale Don ANTONIO al centro del salón único y estrecho de la ermita. Cansado está de mucho caminar. Se le ve sediento, sudoroso y con la piel quemada por el sol. En una mano lleva una lámpara que ilumina al fondo una pintura de "Sant Jordi y el dragón”. Con la otra mano arrastra un arca de donde sacará toda clase de objetos de utilería, armas, vestuario y maquillaje y que, al mismo tiempo, fundamenta la escenografía al funcionar como barco, templete, muralla, torre, etc. La hora es laudes ${ }^{95}$, es decir, entre las cinco y seis de la mañana, antes de rayar el alba.)

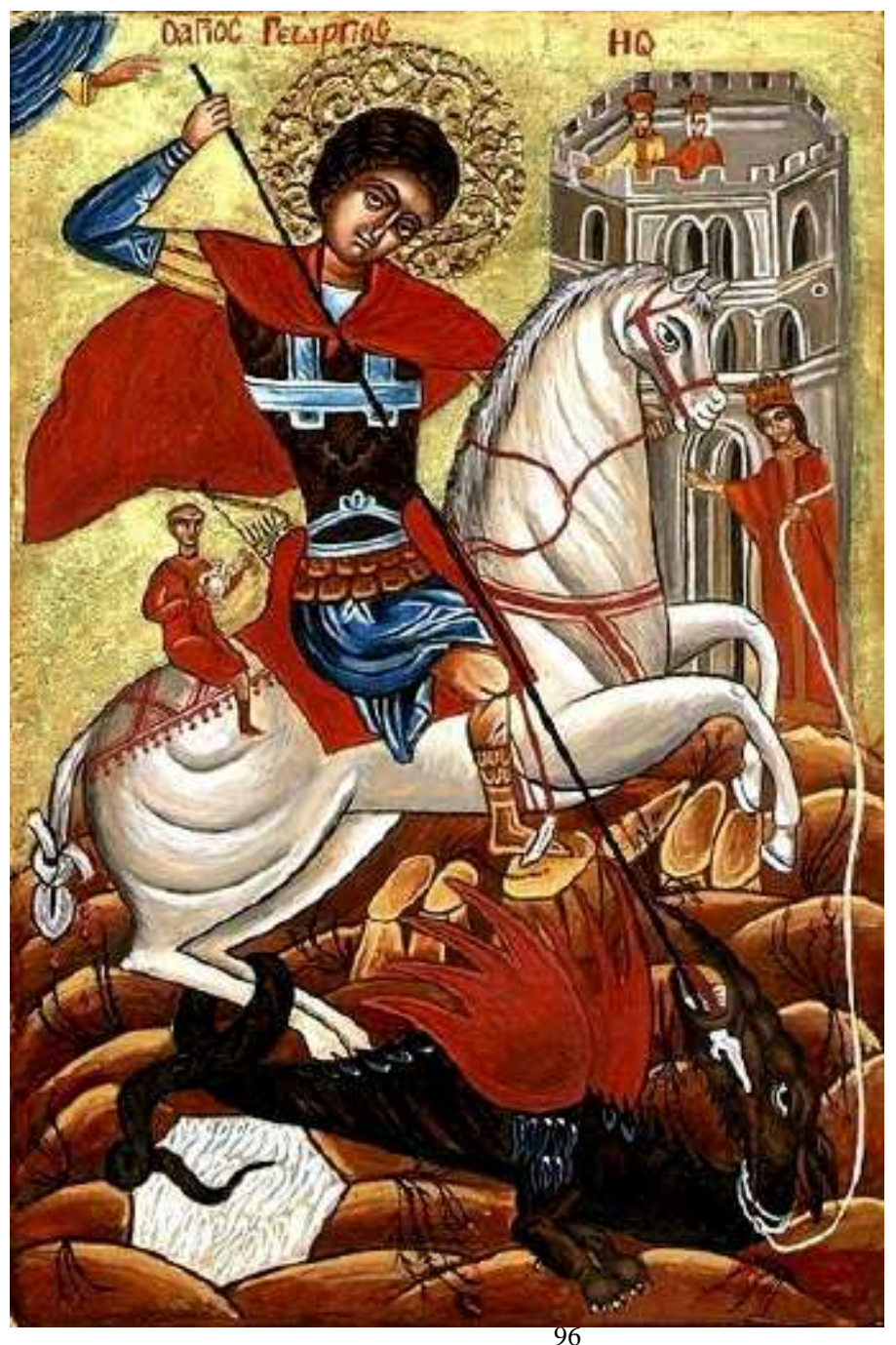

(Icono de Sant Jordi.)

\footnotetext{
${ }^{95} \mathrm{La}$ información de los horarios está planteada según la regla benedictina (citada por Umberto Eco. El nombre de la rosa. 15).

${ }^{96}$ Entre muchas imágenes hemos escogido este códice medieval -aparentemente griego ortodoxo- donde el caballero (con su escudero) se enreda en contienda con el monstruo, ya herido, el cual aparece atado por el cuello a la princesa, quien a su vez espera su propia salvación o sacrificio a los pies de una torre y a orillas de un lago (paradigmas geométricos ambos) en medio de toscas dunas, mientras los reyes contemplan la escena. La dama tiene atado al dragón, éste al caballo y éste último su propia cola. El caballo recuerda mucho a los unicornios por la proporción de la cabeza y las múltiples ataduras que lo conectan finalmente a la princesa. La princesa, idealmente doncella, está coronada como la reina, y no viste de blanco como en la mitología del unicornio sino del color de la pasión amorosa; los reyes (sus padres) aparecen alejados y seguros en lo alto de las almenas. El rostro sobrenatural del escudero hace pensar en un demonio (como los de Hieronymus Bosch "El Bosco" o los de Bruegel El Viejo) o un duende de la conciencia, y carga con arco, flechas y una cantimplora con agua o licor. El rostro luminoso del santo guerrero es sereno, meditabundo, y mira no hacia su presa sino al espectador. Sus cabellos están rigurosamente recortados y peinados. No hay una sola cruz en todo el cuadro, pero del cielo asoma una mano diestra
} 
ANTONIO: "Sabios y críticos bancos,

gradas bien intencionadas,

piadosas barandillas,

doctos desvanes del alma,

aposentos, que callando

sabréis suplir nuestras faltas;

infantería española,

porque ya es cosa muy rancia

el llamaros mosqueteros;

damas que en aquesa jaula

nos dais con pitos y llaves

por la tarde alboreada:

á serviros he venido." 97

¿Para qué me engaño? Cierto es que esta madrugada del 23 de abril del Año de Mi Señor de 1629 no estoy en el Corral del Príncipe, ni en el de la Cruz $^{98}$, ni en la Plaza Mayor ${ }^{99}$, ni en el Alcázar del rey ${ }^{100}$. La verdad es que he venido a pie

haciendo una bendición. La forma en la que es acometido el dragón es similar por cierto a la manera como se labra la tierra para cultivarla (El nombre "Jordi" o "Jorge" [en español] significa "agricultor").

${ }^{97}$ Quiñones de Benavente, Loa con que empezó en la Corte Roque de Figueroa, cit. en Oehrlein, 59. María del Carmen Boves Naves describe en el Corral de Comedias: "diversos espacios para el público en la sala: el patio, elemento central, donde había localidades de asiento para los más pudientes, en bancos frente al escenario y en los laterales, y localidades de a pie para los 'mosqueteros', llamados así por el barullo que armaban; en la parte de atrás y un poco elevada, estaba la cazuela [o jaula o corredor], a la que se accedía por una escalera lateral, destinada a las mujeres, que acudían masivamente al teatro; en ella había largos bancos y un acomodador llamado 'apretador de cazuela'. [...] Los balcones y ventanas de las casas que daban al patio, cuando el corral era improvisado o en la calle, o bien las galerías laterales y de fondo cuando se construyeron los edificios, eran divididos en los denominados aposentos [o troneras], especie de palcos, que eran propiedad de nobles o los alquilaban. En la última planta, bajo techo se habilitaban los desvanes, destinados generalmente a religiosos. Tanto los aposentos, como los desvanes, podían llevar, sobre todo si se destinaban a las damas o al rey [p. e. Felipe IV], celosías para impedir que los ocupantes fuesen vistos por el público del patio o de la cazuela. [...] Había también un aposento llamado tertulia donde se reunían los entendidos y discutían sobre el valor de las obras y de la representación y cuyo juicio interesaba mucho a los autores. [...] A un lado del patio estaba la alojería, especie de bar público, donde se vendía la aloja (miel con agua [hidromiel]) y otras bebidas y también frutas" (Semiótica de la escena. 425 y 426.)
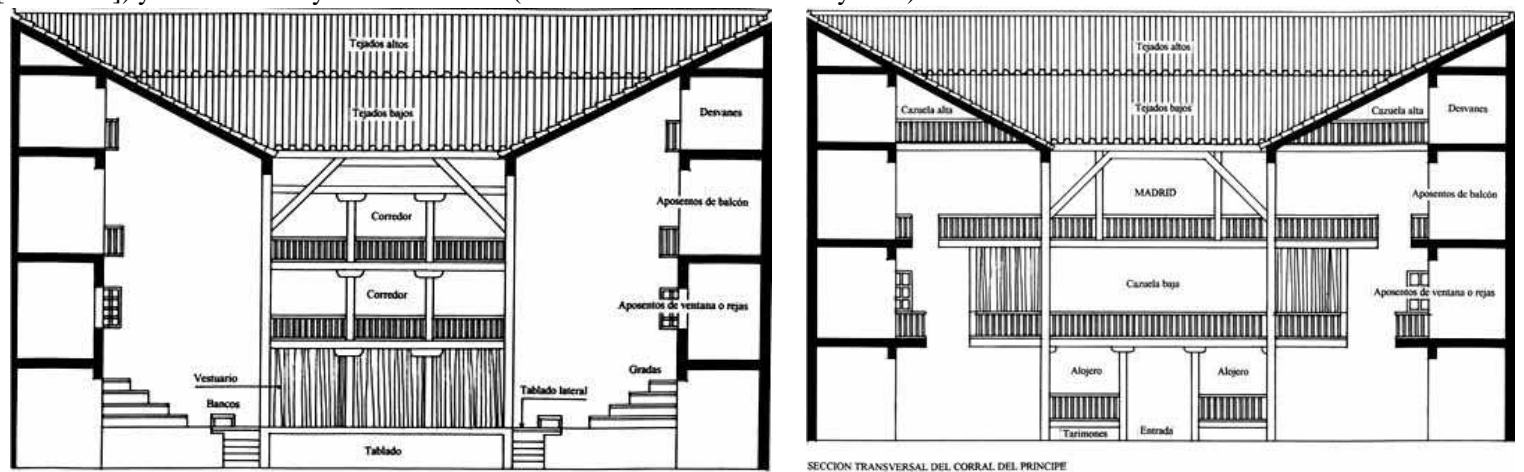

(Cortes transversales del Corral del Príncipe [escenario y entrada], en Madrid, por Ramón Rodríguez, Universitat de Valencia.)

${ }^{98}$ Los dos espacios representacionales más importantes de Madrid en el siglo XVII. Dice Boves Naves: "Los primeros corrales se hicieron en Valencia, Toledo y Sevilla, luego en Madrid. Se conservan algunos planos de Valencia y Madrid, y se mantiene un hermoso corral en Almagro (Ciudad Real). Entre los más conocidos y famosos destacan el Corral de la Cruz (1579), y el Corral del Príncipe (1582), que sustituyeron a otros improvisados, como el Corral de la Pacheca. En Sevilla se conocen el de la Huerta de Doña Elvira, el de las Atarazanas, el de don Juan, etc. Y prácticamente los hubo en todas las ciudades de España. En 1981 se descubrió un corral en Alcalá de Henares, construido en 1601" (Semiótica de la escena. 430 y 431.)

${ }^{99}$ En la Plaza Mayor, y en el Consejo de Castilla, el Ayuntamiento de la Plaza de San Salvador y la Puerta de Guadalajara (sitios todos de Madrid) se representaban los autos sacramentales (Oehrlein. 43.)

${ }^{100}$ El Salón Dorado, la Pieza de las Audiencias y la Armería para los pajes, todos en el Alcázar (que en ese tiempo eran denominados todos juntos "Palacio"), así como las habitaciones del rey y de la reina y los 
pidiendo limosna desde Madrid hasta este lugar: la ermita de Sant Jordi, una legua al norte de Barcelona, para cumplir la extraordinaria penitencia de dar buena fama a la lengua castellana a través del arte teatral. Llegué con el cura de Sant Jordi, le expliqué que soy Antonio García de Prado, famoso actor, y que estoy aquí para representar yo solo, sin más compañía, o sea como comediante bululú, esta obra: $E l$ príncipe constante, escrita con prisas y todavía sin pulir por mi joven amigo Pedro Calderón. Es la trágica historia de cómo el infante don Fernando, príncipe de Portugal y maestre de la orden de caballería de Avis, intentó arrebatar el puerto de Tánger a los moros, con la ayuda de su hermano Enrique el Navegante; pero cayendo preso -y al no aceptar su rescate con la entrega de la estratégica ciudad de Ceuta- es maltratado hasta morir, defendiendo con su vida la fe cristiana. Con ello espero merecer la bendición de Dios y la licencia de Felipe IV para formar parte de la Cofradía de Actores de Nuestra Señora de la Novena, en Madrid, y así demostrar que soy un gran actor. ¿Pero con qué me he encontrao $?^{101}$ Ayer el cura me confesó, me roció agua bendita, me dijo que ayunara el día completo y que ya en la noche en esta ermita, a solas, sin público para calificar mi trabajo, hiciera oración y diera la función. ${ }^{102} \mathrm{Me}$ ha advertido (habla con acento catalán, señalando al icono del fondo): "Aquí velaron sus armas muchos caballeros de la Orden de Sant Jordi. ${ }^{103}$ ¿Cuáles son las armas del actor?" No he sabido contestarle. "Persevera como el Infante lusitano Fernando, búscate a ti mismo y encontrarás el aplauso de Dios", así se despidió. ${ }^{104}$ Así que: aquí y ahora solamente quedamos yo y mis circunstancias. $^{105}$ (Toma el manuscrito que primero lee, luego recita y finalmente interpreta:) "El príncipe constante, por Pedro Calderón de la Barca. Los personajes..." -al menos los que tal vez yo podría representar- “... son: el príncipe Don Fernando de Portugal, su hermano Enrique el Navegante, el rey Abdalá de Fez y su hija la doncella Fénix. La escena es en la ciudad de Fez y sus contornos, y desde luego en los del puerto de Tánger. ${ }^{106}$ La acción comienza el 13 de septiembre del año $1437^{107}$ con el Infante Don Fernando y su muy breve armada llegando a las costas africanas..."

\section{(Dispone lo necesario. Toca un clarín y hace ruido de desembarcar.)}

jardines integraban en Madrid el teatro cortesano. Otros escenarios se dispusieron para el rey en El Escorial, Aranjuez, Toledo, el Pardo y La Zarzuela (Oehrlein. 32 y 33.)

${ }^{101}$ Encontrao: contracción vulgar de "encontrado".

${ }^{102}$ La reconciliación (o confesión), el agua bendita, el ayuno y la oración en soledad se consideraban parte del rito de pasaje del aspirante a caballero.

${ }^{103}$ Aunque quizá todos se habrían ordenado en su catedral gótica en el obispado de Tortosa (en Tarragona).

104 Como con todo documento de trabajo, el manuscrito podría contener adecuaciones especiales y anotaciones hechas por Don Antonio, en el riguroso modo como un ejecutante trataría su partitura. Durante la función, especialmente en los cortes reflexivos metateatrales, ha de ser visto haciéndolas.

${ }^{105}$ El aquí y el ahora son la condición efímera tanto de la existencia humana (Heidegger, Ortega y Gasset) como del acontecimiento teatral. A partir de ello, el actor activa una conciencia ontológica peculiar: Ser el que se es y ser el personaje.

${ }^{106}$ El drama abarca las ciudades de Fez (antigua capital del reino de Marruecos, centro económico y religioso); Ceuta (plaza al norte de Marruecos, punta sur del Estrecho de Gibraltar, tomada por Don Juan de Portugal en 1415, pasó a poder español en 1688), y Tánger (puerto de Marruecos en el Estrecho de Gibraltar, SO de Ceuta, antigua Tingis). (Información del Ministerio Marroquí de Turismo y libros de consulta.)

${ }^{107}$ En esta fecha inició el sitio de Tánger por los infantes Fernando y Enrique. (Ver Balbuena Briones: 114.) 
ANTONIO: (Canta mientras desembarca.) "A la conquista de Tánger, contra el tirano de Fez, al infante don Fernando envió su hermano el rey.",108

\section{(Don ANTONIO se caracteriza como don FERNANDO.)}

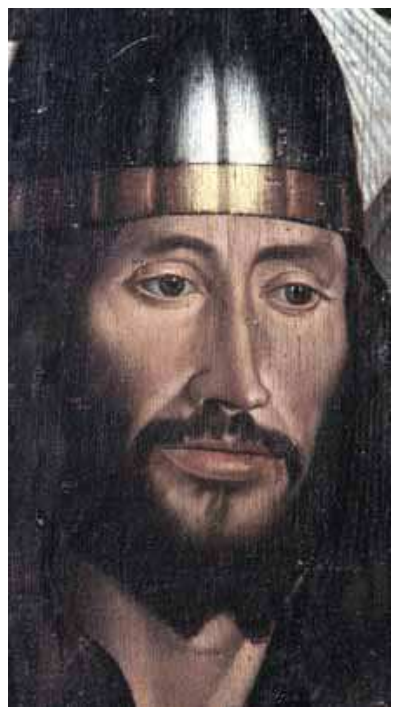

(Painel do Infante Santo, de Nuno Gonçalves. Siglo XV. Museu Nacional de Arte Antiga de Lisboa.)

FERNANDO: $\quad$ Yo he de ser el primero, África bella, que ha de pisar tu margen arenosa, porque oprimida al peso de mi huella, sientas en tu cerviz de dragón ${ }^{109}$ la poderosa

fuerza que ha de rendirte. ${ }^{110}$ (Baja del "barco".) $)^{111}$

Desierta esta campaña y esta sierra los árabes ${ }^{112}$, al vernos, han dejado.

Tánger las puertas de sus muros cierra.

Todos se han retirado a su sagrado. Reconoced las tierras con cuidado,

\footnotetext{
108 Canción original de la obra de Calderón de la escena IX de la Jornada II, interpretada por un cautivo, utilizada para la estrategia bululú de don Antonio como una especie de obertura. Aprovechamos la ocasión para hacer notar otras diferencias. Un diferendo importante es el que plantea la línea "contra el tirano de Fez" (1636) al suplir a "contra el bárbaro Muley" (1629), la cual alteraba el sentido de la nobleza moral que el autor concedió al general moro.

109 Se agregó a "tu cerviz" el complemento “de dragón” para poner en evidencia cómo Calderón alude al arquetipo universal del héroe que abate al monstruo del mal, como Perseo, Sigfrido o Sant Jordi.

${ }^{110}$ En esta estrategia bululú hemos apostado a que Don Antonio habría decidido iniciar su representación in medias res de la obra original, y no necesariamente desde su inicio.

${ }^{111}$ Muchas acciones y diálogos correspondientes a otros personajes en el texto original han sido incorporados a Fernando. En algunas ediciones quien habla y desembarca primero es Enrique el Navegante, hermano del protagonista. Por ser Fernando quien toma la decisión de intentar la conquista de Tánger, nos atenemos aquí a las ediciones que privilegian estas palabras en su boca.

112 "Alarbes" en otras ediciones. Calderón también usa "alárabes". Usamos "árabes" por considerar que la intención del autor es que se reconozca el toponímico.
} 
y antes que el sol, reconociendo el alba, con más furia nos hiera y nos ofenda, haced a la ciudad la primer salva.

(Se dispara el cañonazo de advertencia.)

Decid que defenderse no pretenda, porque la he de ganar a sangre y fuego, que el campo inunde, el edificio encienda.

(Para sí.) El alma traigo de temores llena, ${ }^{113}$ echada juzgo contra mí la suerte ${ }^{114}$ desde que de Lisboa, al salir, sólo imágenes he visto de la muerte. ${ }^{115}$

¿No son el mismo Alá y Dios? ¿Por qué este afán de conquista? "La fe no es cosa de ciencia", me explicaron en la Iglesia. También me han dicho: "Fernando, haz por Dios propia fortuna

sin más armas ni recursos que de la cruz la defensa", y con promesa de riquezas convencí tripulación sólo para dos galeras. ${ }^{116}$

Apenas, pues, al berberisco polo ${ }^{117}$ previnimos pocos esta jornada, cuando de un parasismo ${ }^{118}$ el mismo Apolo, amortajado en nubes, la dorada faz escondió, y el mar sañudo y fiero deshizo con tormentas nuestra armada. Tragó una nao, iqué susto y desconcierto! Y a Tánger llegamos en un solo barco.

\footnotetext{
${ }^{113}$ Parlamento de Don Enrique en el original. Muchas acciones y diálogos correspondientes a otros personajes han sido asimilados a Fernando, tal y como habría hecho Don Antonio en las condiciones del bululú.

${ }^{114}$ Pocos apoyaban la campaña de Fernando, quien requería acreditar méritos para obtener una fortuna que sus otros hermanos ya habían asegurado por el sólo hecho de ser los mayores. Dice Julián Elliot: "La sociedad de la Edad Media privilegiaba a los primogénitos. Abundaban los segundones de buena cuna [como sería el caso de Fernando] que querían ganarse el pan de un modo honorable, lo que en su casta significaba por las armas. No todos tenían la suerte de heredar un señorío ni de obtenerlo en combate o casándose con una dama rica" ("La vida por el honor", en Historia y vida. Agosto 2005. No. 449, año XXXVII. 50.) Fernando fue el octavo hijo de Juan I. "Fernando cedo se mostrou interessado na questão religiosa e, ainda muito jovem, foi ordenado Grão Mestre da Ordem de Avis pelo seu pai. Por ser o irmão mais novo, não tem acesso, como os mais velhos, a tantas riquezas, e intenta pôr-se ao serviço do Papa, do Imperador, ou de outro soberano europeu para ganhar prestígio e prebendas. Por motivação dos irmãos mais velhos acaba por desistir, virando as suas atenções para a luta em Marrocos, da qual lhe poderia vir imensa fortuna." (Dicionário Histórico, Corográfico, Heráldico, Biográfico, Bibliográfico, Numismático e Artístico. 1904-1915. Lisboa: João Romano Torres - Editor. Edição electrónica: Manuel Amaral, 2000-2010.)

115 Nótese el potencial cambio de sentido entre "desde que de Lisboa, al salir, sólo / imágenes he visto de la muerte" y "desde que de Lisboa, al salir solo, / imágenes he visto de la muerte." Valga esto como una pequeña observación crítica a las nuevas propuestas de normativa ortográfica de la RAE en 2011.

${ }^{116}$ Estos últimos once versos intentan una aportación personal a la discusión post-colonial de los valores de conquista territorial de los estados absolutistas del Renacimiento y el Barroco.

117 Berberisco: sinónimo de berebere: oriundo de Berbería (nombre dado entonces a las regiones del $\mathrm{N}$ de África: Argelia, Túnez, Marruecos, a veces también llamados en su conjunto Maghreb.)

118 "Parasismo": paroxismo: "accidente peligroso o casi mortal" (DRAE).
} 
Si miro al mar, mil sombras considero; si al cielo miro, sangre me parece su velo azul; si al aire lisonjero, aves nocturnas son las que me ofrece; si a la tierra, sepulcros representa donde mísero yo caiga y tropiece.

Pues descifrar aquí mi amor intenta la causa del melancólico accidente. ¿Por qué nos has tratado, Dios, así? ${ }^{119}$

(Trata de explicarse el naufragio y se arma de valor.)

Sorbernos una nave una tormenta es decirnos que sobra aquella gente para ganar la empresa a que venimos; vestir púrpura el cielo transparente es gala, no es horror, y si fingimos ${ }^{120}$ monstruos al agua y pájaros al viento, nosotros hasta aquí no los trajimos; pues si ellos aquí están, ¿no es argumento

que a la tierra que habitan inhumanos ${ }^{121}$ pronostican el fin fiero y sangriento?

Esos agüeros viles, miedos vanos, para los moros vienen, que los crean, no para que los duden los cristianos.

Nosotros - pues - lo somos; no se emplean nuestras armas aquí por vanagloria de que en los libros inmortales lean ojos humanos esta gran victoria. ${ }^{122}$ La fe de Dios a engrandecer venimos. Suyo será el honor, suya la gloria. A servirle venimos ${ }^{123}$, no a ofenderle: Cristiano soy; haré como cristiano.

(Ve acercarse a la caballería enemiga.)

Sin embargo, ¿qué es aquesto?

A la falda de ese monte veo una tropa de jinetes, que de la parte de Fez corriendo a esta parte vienen tan veloces, que a la vista aves, no brutos, parecen.

\footnotetext{
${ }^{119}$ Impronta del bululú.

${ }^{120}$ Calderón usa "fingir" como 'simular que hay' o 'hacer como que vemos'.

${ }^{121}$ Inhumanos son los "monstruos" y "aves nocturnas" (seguramente murciélagos). También cabría tomar en cuenta que sólo si se es bautizado como miembro de la comunidad cristiana se consideraría aquí, en este contexto de conflictos religiosos y geopolíticos, como ser humano a una persona.

${ }^{122}$ El libro "inmortal" se llamará, con el tiempo: Chronica dos feitos, vida e morte do Iffante [sic] sancto Dom Fernando que morreo em Feez, de João Alvares, O.A. (1406?-ca 1490).

${ }^{123}$ Calderón reitera "venimos", venir en presente, nunca usa el pasado "vinimos".
} 
El viento no los sustenta, la tierra apenas los siente. Y así la tierra ni el aire sabe si corren o vuelan. ${ }^{124}$

Salgamos a recibirlos, haciendo primero frente todos los arqueros ${ }^{125}$, luego los que caballos tuvieren salgan también a su usanza, con lanzas y con arneses. ${ }^{126}$ (Saca la espada.)

Ea, Fernando, buen principio esta ocasión nos ofrece, no me espantan accidentes del tiempo, ni me espantará el semblante de la muerte. ${ }^{127}$

(Tocan alarma para pelear contra los moros.

Primera Batalla. Los portugueses van ganando, los moros huyen)

A ellos, que ya los moros vencidos la espalda vuelven...

(Mira el campo de batalla.) Llenos de despojos quedan, de caballos y jinetes estos campos... ¡Ah! ¿Quién vive?

(Descubre, persigue, vence e interpela al general moro Muley.)

En la desierta campaña que tumba común parece de cuerpos muertos, si ya no es teatro de la muerte, sólo tú, moro, has quedado porque, rendida, tu gente se retiró, y tu caballo, que mares de sangre vierte envuelto en polvo y espuma que él mismo levanta y pierde, te dejó, para despojo de mi brazo altivo y fuerte, entre los sueltos caballos de los vencidos jinetes. ${ }^{128}$

\footnotetext{
124 "Vuelen" en el original, una rima forzada de Calderón que podría cambiar el sentido de la frase para el espectador contemporáneo.

${ }^{125}$ Calderón propone arcabuceros, pero el arcabuz es un arma de fuego que no se había inventado todavía en la época original en la Batalla de Tánger del Infante Santo (1437).

${ }^{126}$ Se describe a un ejército bastante bien guarnecido. Como se sabe, un ejército medieval regular podía incluir tropas de infantería (lanceros, piqueros, espadachines [otras armas podían ser: alabarda, hacha, maza o mangual]), artillería (arqueros, ballesteros) y caballería (guerreros a caballo con armadura, lanza y espada). Los arneses son las armaduras.

${ }^{127}$ Valentía estoica muy propia para este héroe de Calderón, reconocido lector de Séneca: “Bien sabes que no es forzoso conservar la vida, pues lo importante no es vivir mucho, sino bien vivir. Así es que el sabio vive lo que debe, no lo que puede. Examinará dónde, cómo, con quién, por qué debe vivir; lo que será su vida, no lo que pueda durar." (Cartas a Lucilio. LXX)
} 
(A punto está de decapitar a Muley, pero se contiene.)

¿Qué sientes, pues ya yo creo

que el venir preso no sientes?

"Ganas de morir", respondes,

¿y tu nombre? "Muley", dícesme,

"Muley, general de Fez."129

Comunicado el dolor

se aplaca, si no se vence,

y yo, que soy el que tuve

más parte en este accidente

de la fortuna, también

quiero ser el que consuele

de tus suspiros la causa,

si la causa lo consiente...

(Escucha.)

Te he escuchado y por la dama

que amoroso tú pretendes,

hija doncella de Abdalá,

el rey tirano de Fez,

que por nombre llamas Fénix,

convencido me has. ¡Vete! ${ }^{130}$

Vuélvete, y dile a tu dama

que por su esclavo te ofrece

un portugués caballero.

¡Toma otro rocín, es tarde!...

Generosa acción es dar,

y más la vida: Huye, vé ${ }^{131} \ldots$

El guerrero moro se va. ${ }^{132}$

(Suenan cajas y trompetas.)

Mas, ¿qué trompa es aquesta, que el aire turba y la región molesta?

Y por estotra parte

cajas se escuchan; música de Marte

-dios oscuro de la guerra-

son las dos.

${ }^{128}$ Observamos en esta estrofa un notable ejercicio de encabalgamiento de Calderón, usándolo de hecho en referencia directa con imágenes de caballos y activando la imaginación del espectador para recrear un desolador paisaje post-bélico.

${ }^{129}$ El nombre es desplegado de manera explícita por el bululú para claridad del espectador.

${ }^{130}$ Esta pequeña estrofa es un ejercicio de dramaturgia actoral en el contexto de la estrategia bululú para adaptar el relato dramático original a las condiciones objetivas de representación, conservando la intención poética de su autor. La historia de amor de Fénix y Muley, en conflicto por un compromiso obligado entre Fénix y el rey Tarudante de Marruecos, además de por los celos de Muley (otro moro celoso, como Otelo), es adicional y complementaria a la diégesis esencial de Fernando. Para no omitirla del todo, si bien no es imprescindible, en esta adaptación se le hacen tres breves referencias: una aquí con Muley, otra más adelante en una entrevista entre Fernando y Fénix, y una más al final para liberar a Fénix, presa de los cristianos, a cambio del cuerpo de Fernando, retenido por los moros.

${ }^{131}$ A la valentía se suman aquí la nobleza y generosidad como virtudes en don Fernando. Dice Séneca: "El dolor debe ser vencido por el hombre, y no el hombre por él." (Cartas a Lucilio. LXIII)

${ }^{132}$ Se ha hecho síntesis del diálogo original entre Fernando y el general Muley, tratando de resolverlo como lo haría el actor bululú. 
Aquellos ecos

ejércitos de Fez y Marruecos

son, porque el rey Tarudante de Marruecos

al rey Abdalá de Fez socorre, y arrogante

este rey con gente viene.

En medio cada ejército nos tiene

de modo que, cercados,

somos los sitiadores y sitiados.

Si la espalda volvemos

a uno, mal del otro nos podremos

defender, pues por una y otra parte

nos deslumbran relámpagos de Marte.

¿Qué haremos, pues, de confusiones llenos?... ${ }^{133}$

(De la situación desesperada toma nuevo valor.)

¿Qué? Morir como buenos,

con ánimos constantes.

¿No soy yo un maestre de Avis, un infante?

Como si no bastara ser portugués

en particular, para no haber visto

la cara al miedo. Pues Avis y Cristo ${ }^{134}$

a voces repitamos,

y por la fe muramos,

pues a morir venimos.

¡Avis y Cristo, Avis y Cristo!

(Combate. Segunda Batalla. Se observa que ahora los portugueses van perdiendo.)

Mala salida a tierra dispusimos.

Ya no es tiempo de medios,

a los brazos apelen los remedios,

pues uno y otro ejército nos cierra

en medio. ¡Avis y Cristo!

¡Guerra, guerra!

(Pelea. Cae herido.

Lo aprehenden. Escucha que lo interrogan.)

${ }^{133}$ Estas últimas dos estrofas correspondían a Don Enrique en el original. Aquí las hemos incorporado al parlamento de Fernando siguiendo la estrategia del bululú. El personaje toma nuevas fuerzas a partir de sus propias angustias.

${ }_{134}$ Divisa que proclama la supremacía de la religión católica y de la Casa de Avis gobernante, a la que pertenece Fernando. Se conoce que La Casa de Avis fue la segunda dinastía reinante en Portugal, fundada por Juan I en 1385 (padre de Fernando). Por otro lado, la Orden de Avis, a la que también pertenece el Infante Fernando, y de la que es dirigente con el grado superior de Maestre, fue una orden militar y religiosa, fundada en Coimbra (Portugal) en el siglo XII. Su escudo de armas es una cruz mariana (con los brazos en forma de letras "M", como en la Orden de Sant Jordi.)

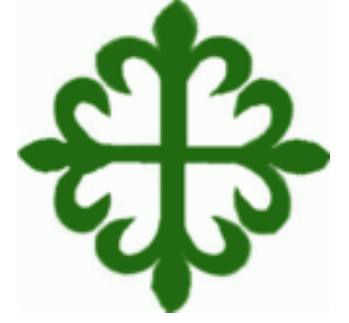


(A su vencedor.) Un caballero soy, saber no esperes más de mí. Dame muerte.

(Se abre el jubón por el pecho, que muestra un Crucifijo de Avis ${ }^{135}$, emblema de su estirpe.)

(Para sí.) ¡Ea, muéstrese agora el heredado brío!

(Escucha al rival que le ha vencido: el REY ABDALÁ de Fez.)

¿Que este preso te basta

por ahora por victoria? (Escucha.)

Si mi prisión o muerte

con tal sentencia decretó la suerte y

es mi condición que Enrique,

el Príncipe Navegante,

mi hermano, pueda ser libre

para ir a Portugal a

negociar mi libertad... (Escucha.)

Doy la espada yo, Fernando,

... ¡al rey Abdalá de Fez! ${ }^{136}$ (Entrega su espada al REY de Fez.)

Sólo a un rey la rindiera,

que desesperación negarla fuera.

En la suerte importuna

éstos son los sucesos de fortuna.

Enrique, hermano, preso quedo.

$\mathrm{Ni}$ al mal ni a la fortuna tengo miedo... (Medita.)

Dirásle a nuestro otro hermano,

el rey Duarte en Portugal,

que haga aquí como príncipe cristiano

en la desdicha mía.

Dirásle al rey... Mas no le digas nada

sino con gran silencio, en miedo vano

estas lágrimas lleva al rey mi hermano.

(Se despide con pesar.

Vanse los suyos mientras él queda en prenda con otros cautivos. $)^{137}$

El alma

queda en lastimosa calma,

viendo cómo os alejáis

de mis manos. ¡Quien pudiera

socorrernos! ¡Qué dolor!

Duéleme nuestra fortuna ${ }^{138}$

\footnotetext{
135 Ibídem.

${ }^{136}$ Se han fundido en estos fragmentos parlamentos de Don Juan de Silva (noble y oficial de tropa en el original de 1629, no confundir con Juan de Portugal), del rey de Fez, de Fernando y del bululú, siguiendo su estrategia de colaboración en los términos del teatro profesional del Barroco español. Asimismo, se presentan los nombres extendidos de Enrique y Abdalá (este último sin nombre en las versiones de 1629, 1636 y 1640.)

137 "A campanha revelou-se um desastre e, para evitar a chacina total dos portugueses, estabelece-se uma rendição pela qual as forças portuguesas se retiram, deixando o infante como penhor da devolução de Ceuta (conquistada pelos portugueses em 1415). No entanto, o Infante pareceu ter pressentido o seu destino, pois ao despedir-se do seu irmão, o Infante D. Henrique, lhe terá dito 'Rogai por mim a ElRei, que é a última vez que nos veremos!" (Dicionário Histórico, Corográfico, Heráldico, Biográfico, Bibliográfico, Numismático e Artístico. 1904-1915. Lisboa: João Romano Torres - Editor. Edição electrónica: Manuel Amaral, 2000-2010.)
} 
y en la desdicha importuna

aprendo a ser infelice.

(Una melodía en flauta representa el paso del tiempo.)

Naciendo infante, he llegado

a ser esclavo; y así

temo venir desde aquí

a más miserable estado;

que si ya en aqueste ${ }^{139}$ vivo,

mucha más distancia trae

de infante a cautivo que hay

de cautivo a más cautivo.

... Un día llama a otro día,

y así llama y encadena

llanto a llanto y pena a pena.

(Don ANTONIO representa el paso del tiempo en el cuerpo de don FERNANDO

y luego alterna entre él y don ENRIQUE.)

(A otros cautivos) ¿Cuántos meses han pasado?

(Escucha que han transcurrido varios meses. Asiente.)

Amigos, su compañía

hace nuestra esclavitud

dichosa en la compartida

prisión tirana de Fez. ${ }^{140}$

(Divisa un barco en el horizonte del mar.)

Mas, ¿qué veo en el horizonte?

¡Salgan todos a la orilla

del mar, y verán en ella

el más hermoso animal

que añadió naturaleza

al artificio; porque

una cristiana galera

llega al puerto, tan hermosa, ...

aunque toda oscura y negra,

que al verla se duda cómo

es alegre su tristeza! ${ }^{141}$

(Sube a una torre para ver mejor.)

${ }^{138}$ El bululú ha cambiado del original la $3^{\mathrm{a}}$ por la $1^{\mathrm{a}}$ persona gramatical del plural.

${ }^{139}$ Aqueste. Los demostrativos se refuerzan en latín con el adverbio demostrativo acce y en latín vulgar con el demostrativo ya reforzado eccum, de donde eccu $(m)$-iste, aqueste. (El príncipe constante. Panamá: Empresa Latinoamericana de Comercio Exterior, 1977. 90.)

${ }^{140}$ Ejercicio de dramaturgia bululú para dejar en claro el paso del tiempo y la cohabitación de Fernando con otros prisioneros de guerra.

${ }^{141}$ Otro expresivo encabalgamiento calderoniano. (El primero que destacamos en esta obra es con el que se inicia la Primera Batalla de Tánger.) 
Las armas de Portugal ${ }^{142}$

vienen por remate de ella; que como tienen cautivos a sus hijos, tristes señas visten por su esclavitud, y a darles libertad llegan, diciendo su sentimiento. ${ }^{143}$

(Asoma y mira mejor.) Temo, amigos, no sea ésa

de su luto la razón,

que si a librarnos vinieran,

en fe de la libertad

fueran alegres las muestras...

(Observa.) ¡Mi hermano el príncipe Enrique!...

Desembarcado ya ha...

Saluda a Abdalá y a su corte...

Y agora viene conmigo. (Baja a recibir a su hermano.) ${ }^{144}$

(Ve que Enrique viste de negro.) Enrique, hermano,

¿qué traje es éste? Mas cesa;

harto me han dicho tus ojos,

nada me diga tu lengua...

No llores, que si es decirme

que es mi esclavitud eterna,

eso es lo que más deseo;

albricias pedir pudieras,

y en vez de dolor y luto

vestir galas y hacer fiestas...

¿Cómo está el rey don Duarte,

nuestro hermano y señor?

Porque como él salud tenga,

nada siento... ¿Aún no respondes?

(Don ANTONIO se viste de Don ENRIQUE con un manto negro.)

\section{ENRIQUE: ¡Ay, Fernando!}

${ }^{142}$ Las Quinas son las Armas de Portugal: cinco escudos azules en cruz, que llevan cada uno cinco monedas en aspa. Aparecen en la bandera portuguesa y en el escudo personal de Fernando (este último con el lema: "El bien me place.")
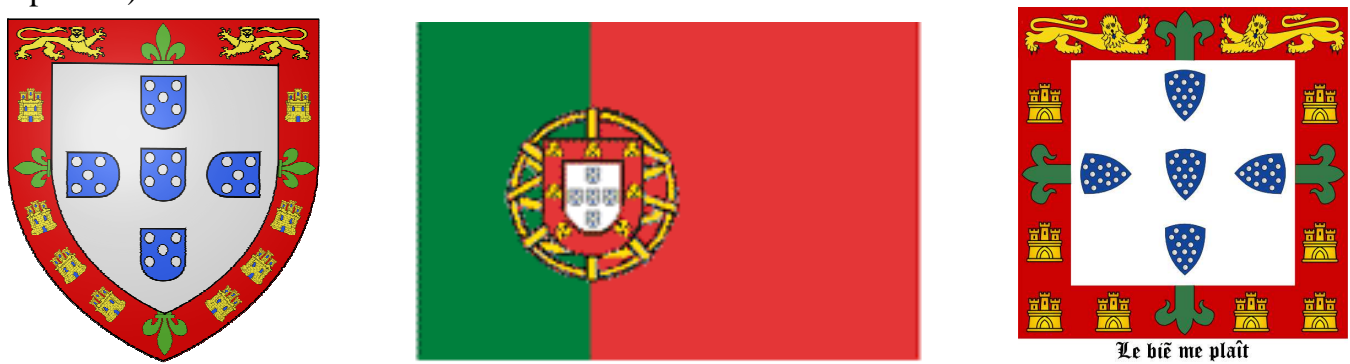

\footnotetext{
${ }^{143}$ Estos parlamentos corresponden a don Juan de Silva en el original de 1629, cautivo junto a don Fernando.
}

${ }^{144}$ Versos de dramaturgia bululú. 
Si repetidas las penas

se sienten dos veces, quiero

que sólo una vez las sientas.

(Al rey de Fez.) Tú, óyeme, rey Abdalá;

que aunque esta montaña sea

rústico palacio, aquí

te pido me des audiencia,

a un preso la libertad,

y atención justa a estas nuevas.

Rota y deshecha la armada, que fue con vana soberbia pesadumbre de las ondas, dejando en África presa la persona del infante,

a Lisboa di la vuelta.

Desde el punto que Duarte ${ }^{145}$

oyó tan trágicas nuevas,

de una tristeza cubrió

el corazón, de manera

que pasando a ser letargo

la melancolía primera,...

muriendo desmintió a cuantos

dicen que no matan penas.

Murió el rey, que esté en el cielo. ${ }^{146}$ (Saca un pliego.)

En su testamento

el rey mi señor ordena

que luego por la persona

del infante se dé a Ceuta,

la estratégica ciudad,

como reclama Abdalá. ${ }^{147}$

Y así yo, con los poderes de su hijo

don Alfonso, ${ }^{148}$ que es quien le hereda,

porque sólo este lucero

supliera del sol la ausencia,

vengo a entregar la ciudad; (sonríe esperanzado)

y pues... ¿qué piensas, Fernando? ${ }^{149}$

\footnotetext{
${ }^{145}$ En la obra el rey de Portugal y hermano de Fernando y Enrique. Calderón respeta "Duarte", en portugués, por "Eduardo", nombre en castellano del monarca histórico.

146 "Don Duarte murió víctima de la peste en 1438, dejando escrito en su testamento que se rescatara a don Fernando con la entrega de Ceuta. Las negociaciones no tuvieron éxito debido a las exigencias de los moros." (Valbuena Briones: 114.) Se sabe también que las Cortes de Leira se negaron a rescatar a Fernando a cambio del estratégico puerto, y que fue hasta entonces que el príncipe reconoció y aceptó su destino.

${ }^{147}$ Verso introducido para obviar las escenas donde el rey de Fez presenta su demanda.

${ }^{148}$ Alfonso V, hijo de Duarte y por lo tanto sobrino de Fernando. Alfonso tiene a su vez un hermano de nombre Fernando, que no aparece en Calderón.

${ }^{149}$ Pregunta de transición entre personajes, propuesta por el bululú.
} 
(De súbito, don Antonio deja de representar a don Enrique

y ahora hace de don Fernando.)

FERNANDO: (Interrumpe a Don Enrique)... No prosigas, cesa.

Cesa, Enrique, porque son

palabras indignas ésas.

Mi hermano Duarte, en el cielo, si en su testamento deja

esa cláusula, no es

para que se cumpla y lea,

sino para mostrar sólo

que mi libertad desea

y ésa se busque por otros

medios y otras conveniencias,

o apacibles o crüeles;

porque decir "Dese a Ceuta"

es decir "Hasta eso haced

prodigiosas diligencias."

Que a un rey católico y justo, ¿cómo fuera, cómo fuera

posible entregar a un moro

una ciudad que le cuesta

su sangre, pues fue el primero

que con sólo una rodela ${ }^{150}$

y una espada enarboló

Las Quinas ${ }^{151}$ en sus almenas?

¿Fuera bien que sus capillas

a ser establos vinieran,

sus altares a pesebres?

Los católicos que habitan

con sus familias y haciendas

hoy, quizá prevaricarán

en la fe, por no perderlas.

¿En mísero cautiverio

fuera bueno que murieran

hoy tantas vidas, por una

que no importa que se pierda?

¿Quién soy yo? ¿Soy más que un hombre?

(Se quita el crucifijo insignia de su real estirpe.)

Si es número que acrecienta

el ser infante, ya soy

un cautivo, de nobleza

no es capaz el que es esclavo;

yo lo soy, luego ya yerra

\footnotetext{
${ }^{150}$ Escudo redondo y pequeño.

${ }^{151}$ Escudo de armas de Portugal. Vid supra.
} 
el que infante me llamare.

Si no lo soy,

si ya no soy un infante,

¿quién ordena

que la vida de un esclavo

en tanto precio se venda?...

Morir es perder el ser, yo le perdí en una guerra; perdí el ser, luego morí. ${ }^{152}$

... ¡Morí!, luego ya no es cuerda

hazaña que por un muerto

hoy tantos vivos perezcan.

Y así estos vanos poderes,

hoy divididos en piezas,...

... serán átomos del sol,

\section{(Rompe el pliego.)}

serán del fuego centellas (arroja los pedazos al viento)

porque aún no quede una letra

que informe al mundo que tuvo

la lusitana nobleza

este intento. Abdalá, soy

tu esclavo, dispón, ordena

de mi libertad, no quiero

ni es posible que la tenga.

Enrique, vuelve a tu patria,

di a nuestro sobrino, el nuevo rey

Alfonso, que en África me dejas

enterrado, que mi vida

yo haré que muerte parezca.

Cristianos, Fernando es muerto;

moros, un esclavo os queda;

cautivos, un compañero

hoy se añade a vuestras penas.

(Antonio se despoja del vestuario. Se ve más cansado que al principio.)

ANTONIO: ¡Pedro Calderón, qué gran historia escogiste para mi bautizo como actor! ¿Cuánto mejor será cuando por fin la termines?... Tal vez quieras escuchar mi opinión mientras descanso un poco las piernas. ¡Y yo que pensé que no sería gran cosa caminar desde Madrid hasta Sant Jordi! (Toma la espada. Diserta consigo mismo.) El arma típica del soldado heroico es la espada, lo cual hace de tu obra

\footnotetext{
152 Dice Séneca: "Nuestro término está firme allí donde lo fijó el hado inexorable, pero ninguno de nosotros sabe a qué distancia se encuentra. Dispongamos, pues, de nuestro ánimo como si ya hubiésemos llegado a nuestro fin. No aplacemos nada: saldemos cada día nuestras cuentas con la vida. El mayor defecto de la vida está en que siempre es incompleta, porque siempre dejamos algo aplazado. A quien sabe dar cada día a su vida la última mano, no le falta tiempo." (Séneca. Cartas a Lucilio. CI.)
} 
una tragedia histórica o... quizá una comedia de capa y espada. Sin embargo, una fe llevada al sacrificio como la del Infante Fernando sólo se ve en la vida de los santos, lo que vuelve la obra casi un auto sacramental. A todo esto, por cierto, ¿cuál es el armamento del actor? Ah, ¿quién iba a pensar que tan lejos de mis compañeros, del tablao $^{153}$ y de la tramoya fuera a descubrir, en la humildad del solitario oficio del actor bululú, la esencia del arte teatral, persiguiendo, como explica el maestro Agustín de Rojas Villandrando, mi "estrella de pueblo en pueblo, ganando un pedazo de pan aquí y una escudilla de caldo allá", casi siempre sin hallar más remedio que la sonrisa de un anciano espectador? ${ }^{154}$ Cuánto consuelo me trajo la mirada de aquel barbero a quien le recité unos fragmentos de cierta novela de Don Miguel de Cervantes: "En un lugar de la Mancha, de cuyo nombre no quiero acordarme, no ha mucho tiempo que vivía un hidalgo de los de lanza en astillero, adarga antigua, rocín flaco y galgo corredor." (Aplaude.) "Bravo, Antonio, bravo!" Su sencillo aplauso me satisfizo más que una bolsa llena con oro. Y es que como actor he podido, más que sólo conocer de poetas y de letras, el vivir en mis labios y en mi piel sus versos. ${ }^{155}$ Según dice Don Félix Lope de Vega, éstas son las armas del actor: "Acción, memoria, lengua y osadía." 156 (Revisa el manuscrito de Calderón.) El manuscrito de Pedro Calderón dice que después de haber protegido a Fernando como prisionero de guerra con algunos pocos privilegios especiales, al no obtener Ceuta el rey Abdalá de Fez entró en cólera y comenzó a tratar al príncipe peor que a cualquiera de los otros cautivos, haciéndole lavar las mazmorras y los baños, y apenas dándole algo de comer... Y yo que me quejo y me mareo por un solo día de ayuno. ¡Sigamos adelante! Haciendo agora ${ }^{157}$ el diálogo del rey Abdalá de Fez con el Infante Fernando podré medir mi calibre como actor y quizá encontrarme a mí mismo.

\section{(Don ANTONIO ahora hace del REY ABDALÁ de Fez.)}

REY ABDALÁ: Desagradecido, ingrato

a las glorias y grandezas

de mi reino, ¿cómo así

hoy me quitas, hoy me niegas

lo que más he deseado?

Mi ciudad de Ceuta, la meridional de las columnas de Hércules. ${ }^{158}$

153 Tablao: Contracción vulgar de "Tablado", en referencia al escenario de madera de los corrales de comedias.

${ }^{154}$ Recreación de la descripción del bululú en Rojas Villandrando (op. Cit.)

${ }^{155}$ Se plantea que la experiencia actoral es, sincrónicamente: literaria, física y emocional, lo cual constituye la singularidad del análisis filológico actoral.

156 (Lope de Vega. El guante de doña Blanca.) Comparando hoy día testimonios, críticas y diversos estudios podemos afirmar que las cualidades del actor español barroco eran: buena memoria, voz (volumen y dicción), desenvoltura (osadía), acción (entendida como movimiento físico tanto como emocional) y presencia (buen físico, talle y donaire), es decir, poco o nada diferentes a lo mínimo deseable hasta para un actor contemporáneo. El Diccionario de autoridades de 1726 determina además, para ser calificado de "buen actor", el representar "con primor".

157 Agora. Del latín hac hora, forma arcaica, por ahora. (El príncipe constante. Panamá: Empresa Latinoamericana de Comercio Exterior, 1977. 81.)

${ }^{158}$ Estos dos versos insertos por el bululú explicitan la naturaleza estratégica del puerto de Ceuta. 
Mas si en mi reino gobiernas

más que en el tuyo, ¿qué mucho

que la esclavitud no sientas?

Pero ya que esclavo mío

te nombras y te confiesas,

como a esclavo he de tratarte.

Todos los cautivos vean

que ya, como vil esclavo,

los pies agora me besas. (Espera a ser besado en los pies.)

Mi esclavo eres.

Siendo esclavo, tú no puedes

tener títulos ni rentas.

Hoy Ceuta está en tu poder;

si cautivo te confiesas,

si me confiesas por dueño,

por Alá que es el único Dios,

y por Mahoma, su profeta, ${ }^{159}$

¿por qué no me das a Ceuta? (Escucha.)

¡Dices que es de Dios, no tuya! (Piensa un instante.)

¿No es precepto de obediencia

obedecer al señor?

Pues yo te mando con ella

¡que la entregues o müere! (Escucha una nueva negativa.)

Pues ya que no te doblegas,

vive muriendo; que yo

rigor tengo... (Azota a Fernando.)

Despojadlo de sus ropas

y cargadlo de cadenas.

Que lave baños, mazmorras...

FERNANDO: Cruel Abdalá: ${ }^{160}$ En lo justo

dice el cielo que obedezca

el esclavo a su señor;

pero si el señor dijera

a su esclavo que pecara,

obligación no tuviera

de obedecerle; porque

quien peca mandando, peca. (Ve que el rey se dispone a irse.)

¿Tan pronto ya te vas? ¡Óyeme!

Nunca será tuya Ceuta.

Antes, tirano Abdalá,

conocerás mi paciencia,

porque ésta en mí será eterna. ${ }^{161}$

\footnotetext{
${ }^{159}$ Este par de líneas aportadas por el bululú colocan los argumentos del rey de Fez en el contexto del choque de civilizaciones que significaran las Guerras de Reconquista.

${ }^{160}$ Frase de transición del bululú.
} 
(Vase el REY ABDALÁ. Se hace de noche en Fez.

El infante FERNANDO es vestido de cautivo y cargado con cadenas.)

Cae una noche estrellada.

Triste estoy, muy hambriento, enfermo y turbado...

ANTONIO: (Delira.) Fuerza, Fernando, que sois un caballero de Avis. ${ }^{162}$

FERNANDO: (Delira a su vez.) Constancia, Antonio, que eres un actor de Madrid.

(Escucha.) Abdalá mandó que asista

en aqueste jardín, y no resista

mi obediencia a su ley... ${ }^{163}$

¡Mayor que su rigor sea mi paciencia!

(Cava en un jardín pleno de flores amarillas, blancas y rojas. $)^{164}$

ANTONIO: Consolad los rigores, Fernando, que hay que regar aquestas flores.

(Toma un cubo de agua y canta.)

FERNANDO: "Éstas, que fueron pompa y alegría

despertando al albor de la mañana,

a la tarde serán ya sombra vana,

durmiendo en brazos de la noche fría.

Este matiz, que al cielo desafía,

iris listado de oro, nieve y grana,

será escarmiento de la vida humana.

¡Tanto se pierde en término de un día!

A florecer las rosas madrugaron,

y para envejecerse florecieron:

Cuna y sepulcro en un botón hallaron.

Tales los hombres sus fortunas vieron:

En un día nacieron y expiraron; ${ }^{165}$

que pasados los siglos, horas fueron." 166

(Tropieza.) Mortales, no os espante

ver un Maestre de Avis, ver un infante ${ }^{167}$

${ }^{161}$ La paráfrasis elíptica del diálogo es alternada en esta escena con dramaturgia del bululú.

${ }^{162}$ El cansancio, el hambre y la sed son aquí el vaso comunicante para poner en discusión las fronteras entre ficción y realidad, o bien, entre dos niveles ficcionales.

${ }^{163}$ El original es la instrucción del personaje Celín (o Zelín) a don Fernando: "y no resistas / su ley a tu obediencia.".

${ }^{164}$ Los colores corresponden a los de las rosas de "oro, nieve y grana" que se mencionarán en el soneto que sigue.

165 "Espiraron" (con "s") en el original. La actualización pretende que no se pierda la intentio semántica.

166 Este soneto es un claro equivalente de las pinturas llamadas vanitas, género de naturalezas muertas, popular en el Barroco, donde se relativizaban las ambiciones mundanas como la riqueza, el poder y la belleza. Va más adelante en el texto original.

${ }^{167}$ Don Fernando es Maestre, o sea, el caballero de mayor rango en la orden militar y religiosa de Avis y, siendo príncipe de la casa real, Infante también. 
en tan mísera afrenta;

que el tiempo estas miserias representa.

ANTONIO: (Aparte) ¡Fernando, Majestad,... quisiera ocultarme y encubrirme!

FERNANDO: (A los demás cautivos) No hagáis ceremonias ya conmigo, Antonio. ¿Qué alteza

ha de tener quien vive en tal bajeza?

Ved que yo humilde vivo,

y soy entre vosotros un cautivo.

Ninguno ya me trate

sino como a su igual.

(Toma un azafate y atiende.)

Al jardín sale Fénix, la señora

amada del libre Muley,

hija doncella del rey, ${ }^{168}$

y manda que matices y colores

borden un azafate ${ }^{169}$ de sus flores.

Yo llevárselas quiero,

que en cuanto sea servir seré el primero.

Ea, vamos a cogellas.

(Vase el infante FERNANDO y sale Don ANTONIO, cada vez más fatigado.)

ANTONIO: El ayuno y el humo de las velas ya me están haciendo delirar. Pedro, vaya que tu obra es bastante complicada y agotadora. ¿Podrás acabarla algún día? (Revisando el manuscrito de la obra.) Aquí dice que Fénix era la hija del rey Abdalá de Fez, enamorada del general Muley pero obligada por su padre a casarse con el rey Tarudante de Marruecos. ${ }^{170}$ En un sueño terrible, ella profetiza que aunque al principio Ceuta es la moneda de cambio exigida por los moros para recuperar a Fernando, es ella quien terminará siendo el precio del rescate del infante portugués, o de su cuerpo muerto. Ambos, Fénix y Fernando, se encuentran en un momento en el cual Fernando está ya muy tullido, causando incluso el asombro de quienquiera que lo mira... Hagamos salir a escena a Fénix. " „Apurad, cielos, pretendo!"171 (Comienza a improvisar su disfraz con lo que encuentra en su arca, pero vacila.) Sin embargo... ¿a qué le tengo miedo?... ¡Ah! Las leyes del decoro me prohíben interpretar, siendo yo varón, a una mujer. Sólo en Inglaterra, bajo otros usos y costumbres, los hombres podemos representarlas. ${ }^{172}$ Claro que hay excepciones, pero en este lugar... ¿Cómo debo

\footnotetext{
${ }^{168}$ Una introducción bululú para presentar a Fénix.

${ }^{169}$ Azafate: Canastillo de mimbre con borde de poca altura.

${ }^{170}$ Ya antes mencionamos que Calderón separa como dos los reinos de Fez y Marruecos, aunque tanto Fez, como Ceuta y Tánger son ciudades ubicables en la misma geografía marroquí.

${ }^{171}$ Texto tomado de La vida es sueño, de Calderón. Aquí la hemos propuesto como idiosincrásica de don Antonio, jugando con la idea de que hubiera sido este actor quien se la inspirara al dramaturgo.

${ }^{172}$ El travestismo estaba expresamente prohibido en disposiciones como el Reglamento de teatros de 1615 (Oehrlein. 162). Sin embargo los escritores hacían divertidas excepciones, como por ejemplo en la Nueva España donde la monja Sor Juana Inés de la Cruz, Juana de Asbaje, se permitió la licencia de que un personaje varón se disfrazara de mujer en la comedia Los empeños de una casa. También Tirso
} 
entonces proceder para hacer el papel de la doncella Fénix sin profanar esta santa ermita? No debería preocuparme tanto, pues nadie me ve sino... (al Cielo) ¿No acaso eres tú mi divino espectador? ¿Castigo no me darías si transgredo tu mandato?... Aunque, ¿cuáles son tus designios y quién puede decir verdaderamente que los conoce? ${ }^{173}$ Habrá que averiguarlos. (Contempla la imagen del fondo de "Sant Jordi y el dragón".) El monstruo al que temo sólo habita en mi interior. Un buen actor ha de ser capaz de tomar cualquier personaje y domarlo con maestría, fundirse con él en sudor y lágrimas -fundirse mas no confundirse- para después soltarlo más libre y poderoso, pero también para hacerse él mismo más sabio... "Acción, memoria, lengua, osadía..." ¿Qué falta?... Hace falta la imaginación para crear siempre como nueva la vida del personaje en el escenario. ${ }^{174}$ ¿Y ya? ¿Y cómo imaginar al personaje si no lo siento? ¡Corazón! ¡Corazón es lo que he de sumar también a mis armas! ${ }^{175} \mathrm{Si}$ Dios quiere que sea yo actor o no, yo mismo tendré que descubrirlo, sea él mi juez, mi abogado o mi verdugo.

\section{(Sale FÉNIX interpretada por Don ANTONIO.)}

FÉNIX: Fénix soy, hija del tirano de Fez. ${ }^{176}$

Flores he pedido que me manden.

Sus colores deseé

para que me divirtiesen

en mis graves melancolías.

¿De pesadillas sufrí?

¡No fue sueño lo que vi, que fueron desdichas mías! ${ }^{177}$

Soñé que por un cadáver

mi honor era comprado. ${ }^{178}$

Cuando sueña un desdichado

que es dueño de algún tesoro,

ni dudo, ni ignoro,

que entonces es bien soñado;

mas si a soñar ha llegado

\footnotetext{
de Molina, en Don Gil de las Calzas Verdes, se permite introducir a una dama disfrazada de varón. Por el contrario, en Inglaterra las mujeres tuvieron prohibida la actuación teatral hasta el siglo XVIII, por lo cual los varones debían representar los papeles femeninos.

${ }^{173}$ Vale la pena recordar que fue en aquel tiempo contrarreformista cuando la Inquisición quemó a Giordano Bruno por sostener su panteísmo y ordenó también mostrar el menú de instrumentos punitivos a Galileo Galilei para que se desistiera de publicar sus pruebas de apoyo al heliocentrismo copernicano y sobre el movimiento terrestre.

${ }^{174}$ Constantin Stanislavski sistematizará a principios del siglo XX lo que muchos actores siempre habían intuido: que el arma más importante del actor como artista es su imaginación, misma que le permite crear las emociones del personaje como si las situaciones ficticias del drama fueran las de su propia vida. (Un actor se prepara, La construcción del personaje.)

175 "El actor es como el atleta físico, pero con una sorprendente diferencia: su organismo afectivo es análogo, paralelo al organismo del atleta, su doble en verdad, aunque no actúe en el mismo plano. El actor es un atleta del corazón." (Antonin Artaud. El teatro y su doble, 147.)

${ }^{176}$ Frase de presentación del personaje por el bululú.

${ }^{177}$ En la obra original, Fénix predice en sueños cómo va a ser intercambiada por el cuerpo de don Fernando.

${ }^{178}$ Dos versos aportados por el bululú.
} 
en fortuna tan incierta

que desdicha le concierta

y aquello sus ojos ven,

pues soñando el mal y el bien,

halla el mal cuando despierta.

Piedad no espero, ¡ay de mí!, porque mi mal será cierto.

Ya mis desdichas creí.

¡Precio de un muerto! ¿Quién vio

tal pena? No hay gusto, no.

¡Ay, infelice mujer!

¿Será profético el sueño?

¿Que al fin de un muerto he de ser?

¿Quién será este muerto?

¿Acaso mi amado Muley? ${ }^{179}$ (Viendo a don FERNANDO con las flores.)

¡Ay, cielos! ¿Qué es lo que veo?

(A Fernando.) ¿No eres Fernando acaso, el infante portugués? (Escucha.)

¿Quién te puso así y aquí? (Escucha otra vez.)

Ah. La ley de los esclavos

hecha por mi padre el rey.

Asombro y horror me has dado,

ni oírte ni verte quiero;

sé el desdichado primero

de quien huyó un desdichado.

(Está por partir pero regresa.)

¿Y las flores? Si has hallado

jeroglíficos en ellas,

deshacellas y rompellas,

sólo sabrán mis rigores. (Escucha.)

La culpa es de las flores por

parecerse a las estrellas.

Ya no las quiero. Ninguna

estimo en su rosicler. ${ }^{180}$ (Escucha.)

¿Cómo? Nace la mujer

sujeta a muerte y fortuna;

y en esa estrella importuna

tasada mi vida vi.

Flores con estrellas. Sí. (Escucha.)

Aunque sus rigores lloro,

179 Esta última pregunta es una inserción del bululú para relacionar a los ojos del espectador ambos personajes: Fénix con Muley (el general liberado por Fernando en la Primera Batalla de la obra). Algunos piensan que la anécdota de estos amores pudo ser una colaboración de Rojas Zorrilla para dejar una doble acción en el conjunto de la obra. "La crítica del siglo XVIII consideró esta doble acción dramática como un defecto en la literatura del Siglo de Oro y, especialmente, en Calderón” (El príncipe constante. Panamá: Empresa Latinoamericana de Comercio Exterior, 1977. 64.)

${ }^{180}$ Rosicler: Color rosado de la aurora. 
también de ellas aprendo que vivir sin amar no es justicia, que es locura, egoísta vanidad, soberbia contranatura, por eso a Muley de amar lo yo no me arrepiento. ${ }^{181}$ (Medita contemplando las estrellas.) Esta reflexión escucha:

"De esos rasgos de luz, esas centellas que cobran con amagos superiores alimentos del sol en resplandores, aquello viven que se duele de ellas.

Flores nocturnas son; aunque tan bellas, efímeras padecen sus ardores; pues si un día es el siglo de las flores, una noche es la edad de las estrellas.

De esa, pues, primavera fugitiva ya nuestro mal, ya nuestro bien se infiere. Registro es nuestro, o muera el sol o viva.

¿Qué duración habrá que el hombre espere, o qué mudanza habrá, que no reciba de astro que cada noche nace y muere?"182 En conclusión, don Fernando, mi amigo, para casos de amor y de destino escuchar las estrellas o a las flores para bien o por mal vale lo mismo. Yo ya me voy. ${ }^{183}$

(Fénix unge con un beso al enfermo Fernando.)

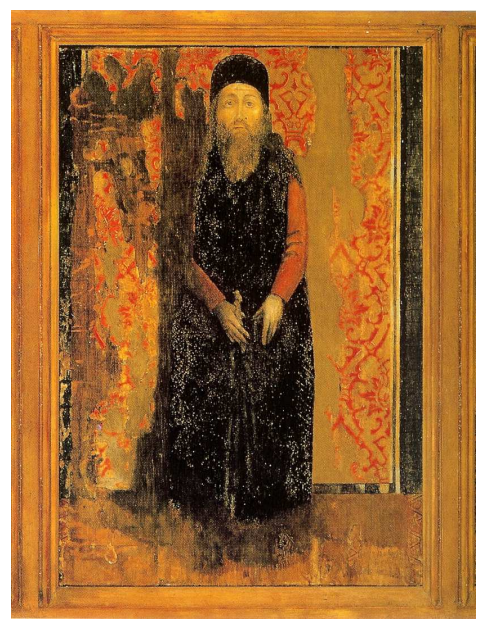

(Retablo O Infante Santo cautivo. Capilla Real en el Monasterio de Batalha, Portugal.)

\footnotetext{
${ }^{181}$ Los versos de Calderón se entrelazan con la dramaturgia explicativa del bululú.

${ }^{182}$ En el soneto de Fénix lo efímero del perfume y el color de las flores es comparado con la fugacidad de la luz de las estrellas. Se trata de otro vanitas poético, equivalente a las pinturas del Barroco.

${ }^{183}$ Versos de transición del bululú.
} 
FERNANDO: Sí aconsejas y es más: yo

igual viva por mi amor.

Que amando a Dios y a mi patria

no tema yo morir, $\mathrm{y}$

así se pueda decir que,

aunque el destino fue breve,

por mi Dios y por mi ley

fui: un Príncipe Constante

en la esclavitud de Fez.

No temas, doncella Fénix, vete sin perder tu fe,

que tus sueños sólo anuncian

que pronto has de estar con Muley. ${ }^{184}$

(Vase FÉNIX. Alborea en Fez.

Se sienta el infante don FERNANDO en una estera.)

Ya se va Fénix, la dama, y

llega el nuevo amanecer. ${ }^{185}$

Pondreme en aquesta parte,

para que goce mejor

la luz que el cielo reparte. (Contempla el amanecer.)

¡Oh inmenso, oh dulce Señor,

qué de gracias debo darte!

Cuando como yo se veía

$\mathrm{Job}^{186}$, el día maldecía;

mas era por el pecado

en que había sido engendrado;

pero yo bendigo el día

por la gracia que nos da

Dios en él; pues claro está

que cada hermoso arrebol

y cada rayo del sol

lengua de fuego será

con que le alabe y bendiga. ${ }^{187}$ (Siente un dolor repentino.)

Hombres, doleos de mí, que una fiera de otra fiera

\footnotetext{
${ }^{184}$ Los versos de Calderón se vuelven a entrelazar con una dramaturgia bululú que evoca el otro título de esta obra: El esclavo por su patria. Fernando asume la vocación de mártir como su ministerio personal.

${ }^{185}$ Estos dos versos son aportación del bululú.

${ }^{186}$ Patriarca bíblico célebre por su piedad y resignación. Obtuvo Satanás del Todopoderoso la autorización para poner a prueba la virtud de Job, y éste se vio pronto rodeado de los mayores sufrimientos, mismos que soportó con paciencia.

${ }^{187}$ El senequismo propio del Barroco y de Calderón hace de la enorme capacidad de sufrimiento la más grande virtud de don Fernando. Su extrema paciencia llevada hasta la muerte da título y sentido a la obra. El filósofo escribió: "Vivamos, pues, con todo el ánimo, y, puesto aparte lo que nos distrae, esforcémonos en una sola cosa: que no tengamos que comprender la rapidez del tiempo infatigable cuando ya nos haya abandonado. Que cada primer día agrade como si fuese el mejor y que se haga nuestro. Hay que tomar posesión de lo que se nos escapa." (Séneca. Cartas a Lucilio. CVIII.)
} 
aun más se compadece.

Ni infante ni maestre ya soy, el cadáver suyo sí; ${ }^{188}$

y pues ya en la tierra estoy, aunque infante y maestre fui, no es ése mi nombre hoy. (Ve que llega el rey Abdalá de Fez.)

Aquí viene mi custodio

el rey Abdalá de Fez. ${ }^{189}$

(Al rey Abdalá.) Agora, aunque me levante

de la tierra, iré arrastrando

a besar tu pie.

Esta obediencia, más

que humildad o valor,

es mostrar

cuánto debe respetar

el esclavo a su señor;

y pues que tu esclavo soy, y estoy en presencia tuya, esta vez tengo que hablarte. Mi rey y señor, escucha: ${ }^{190}$

Rey te llamé y, aunque seas

de otra ley, es tan augusta

de los reyes la deidad,

tan fuerte y tan absoluta, que engendra ánimo piadoso, y así es forzoso que acudas a la sangre generosa

con piedad y con cordura, porque el ser rey no te disculpa de otra ley, que la crueldad en cualquiera ley es una.

No quiero compadecerte con mis lágrimas y angustias para que me des la vida, que mi voz no la procura; que bien sé que he de morir

\footnotetext{
188 Se refrenda el catolicismo nihilista de Calderón: Nada somos, nuestra vida verdadera no está en este mundo. Los pensamientos de Séneca encajan muy bien en esta perspectiva cristiana: "Cada día, cada hora, nos revela la nada que somos, y nos advierte con un nuevo argumento nuestra olvidada fragilidad: entonces nos obliga a meditar en lo eterno y a volver la mirada hacia la muerte." (Cartas a Lucilio. CI.)

${ }^{189}$ Dos líneas aportadas por el bululú para explicitar la entrada del personaje.

${ }^{190}$ El mensaje dirigido al rey de Fez es una estrategia didáctica en la estructura calderoniana pensada para la formación moral del espectador. La intentio hagiográfica y didáctica de la obra la aproximan poderosamente al subgénero del auto sacramental, incluso con la presencia alegórica del sacramento eucarístico en la oblación física (en cuerpo y sangre) de Fernando, e interpretando como personajes alegóricos a Fernando, de la santidad; a Enrique, de la prudencia; a Fénix, de la belleza; a Muley, de la amistad, y al Rey Moro, de la soberbia. El resultado objetivo es una tragedia de mártir cristiano.
} 
de esta enfermedad que turba mis sentidos, que en mis miembros discurre helada y caduca.

Bien sé, al fin, que soy mortal, y que no hay hora segura; $\mathrm{y}$ por eso dio una forma con una materia en una semejanza la razón al ataúd y a la cuna. Agora os lo explico: ${ }^{191}$

Acción nuestra es natural, cuando recibir procura algo un hombre, alzar las manos $\quad$ (alza las manos) $^{192}$ en esta manera juntas; mas cuando quiere arrojarlo, de aquella misma acción usa, pues las vuelve boca abajo porque así las desocupa. Pues fue cuna boca arriba lo que boca abajo es tumba; tan cerca vivimos, pues, de nuestra muerte, tan juntas tenemos, cuando nacemos, el lecho como la cuna. ${ }^{193}$

¿Qué aguarda quien esto oye?

Quien esto sabe, ¿qué busca?

Claro está que no será la vida. No admite duda.

La muerte sí; ésta te pido porque los cielos me cumplan un deseo de morir por la fe; que aunque presumas que esto es desesperación porque el vivir me disgusta, no es sino afecto de dar la vida en defensa justa de la fe, y sacrificar a Dios vida y alma juntas; y así, aunque pida la muerte, el efecto me disculpa.

Y si piedad no puede

${ }^{191}$ Frase conectora para facilitar seguir el discurso espiritual de Fernando.

${ }^{192}$ Varias didascalias implícitas se hacen explícitas en nuestra adaptación.

193 En estos versos se adelanta Calderón al pensamiento existencial del siglo XX: "Being situated is an essential and necessary characteristic of freedom": "Estar bien ubicado [en un sentido ético] es una característica esencial y necesaria de la libertad" (Sartre. Literature and existentialism. 150.) Fernando es consciente de su inminente fin y se dispone a un último ejercicio de libertad al retar al rey moro. 
vencerte, el rigor presuma

obligarte. ¿Eres león?

Pues ya será bien que rujas

y despedaces a quien

te ofende, agravia e injuria.

¿Eres águila? Pues hiere

con el pico y con las uñas

a quien tu nido deshace.

¿Eres delfín? Pues anuncia

tormentas al marinero

que el mar de este mundo surca.

¿Eres árbol real? Pues muestra

todas las ramas desnudas

a la violencia del tiempo

que iras de Dios ejecuta.

¿Eres diamante? Hecho polvos

sé, pues, venenosa furia; ${ }^{194}$

y cánsate, porque yo,

aunque más tormentos sufra,

aunque más rigores vea,

aunque llore más angustias, aunque más miserias pase, aunque halle más desventuras, aunque más hambre padezca, aunque mis carnes no cubran estas ropas, y aunque sea mi esfera esta estancia sucia, firme he de estar en mi fe; porque es el sol que me alumbra, porque es la luz que me guía, es el laurel que me ilustra.

No has de triunfar de la Iglesia;

de mí, si quisieres, triunfa; ${ }^{195}$

Dios defenderá mi causa,

pues yo defiendo la suya...

(Ve que se retira el rey Abdalá pero que llega otra persona.)

Se va el rey más ofendido.

Que tenga fe en este estado más le ofende y más le infama...

¡Vuestra majestad me valga!

Llega a cambio otro cautivo, leal amigo y soldado, ¡con una hogaza de pan! Amigo generoso y leal,

\footnotetext{
${ }^{194}$ Símbolos de la realeza son: el león, el delfín, el águila, la granada (el “árbol real”) y el diamante.
}

${ }^{195}$ El mensaje aquí de Calderón es que la vida de don Fernando es pasajera, pero eterna su causa. 
tarde llegas, que mi mal

es ya mortal... 196

(Toma el pan con el cuidado de una ostia consagrada, y al momento de partirlo le asalta un dolor de muerte. $)^{197}$

... Déme el cielo

en tantas penas consuelo. ${ }^{198}$

Pero, ¿qué mal no es mortal

si mortal el hombre es,

y en este confuso abismo

la enfermedad de sí mismo

le viene a matar después?

Hombre, mira que no estés

descuidado. La verdad

sigue: que hay eternidad

y otra enfermedad no esperes

que te avise, pues tú eres

tu mayor enfermedad. ${ }^{199}$

Pisando la tierra dura

de continuo el hombre está,

y cada paso que da

es sobre su sepultura.

Triste ley, sentencia dura

es saber que, en cualquier caso,

cada paso -igran fracaso!-

es para andar adelante,

y Dios no es a hacer bastante, que no haya dado aquel paso.

Amigos, a mi fin llego.

$$
\text { (Muere. })^{200}
$$

ANTONIO: Fernando murió el 5 de junio de 1443. ¿Así ha de terminar El príncipe constante, Pedro Calderón? Tu obra inconclusa es hermosa y bien triste. ¿Te satisface? Esta historia no se presta para una tragedia común y corriente, pero

${ }^{196}$ En el original de 1629 es Cutiño quien llega a compartir su pan.

${ }^{197}$ Así como Cristo ofreció en la Última Cena su cuerpo y su sangre en sacrificio para la salvación del mundo, así Fernando lo hace por la salvación de Ceuta y la defensa de su fe. La comunión (o eucaristía) es el máximo sacramento celebrado por los católicos.

${ }^{198}$ Estos dos versos corresponden al personaje de Juan de Silva en el texto de 1629.

${ }^{199}$ De nuevo se observa un antecedente para el pensamiento existencial del siglo XX. Sobre el propósito último de la literatura, Sartre escribió: "the writer has chosen to reveal the world and particularly to reveal man to other men so that the latter may assume full responsibility before the object which has been thus laid bare": "El escritor ha escogido descubrir el mundo y particularmente descubrir al hombre ante otros hombres, de modo que los posteriores asuman plena responsabilidad ante el objeto que, en efecto, ha sido revelado." (Literature and existentialism. 24.)

${ }^{200}$ Fernando aparentemente murió por disentería en medio de insalubres condiciones de cautiverio. "En el último periodo del cautiverio, cuando la idea del rescate parecía improbable, [Fernando] sufrió hambre y crueles tratos, hasta que expiró el 5 de junio de 1443. Su cuerpo embalsamado fue expuesto a escarnio, colgado de las almenas de Fez." (Valbuena Briones: 114.) En escenas posteriores de la versión definitiva de la obra, Calderón convierte a Fernando en una aparición fantasmal que guía a los soldados portugueses a la victoria final sobre los moros de Tánger. 
entonces tal vez querrás incorporar dos o tres momentos alegres, supongo, más personajes y un final venturoso que nos deje el consuelo de una redención espiritual. ${ }^{201}$ Quizá en lugar de acabar esta tragedia como tal terminarás haciendo una tragicomedia. ${ }^{202} \mathrm{O}$ tal vez tu obra llegue a ser tan profunda que podrá ser leída de muchas maneras. (Hace anotaciones al manuscrito.) Eso con respecto a ti, mi queridísimo Pedro Calderón. (Suspira.) Ahora quiero irme a descansar. De día le diré al cura que tu obra está muy bien, y que yo he cumplido... ¡Un momento! (Al Cielo.) Y conmigo, ¿cuál es tu juicio, Señor? ¿Por qué no escucho tu voz, o es que acaso es tu sentencia este silencio solemne... como de muerte? ¿Con qué respuesta he de volver a mi casa? ¿Qué van a pensar mi esposa y mis hijos? El mayor es un ángel tocando las cuerdas... y Sebastián está creciendo tan rápido... ${ }^{203}$ Dios mío, no me abandonen tu perdón ni tu gracia en esta hora prima, ${ }^{204}$ en mi prueba de fuego... Yo todo lo que quiero en este mundo o en el otro es ser un buen actor ${ }^{205}$ : Actuar para ti y para las personas que quiero y que me quieren, traerles belleza, alegrar sus vidas, llenar su espíritu y mostrarles otros significados y otras posibilidades del mundo: un mundo donde quepan todos los mundos. ${ }^{206}$ Dame tu licencia, padre mío, tu bendición, y yo seré el mejor actor que pueda ser... Sólo tengo esto para ofrendarte: a mí mismo... (Se hinca exhausto y suplicante, viendo algún resquicio o ventana al frente.) A lo lejos, en el horizonte, comienza a rayar el alba. El sol se acerca a iluminar mis oraciones en mi última escena en este lugar.

"Mejor que merezco estoy.

¡Qué de piedades aquí,

oh, señor, usáis conmigo!

Cuando acaban de sacarme

de un calabozo, me dais

un sol para calentarme.

${ }^{201}$ La tesis Arte nuevo de hacer comedias de Lope plantea darle gusto al espectador por encima de la rigidez de las convenciones estéticas. Es posible que en el caso de El príncipe constante, Francisco de Rojas Zorrilla (1607-1648, autor de Del rey abajo ninguno y Entre bobos anda el juego) haya ayudado a Calderón a adecuar su estilo en esa dirección para terminar de escribir la Comedia famosa... También es posible que lo hayan asistido actores como Antonio de Prado.

${ }^{202}$ María José Rodríguez propone que aquello que Lope de Vega inaugurara como "comedia nueva" en realidad debería ser explicado como una nueva teoría en torno a la tragicomedia: "la mezcla en una misma pieza de acontecimientos tristes y alegres" (La crítica ante el teatro barroco español. 14), subrayando cómo en 1616 el poeta valenciano Ricardo de Turia (seudónimo posible de Luis Ferrer y Cardona o de Pedro Juan de Rejaule y Toledo) defendió: "[...] ninguna comedia de cuantas se representan en España lo es, sino tragicomedia" (Ibid. 15, y en "Apologético de las comedias españolas...", cit. en La crítica ante el teatro barroco español. 48.) El buen ánimo de contrastar el pesimismo barroco con otros matices podría resumirse en una frase como: "Más Platón y menos Séneca" (aportación personal.)

${ }^{203}$ Sebastián de Prado siguió el ejemplo de su padre y fue uno de los actores españoles más reconocidos del siglo XVII. (Oehrlein.)

${ }^{204}$ La hora prima: Hacia las siete y media, exactamente antes de la aurora, según la regla benedictina (Umberto Eco. El nombre de la rosa. 15). También es la primera hora de la nueva vida de Don Antonio.

${ }^{205}$ La Real Academia Española ya se refería desde 1726 al buen actor como a aquel que "representa con primor" (Diccionario de Autoridades.)

${ }^{206}$ El teatro como imagen del mundo es una metáfora clásica del Barroco debida en mucho al mismo Calderón por su obra El gran teatro del mundo (1635, estrenada en 1641 por Antonio de Prado y publicada hasta 1655). También Shakespeare, desde el Teatro Renacentista Inglés o Isabelino, expresó: “All the world's a stage" en Twelfth Night (1601). El tema se remonta al Filebo de Platón y el Enquiridion de Epícteto. 
¡Liberal, señor, estáis..."207

... conmigo, que sólo soy un humilde aprendiz de actor!... (De pronto se da cuenta de que se ha reconocido a sí mismo.) ¿Qué he dicho? ¿Qué soy un actor? No, más bien dije que soy un... ¡Aprendiz de Actor! Ésta es tu respuesta, ya escucho ahora tu aplauso: austero, discreto... leal. ¡Gracias! Con eso me basta para respetarme a mí mismo y buscar cada día aprender algo nuevo. ${ }^{208}$ Dios te bendiga, Dios. (Se pone de pie.) Pedro: podrás haber escrito una hermosa partitura, podrás incluso hacerla pronto todavía más bella pero, ya que "en manos del actor está la vida del poema" ${ }^{209}$, pues soy yo quien pisa el tablao ${ }^{210}$, entonces ha de ser mi misión el representar la obra con primor y darle ánima. (Toma la espada. Recorta sus cabellos. ${ }^{211}$ ) Ahora: Que siga la función, pues en el teatro, tanto como en el mundo: "La vida es sueño y los sueños, sueños son.",212

(Actúa.)

ANTONIO: (Al REY ABDALÁ de Fez.) Bárbaro rey moro, gózate aquí
de que tirano quitaste
la mejor vida.
Mas presto verás castigo,
que por campañas y mares
ya descubro desde aquí
mis cristianos estandartes.
Subamos a la muralla
a saber sus novedades.
$\quad$ Es Juan de Portugal al frente de muralla.) $^{214}$
setenta y siete veces mil valientes lusitanos.
¡Embistan, portugueses! ¡Viva el Gran
Rey Alfonso! ¡Guerra, guerra!

${ }^{207}$ Don Antonio reza con palabras asignadas por Calderón a Don Fernando en el texto original.

${ }^{208}$ Con el tiempo Don Antonio se convertirá en uno de los maestros más respetados de la escena española.

209 "En manos del actor está la vida del poema", dijo el Pinciano (Philosophia antigua poética, 537 [524].) Mi tesis como actor-investigador propone: El actor es el alma del teatro. La literatura dramática cumple su función objetiva y la intentio autoral cuando el actor la representa sobre el escenario frente a su receptor final.

${ }^{210}$ Tablao: por "tablado." Se refiere a la duela de madera de los escenarios teatrales.

${ }^{211}$ Esto hacían los aspirantes a caballero después de pasar la noche velando sus armas y rezando. Julián Elliot describe el ritual: "En caso de guerra, el ritual de la investidura se reducía a la pronunciación de una fórmula [vg. 'Despierta del malvado sueño y mantente alerta, confiando en Cristo y loable en tu fama'] y a un toque de mano o de espada [el espaldarazo] sobre el escudero [el aspirante a paladín]. La ceremonia podía oficiarla cualquier caballero, aunque cuanto más eminente, mejor. Sin embargo, en tiempos de paz el proceso era más complejo. [...] En primer lugar, en señal de purificación, el escudero se bañaba. Tras ese bautismo, velaba las armas y rezaba toda la noche, generalmente vestido de blanco, símbolo de su limpieza interna y externa. Al amanecer, bendecido por un sacerdote, el aspirante era cubierto con una capa púrpura o roja, que representaba la sangre que estaba dispuesto a dar en nombre de Dios, y se le adjudicaban medias de color marrón, por la tierra, a la que debía estar dispuesto a regresar con valor si la ocasión lo requería. Un cinturón blanco (de nuevo un signo de pureza), espuelas de oro (que hacían referencia a su celeridad, la de un caballo espoleado, en el servicio a Dios) y una espada de dos filos (uno por la justicia y otro por la lealtad) completaban su indumentaria. El espaldarazo era el instante crucial. [...] El investido juraba ser leal y veraz, honrar y ayudar a las damas y asistir a misa diariamente siempre que le fuera posible." ("La vida por el honor", en Historia y vida. Agosto 2005. 47.)

212 "Y el mayor bien es pequeño, / que toda la vida es sueño, / y los sueños, sueños son." (Pedro Calderón de la Barca. La vida es sueño.) Se trata de una clara alegoría de la fugacidad de le vida... y del acontecimiento teatral.

${ }^{213}$ El parlamento original pertenece al personaje de Juan de Silva.

${ }^{214}$ Efectivamente, el histórico infante Juan de Portugal (hijo de Alfonso V y luego rey Juan II) conquistó el puerto de Tánger en 1471. "Setenta y siete veces mil" es una hipérbole sugerida por el bululú. 
(Combate con renovado brío. Tercera Batalla.

Tócase un clarín triunfante.)

¡Victoria! (Aprehende a la infanta hija de Abdalá.)

Date presa, princesa Fénix.

Rey Abdalá, ¿ahora quieres tú de vuelta a tu hija?

¿A qué fin si no eres capaz de procurar su felicidad, más ocupado como estás en ser un monarca cruel?

¿Ahora sí dejarás que se case con Muley? ${ }^{216}$

Entrega entonces el cuerpo de nuestro héroe Fernando que, tal y como hiciera el Mío Cid Campeador ${ }^{217}$,

ha de compartir aun después de muerto la

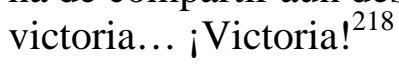

(Tocan cajas destempladas y alientos.

Amanece en la ermita de Sant Jordi.)

¡Qué tarde, cielos, qué tarde

le llegó la libertad a Don Fernando! ${ }^{219}$

No se invade otra tierra sin

pagarla con sangre humana. ${ }^{220}$ (Baja el ataúd.)

En mis brazos ya recibo

al divino príncipe mártir. ${ }^{221}$

Mirad dónde yace,

todos es bien le acompañen...

Al son de dulces trompetas

y templadas cajas marche

el ejército, con orden

de entierro, para que acabe

pidiendo perdón humilde

aquí, de sus yerros grandes, ${ }^{222}$

${ }^{215}$ En la obra, el sucesor de don Duarte, su hijo Alfonso V, el Africano, fue rey de Portugal de 1438 a 1481; casó con Juana la Beltraneja y guerreó en África y Castilla. Era sobrino del Príncipe Santo. Durante su reinado los portugueses descubrieron Guinea. En la dramatización de Calderón de esta última batalla, el espíritu de Fernando anima al ejército de Alfonso V, encabezado por Juan de Portugal (homónimo del soldado cautivo Juan de Silva), para conseguir la victoria. Los dos últimos versos son adaptación del bululú.

${ }^{216}$ Recordemos que Fénix y Muley están enamorados, pero su amor está en conflicto porque Fénix fue comprometida con el rey Tarudante de Marruecos. Su liberación, pues, es doble: tanto del ejército portugués como de Tarudante.

${ }^{217}$ Y mucho antes el héroe árabe preislámico 'Antar. La epopeya Sîrat 'Antar es popular desde tiempos remotos. En uno de sus últimos pasajes se lee: "aunque muerto, seguía a caballo. Su cuerpo se apoyaba en su lanza, mientras que Abjar [su caballo], esperando la orden de su amo, permanecía inmóvil como una peña. Y hasta el mediodía, 'Antar tuvo así a raya al enemigo." (Gustave Rouger. Las aventuras de 'Antar. 130.)

${ }^{218}$ La estrofa es una dramaturgia propia, siguiendo la estrategia bululú para adecuar la intención autoral a las condiciones objetivas de representación.

${ }^{219}$ Se sabe que Fernando murió el 5 de junio de 1443 (Valbuena Briones: 114) y que el rescate de su cuerpo fue hasta 1472, por negociaciones, un año después de la conquista de Tánger por Alfonso V. La exclamación corresponde a don Enrique en el original.

${ }^{220}$ Corolario post-colonialista del bululú.

${ }^{221}$ Don Fernando fue beatificado por la iglesia católica en 1470. 
el lusitano Fernando, príncipe en la fe constante. $^{223}$

(Don Antonio se persigna, guarda sus cosas en paz más que con euforia, apaga la lámpara y se va.)

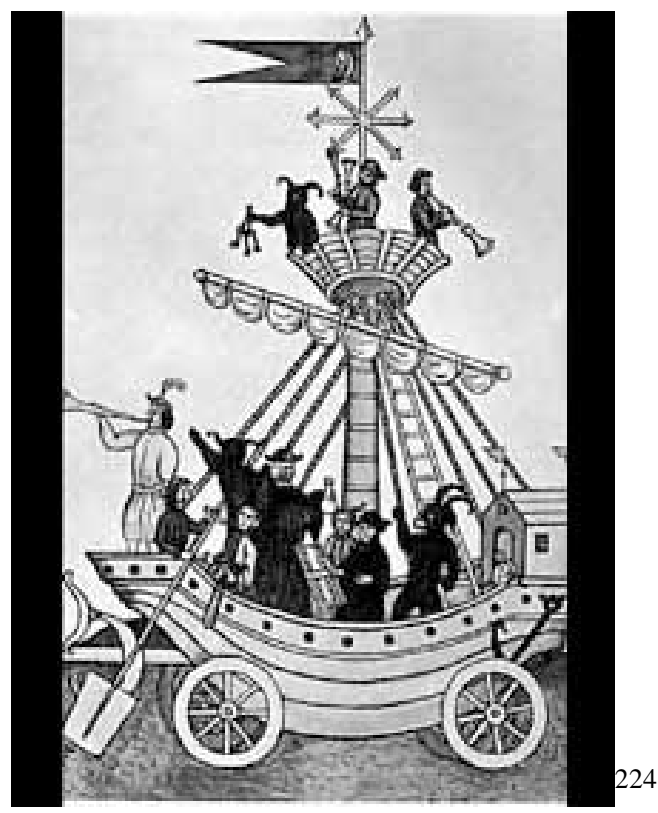

FIN DE LA OBRA

(Madrid, 1629 - Barcelona, 1996 - México, 2012) 225

\footnotetext{
${ }^{222}$ A pesar de sus muchas virtudes, calderón humaniza a Fernando dejando como indicios de error trágico la imprudencia de acometer la campaña de Fez sin la necesaria guarnición, así como la posible soberbia de un exceso de fervor religioso.

${ }^{223}$ En todas estas últimas líneas de la obra se funden parlamentos del rey de Portugal Alfonso, del rey de Fez, de don Enrique y de don Juan de Silva.

${ }^{224}$ Imagen de una representación teatral en Austria. Siglo XVII. Museo de Viena.

${ }^{225}$ Madrid, 1629: se escribe el primer borrador de El príncipe constante, perdido supuestamente en nuestra versión ficcional. Barcelona, 1996: aparece el manuscrito extraviado en el Park Güell, supuesto sitio de asentamiento original de una Ermita consagrada a Sant Jordi. México, 2012: Se restaura y fija cuidadosamente esta edición crítica de El príncipe constante.
} 


\section{CAPítulo VII: Primum Vivere, DeINDE PhILOSOPHARI ${ }^{226}$ \\ Ensayos, representación, recepción}

La creación artística es análoga a la investigación académica en tanto que también considera: hipótesis ${ }^{227}$, indagación ${ }^{228}$, experimentación ${ }^{229}$, análisis de $\operatorname{resultados}^{230}$ y el desarrollo constante de teorías, leyes y principios ${ }^{231}$. Nuestra tesis hace de esa analogía una relación dinámica al apoyar el estudio filológico integral de El príncipe constante de Calderón en su recreación escénica, y viceversa. En este capítulo haremos una evaluación de la ruta crítica del montaje teatral.

Es evidente que la leyenda hagiográfica del Infante Fernando parece contener más licencias poéticas (estoicismo inquebrantable, voluntad de sacrificio, aparición supranatural post mortem) que certezas documentadas. Sin embargo, esas mismas licencias nos hablan mucho de la emocionada agitación mental y espiritual que respiraría Calderón al momento de redactar su propuesta dramática y de diseñar su personaje, esto es, su muy personal Infante Fernando: El príncipe constante.

La versión apócrifa que propusimos, basada en un análisis arqueofilológico fino, rescata la intención original del autor de ofrecer un relato heroico y emocionante sobre el escenario, cuidando de respetar el contexto de producción en sus paradigmas originales:

\footnotetext{
226 "Primero vive [experimenta] y después filosofa [has crítica y teoría]."

227 Al igual que las investigaciones de Isabel Pascual Lavilla, "Nuestro pequeño trabajo parte de unos presupuestos muy definidos. Uno de ellos es la consideración del texto dramático [El príncipe constante de Calderón] como una 'hipótesis teatral articulada discursivamente' [Villalba García, María de los Ángeles, 'La gestualidad escénica en la comedia de capa y espada', Revista de Literatura, nº LI.101, 1989, pp. 55.], puesto que el drama, partitura virtual, solo se completa con su actualización escénica." (Isabel Pascual Lavilla, "Claves para la técnica de la representación del actor en el Siglo de Oro. Don Gil de las calzas verdes: Una propuesta de lectura y puesta en escena”, en Ars Theatrica-Estudios e Investigación [2003].)

${ }^{228}$ Montar una obra de teatro supone la búsqueda de un concepto estético coherente que abarca desde el tratamiento del texto dramático y su estilo interpretativo hasta el trabajo visual de escenografía, vestuario, utilería, atrezzos y efectos especiales.

${ }^{229}$ Una puesta en escena se construye sobre el ensayo y el error hasta el día de su representación y, a veces, incluso más allá.

${ }^{230}$ Todo teatrista profesional revisa, reflexiona y aprende de sus experiencias atesorando una memoria estratégica tanto de sus éxitos como de sus fracasos.

${ }^{231}$ En el teatro, la acumulación cuidadosa de tradiciones, usos y costumbres profesionales han dado paso a leyes y principios mejor conocidos como convenciones teatrales y teorías escénicas, llegándose en nuestros días al desarrollo primario de una semiología teatral (ver capítulo 2). De manera análoga, la sistematización de las experiencias actorales (Diderot, Stanislavski, Brecht, Grotowski) ha generado distintas teorías sobre la actuación, llegándose incluso a una antropología teatral (Barba, Savarese).
} 
1. Al igual que hicieran los autores de comedias (empresarios), los comediantes (actores) y los mismos poetas (dramaturgos) como Calderón de la Barca en el siglo XVII, las adecuaciones al texto han respondido a las condiciones objetivas de representación: elenco disponible, producción, espacio escénico y público. En otras palabras, se han seguido los protocolos más autorizados del siglo XVII para representar El príncipe constante en el siglo XXI.

2. El bululú fue un modelo de producción teatral vigente en la época de Calderón y la manera como se plantea la representación de El príncipe constante bajo esta condición respeta todas sus convenciones: un actor único (haciendo él solo varios personajes), una producción modesta (fuera de los grandes centros de espectáculos y apoyada en lo poco que cupiere en un arca), una sobria puntualidad en las ambiciones estéticas (un ejercicio minimalista neobarroco).

3. Antonio García de Prado (Madrid 1594 ó 95 - 1651), mejor conocido como Antonio de Prado, fue un actor verdadero que dejó su huella clara en la historia de España. Contemporáneo y conocido de Calderón, su prestigio como buen intérprete hace plausible que sea él quien imaginariamente represente el borrador apócrifo de $E l$ príncipe constante con las herramientas propias de un actor de su tiempo: "acción, memoria, lengua y osadía" (Lope de Vega). Nuestro ejercicio representacional expone ambas dimensiones del teatro barroco: la dramática de Pedro Calderón y la escénica de actores como Antonio de Prado.

4. La Cofradía de Nuestra Señora de la Novena es una corporación que desde el siglo XVII admite actores de reconocido prestigio no sólo artístico, sino también moral, y el ser admitido en sus filas (como lo hiciera Don Antonio de Prado) suponía en efecto pruebas de fervor religioso, compromiso moral y profesionalismo teatral, si no iguales, seguramente poco menos que equivalentes a la ficción propuesta por nosotros.

Nuestro siguiente cometido, nuestra "batalla", es reflexionar desde la conciencia misma del actor acerca de su participación en la construcción de sentido de un espectáculo: El príncipe constante, apoyándonos en el proceso de lectura e interpretación del protagonista de 
Calderón, para lo cual no bastará con interpretarlo crítica y teóricamente, sino que hará falta encarnarlo, esto es, representarlo escénicamente desde el cuerpo de un actor.

\section{De la hipótesis a la indagación}

Ya hemos establecido con claridad un análisis literario fino y una adaptación cuidadosa para la escenificación de El príncipe constante. Es lo que denominamos el trabajo de mesa: nuestra hipótesis teatral (capítulos 2 al 6 de nuestra tesis). ${ }^{232}$ Desde entonces comenzó la investigación, la búsqueda de una interpretación semiológica, genealógica, filológica. Este trabajo preliminar se puede sintetizar en los siguientes puntos:

1. "Estudiar la cultura tal como se manifiesta en su lengua y en su literatura, principalmente a través de los textos escritos." ("Filología", en $D R A E$.)

2. Respeto absoluto a la intentio dramatúrgica original, la cual consiste contundentemente en entender el texto dramático como una partitura.

3. Utilizar los usos y costumbres de los dramaturgos y actores del Siglo de Oro Español como "técnica que se aplica a los textos para reconstruirlos, fijarlos e interpretarlos" ("Filología" en DRAE) bajo una perspectiva espectacular.

4. Representar la obra El príncipe constante sin sacarla de su contexto históricocultural de producción, el Barroco, mediante la aplicación directa de la técnica teatral del actor trashumante conocido como bululú.

5. Se puede entender el trabajo de adaptación dramatúrgica como un ejercicio de restauración puesto que no se conoce una versión realmente definitiva ni coherentemente acabada de la obra (las diferencias entre el manuscrito 15.159 de 1629, la edición princeps de 1636 y la de 1640 pueden llegar a crear confusiones y ambigüedades ilógicas). Si bien el restaurar no puede pretender un reconstruir, el ejercicio sí aspira a crear una leal verosimilitud estética en los estándares históricos y filológicos de la obra literaria original.

6. Nuestra restauración intenta ofrecer una exploración de museo de la lengua y la literatura española del Siglo de Oro, pero también de los usos y costumbres de la

\footnotetext{
${ }^{232}$ Esta hipótesis no se resolverá sino con cada función, aunque el análisis textual y los ajustes interpretativos que implica se prolongarán más allá.
} 
entonces emergente profesión actoral, sus incipientes apuntes de teorías, leyes, principios, ideologías y parámetros estéticos.

7. El punto de vista arqueofilológico, lingüístico y estético para esta exploraciónrestauración es la participación del actor como un lector especializado en textos dramáticos. Este estudio se asienta sobre el texto mismo adaptado en los pies de página y en las escenas meta-teatrales (teatro dentro del teatro) de don Antonio, donde se discuten: la genealogía de la obra, la depuración de la dramaturgia, la aclaración de voces, acciones, costumbres y usos literarios y teatrales entre el Barroco y la actualidad; fijando, en fin, un sentido integral de la obra.

En otras palabras, la hipótesis teatral de El príncipe constante parte de que la obra es un modelo inacabado, inconcluso tanto en su composición (articulada con la falta de algunas señales que sólo pueden incorporarse en la representación) como en la misma intención autoral (cumplida sólo al ver lograda la interpretación escénica de la partitura teatral).

\section{De la indagación a la experimentación}

Ahora el actor se concentrará fundamentalmente en el proceso de construcción del personaje que estamos estudiando, dejando por el momento en un segundo plano las cuestiones de producción.

Es importante hacer notar que, aunque los ensayos teatrales pueden seguir muchos y muy variados métodos, en la mejor tradición eurocéntrica casi todos siguen un estándar de memoria del texto y memoria del trazo escénico que se traduce en un entrenamiento simultáneo de la mente, las emociones, la voz y el cuerpo del actor. Nosotros escogimos seguir una metodología que abreva mucho del sistema de acciones físicas de Constantin Stanislavski, apoyándonos principalmente en algunos elementos de dos de sus textos teóricos: Un actor se prepara y La creación del personaje, mismos que, en esta redacción, aparecen necesariamente sintetizados y/o parafraseados. Los primeros elementos a trabajar son las guías de un proceso de empatía artística del actor con su personaje:

1.¿Quién soy? La respuesta del actor, en función de su trabajo de caracterización, debe ser: el príncipe Fernando. Pero, realmente, es la forma de responder la 
que crea al personaje. Ésta debe integrar fundamentalmente al personaje dramático concebido por calderón de la Barca, pero no omite el perfil del personaje histórico, cuya información disponible puede ser recurrida por el representante. El director de escena y otros colaboradores (escenógrafo, músico y compañeros actores) participan también, mediante sus interrelaciones creativas, en esta construcción. Finalmente, la idiosincrasia del actor también condiciona el cómo se ha de "ser" Fernando de Portugal. Parte de la respuesta ya se tiene, pues fue elaborada durante el trabajo de mesa, consistiendo en varias lecturas de comprensión del texto dramático, tanto a nivel individual como colectivo (en nuestro caso con asesores académicos, directores y actores simpatizantes y una asistente técnica: Alejandra Juárez.) El resto de la respuesta se busca a lo largo de varios ensayos, conducidos por la noción o concepto escénico concebido por la dirección (en general: trazo escénico, intenciones verbales, equilibrio del grupo de actores; en particular, con respecto a la caracterización del rol: orientación de exploraciones emocionales, decisiones sobre el vestuario, el maquillaje, las entonaciones verbales y gestuales, etc.), y se busca también durante el entrenamiento individual: en los ejercicios de acondicionamiento físico (jogging, esgrima, acrobacia, danza, canto, expresión verbal y todo lo que Eugenio Barba analiza como la pre-expresividad ${ }^{233}$ o la plena disponibilidad del cuerpo del actor para el trabajo escénico), en la memorización en voz alta del texto (al menos tres repasos completos por día) y en el diálogo interior con el personaje (el verdadero trabajo empático.)

2.¿De dónde vengo? La respuesta a esta pregunta son las circunstancias dadas. Éstas se refieren al contexto histórico-ficcional del personaje, es decir, sus antecedentes diegéticos, diferenciados en inmediatos y distales. Para el caso de Fernando, nos dimos a la tarea de investigar. Así analizamos los acontecimientos históricos del siglo XV y su reelaboración dramática por Calderón en el siglo XVII. Fernando llega a Tánger con todo en contra: sin el apoyo de los nobles de la Corte de Leira, sin dinero, con pocos soldados y

${ }^{233}$ Ver La canoa de papel, Más allá de las islas flotantes y Anatomía del actor. 
mucho menos barcos y armas. A partir de esta precuela, in medias res de la mala fortuna, inicia la tragedia.

3.¿Adónde voy? Una vez adiestrado el cuerpo, la mente y el corazón del actor con la caracterización y las circunstancias dadas, el actor debe lanzarse a la escena con un único propósito: el súperobjetivo, mucho más claro si se plantea como la súpertarea. ${ }^{234}$ Ésta es la premisa primordial, definida desde el trabajo de mesa, que deberá guiar el pensamiento y las acciones del actor en su representación del personaje sobre en el escenario. En esta investigación propusimos ya una manera bastante precisa de cómo encontrar esta directriz actoral. Para Fernando, consiste en defender la fe católica con su vida, y todo su corazón, toda su mente y todas sus fuerzas apuntan a esa dirección.

Con los tres anteriores elementos se esclarece la identidad ontológica del personaje, en términos de José Ortega y Gasset, un: "Yo y mis Circunstancias",235. Con estas herramientas, el actor todavía tiene que acceder a una etapa más difícil, que tiene que ver con un intento consciente por disolver-ocultar su propia personalidad real en beneficio de materializar-exponer la personalidad ficticia del rol, es decir, asumir el personaje.

En un proceso creativo mal entendido, esto ha llevado a varias personas, quienes querían ser actores y actrices, a autodestruirse, pues varias veces hay quien ha querido convertirse realmente en el personaje interpretado, con el fin de darle un realismo absoluto a su representación. Es absurdo, desde luego, los actores sensatos saben que no se necesita matar realmente un ser humano para entender y representar artísticamente un asesino.

En un auténtico proceso artístico, debe suceder lo que propone Luis Villoro: "La voz de la creación puede ser oída en el momento en que abandonamos el apego a nosotros mismos. Ésta es una posibilidad de una ética superior.” (Villoro 2006: 5.) La ética filosófica de Villoro tiene sentido para el arte del actor, en tanto que reitera lo mismo que Stanislavsky al sugerir: "Ama al arte en ti mismo y no a ti mismo en el arte", planteando que la creación no puede ser un acto de vanidad ni de soberbia ni de irresponsabilidad.

\footnotetext{
${ }^{234}$ Un objetivo es algo que hay que alcanzar, en tanto que una tarea es algo que hay que hacer. Muchos actuales estudiosos de Stanislavski son quienes han aportado esta nueva orientación y, de igual modo, prefieren llamar a su escuela vivencial como el Sistema de las acciones físicas, en vez de meramente el Sistema Stanislavski.

${ }^{235}$ Ver La deshumanización del arte.
} 
Teniendo esta actitud bien clara, el actor está en disponibilidad de entrar en situación. Esto es que, en cada escena, vista como la unidad mínima de acción dramática $^{236}$, el actor caracterizado y con su personaje asumido debe llevar una línea de pensamiento que le permita hacer interactuar, lo más espontáneamente posible, a la súpertarea con las nuevas circunstancias que se vayan dando. En otras palabras, a pesar de que el actor ha ensayado repetidas veces una escena, su disposición ha de ser a la sorpresa, a la expectación de lo que va a vivir ficcionalmente, como si fuera real y como si fuera siempre la primera vez. El choque de voluntades entre el súper-objetivo y las fuerzas opuestas o antagónicas es lo que genera, a ojos del espectador, lo que Eric Bentley explicaba como la "vida del drama": el conflicto. ${ }^{237}$ Finalmente, si el actor está artísticamente en un momento de inspiración, se propicia entonces la creación libre y espontánea, casi inconsciente, de una emoción que conmueve tanto a actores como a espectadores en lo que todos desearíamos: un acto de verdadera comunión.

En todo este esfuerzo no hay que olvidar un detalle inobjetable, el cual es que, a pesar del trabajo de empatía, de caracterización y de asumir el personaje, no se puede ocultar realmente la experiencia personal del actor sobre la escena. Sabemos que lo que el espectador ve es una compleja mezcla entre las tradiciones orales medievales, Calderón, quinientos años de lecturas e historia universal, un concepto de dirección, un trabajo grupal y la experiencia personal del actor. Podemos hablar de una figura, más que de un actor o que de su personaje. Pero si en la proyección de esta figura, mitad ficción, mitad realidad, no se puede negar esa experiencia del actor como persona, entonces más vale aprovecharla.

¿Qué tanto debo entonces profundizar a nivel personal para una interpretación actoral del príncipe Fernando? No debe ser demasiado porque entonces el espectáculo se convierte en un acto de exhibicionismo por parte del actor, lo que opacará al personaje y al verdadero trabajo creativo, ni tampoco superficialmente porque entonces el trabajo creativo se vuelve frío, impersonal, sin compromiso. Por lo tanto, la respuesta ética y estéticamente más correcta sería: lo necesario.

\footnotetext{
${ }^{236}$ Se ha consensuado que la división interior de una obra teatral es en actos (o jornadas) y en escenas (o cuadros), así como que la unidad mínima de acción en el drama es la escena, entendida ésta como el principio, desarrollo y cierre de una situación significativa y no sólo como el mutis (entrada o salida) de un personaje al escenario. (Ver Bentley: La vida del drama; Lawson: Teoría y técnica de la dramaturgia; etc.)

${ }^{237}$ Ver La vida del drama.
} 
Todavía nos falta un ambiente donde el actor pueda experimentar con el análisis de su partitura para convertirla, poco a poco, en una experiencia palpable, visible, corporal. Ese ambiente no lo puede dar del todo un taller, dado que en un taller sólo se fabrica, se manufactura, pero no se reflexiona, y para esta investigación necesitamos reflexionar tanto como ejecutar las posibilidades escénicas que la obra propone. Tampoco nos basta el ámbito de un seminario pues, aunque en él se difunden valiosas semillas de conocimiento, se discute y se compara, la reflexión queda en el nivel de lo racional sin llegar a la práctica, y una investigación integral del texto dramático tiene que ser una indagación más vivencial. Un laboratorio es el espacio óptimo para desarrollar esta investigación, y el experimento idóneo: la puesta en escena de El príncipe constante, de Pedro Calderón de la Barca. En este sentido, toda puesta en escena teatral orilla a una apuesta extrema, vital.

He aquí el dilema clásico del personaje: ser o no ser. He aquí la conjunción que hace al actor: ser y no ser. (Luis de Tavira 1999, El espectáculo invisible: 45.)

Siendo nuestra escenificación de El príncipe constante más que una puesta en escena, es decir, una apuesta de laboratorio en donde el texto y el mismo investigador son los conejillos de Indias, decidimos no representar y reflexionar al mismo tiempo, puesto que la creación y la meditación son procesos diferentes, y entonces asumimos realizar ambas actividades (representar y reflexionar) por separado, de modo alternado, no sincrónico. El investigador necesita tomar distancia de su material de estudio para poder ser lo más objetivo posible. Asumimos tomar el riesgo de comenzar primero la puesta en escena y vivir la experiencia actoral en carne propia, con el mayor compromiso posible, y escribir con posterioridad al respecto.

Solamente de un actor que tiene el valor de enfrentarse consigo mismo puede salir una entrega amorosa de lo más hondo que tiene, y de eso se trata, que trabaje con lo más íntimo. Es una tarea dura, ya lo sé, pero una tarea sin la cual no existe el arte teatral. (Margules 2004, Memorias: 100.)

Por lo pronto, para interpretar al personaje en cuestión, al actor le llueven varias preguntas: ¿Cómo sería Fernando de carne y hueso? ¿Se tienen afinidades y/o parecidos con él, cuáles ocupar y cuáles no? ¿Qué hacer con los propios límites frente al personaje? ¿Cómo adaptar 
escénicamente un texto tan largo y complejo, y casi sagrado (para académicos puristas, principalmente)? ¿Cómo hacer para no descuidar todos los niveles de lectura de esta obra? ¿Cómo se debe representar El príncipe constante?

Un actor se puede tardar meses en organizar la vida para poner en un escenario esta obra teatral. Pensar demasiado en la producción suele ser el pretexto más efectivo para retrasar la tarea. Es complicado hacer coincidir las condiciones anímicas (la desconfianza en el virtuosismo propio), económicas (para sufragar vestuario, maquillaje, utilería, escenografía, la renta de un foro y, eventualmente, el salario de actores y técnicos) y humanas (hallar el equipo de trabajo ideal.) Para no esperar pasivamente el arribo de circunstancias ideales, se optó por realizar una versión de El príncipe constante con un elenco formado por una sola persona, a la manera de un joven aprendiz de letras y de actuación.

La gente joven, cuando se quiere dirigir con ella, aporta gran energía, frescura, alegría en el trabajo, contacto de seres que parecen condenados a la eterna juventud, y todo esto resulta muy agradable, muy grato. El director y el público reciben una enorme inyección de vida. (Margules 2004, Memorias: 107.)

Un actor no "es", sino que "está siendo" durante la representación. Si la representación es el espacio-tiempo en el cual el actor funciona de manera observable, entonces nuestro concepto escénico podría ser un experimento específicamente actoral (¿cómo lee un actor El príncipe constante?), con una ruta crítica que permitiera seguir y analizar los procesos creativos del actor.

Lo más importante para un actor que comienza, es darse cuenta de que no existe un sistema o escuela que lo vaya a convertir en actor; que tiene que buscar y diseñar su propio sistema. Cada gran actor tiene su sistema, pero sólo le sirve a él. Aprender a actuar, entonces, es aprender a construir nuestro propio sistema de actuación; el que mejor nos convenga, según el tipo de bicho que seamos. Una buena escuela de actuación es la que nos da el ambiente adecuado para que cada quien desarrolle su sistema; nos da información y nos deja en libertad para investigar, no nos impone su método. (Peter O’Toole, citado por Nicolás Núñez en Teatro Antropocósmico, 67.)

Montar El príncipe constante significa volver a ser un estudiante de teatro, o de letras, efectivamente. De ahí que lo mejor, como propone O’Toole, haya sido procurar un buen 
ambiente para el trabajo creativo y la investigación, mismo que generó su propio "sistema" o "escuela": un laboratorio actoral. Sin embargo, una primera indagación estuvo más asociada a la dirección que propiamente a la actuación. El propósito de esta dirección escénica fue:

Contar una historia interesante, en forma de acción dramática, lo más claramente posible, a un público determinado. (Carlos Piñeiro, "Elementos básicos de dirección”, 36.)

El producto fue una versión resumida de El príncipe constante de noventa minutos de duración, adaptada por un ejecutante teatral para un público especializado en letras (principalmente académicos universitarios) y para gente de teatro (actores, directores, dramaturgos).

En relación con la producción, y para concentrar la investigación en el desarrollo de la lectura actoral, los personajes serían reducidos (Fernando, Enrique, el Rey de Fez, Fénix y Fernando, interpretados todos por el actor barroco Antonio), y todos vestirían lo que pudiera caber en un arca (especie de cofre). La producción sería mínima, con el arca de madera mandada a construir (hecha por el Sr. Edmundo Aceves), con poca utilería y muy pocos implementos escenográficos (un icono de Sant Jordi para representar una ermita). El espectáculo se concibió para adaptarse a casi cualquier tipo de espacio (un teatro, un salón, una bodega, una capilla). Con este material, poco a poco empezamos a meditar sobre la persona que se convierte en un actor que se convierte en un personaje, su entrenamiento, su trabajo de mesa, las sesiones en el salón de ensayos y las condiciones que lo predisponen a su quehacer.

Hecha la primera adaptación del texto, la siguiente fase del montaje consistió en preparar una lectura dramatizada para estudiantes y profesores de la Preparatoria Iztapalapa 1 durante las XX Jornadas Culturales de ese plantel, buscando las intenciones primarias de los personajes, planteándonos dudas, haciendo comentarios y discutiendo críticamente, pero todavía sin definirse cómo habría de quedar la adaptación definitiva. La lectura dramatizada se presentó de las 18:30 a las 20 hrs del martes 16 de noviembre de 2010 en la Biblioteca del plantel mencionado, en la Antigua Cárcel de Mujeres (Iztapalapa, Cd de México). Fue prologada por el Mtro. Moisés Fuentes, especialista en lírica, quien resaltó el doble interés arqueofilológico de considerar un texto dramático del siglo XVII representado de acuerdo 
con los usos y costumbres de su propio contexto cultural. Esta fase puede abarcar hasta tres lecturas con sus correspondientes debates.

Estos debates tienen como objeto el conocimiento más general del texto y el establecimiento de la idea central, que funcionará en adelante como hipótesis de trabajo para el análisis dramatúrgico... (Carlos Padrón Montoya, "La puesta en escena a partir de un texto dramático", 61.)

Cierto es que en este espectáculo de lectura dramatizada la adaptación aún se mantenía muy apegada al texto original, con recortes básicos y muy breves inserciones explicativas a través de un representante ficticio bululú. La falta de una depuración más orientada a su resolución espectacular devino en cierta decepción en la relación actor-espectadores, con evidentes lagunas de comprensión, sobre todo del lenguaje y del contexto, en realidad del doble contexto (el argumento del héroe del siglo XV, su supuesta representación en el siglo XVII). Si la idea del segundo contexto ficticio (la representación de Antonio García de Prado) debía servir para aclarar, no para oscurecer, la obra de Calderón, entonces teníamos tareas pendientes.

Sin embargo, debimos mucho a esa primera exposición en público por los beneficios obtenidos al entender la recepción como retroalimentación objetiva, crítica y constructiva. Además, confirmamos la necesidad de entender al espectador como una presencia activa y no pasiva, y cómo su atención completa efectivamente el ciclo creativo de una obra teatral, un ciclo que sigue esta secuencia:

Historia real de Fernando de Avis > Drama de Calderón > Versión escénica > Espectador

En una nueva fase del montaje, se volvió a leer de manera aislada el texto varias veces, a solas, pero ahora corrigiendo entonaciones verbales y seleccionando escenas específicas que trazaran un hilo anecdótico principal sobre la idea central, escenas que tuvieran que ver directamente con la anécdota del príncipe Fernando, esto es, apoyándonos en un análisis 
actancial que destilara la síntesis argumental del relato dramático (dramema). ${ }^{238}$ Con base en esta selección, se afinó la adaptación recortando, parafraseando, agregando líneas, ajustando versos y metros hasta donde fue posible, todo en un acto único. En lugar de escenas y jornadas, se desarrolló un continuum donde las secciones de la nueva versión se señalan apenas por los mutis de los personajes. Asimismo, se determinaron poco a poco las entradas y salidas de los personajes en nuestra particular edición.

... se realizarán lecturas y debates más profundos para realizar la actualización, encontrar los puntos de giro, dividir la obra en unidades, establecer el punto de vista (confirmación de la hipótesis o idea central) y redactar la fábula. (Padrón Montoya, 62.)

Apoyados en la experiencia de la primera lectura dramatizada, se enriquecieron las intervenciones metateatrales de don Antonio García de Prado más explicativas acerca de la lectura del drama y su interpretación en los usos y costumbres actorales del Barroco.

El paso inmediato del montaje consistió en afinar, más que sólo comentar, en forma de micro-pasos escénicos (muy pequeños entreactos), el montaje hecho por Antonio, el actor español del siglo XVII, apoyándonos en imaginarios ejercicios de improvisación, siguiendo un proceso que en varios centros de formación teatral se suele denominar dramaturgia actoral. ${ }^{239}$ Esta dramaturgia actoral explica aspectos particulares de la obra y su contexto (elipsis hechas por la adaptación, como la anécdota paralela de Fénix y Muley; aclaraciones entre los rebuscamientos de la lírica original, como el sufrimiento físico de Fernando; usos y costumbres del teatro y los actores barrocos) en un lenguaje más coloquial, el de los hispanohablantes del siglo XXI, con notas (términos, expresiones, citas) que nos mantuvieran vinculados al Siglo de Oro; adaptó la producción de manera definitiva al número disponible de recursos materiales y humanos (escenografía, vestuario, maquillaje, tiempo, espacio, asistentes técnicos); llenó creativamente algunos huecos dejados por la reducción (con versos y frases propias, tal y como haría el ejecutante bululú); recuperó los fragmentos originales más significativos de Calderón (las tesis moralesestoicistas y dos importantes sonetos sobre la volatilidad de la existencia), y definió las tareas escénicas y la vida paralela de Antonio.

\footnotetext{
${ }^{238}$ Ver el capítulo "Dramema".

${ }^{239}$ José Sanchis. 1996. Apuntes del curso "Nuevas tendencias de la producción y creación teatrales en el área de la dramaturgia". BCN: Sala Beckett (inéditos).
} 
También el trabajo dramatúrgico arrojará: localización de bandos o tendencias (polos del conflicto principal), conflictos secundarios, modelos básicos del protagonista y demás personajes o caracteres, así como tipo de lenguaje a utilizar en escena. (Padrón Montoya, 62.)

En todos los ensayos solitarios se revisó una y otra vez esa dramaturgia actoral, afinando, recortando, agregando parlamentos, trazando el movimiento de todos los personajes en el escenario, el cual habría de ser la planta alta de una casa de cultura comunitaria. El uso de este centro, que es la Casa de Cultura Las Jarillas (en Iztacalco, Ciudad de México) ${ }^{240}$, definió una de las premisas que sería inamovible de nuestra concepción escénica: el máximo uso dramático de un espacio mínimo.

... se llegará a conclusiones sobre el estilo de actuación, la concepción de los decorados escenográficos [espacio escénico y escenografía], utilería, maquillaje y vestuario, las ideas preliminares sobre el trabajo de luces y los requerimientos musicales de la puesta en escena [iluminación y sonido]. (Padrón Montoya, 62.)

Se requirió un entrenamiento especial de la voz, con el fin de proyectarla adecuadamente en un espacio con problemas de acústica (reverberación, contaminación sonora exterior, irregularidad arquitectónica), sin perder una correcta entonación ni lastimar las cuerdas vocales. Se trabajó mucho el apoyo diafragmático (respiración) pero, mucho más, la precisión en la articulación del lenguaje (dicción), con el fin de proyectar la mayor claridad posible para un texto complejo (en verso, rebuscado y solemne). Se contrató a una asistente técnica y de dirección (Alejandra Juárez) que fungiera además como monitor-espejo que retroalimentara crítica y constantemente al actor-director. Con ludismo y humor, poco a poco se consiguió que Alejandra se expresara con completa libertad para criticar abierta y constructivamente a su propio "jefe". Como observa Nidia Vincent:

Al igual que el sueño, el sentido del humor aligera el peso de nuestras responsabilidades, la conciencia de nuestra fragilidad, el esfuerzo que implica establecer y mantener los lazos que nos unen a los otros, el miedo al ridículo y a la reprobación de nuestros actos. Sólo el humor nos permite dar la medida justa a las cosas y relativizar su importancia. (Nidia Vincent. "El cuerpo que ríe". 141.)

\footnotetext{
${ }^{240}$ La Casa de Cultura Las Jarillas se ubica en Av. Sur 109 esquina con Plutarco Elías Calles, colonia Ramos Millán, delegación Iztacalco, frente al metrobús Canela y a una cuadra del metro Coyuya. Tel.: 56495005.
} 
Mientras se desarrollaban estos primeros ensayos, buscamos también cómo ir complementando nuestra producción. Ya Rocío Arista (productora ejecutiva) había gestionado la construcción ex profeso del arca de madera (trabajo realizado por Edmundo Aceves) que fuera simultáneamente sobria (acorde con la pobreza del teatro trashumante), correspondiente con el contexto histórico (estilo vetusto), muy resistente (capaz de resistir el peso del actor de pie sobre él durante muchas funciones), fácilmente transportable (que cupiera en un automóvil familiar). También Rocío Arista nos había regalado ya una elegante espada toledana ornamental adquirida in situ (Toledo, 2005), de estilo medieval de acuerdo con los cronotopos medievales del protagonista de El príncipe constante (Fernando de Avis y Lancaster [1402-1443].) Algo del vestuario (un pantalón y una camisa) ya había sido utilizado en temporadas anteriores del Laboratorio de Teatro Libertad (Don Quijote, 2005) y su desgaste natural armonizaba con las condiciones de marginalidad descritas por Rojas Villandrando para los comediantes de la legua (lejos de las metrópolis).

Otro trabajo fue el desarrollo de una coreografía muy básica de esgrima. Un primer asesor fue el profesor de física y también cinta negra de kendo Alan García. Aunque las coreografías de combate fueron lo más arriesgado de montar, eso no pareció tan difícil como el desarrollo de toda la biomecánica de la puesta en escena, es decir, básicamente, justificar y afinar los detalles de cada trazo, gesto y entonación sobre el escenario.

Es muy importante que el actor se sienta cómodo con el movimiento marcado; para lograr esto, el director deberá explicar exhaustivamente la significación de esa acción. El actor, por su parte, deberá justificar -dentro de la línea de pensamientos y acciones de su personaje- el movimiento en cuestión. [.....] También la coordinación del movimiento con el texto será un objetivo a lograr. (Padrón Montoya, 63.)

Se sumó después la consulta de manuales antiguos de esgrima, que permitieran elevar la espectacularidad de un relato literario clásico e ilustrar visualmente el conflicto bélico y religioso entre los católicos europeos y los musulmanes berberiscos. 

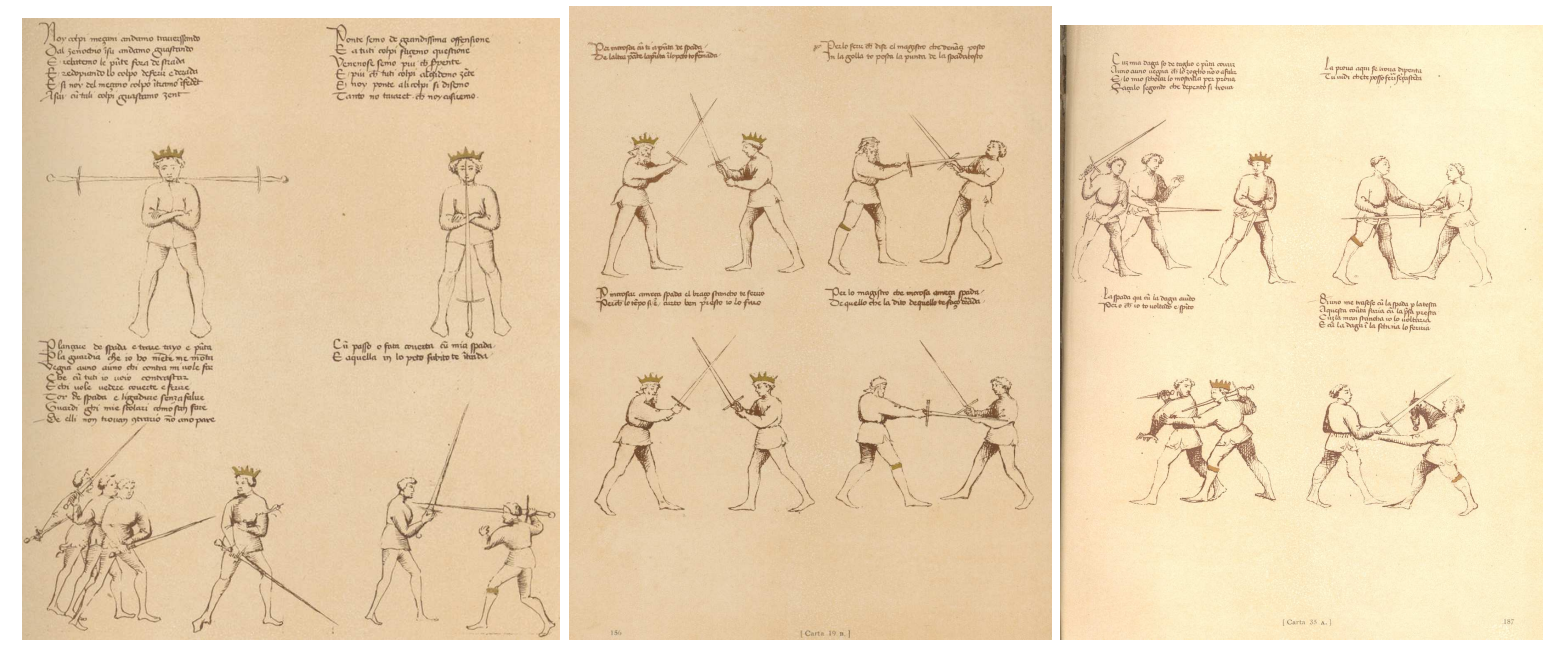

Fiore dei Liberi. 1410. Flos duellatorum

(En estas imágenes, históricamente próximas a la campaña real de Fernando de Avis, se aprecian cualidades y proporciones que deben tener las espadas para cada caballero; el combate entre personajes de distinta edad, alcurnia y capacidad numérica, y distintas formas de enfrentar, atacar y defender.)
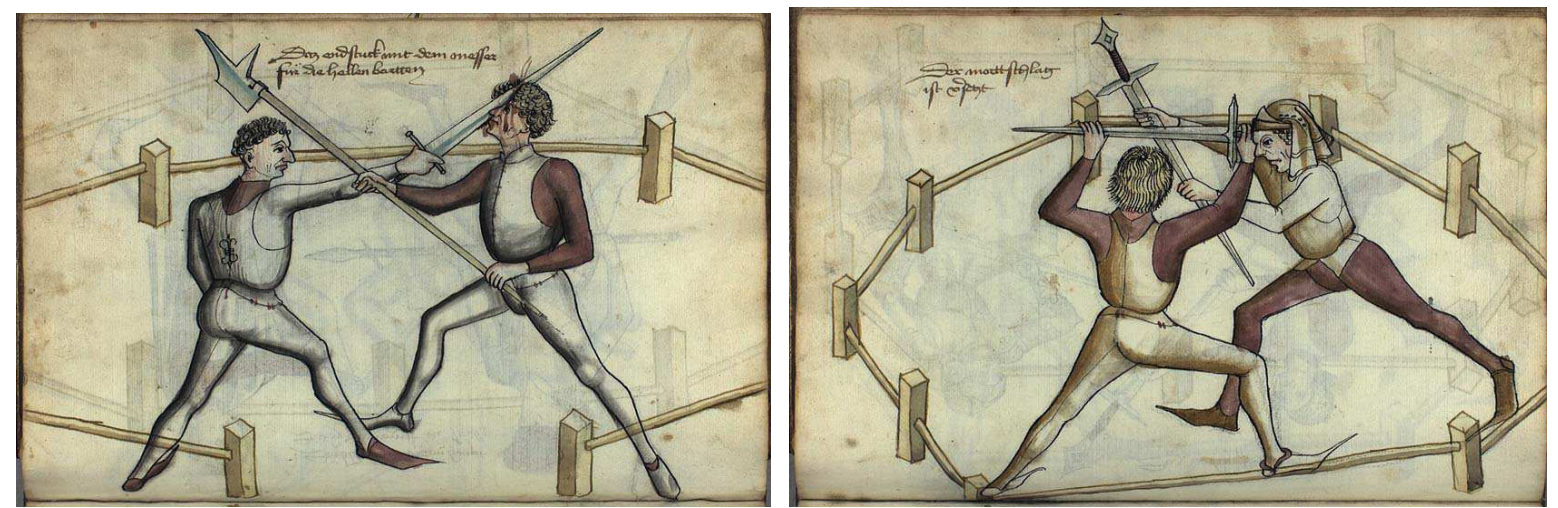

Hans Talhoffer. 1459. Alte Armatur und Ringkunst.

(En este otro manual, apenas posterior a la época de Fernando de Avis, se observan diversas maniobras con la espada en una arena especial para duelos o justas. Obsérvese, por ejemplo, en el segundo dibujo cómo el primer caballero toma su espada como escudo sujetando la hoja con la mano izquierda.)

A pesar de estos avances en la búsqueda de una gramática corporal equivalente a la lingüística desplegada por Calderón en su partitura, todos estos ensayos continuaron bajo un esquema básico de lectura dramatizada (lecturas en voz alta con guión en mano).

Se decidió eventualmente que las lecturas en la Casa de Cultura Las Jarillas fueran abiertas al juicio de cualquier espectador interesado. En su recepción, se reportó cierta sorpresa del público por lo arriesgado de la adaptación de una obra compleja y el manejo económico del espacio. En estos nuevos ensayos abiertos se trabajaron distintos aspectos: 
Búsqueda de profundización y de matices. Insistir en las justificaciones que no estén claras. [...] Trabajar en los pequeños detalles y añadir acciones físicas coherentes y significativas. Estas acciones pueden ser propuestas tanto por los actores, a menudo como justificación de movimientos, como por el director. En esta etapa, el actor debe ir midiendo la emoción y su control, al mismo tiempo debe crear toda la interrelación entre los actores. (Carlos Piñeiro, "Elementos básicos de dirección", 46.)

Se confirmó además que todo acto de lectura, incluso si consideramos como tal la representación teatral, exige una disolución, cuando menos parcial, de la figura autoral.

La escritura es la destrucción de toda voz, de todo origen. La escritura es ese lugar neutro, compuesto, oblicuo, al que va a parar nuestro sujeto, el blanco-y-negro en donde acaba por perderse toda identidad, comenzando por la propia identidad del cuerpo que escribe. (Roland Barthes. "La muerte del autor" en Textos de teorías y crítica literarias, de Araujo y Delgado. 221.)

En efecto, observamos que la interpretación del lector sesga a la persona del autor y su contexto de producción original en medio de sus propios backgrounds. En este sentido, una preocupación fue el cuidar no sólo la intentio sino además la presencia viva de Calderón en la representación de su obra adaptada, poniendo en discusión el espíritu estético de la literatura clásica universal frente a algunas posturas apocalípticas finiseculares, como la de Barthes (arriba) o la de Michel Foucault:

Mediante todos los ardides que establece entre él y lo que escribe, el sujeto escritor desvía todos los signos de su individualidad particular; la marca del escritor ya no es más que la singularidad de su ausencia; tiene que representar el papel del muerto en el juego de la escritura. (Michel Foucault. “¿Qué es un autor?” en Textos de teorías y crítica literarias, de Araujo y Delgado. 230.)

También se comenzó a poner a prueba la memoria del texto con técnicas similares a las siguientes:

Ensayos a la italiana. Existen dos procedimientos, ambos muy productivos: Primero, que todos los actores reunidos informalmente, sin posiciones fijas digan todos la letra a toda velocidad, sin pausas ni movimientos, aunque indicando los movimientos básicos y las acciones físicas principales que realicen verbalmente. Lo segundo es que los actores, en el escenario, realicen todos sus movimientos y acciones físicas diciendo la letra a toda 
velocidad, sin actuar, sino simplemente indicando superficialmente cómo van a actuar. (Piñeiro, 47.)

Se recordó el planteamiento de la representación como un ejercicio, un experimento donde no se prohibieran los errores, algunas fallas. Se había trabajado con una adaptación dramatúrgica que recontextualizaba el discurso de Calderón. Ese esquema permitía cierto margen, dentro de la línea argumental, para la improvisación, aunque no mucho. Así, poco a poco el trabajo se dirigía a su estreno formal.

Se decidió una fecha para estrenar oficialmente El príncipe constante de Calderón en Las Jarillas: el 28 de septiembre de 2011. Se invitó a académicos, a la prensa, a amigos y familiares. En realidad, por nunca sentirnos completamente satisfechos con nuestros avances podemos decir que se trató de un preestreno, con permiso incluso de acudir al guión cuando fuera necesario.

Algunos grupos teatrales realizan el denominado preestreno, que no es más que un ensayo general con público, al que usualmente se le invita a debatir la obra y el espectáculo en todos sus aspectos. (Padrón Montoya, 63.)

Esta audición bastó para ubicarnos en una realidad que antes no se había podido ver. Con toda sinceridad, el público criticó el trabajo. El montaje no tenía un nivel por encima del experimental, le faltaba claridad vocal, la adaptación había descuidado demasiado la ambigua complejidad del texto original y le faltaba fuerza expresiva.

Esto significó que hubo que trabajar más con el tratamiento de la obra en tanto que partitura y en el desempeño del actor, al concentrarse en desarmar vicios profesionales, así como en observar más objetivamente, para su análisis posterior, su proceso actoral: explorar más la diferencia entre cada personaje interpretado (Don Antonio, Fernando, Enrique, Abdalá y, en especial, Fénix); oscuridades del relato barroco en los parlamentos (aclarar, explicitar, recortar, incluso en ocasiones obviar); determinar más limpiamente la gramática corporal (caracterización de personajes, esgrima, femineidad de Fénix), y afinar la interpretación verbal (especialmente en la doncella Fénix). Para ello se determinó aprovechar la primera temporada formal de funciones en Las Jarillas como un nuevo ciclo de experimentación, como una serie de ensayos generales con un pequeño grado de innovación en cada representación. 
Ensayos generales. A los mismos deberán ser incorporados todos los elementos materiales y técnicos que se utilizarán en el espectáculo: el vestuario, los decorados, la utilería, los muebles, el maquillaje, las luces y los efectos sonoros. Es recomendable dividir estos ensayos en dos grupos: los ensayos técnicos, destinados a solucionar todos los problemas que se presenten con los elementos arriba citados, y los ensayos propiamente generales, para pulir detalles, darle unidad al conjunto y encontrar el ritmo definitivo del espectáculo, el cual varía según el género y la fábula. (Padrón Montoya, 63.)

Así se re-aprendieron: volumen, entonación, esgrima, combate escénico, coreografía, ritmo y disciplina profesional.

Para que las intenciones de un actor sean totalmente claras, con una tensión intelectual, unos sentimientos verdaderos y un cuerpo equilibrado, los tres elementos -pensamiento, emoción y cuerpo- deben estar en perfecta armonía. Sólo entonces el actor cumplirá el requisito de ser más intenso en un corto intervalo de tiempo de lo que es en su casa. (Peter Brook. La puerta abierta. 26.)

Fue interesante observar cómo al seguir con el proyecto se abatían los límites del actor: el pudor, la falta de mayor y mejor preparación acrobática, vocal, actoral, manteniendo el reto continuo de no ofrecer un espectáculo ni simple ni sencillo.

Los más graves defectos del actor son la pereza y la cobardía. Extrañamente sin embargo, la cobardía suele hacerlos laboriosos, tanto como la pereza los lleva a ser audaces. ${ }^{241}$

Por encima del placer de interpretar la obra, lo mejor de todo es: el crecer como lector, como investigador y como persona. Algo se deduce de esto: la actuación teatral exige ser mejores seres humanos.

El teatro ofrece diversos caminos a los actores que se allegan al escenario para colmar su vida del placer del arte. Unos consiguen la plenitud en la autocomplacencia; han venido a buscarse y el personaje es un camino hacia ellos mismos; son los conformes. Otros, consiguen olvidarse de sí mismos y sucumben al asombro del otro, el personaje es la puerta para salir de sí mismos; son los inconformes. Los hay mejores: aquellos pocos que logran superar lo que son y cambian para alcanzar a ser, por virtud del personaje, lo que pueden llegar a ser; son seres superiores. ${ }^{242}$

\footnotetext{
${ }^{241}$ Luis de Tavira. 1999. El espectáculo invisible. Paradojas sobre el arte de la actuación: 53. ${ }^{242}$ Ibid.
} 
Los comentarios al final de las sucesivas funciones fueron siempre de menos a más: de la descalificación más dolorosa al encomio más sincero. Desde luego, reconocemos que aun en los últimos comentarios que evaluaron el proceso artístico del Laboratorio, se reconoció más el empeño y el crecimiento cualitativo logrado, que el virtuosismo -en pleno proceso de madurez- del actor. Pero el objetivo se consumó: experimentar dignamente la puesta en escena como un reto actoral formativo: el del actor como lector.

\section{De la experimentación al análisis de resultados}

El estudio de la recepción en el teatro por el espectador parte, desde luego, de la teoría de la recepción.

La teoría de la recepción o, como también se le llama, la estética de la recepción, tiene como objeto central la investigación de las relaciones entre texto y lector. (Fernando de Toro 1987, Semiótica del teatro: 130.)

Aunque la definición de Fernando de Toro no nos deja lugar a dudas, la aplicación de la recepción al teatro debe desdoblarse despacio, si se quiere aprovechar mejor. John Howard Lawson (Teoría y técnica de la dramaturgia) ya tenía una opinión propia sobre la recepción teatral a mediados del siglo XX:

El público es la necesidad final que da propósito y significación a la obra de un dramaturgo. [...] El público piensa y siente sobre los acontecimientos imaginarios en términos de su propia experiencia. Pero el público enfoca los acontecimientos desde un ángulo diferente; la obra es la esencia concentrada de la conciencia y la voluntad del dramaturgo; él trata de persuadir al público para que comparta su intenso sentimiento respecto al significado de la acción. La identificación no es un puente psíquico a través de las candilejas; la identificación es la aceptación, no sólo de la realidad de la acción, sino de su significado. (Howard Lawson: 263. Énfasis mío.)

El mismo crítico indicó las principales dificultades para hacer del concepto de público, teoría:

He preferido analizar el proceso dramático partiendo del dramaturgo; podríamos haber llegado a muchas de las mismas conclusiones partiendo del público. Pero tratar de definir la teoría dramática mediante un análisis de las reacciones del público, sería una tarea mucho más difícil, porque implicaría muchos problemas adicionales. Las actitudes y preocupaciones del público al ver una obra son mucho más difíciles de medir que las de un dramaturgo al crearla. En cada momento de la representación, los distintos miembros del 
público están sujetos a una variedad infinita de influencias contradictorias, que dependen de la arquitectura de la sala teatral, la personalidad de los actores, las personas que los rodean, los informes que han circulado sobre la obra, y otros mil factores que varían de una representación a otra. (Howard Lawson: 263. Énfasis míos.)

Sin embargo, el público es una necesidad irrenunciable del fenómeno teatral. La cuestión, ante todo lo anterior, se resume en que: "Por tanto, el público es un factor variable, pero como desempeña un papel en la obra, se debe considerar su composición." (John Howard Lawson: 265.) Son recientes (relativamente) los logros en este tipo de estudios, y parece ser que ha sido la semiología la puerta a una teoría de la recepción teatral:

La recepción teatral es capital en el fenómeno teatral. El estudio se centra aquí en la relación teatral, es decir, en el intercambio que media entre sala/escena, emisor/receptor... [...] Quizás una de las razones por la cual la semiología teatral no se había ocupado de esta área [la recepción teatral] se deba al carácter hermenéutico de la teoría de la recepción, carácter muchas veces falto de rigor y en apariencia lejos de la semiología. No obstante, hoy el semiólogo debe integrar o más bien incorporar la recepción en el centro mismo de sus investigaciones, particularmente tratándose del teatro, donde la relación sala-escena es fundamental, puesto que no hay espectáculo sin un público, sin un espectador. (De Toro 1987: 13 y 130. Énfasis míos.)

La razón más pertinente para que exista una teoría o estética de la recepción teatral es, creemos, la que expresa Pavel Campeanu:

El teatro es espectáculo $\mathrm{y}$, por consiguiente, forma de socialización de las relaciones humanas que no implica al espectador en tanto que variante, sino en tanto que constante. Esta presencia no es alternativa, sino imperativa. Variante y alternativa es la manera de integración de los espectadores en el espectáculo teatral. (Pavel Campeanu en Helbo 1978: 107.)

Si en el teatro el espectador es un factor irrenunciable, entonces la teatralidad implica en sí misma toda una estética de la recepción. Pero la mayor singularidad de esta estética es su movilidad, es decir, la irrepetibilidad de su fugaz signo, porque, contrariamente a lo que sucede en el cine:

Una obra de teatro no se ve dos veces igual. Cada vez que los actores la interpretan, realizan un nuevo acto de creación, varían los matices subjetivos; estado de ánimo, salud, humor, etc., determinan, a cada instante, leves variaciones. (Castagnino 1967: 32.) 
Como vemos, este carácter variable se derivaría de la actoralidad, es decir, del trabajo del actor $\mathrm{y}$, por lo tanto, de la claridad y eficiencia de tal trabajo depende todo lo que fundamenta al fenómeno teatral, porque la comunión teatral consiste en lograr la relación entre el actor y el espectador.

A continuación compartimos un acercamiento alternativo a los conceptos de la teoría de la recepción, glosados lúdicamente desde una perspectiva teatral.

\section{Dramínimo}

Monólogo lúdico-monográfico por: $\langle\langle Y o\rangle>$

La pregunta por la existencia, en reconocimiento de la propia identidad, sólo puede responderse en la respectividad del otro. (Luis de Tavira en Ser es ser visto. 9.)

Personajes: Un actor-emisor y una espectadora-receptora.

Lugar: Escenario de un teatro de cámara. El telón está cerrado.

(La espectadora-receptora, o lectora, está sentada en las butacas desde hace rato, acaso aburrida, cuando se hace un oscuro y una pequeña luz se concentra sobre el telón. Entonces, el telón es abierto por el actor-emisor, quien da inicio a la enunciación de su parlamento o texto. Si la intención comunicativa del actor es eficiente, sin que surjan confusiones sobre la otredad, por ejemplo, entonces la espectadora debería prestarle su atención y algo llamado arte -o amor-podría surgir.)

ACTOR- (Se coloca una nariz postiza roja, de clown) Tengo la ansiosa intención de que me escuches, mas el arte -como con Job- no será sin tu atención. Aristóteles y Platón ya nos lo decían. Después de los formalistas rusos, fueron los estructuralistas franceses. Pero ni la semiótica de Greimas y Ubersfeld ni las teorías sobre el lector de Iser, Suleiman o Tomkins me explican ahora qué sucede con la recepción que tienes tú de mí. Te ofrezco la poiesis $^{243}$ de mi pasión. Recíbeme en una aistesis ${ }^{244}$ que desate su catarsis $^{245}$ hacia normas nuevas, para conservarlas o para transgredirlas. Sé tú la receptora de mis emisiones. Sí, lo

\footnotetext{
${ }^{243}$ Acto de creación de la obra de arte.

${ }^{244}$ Acto de atención hacia la obra de arte.

${ }^{245}$ Efecto de liberación psíquica o espiritual provocado por la obra de arte.
} 
confieso, yo era el autor explícito ${ }^{246}$ detrás de esa misteriosa retórica. Yo soy el ser de carne y hueso que firmaba por ese anónimo autor implícito, ${ }^{247}$ esos oscuros estilos. Ahora lo sabes. Te buscaba a ti, a ti, mi lectora implícita, ${ }^{248} \mathrm{mi}$ lectora ideal. ¿Te llegaron esas cartas? ¿Percibiste el aura ${ }^{249}$ que las envolvía? ¿O fue otra conciencia la lectora explícita, ${ }^{250}$ la persona real, interceptora de mis líneas, mis texturas, mis entramados lingüísticos? Mi amor por ti siempre estimuló aquella inmadura competencia poética, ${ }^{251}$ esa que evolucionó para hacerme construir los más complejos enunciados del deseo. Yo soy el sujeto de esos discursos; tú, el objeto de su pasión. ¿Y qué has hecho tú con tu competencia de lectora? ${ }^{252}$ ¿Ya descifraste mis subtextos, ${ }^{253}$ la oscuridad de mis intenciones? Acaso prefieres mantenerte virgen... intelectualmente quiero decir, es decir, olvidar el background ${ }^{254}$ que compartimos alguna vez, esa tierna estructura cultural heredada y enriquecida con nuestro común aprendizaje. Tal vez eso fue lo que pasó. Te independizaste para elaborar tu propio horizonte de expectativas. ${ }^{255}$ Claro. Nunca has estado obligada a esperar lo mismo que yo. Sin embargo, eso no te daba la libertad de entender lo que se te diera la gana. Ahora lo entiendo yo. ¿Por qué no exploraste mis subtextos? ¿Por qué me convertiste en tu vano pretexto $^{256}$ para escribir otra versión del amor? ¡No! Yo no soy tan ambiguo. No soy el libro, la obra abierta ${ }^{257}$ que otros te ofrecen. No necesito una lectura especial. Yo quiero que me leas con sencillez. Insisto, yo no te exijo ser un modelo complejo de lectora, ${ }^{258}$ yo tal vez te prefiera simple. Creo que ya hemos experimentado suficientemente los transgresivos sabores vanguardistas. Me conformo con que escuches el sentido único de mis actos de habla: ${ }^{259}$ ¡Ven a mí! Esta es toda la pragmática de mis cartas. Deja releer el

\footnotetext{
${ }^{246}$ Persona física que realiza un texto.

${ }^{247}$ Estilo personal de realización de un texto.

${ }^{248}$ Lectores potenciales, de acuerdo al contexto social, histórico y cultural alrededor del texto.

${ }^{249}$ Sensación de unicidad sobre una obra de arte (aquello que le hace única y original).

${ }^{250}$ Persona real que lee un texto.

251 La competencia poética se refiere a una capacidad artístico-creativa de la competencia lingüística (capacidad de expresión oral y escrita.)

252 Capacidad para comprender signos lingüísticos escritos.

${ }^{253}$ Subtexto: Sentido denotativo, indirecto, no literal, de un texto.

${ }^{254}$ Contexto cultural de referencia del lector, previo a una lectura.

${ }^{255}$ Suposiciones previas al acto de lectura.

${ }^{256}$ Intención previa a la enunciación del texto.

${ }^{257}$ Obra de arte que admite múltiples interpretaciones.

${ }^{258}$ Modelo de lector: Lector implícito construido, o previsto, conscientemente.

${ }^{259}$ Sentido pragmático de un discurso oral.
} 
acontecimiento de tu cuerpo. Actualicemos, ${ }^{260}$ recontextualicemos esta relación emisorreceptor. Está bien, yo tampoco te quiero ya pasiva, ${ }^{261}$ aunque nunca lo fuiste realmente. Reconozco que nunca leíste así, ni en mis más contundentes, es decir, cerradas súplicas. Asumo que no he sido el creador absoluto de nuestros placeres, mas tampoco el de nuestros horrores. Tú siempre dijiste la última palabra. Recuérdalo. Como lectora activa, ${ }^{262}$ has cocreado la historia de nuestros encuentros y desencuentros. Por todo esto, el valor de este mensaje cumple sólo una función contextual, es decir, dependerá de ti y tus nuevas circunstancias que logremos un pacto de cooperación. ${ }^{263}$ (Aquí se quita la nariz postiza.) Si mi intención no basta, entonces quizá tú puedas explicar mejor el significado de este pequeño relato, de este posmoderno y absurdo dramínimo. No pretendo ser un clásico, pero léeme. No encontrarás más nunca el mismo texto. ${ }^{264}$ Vuelve conmigo. Te extraña, El Otro. (Hace una reverencia y cierra él mismo el TELÓN.) ${ }^{265}$

\section{La recepción como retroalimentación}

El fenómeno de la recepción teatral puede tener dos perspectivas: la del público y la del actor mismo. La recepción vista desde la perspectiva actoral tiene el matiz de favorecer o de estimular la continuidad y el crecimiento de la desenvoltura en la representación, es decir, lo retro-alimenta. ¿Cómo es que el espectador retroalimenta al actor en el espaciotiempo de la representación teatral? Parte del misterio de la magia del teatro reside en la energía que el actor asegura percibir y recibir del auditorio. Después de haber puesto $E l$ príncipe constante en escena, podemos compartir algunas observaciones al respecto:

1.Es mentira que el actor se aísla completamente ignorando al público mediante una “cuarta pared.” Por más concentrado que esté el actor, siempre una parte de sí es consciente de que es observado desde afuera de la escena.

\footnotetext{
${ }^{260}$ Actualizar: Interpretar un texto a partir del marco cultural más reciente o inmediato.

${ }^{261}$ Nivel de lectura en el cual no hay interacción con el texto.

${ }^{262}$ Nivel de lectura interactiva, en el cual quien lee participa del acto mismo de creación del texto.

${ }^{263}$ Aceptación por parte del lector de las convenciones propias de una realidad paralela a la objetiva, que es la de la obra estética.

264 Texto: Enunciación oral o escrita. Por extensión, toda forma de discurso o mensaje con intención comunicativa, cuyo sentido, según la teoría de la recepción, depende del lector y se actualiza con cada nueva lectura.

265 ¿Te invito a cenar?
} 
2.Esa parte de sí, que es la misma que le permite diferenciar entre la ficción que representa y la realidad, está tan atenta del público que es capaz de percibir no sólo risas y susurros, sino también gestos tan mínimos como un matiz en una mirada, aunque no necesariamente de forma consciente. ${ }^{266}$

3.Como el actor debe mantenerse concentrado en su trabajo creativo, la atención que presta al público no logra cerrarse conscientemente a reacciones individuales de cada espectador, pero sí alcanza a formarse un panorama general de la colectividad: la idea de una reacción general del público.

4.Cuando el actor percibe que la reacción general del público no es la que desearía o esperaría, entonces su parte creativa (más emocional que racional y, por lo tanto, más subconsciente que consciente), juzga que algo no está funcionando, que no está trabajando bien, empezando por sí mismo. ${ }^{267}$ Esta micro-depresión es a lo que los actores llamamos "energía baja”, y corresponde a una retroalimentación negativa.

5.Cuando la reacción general del público se percibe como la esperada o deseada, entonces el subconsciente creativo del actor recibe un mensaje de aprobación, es decir, de estar haciendo bien las cosas, y esto lo estimula a continuar con buen ánimo y seguridad. A esta micro-euforia los actores la llamamos "energía alta", y es correspondiente con una retroalimentación positiva. $^{268}$

6.La retroalimentación del público hacia el actor no depende del número de espectadores. Podemos hablar de un enorme foro con todas las butacas ocupadas y, sin embargo, topar con una reacción desfavorable del público.

\footnotetext{
${ }^{266}$ Es a este fenómeno a lo que Stanislavski llama "soledad en público", aunque en su sistema sí hay un intento por pretender en el actor la sensación de la cuarta pared.

${ }^{267}$ Aunque no es el ámbito de nuestra investigación, puede ser interesante comentar lo que la ciencia estudia desde hace ya rato, y es la especialización de nuestros hemisferios cerebrales. Según estos estudios, el hemisferio izquierdo, que controla a la parte derecha del cuerpo, es analítica y calculadora, mientras que el hemisferio derecho, que domina a la parte izquierda del cuerpo, es sensible y creadora. Así pues, no sería extraño confirmar en algún momento que, a pesar de dirigirnos con una conciencia central, situada según estos mismos estudios en la parte frontal del cerebro, cabe que existan "subdirectores" neurológicos con responsabilidades bien diferenciadas.

${ }^{268}$ Como otro comentario allende a esta investigación, es posible que la retroalimentación positiva del actor coincida con altos niveles de endorfinas como la serotonina y la adrenalina, entre otras. Ya se ha demostrado la variación de estas sustancias en condiciones de meditación.
} 
Por otra parte, puede darse el caso de una función con sólo un espectador tan conmovido que su retroalimentación resulte realmente motivante. ${ }^{269}$

7.En el momento de la representación, es responsabilidad principal del actor el lograr captar, retener y hacer crecer la atención del espectador, aun si el texto dramático y/o la concepción escénica no son los óptimos. Esta responsabilidad implica buscar y lograr una comunicación entrañable con el público, de tal forma que las acciones del actor provoquen una reacción general positiva, de "alta energía", por parte del espectador.

8.Aunque la atención y reacción del espectador son principalmente responsabilidad del actor en el momento de la representación, tienen un fuerte peso la partitura, el texto dramático o el pretexto con el cual se escenifica, así como la concepción o idea general de la puesta en escena. Sobre esto hay que decir que, efectivamente, una buena historia, la forma de presentarla, personajes entrañables, acciones y sucesos asombrosos, etc., como en los textos de Shakespeare, son cautivantes, aunque durante la representación el espectador preste su atención más a lo que el actor hace, que a la historia que se presenta. De forma similar, imágenes, trazos y otros movimientos llamativos, decorados, iluminación, sonido, efectos especiales y muchas otras cosas que integran un buen concepto de puesta en escena, se pueden desarrollar implícitamente en la naturaleza física del $\operatorname{actor}^{270}$ y en su trabajo creativo.

9.También es importante el contexto cultural, del cual depende que el actor y el público puedan, aunque sea en un nivel esencial, comprenderse. Los actores entendemos que nuestro oficio nos hace investigadores de la comunicación humana, y que cada vez que subimos a un escenario, o iniciamos un

\footnotetext{
${ }^{269}$ Valdrá la pena que alguien investigue la influencia de las feromonas segregadas por la audiencia en la conducta del actor. Acaso sean similares al cortejo, si pensamos que el actor pretende el favor del espectador y que, si aquel lo hace bien, éste comienza a corresponderle desde complicados mecanismos biológicos subconscientes, como los enamorados.

${ }^{270}$ Ver Towards a poor theatre, de Jerzy Grotowski. El director polaco y su actor Rizard Cieslak demostraron cómo el cuerpo del actor puede ser una fuente de iluminación y una caja de sonidos no suficientemente explorados. En el mismo sentido, son las palabras, los gestos, la conducta del actor lo que transforma el espacio. Cuando un actor dice: "Ahora estamos en la superficie del planeta Marte", nos transporta y nos hace astronautas conquistadores con él.
} 
proyecto, estamos en la búsqueda del lenguaje esencial que rebase nuestras diferencias. El teatro es el mundo donde caben todos los mundos.

10.Un actor que decide ignorar la presencia del público no puede sostener, al mismo tiempo, que pretende comunicarle algo, pues son intenciones contradictorias. Tampoco puede esperar, incomunicado, ser retroalimentado. ${ }^{271}$

Además de en Las Jarillas, también se dieron funciones en el Auditorio de la UACM Casa Libertad, en la UAM-Iztapalapa y en el IEMS "Salvador Allende". Se puede decir que la temporada de El príncipe constante con el Laboratorio de Teatro Libertad como experiencia comunicativa fue muy afortunada. Tener el público a centímetros de distancia, usar el espacio de forma que el público se viera convocado por el frente, desde atrás o a través de la sala, el trabajo logrado en el volumen y la entonación, la proyección del justo control en las escenas de combate y en todo el trazo escénico, el rigor que se requería y la camaradería y el entusiasmo de un equipo pequeño de colaboradores en Las Jarillas fueron las vías para que los espectadores observaran, escucharan, compartieran a Calderón y respondieran, es decir, retroalimentaran el ejercicio, al final, con cariñosos aplausos.
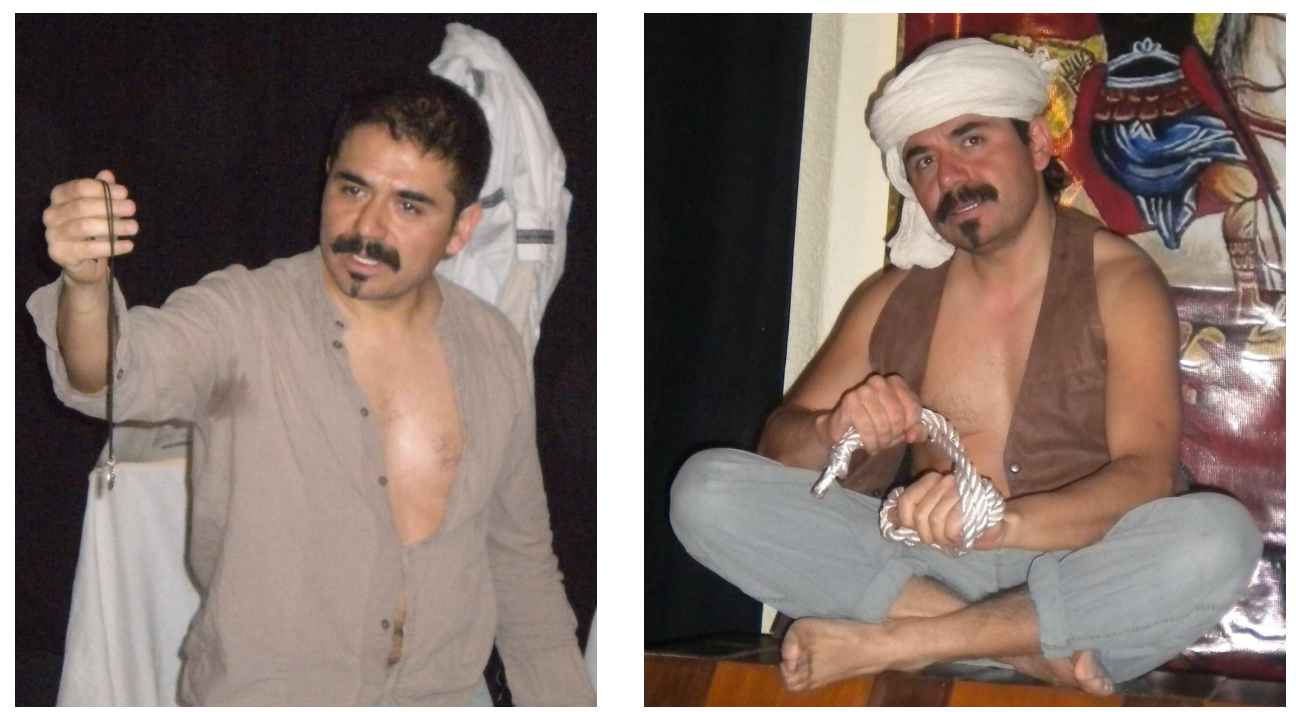

(Fotogramas de las funciones de El príncipe constante.)

\footnotetext{
${ }^{271}$ Cuando el mismo Grotowski se dio cuenta de que sus últimas investigaciones, más introspectivas, lo llevaban más allá del espectáculo, él mismo decidió, congruentemente, dejar de representar.
} 
Algunas funciones se dieron con muy pocos espectadores. Una muy memorable fue para estudiantes sordomudos, para quienes se realizó un esfuerzo particular en la expresión corporal. A veces fueron niños pequeños, ante quienes se adelantaba una introducción acerca de los "superhéroes de la antigüedad", y se cuidaron más el ritmo de la obra y las escenas de esgrima, de modo que fueran más atractivos.
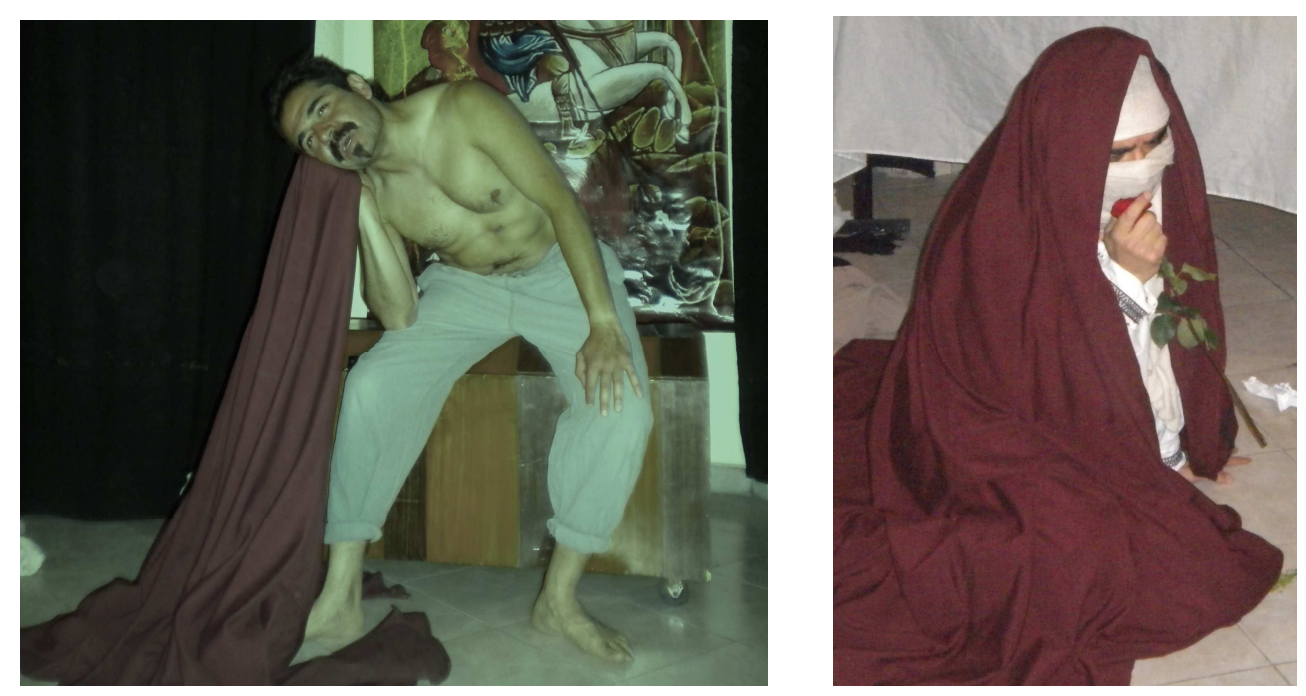

(Fotogramas de las funciones de El príncipe constante.)

Otro aspecto no muy evidente de la recepción teatral implica notar lo activo que puede llegar a ser el espectador. Para ello, lo primero es asumir que no existe un espectador pasivo, lo que ya hemos más arriba ponderado. Lo que sigue, es rescatar el valor de la atención del público como una actitud no sólo crítica, sino además artística.

La actitud crítica del espectador es sin duda una actitud artística. (Bertholt Brecht, Escritos sobre teatro, 138.)

Brecht justifica este pensamiento apoyado en el valor revolucionario y constructivo de la crítica.

Para introducir la actitud crítica en el arte hay que mostrar su indudable elemento negativo en su aspecto positivo: esta crítica del mundo es activa, emprendedora, positiva. Criticar el curso de un río significa mejorarlo, corregirlo. La crítica de la sociedad es la revolución, que es crítica llevada a término, ejecutiva. Una actitud crítica de este tipo es un momento de productividad y como tal profundamente placentero, y si en el lenguaje corriente llamamos 
artes a las operaciones que mejoran la vida de los hombres, ¿por qué el arte habrá de alejarse de esas artes? (Escritos sobre teatro, 153.)

Consecuentemente, no podemos sino admitir el peso colaborativo de la retroalimentación del público en la consolidación de la puesta en escena de El príncipe constante, y reconocer a los espectadores como cocreadores. Ello fue confirmado en sus críticas, constructivas o destructivas, que facilitaron evolucionar en el trabajo de lectura y representación con dudas, opiniones e incluso actitudes.

\section{Una función ritual del actor}

Desde antes de los ritos eleusinos, acaso en la penumbra de las cavernas o en la frondosidad de la selva, el ejercicio de representar mediante primitivas pinturas y esculturas la vida cotidiana de la tribu permitía establecer una relación más profunda con los animales que se iban a cazar, con las plantas que se veía renacer, con los antepasados que ya nunca regresaron y con las misteriosas fuerzas de la naturaleza.

En un espacio predeterminado, una buena cena, el calor de una fogata y algún brebaje preparado con raíces u hongos alucinógenos, o cuando menos embriagantes, propiciaba una fiesta en donde participaban los más nuevos junto a los mejores guerreros, las doncellas que ya supieran bailar y los individuos más longevos. Avanzada la celebración, con todos cantando y bailando con los ritmos de la vida evocados principalmente por tambores, uno de los ancianos más respetables grita de repente, con una voz que no parece la suya y con gestos que definitivamente no le corresponden por costumbre, que él no es él, sino que es otro. Afirma que es el abuelo del que todos cuentan historias pero del que ya nadie se acuerda, o bien, que es el tigre con el que han combatido cada primavera, o bien, que es la voz de la lluvia que desde hace varias lunas los abandonó pero que quisiera volver. Ya sea por la embriaguez o por el ánimo festivo, por el deseo de creer que las fuerzas desconocidas de la naturaleza son controlables o que se puede dialogar con ellas, por la necesidad de entender lo que aún no tiene explicación, o por todo junto, la comunidad acepta jugar en la efímera nueva realidad que se le propone y, así, todos bailan con ese "otro" encarnado en el chamán.

Ha nacido el "protagonista", el primer personaje ficticio que ha cobrado vida entre los vivos, casi como una persona real. "Casi", porque la fiesta termina, y el anciano recobra 
su identidad original. Todos aprenden que la función de médium se ha de dar sólo en las condiciones específicas propiciatorias de un ritual que entonces se hace sagrado y, desde luego, necesario para la salud espiritual de la comunidad. El protagonista, o primer personaje, es el primer ente agonizante que les celebra la vida, y les explica la muerte, con un sentido que va más allá de meramente sobrevivir. En su corta existencia, que dura únicamente lo que la fiesta sagrada permite, conecta a los hombres y las mujeres con todo aquello con lo que naturalmente no se pueden comunicar. Por esa misma corta existencia, el trabajo del chamán es un acto de ofrenda, de sacrificio, de generosidad por prestar su cuerpo entero, y arriesgar su alma, para que "lo otro" lo habite y pueda comulgar entre los vivos. $^{272}$

Como el más allá está lleno de misterios y de muchas otras "otredades", pronto otros personajes se hacen oír en medio de la fiesta, y es así como la comunidad puede asistir asombrada al diálogo mismo de los dioses. La primera réplica es llamada entre los antiguos griegos la del "deuterogonista", o segundo personaje, pero seguramente este encuentro ya se daba, como dijimos, mucho antes de que se viera en los bosques de Eleusis. Aunque el ritual sagrado no tardó en pasar de ser el diálogo cosmogónico entre los dioses a la representación del debate interminable de los hombres, es decir, en hacerse propiamente teatro, la función del actor en el subconsciente colectivo no ha cambiado mucho. Dentro del corazón del espectador que asiste a una representación, aviva el profundo deseo de encontrar, más que el mero entretenimiento, una respuesta alternativa a sus preguntas más esenciales.

No es que simplemente se aluda a lo sagrado o a lo desconocido, sino que se propicia un contacto efectivo con esa dimensión -el mundo de los muertos, los dioses, los fantasmas, los demonios, las fuerzas psíquicas más recónditas, los instintos. (Carmen Leñero 2003. 234.)

Como en las antiguas fiestas, los asistentes saben que la oportunidad de aprovechar este juego que fusiona realidad y ficción es efímera, que durará muy poco, y que deben prestar atención. El espectador llega a la función teatral con un ánimo predispuesto para creer, comprender y permitirse sentir, emocionarse, reflexionar. Por eso asistir al teatro nada tiene

\footnotetext{
${ }^{272}$ Para responder más claro a Barthes y a Foucault a propósito de la anteriormente citada "muerte del autor": Es contundente que a muchos lectores y actores un autor como Calderón nos inspira. En efecto, Calderón ¡inspira! Luego, si el "muerto" inspira, entonces no está tan muerto.
} 
que ver con ver televisión. El actor teatral, como los viejos chamanes, nos sigue conectando con infinitos universos paralelos, todos posibles y todos con infinitas posibilidades alternativas a la que ofrece este presente en este lugar. El teatro sigue siendo, en resumidas cuentas, mágico.

\section{El proceso del duelo actoral}

Al terminar la temporada de funciones de Cuarteto de Heiner Müller, bajo la dirección de Ludwik Margules en 1996, Laura Almela explicaba a Rubén Ortiz su impresión general de todo el proceso que vivió como actriz.

Fue como un clavado a la vida, a tintes de la vida que yo no conocía, que no había manejado a nivel de experiencia personal. La maravilla de hacer arte (lo digo entre comillas, creo que se ha sobreestimado esta palabra). De pronto te das cuenta de la cantidad de matices del comportamiento humano. Estoy como imbuida en humanidad después de este proceso. ("Entrevista" en Cuarteto, de Heiner Müller. [Bitácoras de teatro.] México: CONACULTA, 1997. 127.)

El testimonio muestra cuán profunda puede llegar a ser la experiencia teatral para un ejecutante y, de igual manera, lo difícil que puede ser digerirla y dejarla atrás. Para un actor, la experiencia escénica se vive como la vida misma, y hasta más intensamente. Mas el teatro, si ha de seguir siendo arte, debe quedarse en su virtualidad, en la utopía. La última fase del trabajo creativo del actor es, precisamente, la de escindir la figura actor-personaje. Se trata de un mecanismo consciente y temporal, equiparable a un duelo. Al final de una buena temporada teatral, tal y como sucede en las despedidas de amor verdadero, puede haber "perdón", pero nunca olvido. Esto es, que el actor puede -y debe- iniciar un proceso de resignación por no poder seguir representando más su personaje, aunque en su sentir crea que siempre llevará esa esencia ficcional incrustada, como si fueran las caricias de un ser querido que, habiendo tenido vida propia, tuvo que alejarse para siempre. Si es sano saber despedirse en la vida real, tanto más lo es en la dimensión límbica (entre real y ficcional) que es el teatro. El actor que no lo hace, se enferma de melancolía, sufre pesadillas y alucinaciones. El actor que lo logra - casi todos- está listo para iniciar una nueva empresa. 
La semejanza entre la actuación y la locura es evidente, escandalosa y frecuente; la diferencia en cambio, es sutil, rara y oscura: consiste en saberla. (Luis de Tavira, El espectáculo invisible. 33.)

Como en casi todas las fiestas, en el teatro el participante verdaderamente activo acaba completamente cansado y completamente feliz. Por eso, el actor ha de desprenderse de su maquillaje y de su vestuario teatral contento por haber hecho algo bueno en la vida, por haber aprendido cosas nuevas y por haber conocido personas y personajes entrañables.

Pero el actor no olvida del todo y, a pesar de resignarse a colgar su disfraz, la experiencia queda tan impregnada, que en realidad no vuelve a ser exactamente el mismo. Lo que profesionalmente se expresa como: "Tiene más tablas", en realidad quiere decir: "Ha vivido más."

We continually adjust our perceptions of reality to fit our own patterns of logic. In a vain attempt to control what we may not understand, or may frighten us, we skew the organic logic of life to fit a logic that comforts our individual egos. When an artist such as Shakespeare [o Calderón de la Barca] reflects truth back to us, he reacquaints us with that original logic, and in so doing gives us a clearer, truer picture than we are often capable of seeing for ourselves. He gives us a pure truth that entertains and enlightens, inspiring the artist within us all. (Doug Moston.) $)^{273}$

"Es un misterio", diría Tom Stoppard en su guión de Shakespeare in love. Y se trata, por otra parte, de algo que hacen casi todos los actores, consciente o inconscientemente: dejarse trasminar o mimetizar con su partitura, para contaminar o, mejor dicho, para enriquecer sus propias vidas.

Hay algo totalmente impredecible en la existencia escénica de una obra frente al público. Es este "misterio" lo que hace tan fascinante y tan temible a la vez a la producción teatral. El miedo y la fascinación (una cosa es parte de la otra) son las causas de la superstición teatral. (Harold Clurman, "La lectura de la obra", 29.)

Y, dado que el ser humano que se ha entregado a lo que verdaderamente ama, no es un ser arrepentido sino dichoso, así el actor que acaba de dar una función de teatro es feliz.

${ }^{273}$ Doug Moston. 1998. "Introduction", in Mr. William Shakespeares Comedies, Histories, \& Tragedies, A Facsimile of the First Folio, 1623. London: Routledge, iii. 


\title{
Capítulo VIII: Escenoma
}

\section{Apuntes para una micropoética de la lectura actoral}

\author{
"In recitante sonent tres linguae: prima sit oris, \\ Altera rhetorici vultus, et tertia gestus." \\ (Geoffroi de Vinsauf, La poética nueva. Siglo XII.)
}

Una de las misiones imprescindibles de una tesis doctoral es el desarrollar una investigación original que aporte un nuevo conocimiento. Ha sido hacia esa dirección que a partir de El príncipe constante de Pedro Calderón de la Barca hemos llevado a cabo una cuidadosa lectura arqueofilológica, semiológica, genealógica y estética desde un exhaustivo enfoque actoral representacional (llevado inclusive al extremo práctico-experimental). Este enfoque ofrece una perspectiva original muy adecuada para entender la naturaleza integral de la literatura dramática, tanto en su aspecto puramente literario como en su dimensión de partitura sólo consumada en el discurso escénico. La originalidad de la investigación se funda, además, en la incorporación de esquemas teórico-críticos contemporáneos (siglos XX y XXI) junto a los pensadores más cercanos al contexto cultural de producción (siglo XVII y aledaños). Ambas aristas: perspectiva actoral y actualización conceptual le dan a nuestra tesis la pertinencia de un nicho poco explorado pero necesario tanto para los estudios de la literatura áurea como de la teoría literaria. Por otra parte, un enfoque o perspectiva original no necesariamente ofrece nuevo conocimiento. A veces pueden simplemente confirmarse o refutarse datos anteriores. En nuestro caso, sin embargo, atestiguamos que el texto, las teorías y las suposiciones preliminares han enriquecido el campo de lecturas profundas posibles sobre la literatura del Siglo de Oro, específicamente sobre la dramaturgia calderoniana en el caso ejemplar de El príncipe constante, y que ese campo de lectura ampliado nos permite ahora perfilar una particular poética del actor como lector especializado. Que una pequeña poética de lectura haya surgido así, desde un análisis tan específico, nos habla de un proceso inductivo exitoso, y podemos decir que se trata de un modesto, pero en efecto nuevo, conocimiento. Precisaremos en este último capítulo los elementos, características, definiciones y alcances de este planteamiento. Advertimos que esta última sección de nuestra tesis puede parecer alejada del análisis literario original de $E l$ príncipe constante, incluso como cosa aparte. No es el caso. De cualquier forma, ofrecemos 
disculpas. Efectivamente, la literatura dramática y el teatro son dos ámbitos muy diferentes. Sin embargo, sus relaciones son continuas e inevitables, tanto que una no puede interpretarse cabalmente sin el otro. Aspiramos a que esta tesis abone a comprender esas relaciones y a no excluir de los estudios humanísticos al fenómeno teatral ni a su agente primordial: el actor.

\section{Una tarea aristotélica pendiente}

Aristóteles no nos habló sobre el arte creativo del actor. El capítulo seis del Arte poética de Aristóteles se titula Definición de la tragedia y Explicación de sus elementos. Sobresale que la tragedia sea "imitación de una acción esforzada y completa... actuando los personajes y no mediante relato, y que mediante compasión y temor lleva a cabo la purgación de tales afecciones" (1449b.24-28.) Toda tragedia incluye espectáculo, personajes (carácter), argumento (fábula), elocución (siempre en el lenguaje elevado o solemne del verso), canto (melopeya) y un tono político o retórico (pensamiento). Sobre el espectáculo dice: "es cosa seductora, pero muy ajena al arte y la menos propia de la poética, pues la fuerza de la tragedia existe sin representación y sin actores" (1450b.18-20). La lectura inmediata de estas últimas líneas explica el desdén histórico de teóricos y críticos hacia el trabajo del actor en la realización integral de la obra dramática. Evidentemente el comentario hace referencia a la fuerza lírica del drama, fuerza que esencialmente trasciende lo efímero de su representación escénica. En cambio, afirma que "el más importante de estos elementos es la estructuración de los hechos" (1450a.15 y 16), lo que conocemos hoy como la trama u orden en el que son presentados los sucesos en una narración o en un drama, "porque la tragedia es imitación, no de personas, sino de una acción y de una vida, y la felicidad y la infelicidad están en la acción" (1450a.16-18), de ahí que "la fábula es, por consiguiente, el principio y como el alma de la tragedia; y, en segundo lugar, los caracteres" (1450a.38 y 39.) Es evidente que Aristóteles percibe al espectáculo como un elemento constitutivo de la literatura, y que, al parecer, en aquel tiempo iniciaba a penas el análisis de ambos modos discursivos (el arte efímero de la representación frente al arte perenne de la escritura). El hecho de que, entre los elementos constitutivos de la tragedia le parezca la composición del canto (melopeya) el más importante (un elemento no registrable en el papel como para que su lectura ofreciera los mismos efectos que su representación en vivo), demuestra que no se 
había profundizado acerca de las peculiaridades de la puesta en escena. Ahora se sabe, por ejemplo, que hay aportaciones del actor sobre la escena que pueden matizar, o incluso cambiar, la percepción del personaje por el espectador. La tragedia, en consecuencia, no produce el mismo efecto sólo leída que cuando es representada por el actor. Más adelante, en el capítulo diecinueve, él mismo reconocerá que el arte de la representación escénica (el arte del actor) le es inabarcable pues en realidad carece de elementos para su análisis, es decir, lo desconoce y corresponde a otro ámbito de estudio.

El capítulo diecisiete de la Poética de Aristóteles se titula Consejos a los poetas. En él vuelve a su apología del realismo, sobre el cual ha de basarse la perfección de las historias y de los personajes: "pues, partiendo de la misma naturaleza, son muy persuasivos los que están dentro de las pasiones, y muy de veras agita el que está agitado y encoleriza el que está irritado" (1454a.30-33.) Es también de interés su clasificación de los artistas entre virtuosos y apasionados: "El arte de la poesía es de hombres de talento o de exaltados, pues los primeros se amoldan bien a las situaciones, y los segundos salen de sí fácilmente" (1454a.33-36.) Por otra parte, con respecto a la composición de los argumentos, recomienda primero esbozarlos en general y luego, puestos ya también los nombres a los personajes, introducir los episodios y su desarrollo. El filósofo observa además que en los dramas los episodios son breves, mientras que en la epopeya cobran mayor extensión. Hay que recordar que estos planteamientos no brotan del mero raciocinio o de la imaginación de su autor, sino que parten de una reflexión como lector-oyente-espectador atento y analítico, es decir, de un receptor crítico. Aristóteles refiere en todo momento dramas, epopeyas, cantos, danzas y poesías, y a sus autores, que compara para demostrar sus dichos. No habla mucho, lamentablemente, de los actores. Sin embargo, su clasificación de los artistas, a los que indistintamente llama poetas, es decir, creadores, sería útil para entender el temperamento de los actores, distinguiéndolos entre "hombres de talento" y "exaltados", interpretando a los primeros como los dotados de una técnica consciente y afinada en su quehacer creativo, y a los segundos como los que, presos de los trances de la pasión, crean verosímilmente, pero sin plena conciencia de su obra (muy cerca de como hoy distinguimos entre actores formales y vivenciales). También es pertinente al actor considerar en el análisis que Aristóteles hace de la estructura de la tragedia la importancia de una partitura (cualquier texto dramático, no sólo una tragedia) que, propiciando una correcta (verosímil) 
secuencia de tareas gestuales y verbales (acciones y diálogos), promueva la reacción positiva del espectador en el sentido de sorprenderlo (con obras inesperadas pero lógicas), conmoverlo (provocándole temor y compasión) y hacerlo reflexionar.

Sobre el pensamiento y la elocución es el tema del capítulo diecinueve de la Poética aristotélica. Aquí se determina que "corresponde al pensamiento todo lo que debe alcanzarse mediante las partes del discurso" (1456a.36 y 37.) Se refiere a los recursos de la retórica, de la palabra. Muy importante resulta lo que se dice con respecto a los modos de elocución, "cuyo conocimiento corresponde al arte del actor y al que sabe dirigir las representaciones dramáticas; por ejemplo, qué es un mandato y qué una súplica, una narración, una amenaza, una pregunta, una respuesta y demás modos semejantes" (1456b.811). Con esto, Aristóteles especifica que el ámbito del quehacer del actor (y también el del director de escena) es el de la interpretación verbal. También se deslinda (con gran honestidad) del estudio serio de un arte que no considera dentro del margen de su competencia: "en cuanto al conocimiento o ignorancia de estas cosas no se puede hacer al arte del poeta ninguna crítica seria. [...] Quede, pues, esta consideración a un lado, como propia de otro arte y no de la poética" (1456b.14, 15, 18 y 19.) Si mediatizamos la lectura de "seria" con un poco de atención, habrá que reconocer que el filósofo no está juzgando de poco serio al arte del actor, sino a la posibilidad misma de hacer ese juicio dado que no corresponde a su esfera de dominio. En otras palabras: Aristóteles no elabora una poética del actor.

Aristóteles considera que el ejercicio particular de la voz y su modulación es un dominio que pertenece exclusivamente a sus ejecutantes. Lo mismo podría decirse de su gestualidad, su expresión corporal. Es una lástima que principalmente por falta de una metodología clara para su análisis, el campo de la actuación no haya sido estudiado por el filósofo con más profundidad. De ahí que se nos negara por siglos la sistematización de una Poética actoral integral. ${ }^{274}$

Dejando de lado las rigurosas limitaciones de la teoría y la crítica para usar las ventajas y libertades de la narrativa ficcional, Umberto Eco propone una hipótesis acerca de cómo sería, o hubiera sido, una segunda parte de la Poética que en el imaginario de los

\footnotetext{
${ }^{274}$ Por "integral" queremos referirnos a una poética comprendida desde el entendimiento del sujeto creador de la obra artística conocida como actuación, y no solamente desde la perspectiva del espectador crítico.
} 
lectores más devotos de Aristóteles estaría dedicado precisamente a completar sus reflexiones sobre la comedia (cap. v de la Poética). En El nombre de la rosa plantea cuál hubiera sido el contenido general, de alto interés por cierto para los actores:

La comedia nace en las komai, o sea en las aldeas de campesinos: era una celebración burlesca al final de una comida o de una fiesta. No habla de hombres famosos ni de gente de poder, sino de seres viles y ridículos, aunque no malos. Y tampoco termina con la muerte de los protagonistas. Logra producir el ridículo mostrando los defectos y los vicios de los hombres comunes. Aquí Aristóteles ve la disposición de la risa como una fuerza buena, que puede tener incluso un valor cognoscitivo, cuando, a través de enigmas ingeniosos y metáforas sorprendentes, y aunque nos muestre las cosas distintas de lo que son, como si mintiese, de hecho nos obliga a mirarlas mejor, y nos hace decir: Pues mira, las cosas eran así y yo no me había dado cuenta. (Eco. El nombre de la rosa. 571.)

Vale la pena observar aquí el paralelismo entre la función social de la comedia propuesta por Eco en su versión apócrifa de Aristóteles y la función social del actor, llamado a veces comediante: Una idea superficial del actor nos lo suele presentar como alguien que miente, aunque en su arte de hecho nos obliga a mirar mejor sobre las cosas. Eco también aventura un primer párrafo apócrifo a manera de prólogo para esa sección perdida de la Poética:

En el primer libro hemos tratado de la tragedia y de cómo, suscitando piedad y miedo, ésta produce la purificación de esos sentimientos. Como habíamos prometido, ahora trataremos de la comedia (así como de la sátira y el mimo) y de cómo, suscitando el placer de lo ridículo, ésta logra la purificación de esa pasión. Sobre cuán digna de consideración sea esta pasión, ya hemos tratado en el libro sobre el alma, por cuanto el hombre es -de todos los animales- el único capaz de reír. De modo que definiremos el tipo de acciones que la comedia imita, y después examinaremos los modos en que la comedia suscita la risa, que son los hechos y la elocución. (Eco. El nombre de la rosa. 566 y 567.)

La elocución, es decir el dominio del arte del actor, vuelve a ser el modo por el cual el género consigue su eficacia. Acaso con mayor experiencia y observación Aristóteles hubiera dedicado alguna sección a la actuación. También es muy posible que no haya escrito nada más sobre la comedia ni sobre el actor que lo ya escuetamente contenido en los capítulos originales de la Poética. La Poética es considerada como una de las primeras y más importantes obras teóricas sobre arte, literatura y teatro. Los dichos del filósofo griego perduran como referencia dogmática, no sólo en cuanto a formas y contenidos de la poesía, sino como base de la tendencia realista que marcó el nacimiento estético de "Occidente" 
(entendido como una civilización eurocentrista). Sin embargo, leer esta obra como un mero recetario para los creadores, o bien, como un checklist para los críticos, trae graves riesgos:

Así, la hermenéutica tradicional del discurso original que comprendió al teatro como dimensión privilegiada del conocimiento, cúspide del hacer artístico y origen de la sabiduría, la Poética de Aristóteles, no sólo fragmentada y fragmentaria, perdida y hallada en un laberinto lingüístico irreparable, se convirtió en preceptiva y premática de una técnica literaria ajena a su realización escénica o en fundamento de una estética incapaz de discernir la realidad escénica del aquí y ahora efímero del teatro; o un capítulo de interés filosófico en la sistematización científica del legado aristotélico o recetario de fórmulas dramatúrgicas, incomprensibles fuera del contexto sistemático del pensamiento que la produjo. (Luis de Tavira. 2010. Interpretar es crear. 8 y 9.)

Con respecto del arte del actor visto por esa "hermenéutica tradicional" como accesorio prescindible, hay que advertir que:

Tal impostura de la tradición estética acostumbra justificarse en aquella afirmación aristotélica que desde una inexacta traducción del texto de la Poética parece considerar la representación escénica del drama como irrelevante para el discurso poético [vi.1450b.1820], cuando lo que en realidad confiesa Aristóteles con honestidad filosófica es la imposibilidad de su discurso para referirse a la consistencia efímera y variable del fenómeno escénico, al que reconoce como el más respetable enigma en que se realiza el acto poético de la mimesis dramática [xix.1456b.13-19]. (Luis de Tavira. 2010. Interpretar es crear. 5.)

Considero importante rescatar una llamada de atención sobre el talento, la técnica y las nuevas búsquedas escénicas para que, a partir de un trabajo más elocuente, pero no desmesurado, sino creativo, es decir, sugerente, sorprendente y emocionante, el actor provoque tal efecto en el público que ningún espectador, ni inocente, ni crítico, ni teórico, pueda considerar su arte como un apéndice innecesario de nuestro testamento cultural. Esto importa particularmente para la actuación teatral, pues ni el cine ni la televisión pueden registrar lo que significa una representación en vivo. Elementos específicos precursores para una poética del actor sugeridos en el Arte Poética de Aristóteles son:

1.Aristóteles sienta las bases generales para el estudio formal de la creación artística. Los actores no deberían ignorar nociones como: mimesis, tragedia, anagnórisis, catarsis, peripecia, fábula, trama. De Tavira resume, para el actor: 
Podemos entender la actuación como aquella poiesis [creación artística] que crea la praxis [quehacer orientado] que consuma la peripecia [desarrollo del conflicto] del drama en que consiste la existencia como personificación, cuyo efecto irracional es una catarsis [liberación espiritual mediante horror+compasión] cuya intensidad vital consigue la finalidad esencial del drama como arte. La anagnórisis, es decir, el conocimiento de la realidad como acontecimiento, esto es, como cambio. (Interpretar es crear. 9 y 10.)

2.Que los modos de elocución (la voz) son el dominio del arte del actor. Entre los griegos la actuación estaba predispuesta por máscaras y coturnos, lo que seguramente limitaba mucho el movimiento y la gestualidad. Desde entonces la aplicación de todos los recursos de la voz ha sido esencial para animar un personaje.

3.La tragedia todavía podría defenderse como el más elevado de todos los géneros literarios: drama (teatro), lírica (poesía), épica (narrativa), incluso ensayo (gnómico o doxal). Así lo seguimos pensando al releer: Edipo rey y Antígona de Sófocles, Hamlet y El rey Lear de Shakespeare, El burlador de Sevilla de Tirso, El príncipe constante de Calderón, Fedra de Racine, Madre Coraje de Brecht o De la calle de González Dávila; y las aspiraciones más altas en la carrera de los actores coincide con personificar personajes trágicos.

4.Aristóteles NO desarrolla una teoría sobre el arte del actor. Al observar que los modos de elocución son su dominio, además de referirse a la interpretación verbal y la expresión oral sólo deja en claro la forma tan compleja como es representado el discurso artístico frente al espectador, nada más (y nada menos). Desde entonces se sigue buscando e intentando construir una Poética actoral. Mientras tanto, no es correcto hablar de actores aristotélicos o no-aristotélicos.

Ya en capítulos anteriores observamos qué tanto se aportó a la elaboración de esa Poética del actor en el Barroco, el ámbito propio de El príncipe constante de Calderón. Veamos algunas definiciones que intentaron precisar desde aquel entonces una definición del actor para luego confrontarlas con las últimas ideas pertinentes a nuestra intención. 


\section{El actor como lector desde el Barroco}

En la búsqueda de una sistematización de los signos teatrales, ya hemos mencionado los esfuerzos de los teatristas españoles del Siglo de Oro, describiéndolos acaso más oficiosos que oficiales, esto es, más orientados a la profesionalización de su praxis que al desarrollo de una profunda teorización (Lope de Vega, Rojas Villandrando, etc.) Es notorio de todos modos cómo los intentos teóricos no han sido tomados lo suficientemente en serio por filólogos ni por estetas ni por filósofos.

En la mayoría de las obras de teatro la palabra juega un papel esencial (casos aparte son la pantomima, el teatro-danza, etc.) que ha sido analizado a profundidad en toda la historia de la crítica y la teoría literaria. No suficientes estudiosos realmente han reconocido el valor de la representación escénica. Sin embargo, la importancia del espectáculo, del oficio de los actores y de los decorados sobre el escenario, ya se hacía patente en estas palabras del siglo XVI:

En haziendo el poeta el poema actiuo, luego lo entrega a los actores para que hagan su oficio; de manera que, como muerto el enfermo, espira el officio del medico y empieça el del clérigo, hecho el poema actiuo, espira el oficio del poeta y comiença el del actor, el qual está dividido en las dos partes dichas, en el ornato o en el gesto y ademán; y, si no lo entendéys agora, escuchad: ornato se dize de la compostura del teatro y de la persona, y ademán aquel movimiento que haze el actor con el cuerpo, pies, braços, ojos y boca cuando habla, y aun quando calla algunas vezes. (Alonso López Pinciano, Philosophía Antigua Poética. Madrid: 1596. 534 y 535 [521 y 522]. Redacción original.)

Importa atender cómo mediante una ingeniosa comparación el Pinciano equipara el oficio del poeta con el del médico, que cuando muere el enfermo cede su puesto al clérigo. De ese modo, cuando el escritor acaba su tarea, empieza la del actor, y aún más diríamos de todo un complejo de elementos que en la actualidad la semiología dramática intenta abarcar en toda su extensión. Tradicionalmente, el estudio de la literatura dramática se ha limitado al texto escrito. Afortunadamente, se tiende cada vez más a estudiarla desde una perspectiva integral, que no omita lo espectacular. Se confirma que la palabra (ya escrita, ya oral), no es nunca el único elemento a tener en cuenta en la lectura de una obra dramática: el teatro es, además de literatura en la mayoría de las ocasiones (puesta en papel), espectáculo (puesta en escena), y por eso es el más complejo de los géneros literarios y el que conlleva, 
necesariamente, una recepción más dinámica. Continuamos esta consideración con otra puntual observación del Pinciano: "En manos del actor está LA VIDA del poema."

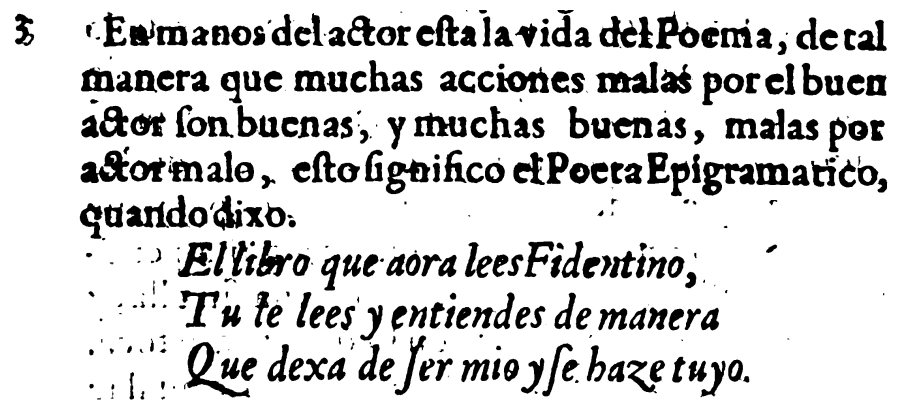

(Alonso López Pinciano, Philosophía Antigua Poética. Madrid: 1596. 537 [524].)

Como vemos, el Pinciano ya entendía que la literatura se transforma, por voz y cuerpo en vivo del actor, en una obra por fin acabada y completa, como si el actor escribiera las últimas frases, las determinantes del significado total, sobre la página en combustión del escenario. Como un resumen del universo barroco, el Diccionario de autoridades de 1726 concluye que lo propio del actor, aquello que lo define es, sencillamente, hacer: "Literalmente significa la persona que hace." Acto=acción, actuar=hacer, de acuerdo con las raíces latinas.

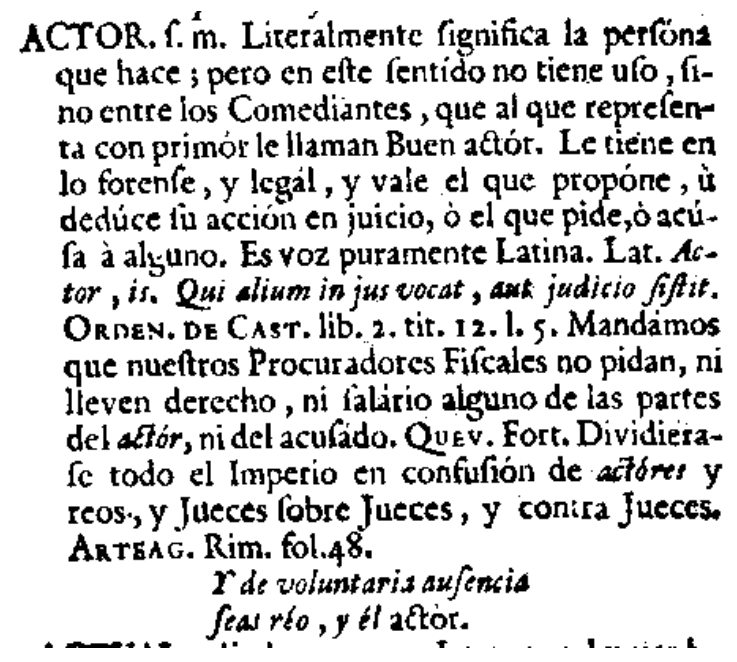

(Diccionario de autoridades. Madrid: 1726. 71, 2.)

Se precisa, eso sí, que entre los comediantes (o sea en el gremio teatral): "al que representa con primor le llaman buen actor." El primor es un concepto vigente hasta nuestros días: 
"Destreza, habilidad, esmero o excelencia en hacer o decir algo. Arte, belleza y hermosura de la obra ejecutada con él." (DRAE 2006: 1200.) Entre todas estas definiciones todavía ha hecho falta caracterizar las destrezas, las habilidades y el arte del buen actor, y es que también ha hecho falta tamizar nuestro conocimiento de la literatura del Siglo de Oro con el prisma de teorías más recientes.

Consecuentemente, conocer y apreciar las estrategias de lectura que desarrolla el actor teatral desde la exploración incipiente del texto escrito (en nuestro caso práctico con El príncipe constante de Calderón), pasando por todo el proceso de análisis, ensayos y representación, hasta su retroalimentación en la recepción del espectador, es pertinente para seguir construyendo la Semiología dramática, completar una Estética de la recepción y saldar el pendiente aristotélico de emprender una Poética del actor. Logrado lo último, vendrá el reconocimiento de que no solamente es el dramaturgo el poeta del teatro, pues lo es también el actor (en nuestro ejemplo con el espectáculo El príncipe constante).

Ya hemos hablado de los elementos básicos de una Semiología teatral a partir de los términos de Greimás, Ubersfeld y De Toro. Explicamos por qué conviene mejor hablar de semiología que de semiótica (para no omitir el signo lingüístico en la etimología). De ahí propusimos el matiz dramema para precisar el análisis del texto dramático con base en sus funciones semánticas internas y también planteamos la pertinencia de referirnos como discurso escénico al acontecimiento espectacular (en vez de texto espectacular). Además planteamos también los fundamentos para una Teoría de la recepción teatral para el espectador y una Estética de la retroalimentación para el actor mismo (una recepción más analítica y crítica del actor).

El uso que el actor hace de su cuerpo le permite evolucionar como lector, de ser pasivo-contemplativo a activo-vivencial. Al actor no le basta con apreciar, emocionarse y reflexionar con su lectura (sobre las aventuras y penurias de un infante portugués). La lectura del actor activa la máquina de su cuerpo para hacerse uno con lo otro: representar al personaje y sus situaciones (jugar a ser Fernando y vivir imaginariamente su martirio). El actor empata su vida real con la vida ficcional de la literatura. En ese tránsito, el compromiso del cuerpo es ineludible y eso lo hace una experiencia vivencial. Ergo: La lectura del actor es una lectura vivencial (leer El príncipe constante para un actor significa vivirlo). 
El hecho contundente de que la lectura actoral sea vivencial por naturaleza impide que el ejercicio sea superficial. El actor necesita primero, apenas lo dijimos, apreciar, emocionarse, reflexionar; pero luego también estudiar caracteres, acciones, justificaciones, conflictos, ideologías, nudos, expectativas truncadas y realizadas, resoluciones climáticas y anticlimáticas, contextos culturales del autor, de la obra, de sí mismo, intertextualidades; y todo ello traducirlo a los lenguajes de su cuerpo, para lo cual requiere un cuerpo dispuesto: físicamente entrenado, psicológicamente apto, atento a su mundo real y a ese mundo ficticio del drama, modulado en la experiencia y con la inteligencia suficiente para acertar en las orientaciones que exige cada nueva y particular interpretación. La lectura del actor es entonces profunda, pues su ejercicio empático le hace ver al otro como un ser completo o por completar. Además, la lectura del actor exige también prácticas de observación, comparación, jerarquización de información, discriminación, investigación. Entonces: La lectura actoral no solamente es profunda sino también compleja.

La importancia que estas observaciones tienen para los estudios de la literatura en general y para las teorías literarias en particular no son pocas. Primeramente, complementan el conocimiento de un arte tan complejo que hasta hace pocos siglos ${ }^{275}$ comenzó a tomarse como un quehacer serio: el arte teatral y a su oficiante el actor. El mismo Aristóteles reconoció que ese ámbito le estaba vedado por desconocimiento. El hecho de que hoy contemos con más y mejores herramientas para entender sus procesos creativos, así como para su análisis y sistematización es digno de apreciarse. En segundo lugar, hay que reconocer que las estrategias que hacen de la lectura del actor una experiencia estética profunda (vivir tal cual la literatura) no son de ningún modo impertinentes para ser aprovechadas por todo tipo de estudiosos y/o amantes de las letras. ${ }^{276}$ La práctica de la lectura actoral desarrolla además: la sensibilidad estética, el conocimiento por la literatura y el arte, habilidades de comunicación lingüística y corporal, actitudes solidarias para la lectura y el trabajo en equipo (la literatura como experiencia cultural comunitaria) y aptitudes de creatividad. En tercer lugar, es evidente que la lectura actoral

\footnotetext{
${ }^{275}$ Podríamos afirmar que es a partir del siglo XVI que se empieza a respetar profesionalmente el oficio del actor en su versión moderna-Occidental (acaso con la Comedia Italiana y el Teatro Isabelino). El teatro oriental es una historia aparte que partiría desde un punto que en otras latitudes llamamos Medioevo. Junto con la canonización social del estamento actoral aparecen las primeras notas preceptivas, reglamentos y apreciaciones estéticas.

${ }^{276}$ Ya hemos puesto como ejemplo a Goethe, muchas de cuyas lecturas las desarrolló como proyectos teatrales siendo él mismo uno de sus actores.
} 
facilita socializar la literatura (no sólo la dramática sino, mediante adaptaciones, también la narrativa, la lírica, la ensayística, e incluso tipos textuales no literarios), con lo cual se promueve su goce y estudio. El teatro genera nuevos lectores y desarrolla el gusto por la lectura. El actor y la actuación son agentes importantes para la promoción y difusión de la literatura, el arte, la cultura. Finalmente, si respetamos la obvia intentio del dramaturgo de escribir pensando en la escena, entonces es inconsecuente e inapropiado desconectar la posibilidad representacional que el texto dramático encierra y la participación indispensable del actor. ${ }^{277}$ Nos orientaremos a continuación a analizar un instrumento esencial para la lectura actoral, mismo que no contempla ningún otro paradigma de lector: el cuerpo.

El cuerpo del actor es ante todo el lugar donde se confrontan y ponen en diálogo o en crisis la literatura y el espectáculo. En el cuerpo del actor se vierten las sustancias del texto dramático para, con su imaginación y potencias físicas y emocionales, convertirse en renovada (actualizada, recontextualizada, reterritorializada) expresión artística. Ahora bien, para tomar el cuerpo del actor como base de apoyo para una Poética no podemos omitir las referencias más recientes que lo involucran.

\section{Antropología del actor como investigador}

Las inquietudes acerca del funcionamiento orgánico o corporal del actor, en busca de principios universales que valieran para todas las tradiciones o culturas, principalmente para las occidentales ante las orientales, han encontrado un cierto orden en los consensos de The Internacional School of Theater Anthropology (ISTA), fundada en 1979 con el impulso de un antiguo colaborador de Grotowski, luego creador independiente. Hablamos, desde luego, de Eugenio Barba y la antropología teatral. Una disciplina surgida de las inquietudes de Eugenio Barba, reúne a creadores e investigadores en torno a la naturaleza del actor:

Originalmente el término antropología era comprendido como el estudio del comportamiento del hombre no sólo a nivel socio-cultural, sino también a nivel biológico. ¿Qué significa entonces antropología teatral? Es el estudio del comportamiento del hombre a nivel biológico y socio-cultural en una situación de representación. (Más allá de las islas flotantes 184, se repite en 198 y en otras secciones y documentos.)

\footnotetext{
${ }^{277}$ Estamos obligados a insistir en que los estudios literarios a nivel internacional animan hoy al doble placer de entender la literatura dramática como texto literario y como partitura espectacular, y al teatro como fenómeno literario tanto como escénico: puesta en papel y "a-puesta” en escena.
} 
La materia principal de análisis de la antropología teatral es entonces el comportamiento humano sobre la escena. Es claro que el comportamiento del actor se deriva de su conducta cotidiana. Sin embargo, en escena ese comportamiento deja de ser cotidiano.

Utilizamos nuestro cuerpo de manera sustancialmente diferente en la vida cotidiana y en las situaciones de "representación". A nivel cotidiano tenemos una técnica del cuerpo condicionada por nuestra cultura, nuestra condición social, nuestro oficio. Pero en una situación de "representación" existe una utilización del cuerpo, una técnica del cuerpo que es totalmente distinta. Se puede, pues, distinguir una técnica cotidiana de una técnica extracotidiana. (Más allá de las islas flotantes 184 y 185, se repite en 203.)

La única y verdadera “discusión sobre el actor” en la cultura occidental, opina Barba, es la discusión que hace contrastar la "técnica de identificación" con la de "alienación" (Verfremdung [distanciamiento]). Esta discusión, que ha llevado a muchos malos entendidos, observa, encuentra sus raíces en un problema que no pertenece al mundo del actor. Empezó con Diderot y otros filósofos del siglo XVIII, en forma de discusión sobre problemas filosóficos y psicológicos que tan sólo utilizaban al actor como ejemplo. (Cfr. Más allá de las islas flotantes 371.) Para Barba, cuyo enfoque es transcultural, existen elementos comunes en todas las técnicas y tradiciones actorales. Las denomina principios que retornan, y se reflejan en tres aspectos:

1.La personalidad del actor, su sensibilidad, su inteligencia artística, su individualidad social que vuelven a cada actor único e irrepetible.

2.La particularidad de la tradición escénica y del contexto histórico-cultural a través de los cuales la irrepetible personalidad del actor se manifiesta.

3.La utilización del cuerpo-mente según técnicas extra-cotidianas basadas sobre principiosque-retornan transculturales. Estos principios-que-retornan constituyen aquello que la Antropología Teatral define como el campo de la pre-expresividad.

(La canoa de papel 27.)

Cuando el oficio del actor implica una búsqueda personal de su bios escénico, se despierta la actitud de un aprendizaje constante, la de un investigador.

La profesión del actor se inicia en general con la asimilación de un bagaje técnico que se personaliza. El conocimiento de los principios que gobiernan el bios escénico permite algo más: aprender a aprender. Esto es de enorme importancia para quienes eligen superar los límites de una técnica especializada o para los que se ven obligados a hacerlo. En realidad aprender a aprender es esencial para todos. Es la condición para dominar el propio saber técnico, y no ser dominados por él. (La canoa de papel, 26.) 
Aprender a aprender es lo que, de hecho, ya ha permitido que un actor como Stanislavski, quien constantemente se renovara, se volviera investigador y aportara entonces, además de una creación escénica original, un conocimiento estético significativo. Por esto es que se propone una indagación de la actoralidad desde la persona misma del actor (el ejecutante de El príncipe constante), en su quehacer individual y con sus propias reflexiones.

\section{La investigación actoral autorreferencial}

Hay que reconocer que, en general, las ideas sobre el actor y la actuación hablan bastante acerca de las técnicas profesionales de este quehacer, y sobre los modos en que el mismo es percibido. Sin embargo, en sus intentos por desarrollar hermenéuticas, estéticas, antropologías y semiologías que den cuenta de la creación del sentido teatral, los críticos e investigadores se quedan aún con preguntas abiertas. Estrictamente, la mayoría de estas preguntas solamente podrían plantearse al actor en el momento preciso de una escena, pero es improbable para el actor actuar y reflexionar sobre la actuación simultáneamente. Lo que no es imposible es aprovechar la sensibilidad y capacidad de introspección de un actor para que recuerde las líneas de pensamiento y emociones que, en forma de una conciencia paralela, acompañaban su trabajo creativo en el momento de la representación y, entonces sí, allende ese tiempo, y con base en herramientas teórico-conceptuales adecuadas, reflexionar lo más rigurosamente posible con miras a dejar, más que un testimonio, una explicación puntual de su trabajo, es decir, una descripción detallada de la participación creativa del actor en la generación de sentido en el escenario. Conviene, dada la complejidad del fenómeno teatral y la diversidad de contextos culturales en las que el teatro se practica, precisar como paradigma de nuestro estudio al actor dentro del contexto cultural occidental $^{278}$.

Si nos interesa conocer qué sucede exactamente, durante el lapso representacional, en el cuerpo, la mente y las emociones del actor que le permite capturar-del público- la

\footnotetext{
${ }^{278}$ Nos referiremos como "occidental" a la cultura, tradición o contexto histórico, político, económico y/o social iniciado con el ascenso de la clase burguesa europea durante el Renacimiento, extendido como forma de vida a América del Norte y Australia durante los siglos XVIII y XIX (como complemento ideológico de las campañas de conquista y colonización de los siglos XV y XVI), y consolidado con la hegemonía del imperialismo estadounidense durante el siglo XX (si bien el American Way of Life jamás ha logrado sustituir completamente los patrones de vida de las naciones a las que influye y, de hecho, la Comunidad Europea y varias etnias autonómicas latinoamericanas [México, Bolivia, Chile] cada vez parecen buscar más diferenciarse y marcar nuevas pautas).
} 
atención, retenerla y, finalmente, construir significados, es menester penetrar hondo en el trabajo del actor, ya que es quien da unidad al acontecimiento escénico. En el caso del actor teatral, una paradoja condiciona un juego de presencia-ausencia que se da sólo durante la representación: El espectador ve y no ve un personaje (el personaje es una ficción inexistente que se hace visible a través del actor.) El intérprete sufre también la ambigüedad de estar y no estar (lo que está en escena es una persona que niega su propia existencia en beneficio de la del personaje.) La paradoja convierte al actor en una suerte de $<<$ gato de Schrödinger>> que, en el interior de una caja herméticamente contaminada con gas letal, será considerado simultáneamente vivo y muerto mientras no termine el experimento cuántico. $^{279} \mathrm{~A}$ esta perspectiva actoral particular conviene ubicarla en algún lugar de la cartografía de debates teórico-críticos sobre la literatura dramática y el teatro y luego entonces, como parte de nuestra estrategia, le propondremos un nombre que la especifique. Recordemos acotar, entre todas las discusiones posibles acerca del drama y de la escena, que nuestro objeto primordial de estudio es el actor. Al respecto, el panorama no es muy preciso. La literatura teórica acerca del actor y la actuación en el siglo XX es mayoritariamente, al menos en intenciones esenciales, una bibliografía sobre el llamado training, es decir, acerca de la formación profesional del actor. Este enfoque fue imprescindible, como observa William Worthen (1997: 96), en el proceso de asimilación del arte teatral (él lo observa partiendo del teatro shakespeareano), que era antes considerado un mero divertimento vulgar, a la esfera de la "alta cultura".

Respecto al análisis particular del cuerpo de un actor entrenado antes, durante y a través de la representación de una obra, William Worthen hace ver la pertinencia de nuestra investigación al observar que: "Actor training is training of the body." (Worthen 1997: 99.) Así pues, nuestro trabajo deberá tocar constantemente las relaciones entre Calderón, concretamente desde el personaje de Fernando, y su corporización por el actor.

El interés de Worthen por el cuerpo del actor obvia la existencia de un instrumento de trabajo inalienable durante la representación teatral. En el desarrollo de nuestro diálogo con diferentes teóricos veremos cómo diferentes nociones de cuerpo aparecen una y otra

\footnotetext{
${ }^{279}$ Schrödinger planteaba un experimento hipotético, aparentemente nunca llevado a la práctica, para explicar el Principio de Incertidumbre, el cual consistía en comparar nuestro conocimiento sobre el estado de un electrón en un átomo a una caja hermética en donde se hubiera encerrado a un gato con un gas letal. Para la física cuántica, el gato estaría simultáneamente vivo y muerto, mientras no se abriera la caja para observarlo directamente. De la misma manera había que apostar a la posición o el nivel de energía del electrón.
} 
vez. Entenderemos nuestra idea de cuerpo no en el sentido de un material manipulable, es decir, como títere o la "súper marioneta" a la que se refiere Gordon Craig, sino a un organismo inestable o, en los términos de Deleuze y Guattari, un plan de consistencia o máquina de guerra (definición también adoptada por el director polaco-mexicano Ludwik Margules para el actor teatral [en 2004, Memorias: 152]), dicho en otras palabras, una construcción teórica que represente en esta investigación a la persona-objeto de estudio que es el actor. La institucionalización del training, según Worthen, devino en tres tipos de texto:

1. Sobre el primero dice: "The most influential writers/teachers/directors consider actor training within a palpable, if sometimes vaguely defined, commitment to reform the aesthetic and ideological mission of the stage." (Worthen 1997: 96.)

2. "A second genre [...] is more directly and extensively concerned with training the actor's 'instrument' for the professional theatre." (Ibid.)

3. "A third kind of writing about acting has come to bear directly on discussion of Shakespearean performance: books and essays written by actors." (Worthen 1997: 97.)

En esta clasificación podemos notar que un estudio rigurosamente actoral abreva directamente de la tercera clase de escritura (un estudio en primera persona), y es ahí en donde debemos inscribirlo, como un ensayo autorreferencial (o una serie de ensayos propioceptivos) acerca de la actuación. Un ensayo autorreferencial compromete, entre otras cosas, reflexionar -más o menos filosóficamente- en torno a una experiencia personal. Luis Villoro defiende la pertinencia de involucrar la experiencia personal en una reflexión filosófica:

La reflexión filosófica siempre tiene como última raíz experiencias personales, vividas. Experiencias que si son vividas intensamente vuelven más fuerte la manera racional en que tratamos de vivir con ellas. Entonces creo que estas experiencias personales son las que no se borran en toda la vida y son las que dan lugar, luego, al racionamiento. Yo no creo en una razón separada de estas vivencias emotivas, personales. La razón es el desarrollo y la expresión, mediante categorías rígidas y racionales, de las experiencias vividas. (Villoro, mayo de 2006: 5.)

Pero los actores, más que pensar o cuestionar, actúan, hacen. Su ambiente natural es el de la acción. La escritura actoral es la del discurso efímero de la representación escénica, y no aquella más perdurable que rasca el papel. Por ello es que tradicionalmente los actores adolecen de método y de rigor para llevar a cabo una investigación. Más que para otros 
humanistas, para el actor la investigación metódica es comparable a un laberinto. Sin embargo, hay actores que no sólo actúan. También hay actores que piensan en el sentido de que se cuestionan, buscan respuestas, generan ideas y las escriben. Entonces es posible la existencia del actor-investigador.

Se hace y se estudia teatro porque nos interesa la vida, porque nos gusta, porque nos agrada vivir. Se hace y se estudia teatro por amor. El teatro no sólo representa la vida, también la multiplica para el actor y para el espectador, al abrir ante sus sentidos otras posibilidades cósmicas (al mostrar otras posibilidades de mundo) y ontológicas (presentando otras posibilidades del ser.) Pero hacer investigación sobre teatro implica realizar una búsqueda introspectiva (que ve hacia el interior de uno mismo) y extrovertida (sus resultados se muestran abiertamente al otro.) Es mucho más que hacer talleres (espacios de manufactura o maquila artística o artesanal que permiten un aprendizaje práctico), seminarios (espacios de diálogo donde, sin llegar a la práctica, se propicia un aprendizaje teórico) o laboratorios (espacios donde se experimenta o se pone en discusión práctica un conocimiento teórico, obteniendo entonces un aprendizaje más significativo.) Entonces, reflexionar acerca del teatro se vuelve un viaje muy especial... En medio de un océano oscuro, picado por una tormenta de incertidumbres, el actor-investigador es iluminado por un relámpago de luz que le descubre las puertas de un territorio nuevo. Inseguro, tiene que escoger alguna puerta de entrada al intrincado laberinto que significará la búsqueda de un misterioso tesoro cuya naturaleza quizá apenas intuye.

Como todos sabemos, los primeros pasos son los de la observación y, enseguida, la reflexión. Reflexionar es tratar de incorporar el nuevo territorio al mapa de lo ya conocido. Ha bastado una apariencia de sentido para que el actor-investigador decidiera el camino a seguir. Para el actor-investigador no hacen falta muchas señales, mientras su intuición lo lleve por senderos persuasivos, a veces más bien bellos que concretos o específicos. Conforme avanza, el actor-investigador se pierde entre las engañosas aguas de su intuición y los duros senderos de la realidad. Ve intrigantes puertas que tratan de seducirlo pero que no necesariamente lo llevan a alguna parte, árboles tristes invitándolo a andarse por las ramas pero sin ofrecerle frutos, muros desafiantes proponiéndole escalar alto, a veces muy alto en algún tema de interés, pero sin adelantarlo significativamente en su verdadera investigación. Navegando a través de su formación profesional, entre hallazgos y extravíos 
aprende en algún momento que su misión primordial es darle vida a la palabra del Otro, que ésa es la barca que intenta llegar al buen puerto y que él es el capitán. De vez en cuando, el actor encuentra casas de descanso en donde puede preguntar, preguntarse y comenzar a recibir respuestas, alguna le dice que va por buen camino, otra lo confunde un poco, una más lo hace sentirse perdido. En esos momentos podrá regresar un poco sobre sus pasos, recapitular para retomar el sendero, o abandonarlo todo y volver a la oscuridad de donde vino, en vez de seguirse aventurando a la búsqueda de algo que no acaba de comprender, ni de justificar, en el relato de su existencia.

Con estas reflexiones más elaboradas, el actor-investigador paciente, constante, accede al nivel de la crítica. Ahí hay alguna pequeña torre formada con los escalones de sus primeros y parciales hallazgos. No importa el tamaño, sino que desde esa breve estatura se pueda asomar un poco más allá, con algo de agudeza, para entonces continuar con menos miedos, con alguna pequeña nueva hipótesis en medio de la lluvia de incertidumbres que no cederá. Un actor-investigador que pueda criticarse a sí mismo convertirá la nave frágil de un poema apenas leído en la otra poderosa de una partitura en proceso de interpretación, que le ayudará a avanzar más rápidamente, con menos tropiezos y con algunas nociones conceptuales a modo de paraguas. Se convierte en una máquina que chapotea mucho pero que, sin duda, se mueve. Ahora sus hallazgos no sólo sirven de puertas y escalones, también son ventanas que asoman a otras rutas, quizá más sobre la tierra, mientras agrega a su equipamiento personal motores, velámenes y hélices que, entre todos, parecen fragmentos de un cascarón que poco a poco se va construyendo. El constructo-aparato de conocimientos es todavía tan frágil que puede romperse en cualquier momento, pero un decidido actor-investigador ya está lo suficientemente sumido en su búsqueda personal como para querer regresar, y se da cuenta de que la aventura consiste, precisamente, en encontrarse a sí mismo a través del poema.

El actor-investigador está ya en el círculo de la teoría. Aquí podría instalarse cómodamente, dedicándose a la contemplación más pura, dando vueltas indefinidamente, tratando al poema como a las cuentas del rosario, creyendo haber llegado a algún lugar cuando en realidad se ha extraviado. Casi está a punto de llegar, pero no se da cuenta porque tiene que mirar a otro lado después de haberse acostumbrado a un solo sentido. Si lo logra y toma distancia y da el salto-cambio de actitud, entrará a la torre más alta, la de la 
filosofía. La suma de sus poderes, es decir, sus observaciones, reflexiones, críticas y conocimientos debe ahora ser fundida como pepitas de oro, para que pueda forjarse como la llave de la cámara de la verdad. Tan cerca y tan lejos de la verdad, el actor-investigador representa, actúa integrando entonces el conocimiento a su habilidad. Se sentirá eufórico, con el júbilo de un arlequín. El panorama parece tan claro como una ley, tan abierto como un principio... pero la verdad es tan pequeña y tan efímera como la luz de una pequeña lámpara de aceite, y el arte tan discutible, que sólo habrá de iluminar brevemente al actorinvestigador apenas para que le dé tiempo de escribir algo de lo que haya comprendido y luego, en esa misma torre, renazca, rompiendo su viejo cascarón, con nuevas dudas en el éter de la filosofía. Toda esta descripción del proceso de lectura-investigación particular en los usos y costumbres del actor teatral evoca una brumosa imagen onírica, similar tanto a una espiral como a un laberinto.

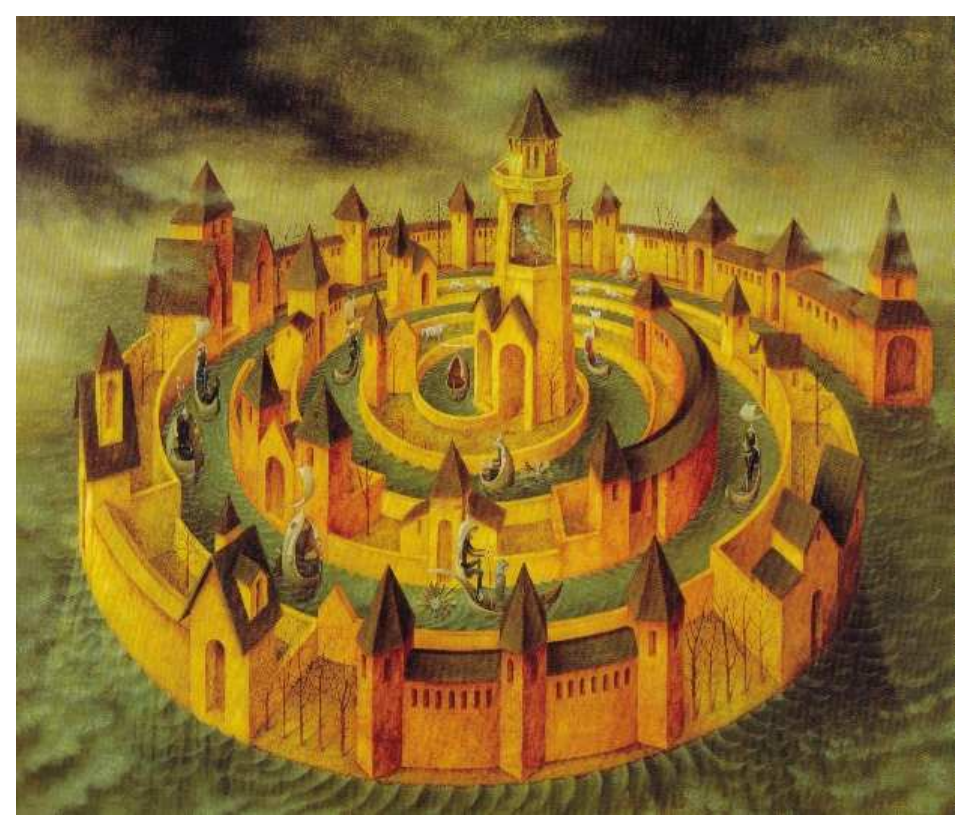

El laberinto, de Remedios Varo.

Veamos qué tanto esta metáfora nos puede ser de utilidad.

Según diversos epistemólogos de las ciencias sociales, una de las estrategias de escritura más útiles para pensar los problemas sociales [como el fenómeno teatral] es la metáfora. Y una de las metáforas más ricas para referirse al espacio habitable [como el universo teatral] es el laberinto. (Lauro Zavala, Posmodernidad, vida cotidiana y escritura, 61.) 
Uno de los defectos más señalados en los teatristas al momento de discutir es nuestra proclividad a disgregarnos, esto es, a la falta de rigor argumentativo, a "andarnos por las ramas". Aquí intentaremos hacer del defecto una oportunidad, partiendo de la aceptación común de que el campo de estudios teatral es un "laberinto de laberintos", es decir, una red de relaciones interminables y virtuales, con más de una entrada y más de una solución posibles, donde, de hecho, cada entrada puede ser también una salida (y al revés). Los presupuestos para esta consideración son los siguientes:

El estudio del teatro son muchas disciplinas en una

La investigación teatral es un espacio babélico

La ciencia teatral es un ámbito conjetural

La teatrología es un proyecto interminable

(Paráfrasis a partir de "La ciudad como laberinto rizomático", en Posmodernidad, vida cotidiana y escritura, 65.)

Como el teatro es espacio idóneo de lo imaginario, este laberinto no tiene una única verdad ni una única solución, no tiene principio ni fin. Es el espacio virtual (el ámbito de estudio) de la virtualidad (el arte) donde todo es posible. Como ocurre con el flujo de la conciencia, cualquier punto se puede conectar con cualquier otro, incluso de modo sincrónico con otros. Sólo en la paradoja de este caos lógico podemos entender el teatro y, por lo tanto, desarrollar una reflexión sobre el actor. Por lo tanto, en este apartado se intenta proponer, más que un modelo innovador, un enfoque particular de acercamiento teórico-práctico a la investigación teatral. Para ello, tomaremos como objeto de análisis la figura, participación y funciones del actor teatral en la generación del discurso escénico, considerando una vertiente teatrológica autorreferencial (derivada del rizoma de Deleuze y Guattari) que considere su propia perspectiva como sujeto investigador, esto es una "propioceptiva rizomática".

\section{El análisis rizomático aplicado a la actuación como investigación}

Una de las propuestas más refrescantes en cuanto a modos de pensamiento surgidas durante el siglo XX se la debemos a Gilles Deleuze, quien junto con Félix Guattari -entre otrosrompe con las fronteras de la linguiística para invadir los campos de la filosofía (y los de la psicología, la sociología, las artes, la literatura, etc.), desarrollando así el método rizomático. Veamos por qué este modelo de análisis (o, en palabras de Deleuze y Guattari, 
esquizoanálisis) es ideal para un proyecto comparatista como el nuestro. A partir del libro Mil mesetas (1979), Deleuze y Guattari (a quienes desde ahora citaremos como D y G) proponen su modo de practicar un análisis del mundo, comparando su modelo con un tubérculo, es decir, con un tipo de vegetal que crece libre y se interrelaciona subterráneamente con su entorno.

El rizoma no tiene raíces. El rizoma es un tallo horizontal y subterráneo. El rizoma posee muy diversas formas: una extensión superficial ramificada en multiplicidad de sentidos, hasta concreciones en bulbos y tubérculos... Lo que pretende el método del rizoma es crear multiplicidades, conectarse con diversos planos, hablar de diversas maneras, desterritorializar conceptos (aventura del pensamiento que tiende a lo inédito), reterritorializar otros (reconquista del entendimiento que funda territorios en la realidad que siempre se escapa). (Paulina López-Portillo 1999, El horror: 37.)

Respecto a las virtudes del método rizomático, dice López-Portillo:

El método rizomático no pretende imitar al mundo o reflejarlo, describirlo, crear un discurso científico o basarse en una sola línea de análisis al fundarse en una raíz... Los hilos que componen el texto no se remiten todos a la voluntad; hay fuerzas inconscientes, culturales, colectivas, que hablan... No hay modelo-idea a seguir. (López Portillo 1999: 37.)

Podemos, por tanto, afirmar que este método permite algunas libertades en cuanto al tratamiento del tema, la metodología de investigación y el punto de vista crítico. Aunque el método, por principio, no tendría principios, de Mil Mesetas hemos tomado los siguientes:

$1^{\mathrm{o}}$ y $2^{\mathrm{o}}$ Principios de conexión y heterogeneidad: cualquier punto del rizoma puede ser conectado con cualquier otro, y debe serlo.

$3^{\circ}$ Principio de multiplicidad: sólo cuando lo múltiple es tratado efectivamente como sustantivo, multiplicidad, deja de tener relación con lo Uno como sujeto o como objeto, como realidad natural o espiritual, como imagen y mundo.

$4^{\circ}$ Principio de ruptura asignificante: frente a los cortes excesivamente significantes que separan las estructuras o atraviesan una. Un rizoma puede ser roto, interrumpido en cualquier parte, pero siempre recomienza según ésta o aquella de sus líneas, y según otras. [...] Lo bueno y lo malo sólo pueden ser el producto de una relación activa y temporal, a recomenzar. [...] El rizoma es una antigenealogía. Igual ocurre con el libro y el mundo: el libro no es una imagen del mundo, según una creencia muy arraigada. Hace rizoma con el mundo, hay una evolución aparalela del libro y el mundo, el libro asegura la desterritorialización del mundo, pero el mundo efectúa una reterritorialización del libro, que a su vez se desterritorializa en sí mismo en el mundo (si puede y es capaz).

$5^{\circ}$ y $6^{\circ}$ Principio de cartografía y de calcomanía: un rizoma no responde a ningún modelo estructural o generativo. (D y G 1979: 13-17.) 
De lo anterior deducimos el carácter interdisciplinario de nuestra metodología. Otro aspecto importante está en que: “... el libro no es una imagen del mundo” (D y G 1979: 16.) Es decir, que un texto, al menos desde el punto de vista rizomático, no debería pretender representar un objeto real. Reflejar, pues, como una calcomanía (un calco), la realidad, según el método rizomático, no es una capacidad verdadera del libro. Un libro, entonces, debería ser: “... mapa y no calco. [Hay que] Hacer el mapa y no el calco”. (D y G 1979: 17.) Efectivamente, escribir un texto de tipo rizoma implica aceptar que la verdad es efímera, cambiante, como un mapa en constante proceso de ser dibujado pero nunca acabado (como la representación teatral).

... el rizoma sólo está hecho de líneas [vértices temáticos en cualquier dirección]... el rizoma está relacionado con un mapa que debe ser producido, construido, siempre desmontable, conectable, alterable, modificable, con múltiples entradas y salidas, con sus líneas de fuga [libertad de deconstrucción e interrelación temáticas]. (D y G 1979: 25, 26.)

El método rizomático propone también dejar de ver al autor como el agente de enunciación de un discurso personal. El autor no existe como sujeto de enunciación sino como el agente de un deseo del subconsciente colectivo. El método rizomático propone voltear a ver el texto más que como un producto material, como un acontecimiento: "El sujeto no existe como tal, como una realidad preliminar; lo que existe es el acontecimiento" (López-Portillo 1999: 35. ${ }^{280}$ La emancipación del texto del autor enmarca nuevos criterios para juzgar lo que conocemos como realidad. No necesariamente todo lo verdadero es real. La realidad es incognoscible, ${ }^{281}$ y juzgamos como verdadero aquello que, experimentalmente, se presenta como una continuidad. Las leyes de la ciencia son estadísticas de resultados constantes en condiciones continuas. Aportaciones de la teoría de la relatividad y de la física cuántica plantean que nuestro conocimiento científico de la realidad es vulnerable, es decir, que existen excepciones y discontinuidades en la naturaleza. Es más, es posible que las leyes naturales no sean sino una serie de asombrosas excepciones. En otras palabras, nuestro

\footnotetext{
280 Lyotard (1986) es de los primeros teóricos en introducir acontecimiento para referirse a los nuevos modelos expresivos de lo que comúnmente llamaríamos "texto". Para los semiólogos, todo lo legible por cualquier modo seguirá llamándose "texto", aún tratándose de sistemas de signos no lingüísticos.

281 “... una ciencia se localiza en un campo del saber que no absorbe, en una formación que es de por sí objeto de saber y no de ciencia”, dice Deleuze. (en su libro de 1987, Foucault: 45.)
} 
juicio de verdad es algo relativo ${ }^{282}$ e incierto. ${ }^{283}$ Quizá por esto, es reciente que los investigadores occidentales se interesen tanto por el caos y la incertidumbre, algo que los actores han sabido desde siempre al repasar por sus labios y su piel un vasto universo de infinitos mundos posibles. La condición posmoderna implica un reconocimiento de que nuestras grandes verdades históricas no son sino grandes mitos, es decir, narraciones legitimantes. Jean Francois Lyotard (1986, La posmodernidad explicada a los niños) llama a estos grandes mitos grands récits, grandes relatos o macrorrelatos, a los cuales opone el petit récit, el pequeño relato o microrrelato. ${ }^{284}$ Los grandes relatos o macrorrelatos son las grandes ideas en las que se apoyan las instituciones y prácticas sociales, políticas y culturales de la civilización occidental. Un pequeño relato es un discurso parcial, fragmentario y autorreferente, sin pretensiones totalitarias; una pequeña verdad que reconoce un origen ficticio, es decir, en la especulación. ${ }^{285}$ Cuando ensaya, un actor escribe en el aire pequeños relatos. Sus ensayos no registrados en el papel son precisamente como una serie de pequeños relatos ensayísticos, o microrrelatos, siguiendo el método rizomático, el cual:

... contiene a la vez una y varias verdades simultáneas, como un sistema de desconstrucción recursiva de sus propias condiciones de posibilidad. Este sistema de verdad da lugar a la indeterminación... La indeterminación permite, precisamente, la coexistencia de sistemas de verdad cerrados, y sistemas abiertos a la ambigüedad y la contradicción. Se trata de un metasistema constituido a partir de varios sistemas de paradojas que se apoyan en el principio de una incertidumbre que sólo se resuelve (si es esto lo que el lector requiere) en cada acto de interpretación. (Zavala 1998: 13.)

Este método revalora el impulso creativo de la especulación (incluyamos en ella a la intuición) en los procesos de conocimiento. Los grandes mitos surgieron de una especulación y siempre ofrecieron una explicación del mundo. Sin embargo, a diferencia de los grandes relatos, los pequeños relatos (como el rizoma) especulan asumiendo la

\footnotetext{
282 “... la verdad es un concepto polisémico que nos recuerda que todo sentido es contextual, y por esta razón se produce en función de un espacio de referencialidad en el cual tiene validez propia". (Zavala 1998: 11.)

283 "El saber no es ciencia ni siquiera conocimiento". (Deleuze 1987: 45 y 46.)

${ }^{284}$ Aunque Enrique Lynch traduce grand récit como "meta-relato" (en la edición hispana de Editorial Gedisa, junio de 1996), creemos que es más adecuado usar "gran relato", para evitar confusiones conceptuales asociadas a la narrativa. Alfredo Michel, con la misma intención aclaratoria, nos ha propuesto usar "macrorrelato" y "microrrelato".

285 “... toda verdad es una construcción ficcional que implica autorreferencialmente sus propias condiciones de posibilidad". (Zavala 1998: 12.)
} 
imposibilidad del conocimiento. Especular permite asomarse de alguna manera a aquello que por el solo razonamiento lógico no se alcanza a vislumbrar. Especular es hacer ficción de la teoría, una ficción teórica. Especular qué es el teatro y cómo poner en escena una obra es lo que hace un actor cada vez que lee y relee un texto (poético, narrativo, periodístico, científico o incluso dramático). El fenómeno teatral nos enseña la pertinencia de imaginar diálogos inéditos que comuniquen lo incomunicable para, entonces, aprender más. No somos, sin embargo, los primeros en buscar y/o aplicar la posmodernidad fuera de su supuesto espacio original. Recordemos, por ejemplo, la lectura que Michel Foucault hace del Quijote de Cervantes y de Las Meninas de Velásquez en Las palabras y las cosas (1966.) Anota Jean Francois Lyotard sobre los autores en la posmodernidad: "El artista y el escritor trabajan sin reglas y para establecer las reglas de aquello que habrá sido hecho" (Lyotard 1986: 25). El texto que se puede generar con el método rizomático es un texto de lectura nómada, es decir, de una multiplicidad de lecturas, donde cada bulbo o tubérculo, cada ensayo, cada ficción teórica, o literaria, se pueda conectar horizontalmente con otro.

... a diferencia de los árboles o de sus raíces, el rizoma conecta cualquier punto con otro punto cualquiera, cada uno de sus rasgos no remite necesariamente a rasgos de la misma naturaleza; el rizoma pone en juego regímenes de signos muy distintos [inter, multi y transdisciplinariedad $]^{286}$ e incluso estados de no-signos... (D y G 1979: 25.)

Es decir, que: "contrariamente a los sistemas centrados (incluso policentrados), de comunicación jerárquica y de uniones preestablecidas, el rizoma es un sistema acentrado, no jerárquico y no significante, sin General, sin memoria organizadora o autómata central [sin compromiso temático definitivo], definido únicamente por una circulación de estados [variaciones de lectura y escritura sugeridas por el texto mismo].” (D y G 1979: 25, 26.) No hay, por tanto, un tema absolutista, aunque sí ha de buscarse un pre-texto, un detonante, para justificar el trabajo. Conviene que ese pretexto sea una inquietud o curiosidad por reterritorializar (resignificar provisionalmente, mientras la curiosidad produzca líneas de fuga, es decir, nuevas posibilidades de significación) las relaciones que hay entre las manifestaciones escénico-espectaculares y literarias (especialmente dramáticas, etc.) del fenómeno estético llamado teatro. Para nosotros, en resumen, la propuesta del método rizomático implica una posibilidad para debatir con libertad que nos invita a la creatividad.

\footnotetext{
${ }^{286}$ Este aspecto nos parece fundamental para el estudio de un sistema de signos combinados como es el teatro.
} 
El cuestionarnos qué tanto puede aprovecharse del espíritu del método rizomático para un estudio teatrológico es algo que nos ocupa en nuestra propia investigación. No se trata de un seguimiento a pie juntillas, es decir, de la aplicación ejemplar de un método conocido, sino de la recuperación de su carácter abierto (estrictamente en tanto constante elaboración), dialogal (ínter, multi y transdisciplinar) y autorreferencial (donde el actor pueda hablar de sí mismo y su quehacer), para desarrollar un esquema teórico-práctico tan específico como un proceso integral de puesta en escena: "un oficio que, en el momento en que se ejecuta, desaparece" (Barba: La canoa de papel 22.) De ahí que hemos titulado provisionalmente a nuestro modo de trabajo (como plan de consistencia para esta investigación particular): escenoma.

\section{El método escenoma}

Ya que hemos establecido la pertinencia de un actor-investigador como lector especializado competente para estudiar a profundis un texto como El príncipe constante de Calderón, y habiendo recorrido en su análisis el formalismo aristotélico (en su sentido más amplio), la semiología, la antropología teatral y el método rizomático, podemos ahora denominar escenoma a este modo específico de investigación.

\section{El escenoma es el método particular de investigación creativa por el que un actor teatral desarrolla un profundo proceso de lectura analítica sobre un texto dramático y donde como lector especializado adopta un papel explícitamente activo para la concreción de la intentio dramatúrgica fundamental que es la representación escénica mediante la construcción de una interpretación crítica con recursos tanto filológicos como artísticos avanzados.}

Actuar, en tanto que interpretar diferentes roles, es lo que de hecho todos hacemos, mediante nuestras conductas, dependiendo del escenario social que nos toque atravesar. La actuación teatral es singular por concentrar toda la capacidad actoral del individuo en el espacio-tiempo concreto de la representación escénica. Aquí buscamos una teoría del actor 
que parta de la subjetividad del mismo, o sea, de su persona, lo cual, en un campo tan complejo como el estudio del signo teatral $^{287}$, no es de ninguna manera impertinente.

Reflexionar sobre la actuación es siempre un preguntar continuo sobre el enigma de ese devenir humano que todavía llamamos teatro y que es un incesante preguntar sobre el enigma del teatro que todavía llamamos acontecer humano. (Luis de Tavira 1999, El espectáculo invisible: 11 .)

No se propone una nueva teoría ni marco teórico consolidado, sino un boceto para propiciar lecturas analíticas e interpretaciones escénicas alternativas que estimulen la actividad crítica del actor tanto en el plano de la creación artística como en el de la investigación.

El teatro no es sólo espejo de la realidad, sino laboratorio y crisol de nuevas vivencias de lo real. (Leñero 2003. 230.)

Un escenoma es el plan de consistencia de una investigación teórico-práctica en el ámbito de las artes escénicas, concentrada específicamente en hacer en cada lectura y representación una descripción detallada de la participación del actor en la generación del sentido teatral, desde su más profunda subjetividad en el escenario mismo, en una categoría propioceptiva.

La categoría propioceptiva ubica la posición del ser vivo en su medio. Esta posición revela cómo se siente y reacciona en su medio el ser vivo. [...] La categoría propioceptiva, o categoría tímica, indica esa percepción que el ser humano se hace de su cuerpo. (Gabriel Weisz Carrington 1996, "Personificaciones somáticas”, en Poligrafías. Número 1, 1996. 66.)

Lo que proponemos, dicho en otras palabras, es poner en papel lo que Weisz denominaría una historia corporal.

El cuerpo se convierte en una superficie y una interioridad semiótica que procesa los significados mediante una capacidad de sentir y de conocer. (Weisz 1996, 66.)

El cuerpo de un actor, en tanto que instrumento de comunicación, puede compartir un conocimiento potenciado que todos mantenemos latente o a un nivel elemental.

\footnotetext{
${ }^{287}$ No intentaremos aquí precisar la naturaleza del signo teatral, sino ubicar en él la participación del actor y su quehacer.
} 
El cuerpo es el espacio donde se escenifican textos de muy diversa naturaleza y donde se reúnen esencias y humores antitéticos. (Weisz 1996, 80.)

La historia corporal de un actor tiene especificidades (textos o discursos, esencias o funciones, humores o ideologías-axiologías, etc.) que vale la pena recuperar. Esas especificidades constituirán nuestro escenoma. Ahora bien, en tanto que la experiencia performativa del actor obedece a un acontecer efímero, el escenoma ha de sustentarse como una estrategia propioceptiva dinámica que sirva para reflexionar acerca del actor desde el actor mismo, para después poder convertirse en un modelo teórico. Una vez acotada la naturaleza propioceptiva de la investigación actoral experimental, es necesario contextualizar su carácter dinámico. Este carácter emerge del cuerpo del actor, que la antropología teatral estudia como un comportamiento, pero no como el cruce de funciones orgánicas que crean un significado escénico y que requieren, por lo tanto, de otra aproximación. Gabriel Weisz Carrington propone visualizar el cuerpo como una construcción teórica, al modo de Deleuze y Guattari, para utilizarlo como herramienta de conocimiento.

La biosemiótica actúa como un ámbito donde se articulan el discurso biológico, el lingüístico y el del inconsciente. [...] la biosemiótica relaciona el conjunto de conductas y discursos corporales como representación de textos somáticos. La teoría biosemiótica reúne el cuerpo con el lenguaje. (Dioses de la peste, 23.)

El teórico plantea que el entorno cultural de un individuo puede alterar su conducta fisiológica, como sucede con el poder sugestivo de un curandero que, mediante palabras mágicas, es capaz de aliviar un cáncer, o bien, como en el caso del actor que, a través de un poema, no sólo se conmueve hasta las lágrimas, como si la tragedia le hubiera ocurrido a él, sino que todo su cuerpo tiende a enrojecerse, temblar de un inexistente frío, o sudar como si lo estuvieran torturando realmente, ${ }^{288}$ o incluso generar feromonas como si su amor por el compañero (a) de escena fuese verdadero. El actor es, además, capaz de llevar esta sugestión de su propio cuerpo al cuerpo ajeno del espectador, compartiendo así su texto corporal y alterando la fisiología de todos los asistentes al evento escénico.

\footnotetext{
${ }^{288}$ Pensemos en la glosadísima actuación de Riszard Cieslak en El príncipe constante, de Calderón, bajo la dirección de Jerzy Grotowski.
} 
El cuerpo constituye un lenguaje en el sentido de que abarca varios sistemas de señales diferenciadas. Pero también nos remite al texto, donde no hay una parte del mismo que pueda funcionar independientemente de las demás. Es un sistema imbricado en sí mismo y en los ambientes en que se encuentra. (Dioses de la peste, 24.)

Al ubicar al texto como manifestación definitoria del entorno cultural, Weisz observa que el texto puede operar transformaciones en el cuerpo, y el cuerpo a su vez en el texto, e incluso el cuerpo genera un texto propio. De ahí que idee su biosemiótica como una hermenéutica cuya entidad principal sea el cuerpo. Lo que nos interesa del enfoque biosemiótico para nuestro análisis escenómico es el reconocimiento de las cualidades del actor para modificar su entorno cultural mediante su instrumento y su obra. Como sabemos, tanto el instrumento como la obra creativa del actor confluyen en un mismo elemento que es su cuerpo. Mediante su cuerpo y en su cuerpo, el actor construye el discurso ficcional de una fantasía con grandes potenciales somáticos.

[...] la sustancia fantástica tiene la propiedad de convertir el texto en un instrumento para producir turbulencia. La proyección consciente o inconsciente del cuerpo sobre el objeto creado activa un ambiente inquietante, pues en nuestra sociedad se prefiere ocultar e inmovilizar el cuerpo. (Dioses de la peste, 60.)

El paso lógico es recuperar la experiencia del cuerpo actoral para entender los procesos que articulan su discurso creativo. Como veremos en este trabajo, una de las teorías contemporáneas que permiten desplegar un análisis complejo con una base corporal es el rizoma de Deleuze y Guattari. Ellos sugieren tomar el cuerpo como una máquina de guerra crítica-hermenéutica para estudiar la cultura y sus fenómenos, como lo son la literatura y el espectáculo. Un fenómeno cultural muy específico es el teatro (literatura + espectáculo). Ludwik Margules, director escénico polaco-mexicano, coincide con el punto de vista de Deleuze y Guattari sobre ver en la corporalidad el mediador crítico para desnudar la cultura. Margules, desde luego, lo hace desde una posición estético-creativa. Margules usa el cuerpo del actor para introducir un discurso artístico en el entorno cultural. Su análisis puede seguirse desde el trabajo previo al montaje, esto es, desde la conceptualización y selección de una obra dramática, su estudio, contextualización, lectura con los actores, ensayos, montaje y producción; hasta la retroalimentación con el público llano y especializado, incluyendo al equipo mismo de trabajo en su experiencia representacional, 
de la primera a la última función, y aun las reflexiones a posteriori (Todo eso es lo que abarca una lectura actoral integral.) Pero además del análisis que el teatro hace sobre la sociedad, está la impronta crítica de ser su espejo y un medio de provocación para inducir su evolución. Para lograr esto, Rodolfo Obregón afirma que Margules busca...

Un actor imaginativo y a la vez poseedor de una técnica muy sólida. No le interesa el actor que se oculta en su técnica para no tocarse a sí mismo, sino aquel que mediante la imaginación logra transgredir su técnica y descubrir lo que no sabe de sí mismo. (En Carlos Paul, "Definen a Margules como 'poeta de la complejidad", en La Jornada, viernes 6 de agosto de 2004. Cultura $4^{\mathrm{a}}$.)

En tanto que medio de provocación, el actor es, efectivamente, una máquina de guerra, tanto más eficiente cuanto mejor entrenada, dispuesta y guarnecida.

Para Margules es imperativo que el actor no utilice ninguna estratagema que le permita descubrir cualquier "comodidad" escénica. Ni en los medios tonos de la luz, ni en el maquillaje, ni en la distancia con el espectador. El actor está tan desprovisto de cualquiera de estas herramientas, que no tiene otra elección que acudir a la verdad escénica. Una verdad que debe sostenerse puntualmente ya que el margen para enflaquecer cualquier expresión actoral puede ser descubierta de inmediato. (Alfredo Vargas, "Los Justos", en Paso de Gato, año 2, número 7, marzo-abril de 2003, 51.)

Un escenoma sería entonces una red de conocimientos y experiencias; tan compleja como la comprensión del signo teatral, pero tan específica como el estudio directo del fenómeno escénico; en de-construcción constante, es decir, rehaciéndose siempre, pero jamás sin disolverse del todo; como una alfombra de musgo que genera una intrincada superficie inestable; más que efímera, mutable; relativamente consistente, pero no tan dura como el roble; una alfombra de musgo que reverdece de vez en cuando, cuando una nueva lluvia de ideas aparece, refrescante o peligrosa, para alimentarla.

This green plot shall be our stage. (Shakespeare. A Midsummer Night's Dream. III, i.)

Sobre esta alfombra de musgo queremos que camine descalzo el actor. Después de todo, sólo él, que re-significa la materia, el tiempo y el espacio, podría caminar por aquí. Descalzo quiere decir sin los duros zapatos que lo apoyan sobre el escenario con juicios previos sobre cómo pisar, cómo moverse, cómo hablar, cómo predisponerse 
psicológicamente, qué hacer, en fin: cómo actuar. Descalzo, pero no desnudo. Lo queremos vestido con su ropa teatral, con su personaje, para observarlo así, mientras carga con su papel (su lectura especializada), y hacerle explicar, sin prejuicios teóricos, lo que aquí y ahora, sobre esta alfombra de musgo, está pensando, sintiendo, haciendo y dejando de hacer: Para escuchar su experiencia recuperada.

\section{El ensayo (escrito) teatral (actoral)}

Las reflexiones humanísticas requieren tomar una forma perdurable si quieren ser mejor compartidas a lo largo del tiempo, incluso si se refieren a ese juego efímero que es la representación teatral. Pareciera que las ideas piden, suplicantes, ser escritas. "A batallas de ideas, campos de papel”, dice Federico Patán. ${ }^{289}$ Como en las humanidades la diversidad de los puntos de vista es la que enriquece al conocimiento, la forma más recurrente para escribir sobre la literatura es el ensayo, porque -como todos sabemos- el ensayo es la intencionada puesta en papel de un punto de vista en diálogo con otras posturas. Habría que aclarar que la forma más recurrente para escribir sobre la literatura es la literatura misma, en su sentido más amplio, más allá del ensayo, como lo demuestran los clásicos poéticos, narrativos y dramáticos en sus momentos, precisamente, ensayísticos meta-literarios ${ }^{290}$.

El ensayo es la consecuencia de ensayar un punto de vista mediante una forma textual. Es una apuesta sobre papel en donde ningún lector debería de perder. El contenido de un ensayo puede, eventualmente, tomar forma de verso o prosa, narrativa o drama, apunte, tesis o tratado, y es por ello que podemos hablar tanto de ensayos, en el estricto sentido de una redacción argumentativa, como de textos ensayísticos, es decir, textos de naturaleza originalmente distinta a la argumentativa -en principio o en apariencia- pero que ensayan el punto de vista del autor sobre algún tema. Haciendo memoria, veremos cómo el ensayo permea los otros géneros literarios y cómo éstos se trasminan en él a su vez. El ensayo no está definido por una forma específica, sino por sus posibilidades abiertas e híbridas para argumentar. Sin embargo, lo común a los ensayos, como todos sabemos, es plantear persuasivamente una perspectiva sobre cualquier tema sin pretender agotar al mismo, utilizando para ello la capacidad argumentativa del autor y su imaginación.

\footnotetext{
289 2001. Ángela o las arquitecturas abandonadas. 18.

290 “Doxales o gnómicos”, se les llama también (Luz Aurora Pimentel 1998. El relato en perspectiva. 162.)
} 
Considerando su vocación dialogal, la estructura estándar de un ensayo consiste, básicamente, de: tesis o perspectiva, argumentación y conclusión. Hay que considerar también la dimensión de la imaginación en la creación de un ensayo, recurso por el cual el texto adquiere identidad propia o estilo. Una verdad demostrada puede no ser interesante, o incluso no convincente, si la forma de presentarse no es imaginativa (bella, creativa, graciosa.) Por contraste, la más grande mentira es bienvenida por venir, justamente, adornada por la imaginación. El sabor a originalidad o a trasgresión, propio de la obra artística, es fruto de esta imaginación. Así, podemos decir que en el ensayo se funde una naturaleza fundamentalmente crítica, que es racional, con otra estética, que es básicamente imaginativa. Tal vez la naturaleza imaginativa (entendiéndola como bella, creativa, graciosa) es la que más distingue al ensayo de otros textos argumentativos (el científico, por ejemplo, que prioriza el rigor objetivo-demostrativo por encima de las posibilidades subjetivas de belleza y gracia.) El ensayo literario es un texto de creación.

La verdad encuentra en el ensayo múltiples espejos que le descubren, cada vez más, una fragilidad que antes parecía no tener. Pero en el ensayo, también, la verdad puede parecer más verdadera (la literatura es a veces más verosímil que la realidad.) Si vida y arte no se reconcilian, no importa, porque en el contraste podemos contemplar, con mayor claridad, las dos caras humanas del mundo, es decir, la que podemos ver y la que deseamos. No importa que los puntos de vista se contradigan, pues entre antagonismos cobran su existencia, igualmente, ficción y realidad. Es en ese diálogo ficción-realidad donde el ensayo se presta tan apropiadamente para el estudio de la literatura en general y para la investigación teatral en particular. Tradicionalmente, se escribe ensayo acerca del teatro en forma de crítica y análisis. Sobre el espectáculo, se suele escribir reseña y crónica, manifestando casi siempre la forma en la que la puesta en escena acertó o no en su lectura de un texto dramático original. Cada vez más estudiosos, que entienden la lectura como un acto interpretativo más amplio que las páginas de un libro, han abierto el panorama de los estudios literarios a los discursos de la pintura, del cine, del cómic y -afortunadamente- del fenómeno escénico, desarrollando así la interdisciplinariedad que el estudio del teatro necesita en general, al mismo tiempo que propiciando la especificidad de la atención sobre el espectáculo en sí. 


\section{Dialogar el teatro}

Se dice que el teatro es la suma de todas las artes. Si no es así, por lo menos es uno de los medios de comunicación más complejos. Es, por lo menos, el arte que no excluye a ningún arte. Es quizá el arte más humanista. Baste recordar que en una representación teatral el trabajo de creación se da simultáneamente con el acto contemplativo del espectador y que el artista creador, el actor, es al mismo tiempo parte de la creación misma, es decir, su propia obra de arte.

Acerca del teatro dice Carmen Leñero: "La realidad señala con su presencia [la del teatro] que existe y que a la vez no existe" (2000. La luna en el pozo. 14.) Efectivamente, el teatro es un rito donde el actor es depositario de dos naturalezas: una real, que es la suya propia (que existe), y una ficticia, que es la del personaje (que no existe.) Desde este punto de vista, podemos ver que la semiología teatral es un reflejo de dos mundos, que tiene una naturaleza no unitaria, es decir, que es múltiple, polisémica. Pero el teatro es todavía más. Leñero misma, mediante un poema en su libro ya citado, sugiere que el arte teatral es una:

\section{Cadena de suplantaciones para hacer presa del sentido. (Leñero 2000: 80.)}

Esta reflexión poética ilustra la naturaleza colectiva (una cadena: poeta, dramaturgo, director, actor y personaje) y representacional (simulación de otra realidad: suplantaciones) del teatro, así como su vocación por capturar y retener la atención de un espectador (que es presa del sentido.) Leñero ilustra también el carácter polisémico del teatro (cadena de suplantaciones: sistema de signos.)

El signo teatral es múltiple, más complejo que otros signos que, incluso, le constituyen (lingüístico: palabra hablada y escrita; visual: pintura, escultura y arquitectura; musical, coreográfico; etc.), y por ello su quehacer es interdisciplinario, en necesario diálogo permanente con las otras artes (pintura, escultura, música, arquitectura), las humanidades (literatura, filosofía, historia, etc.) y hasta con las ciencias naturales (anatomía, física, óptica, acústica, kinésica, proxémica, etc.) Este diálogo es el universo formativo que ofrece el teatro a quienes lo estudian. 


\section{La fábula del ciempiés}

Parafraseando a Paulo Freire, el teatro no se enseña: se aprende. Con esto queremos decir que, como práctica artística, la manera más directa de estudiar el teatro es hacerlo. Sin embargo, la fábula del ciempiés nos recuerda cómo el gusanito se paralizaba a sí mismo al tratar de entender cómo hacía para mover cada una de sus numerosas patas, sin lograr a fin de cuentas entenderlas ni moverlas demasiado. Por otro lado, es vocación del arte teatral investigar la naturaleza humana, sus conflictos, sus historias. Pero los actores, más que pensar o cuestionar, actúan, hacen. Su ambiente natural es el de la acción. La escritura actoral es la del discurso efímero de la representación escénica, y no aquella más perdurable que rasca el papel. Por ello es que tradicionalmente los actores adolecen de método y de rigor para llevar a cabo una investigación escrita. Más que para otros humanistas, para el actor la investigación metódica es comparable a un laberinto. Sin embargo, hay actores que no sólo actúan.

También hay actores que piensan en el sentido de que se cuestionan, buscan respuestas, generan ideas y las escriben. Entonces es posible la existencia del actorinvestigador. Lleva algunos años y muchas críticas y descalificaciones entender que para realizar un trabajo como actor-investigador tiene uno que desdoblarse. No hace falta optar radicalmente entre la creación artística o la investigación académica, como algunos todavía sugieren. Se trata de una cuestión de momentos alternados. Esto es: es imposible actuar y escribir al mismo tiempo, pero se puede primero actuar, luego reflexionar y finalmente escribir sobre el arte escénico. El conocimiento que tiene el actor de sí mismo es fundamentalmente empírico. El actor huye del conocimiento teórico casi siempre, cuando no le haya aplicación práctica, de preferencia inmediata. No es que no le interese documentarse. Lee, y mucho, pero principalmente aquellos textos que le sirvan de partitura o complemento para ejercitar sus pasiones artísticas.

Cuando sentí por primera vez interés por interpretar algunos de los grandes papeles de Shakespeare, intenté sacarles partido leyendo todo lo que pudiera sobre ellos. Toda mi vida he leído vorazmente, aunque siempre he sido capaz de pasar al galope con demasiada rapidez a través de la enorme cantidad de materias a cuya digestión debería haber dedicado más tiempo. Pero creo que me las arreglé para retener una buena cantidad de información. (John Gielgud. 2001 [1991.] Interpretar a Shakespeare. 47.)

En otras palabras: El actor teatral es un filólogo empírico. 


\section{El alma del teatro}

El actor es el alma del teatro porque convierte los conflictos de la historia del hombre en acción viva, encarna las voces del imaginario cultural y crea un mundo posible, un laboratorio ritual, donde podemos contemplarnos y proyectarnos.

Le comédien est le tout du théâtre. On peut se passer de tout dans la représentation, excepté de lui. Il est la chair du spectacle, le plaisir du spectateur. (Anne Ubersfeld. 1981. L'école du spectateur. 165.)

Algunas veces se olvida que fueron los ritos teatrales los que dieron origen a las demás artes, entre ellas la literatura, y no al revés. Es decir, fue un actor el primer dramaturgo, quien acaso al cansarse de bailar representando a sus ídolos, se puso a pintar, que entonces era lo mismo que escribir. Luego, esa escritura primigenia sería representada (actuada, cantada, bailada) una y otra vez. Desde entonces, el texto dramático es asumido, fundamentalmente, como una partitura. Y esa relación entre literatura y espectáculo se restablece por medio del actor. Si bien hoy la lectura de la obra dramática puede limitarse a la apreciación literaria, todos los lectores imaginan una resolución espectacular con actores ideales. $^{291}$ Es casi imposible expresar en términos rigurosamente conceptuales, objetivamente descriptivos, el proceso creativo del actor. Su arte se despliega en complejas combinaciones de acción, diálogo, silencios, tensiones.

Muchos se quedan perplejos frente a una aparente contradicción: ¿por qué, justo en el momento en el que intentamos ir más allá del conocimiento obvio sobre el teatro, las palabras se niegan a ser científicas, claras, esculpidas en definiciones? ¿Por qué se vuelven líricas, sugestivas, emotivas, intuitivas, vuelan de una metáfora a otra y no indican directamente y sin dudas las cosas a las cuales se refieren? Esta perplejidad desemboca a menudo en una respuesta estéril; si las palabras parecen imprecisas quiere decir que también aquello de lo cual hablan es impreciso. Si son personales, quiere decir que indican algo exclusivamente personal. (Eugenio Barba. 1992. La canoa de papel. 70.)

Traducir esa dinámica en una estructura textual estable tiene que resultar en una retórica encabalgada entre la objetividad y la subjetividad. Con esas limitaciones procuraremos ahora algunas descripciones acerca del trabajo del actor en la generación del sentido escénico-teatral.

${ }^{291}$ Vid. Introducción. 


\section{La realidad del mundo y el deseo del actor}

El ejercicio de cualquier profesión se justifica por sí solo cuando logra integrar los anhelos de la infancia, el servicio a la comunidad, la satisfacción de necesidades vitales y el gozo mismo de la práctica profesional. No es imposible que un infante sueñe con ser actor de teatro, aunque casi siempre se idealice la disciplina artística con el falso adorno de la fama, el glamur y ciertos lujos de los que, a decir verdad, no goza en la vida real la mayoría de los actores teatrales. Sin embargo, a pesar de las pocas oportunidades de éxito económico (y social, dicho sea de paso), ser actor en teatro se vuelve una necesidad casi vital, orgánica. Decíamos también que ser actor de teatro no garantiza el éxito social porque, en la mayoría de los casos, la práctica es vista más como un pasatiempo que como una profesión: "No, en serio, ¿a qué te dedicas?” La pregunta tiene que ver, en el fondo, con cuánto dinero se gana mensualmente, si es suficiente para mantener una familia y si además se reporta un beneficio objetivo a la sociedad. En términos estrictos, la diversión y la reflexión que propicia el teatro no son indispensables para la sociedad y, más bien, reportan un desgaste económico importante. ¿Hacer teatro no satisface ninguna necesidad vital? No directamente. Pero el público agradece el haberle hecho reír, llorar, pensar y ver el mundo de distinta manera.

El Teatro es el arte de la utopía humana,

Que cree en la posibilidad de alterar

El curso inalterable de la historia.

(Luis de Tavira.)

Desde luego, actuar en un escenario teatral es un gozo, pero un gozo que se padece. Actuar significa llorar, sufrir de verdad las cuitas del personaje, la insatisfacción del director, la incomprensión del texto dramático, los desvelos memorizando líneas, explorando tonos verbales y gestuales, lo exhaustivo de los últimos ensayos, las incertidumbres sobre la recepción del espectador. Casi nunca el actor se cuestiona qué utilidad podrá tener todo este calvario en su vida, ni en la vida de otros. ¿Por qué entonces el gozo? Porque ser actor significa hacerse de una idiosincrasia, de unas condiciones de vida especiales, es decir: 
1.La actitud vital es la de un creador. ${ }^{292}$ La profesión actoral, si bien no es de las más remuneradas ni reconocidas, acaso sea de las más nobles, pues incluso en el ejercicio de un espectáculo pro-anarquista o pro-revolucionario, el actor no hace sino poner en discusión una serie de ideas y sentimientos, prestando para ello, de manera constructiva y plena de creatividad, su cuerpo, su mente, su persona entera.

2.Alguien con propuestas de mundo. El actor trae puntos de vista de otras épocas, lugares y/o mundos y voces imaginarias, con respuestas, soluciones, o bien, nuevos problemas o cuestionamientos que nos despiertan y arrebatan a un nuevo aquí y ahora posibles.

3.En otro tiempo chamán o sacerdote, la imagen más cercana a las facultades del actor es parecida a la de un caballero andante de nuestro tiempo, un "superhéroe", con una identidad llena de misterios y con una misión positiva en el cosmos, en un oficio donde es creador, instrumento y obra, simultáneamente. No es sorprendente que a los actores más reconocidos se les equipare con estrellas en la constelación del imaginario colectivo.

4.Porque actuar, ya sea en el teatro (como artista) o en la vida cotidiana (como actor social), siempre es mejor que no actuar.

En términos mítico-arquetípicos, el oficio del actor teatral recupera además una función casi perdida de antiguos sacerdotes, como es intermediar entre la humanidad y lo otro, lo desconocido. Ser actor -entonces- ofrece una posibilidad de comunicación con los fantasmas propios y los del subconsciente colectivo, un puente con el pasado, el futuro, otros continentes y con el más allá. Es una forma de viajar, tanto por el universo, con la ayuda de la imaginación, como hacia el interior de uno mismo, en la aventura del autoconocimiento.

\footnotetext{
${ }^{292}$ Incluso en las concepciones de Alfred Jarry y Antonin Artaud, la patafísica, la destrucción, la anarquía, la revolución, la peste y la crueldad son elaboraciones metafóricas de un desfogue catártico que, aunque agresivo y hasta intencionadamente violento, resulta creativo.
} 


\section{El trabajo de mesa}

La primera herramienta que el actor anhela en sus manos, frente a sus ojos, es su partitura, es decir, el texto dramático. Adicionalmente, el actor no evade, orientado por el director o el mismo grupo de trabajo, la revisión de otros documentos que amplíen y profundicen la comprensión de la historia, el personaje y la ideología que va a representar. No es difícil inferir que este camino laberíntico de aprendizaje abreva de la competencia que el actor desarrolle como lector en todos los sentidos, no solamente de textos literarios (narrativa, poesía, ensayo, además de drama); sino de escrituras provenientes de otras disciplinas (ciencia, periodismo, etc.), incluso de "literaturas" no siempre lingüísticas, tales como las artes visuales (como en los estudios comparatistas de Arnold Hauser, et al), el cine (tomado muy en serio desde Walter Benjamin), la arquitectura (analizada por Frederick Jameson), la moda (considerada por Roland Barthes), la gastronomía (vg a la manera de Italo Calvino), el cómic (visto por muchos como la literatura del siglo XX), etc. Más específicamente, cuando el actor lee como intérprete-ejecutante (o performer), su investigación acota el universo epistemológico al contexto de un guión.

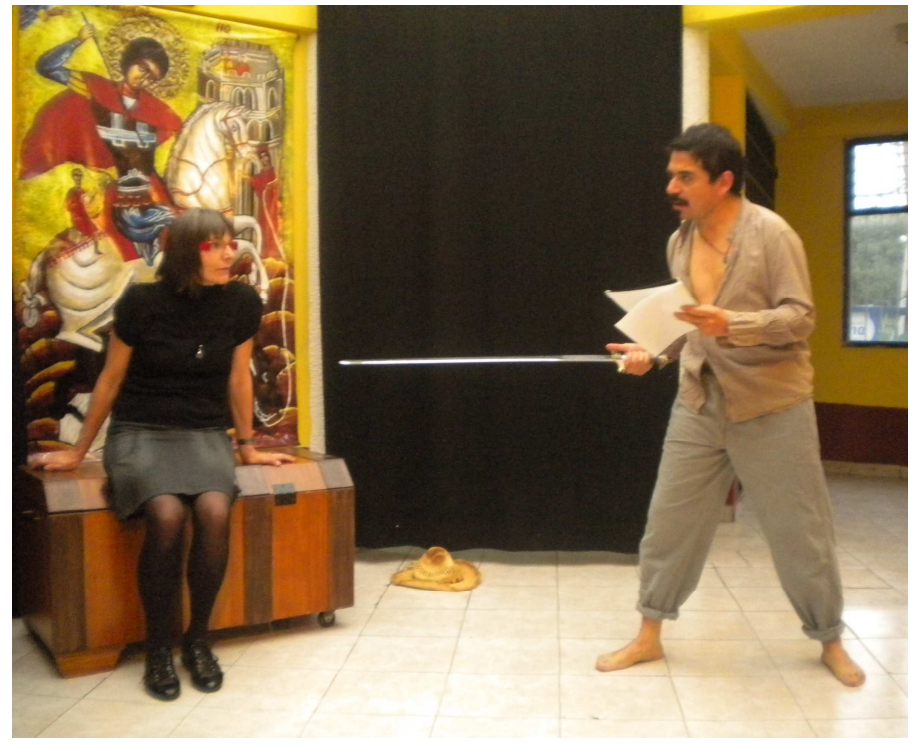

(Ensayo con libreto de El príncipe constante. Imagen junto a Christine Hüttinger.)

El guión (el texto para la representación) no siempre deriva de una obra dramática, pues puede ser un poema, un cuento, una premisa para improvisar, una imagen, etc. El actor sabe que la primera lectura es apenas el comienzo de un largo viaje consistente en relecturas del guión (lentas, en voz alta, con reiteraciones sobre distintos momentos, memorizaciones de 
voces y acciones físicas), es decir la lectura del texto; así como en la búsqueda de referentes directos e indirectos de los personajes leídos y sus situaciones (semblanza e intención del autor, contexto de producción, ideología, perspectiva estética, pragmática del habla, etc.), o sea la lectura del subtexto. Así el actor, entre denotaciones y connotaciones, entre el papel y su cuerpo, entre su persona y el personaje, hace el rol de un filólogo muy riguroso, mismo que en su análisis llega a comprometerse de manera empática con su objeto de lectura.

Para el director y para el actor, el texto es una especie de escalpelo que nos permite abrirnos a nosotros mismos, trascendernos, encontrar lo que está escondido dentro de nosotros y realizar el acto de encuentro con los demás; en otras palabras, trascender nuestra soledad. (Grotowski. Hacia un teatro pobre. 51.)

El actor debe sentarse a estudiar todo un material literario, teórico y crítico, antes de poder pararse en el escenario, en una serie de jornadas que denominamos trabajo de mesa. En estas sesiones...

1.Se determina con claridad el concepto de la puesta en escena. Esto se debe a que el texto dramático, por sí solo, no determina la naturaleza completa del espectáculo que se va a generar. Lejos de ser un defecto por carencia, es una virtud en función de las posibilidades creativas que propicia. La literatura dramática es un pre-texto para el espectáculo, un discurso que aún debe ser planeado y organizado en la mesa, para luego ser desarrollado en los ensayos y, más adelante, consolidado con cada función. En la mesa se hace la pre-producción del espectáculo (escoger el texto, estudiar su contexto cultural, seleccionar el reparto) y se toma una de las decisiones más importantes, que es la de cuál ha de ser el punto de vista a defender ante el tema a representar (y empapar al elenco con esta visión.)

2.El actor deja de leer un texto dramático literario y comienza a ejecutar una partitura de tareas escénicas. El texto dramático deja de verse como literatura, es decir, como ideas, emociones, historias y personajes puestas en papel, para verse ahora como la posibilidad real de una puesta en escena. 
Una vez realizado este trabajo, que suele ser la parte más intelectual de una puesta en escena, se pasa a conectar el papel con el resto del cuerpo del actor: voz, huesos, músculos, nervios, corazón, etc., en el proceso de los ensayos. Como consecuencia contundente de este proceso, se da una reacción virtualmente incendiaria para aquellos que sólo pueden apreciar el texto dramático como literatura encerrada en un libro: El actor comete el acto de rebeldía de liberar a esa literatura de su prisión de papel. En nuestro contexto histórico actual, donde los seres humanos nos auto-esclavizamos encadenándonos a la televisión y a la internet, el actor hace explícito que desde siempre el leer es una acción rebelde.

También somos una realidad que aún no somos, por eso sabemos que estamos en la realidad para realizarnos. En el teatro, el actor se realiza para realizar al personaje. Gracias al teatro, la humanidad se humaniza porque se personifica. Así, el mundo dependerá del teatro que realice; somos responsables del mundo que inventamos. (Luis de Tavira. El espectáculo invisible. 113.)

En la Antigüedad sólo los sacerdotes leían y escribían; siempre estuvo especialmente prohibido a los esclavos; fueron los fenicios quienes socializaron la escritura entre comerciantes. Entre griegos y romanos sólo maestros y aristócratas podían cultivarse. En el Medievo la cultura estuvo encerrada en bibliotecas y conventos, y poca gente entendía las misas en latín. La literatura se vulgariza (se hace popular) con el nacimiento de las lenguas romances. Entre el Renacimiento y el Siglo XIX (pasando por el Barroco, el Neoclasicismo, el Romanticismo, el Realismo y el Naturalismo) era visto con sospecha que una mujer leyera y/o escribiera fuera de la iglesia. El siglo $\mathrm{XX}$ es el de la verdadera Revolución del Lector. Sabiendo esto, no es extraño que en nuestro siglo XXI aún haya poderes que opriman a los pueblos en la mansa ignorancia negándoles el acceso a la educación, es decir, a su libertad. Ergo: la labor del actor como lector por horas (muchas horas en la mesa y otras tantas sobre el escenario) para su sociedad es insurgencia pura.

\section{Los ensayos (los no escritos)}

Los ensayos implican el periodo de mayor incertidumbre en un proceso de montaje. Son también el tiempo preciso para buscar y, de preferencia, hallar el mayor número posible de respuestas. Orientado por un claro concepto escénico, el actor no debería de preguntar nada, pero si lo ha de hacer éste es el momento. 
La importancia del ensayo en la vida diaria del actor consiste en que en él puede ejercerse un accionar real sobre la ética, como aquel comportamiento personal que no rinde cuentas a la colectividad sino a sí mismo. [.....] Ensayar constituye una apología del error. Su razón de ser es el error, a diferencia de la función de teatro, donde su razón es lo exacto y lo preciso. (Alberto Villareal Díaz. "Del ensayo como ensayo", en Paso de gato. México: Año 5, número 26, julio-septiembre de 2006. 50.)

Se trata de diseñar, entender, asimilar y, sobre todo, repetir diálogos, trazos y tareas (al ensayo, en francés, se le dice répétition.) Además, para el actor el ensayo es un espacio para debatir posibilidades e interactuar con sus compañeros en los juegos creativos del teatro (improvisar, sorprender, enmascarar, fingir.) Al actor le sirve repetir, probar, interactuar y discutir en los ensayos porque...

1.Los ensayos dan seguridad. Son parte integral del entrenamiento del actor, la más directamente relacionada con el proceso de la puesta en escena.

2.Los ensayos son el lugar por excelencia para experimentar, en el sentido de proponer y probar cosas nuevas.

3.Los ensayos son el lugar perfecto para aprender, memorizar, equivocar, revisar y corregir.

4.Es en los ensayos donde el actor tiene la oportunidad de proponer su punto de vista en el discurso efímero que se proyectará sobre el escenario.

Curiosamente, el actor casi no discute ni plantea su punto de vista verbalmente, sino mediante su conducta personal (entre disciplinada y rebelde) y a través del estilo personal que imprime a su personaje.

\section{Las representaciones}

Es admirable que, aunque puede haber mil razones para cancelar una función de teatro en una temporada programada, ésta casi siempre se dé. Por esta razón, el teatro debería ser visto siempre como un negocio seguro, como una profesión seria, responsable, capaz de garantizar el poder vivir de ella. Sin embargo, acaso por el desgaste físico, emocional y económico que implica una sola función, a veces parece que el actor, más que vivir del teatro, vive para él, como se ve en nuestras notas acerca de las representaciones: 
1.Las funciones deben actuarse perfectas, sin errores y, sin embargo, completamente espontáneas y abiertas a la inspiración.

2.Los momentos de inspiración son escasos, así es que es mejor toparse con ellos mientras se trabaja.

3.Es en una función donde el actor percibe, precisamente, que funciona.

4.En el momento de la representación, el actor ya no piensa: actúa. Lo que se llama línea de pensamiento, y que en la cotidianidad varía tanto como la vida real, es ahora para el actor un algoritmo preciso de tareas escénicas específicas, en un ambiente predefinido y extra-cotidiano.

Al final de una muy breve temporada teatral amateur, una estudiante suplicaba no volver a dar funciones. Había sufrido miedo, insomnio, pavor al bailar tango o a lastimarse y lastimarme con un florete que debía esgrimir en escena. Sin embargo, jamás la dominó el pánico antes, durante o después de actuar y, un semestre después, cuando se le invitó para una función especial de esa misma obra, inmediatamente aceptó. Volvió a manifestar su deseo de que fuera la última experiencia teatral en su vida pero, nuevamente, cuando se le convocó para otro proyecto ${ }^{293}$, no dudó en participar. ¿De dónde vienen estas contradicciones? El actor y profesor Héctor Téllez, del Colegio de Literatura Dramática y Teatro de la UNAM (Clidyt), hablaba de la sensación de actuar como la de un prisionero condenado a muerte que no puede, ya en la cámara de gases, escapar a su situación. No tiene más alternativa que morir. No puede resistir por mucho tiempo la respiración, así que su última bocanada es profunda... y mortal. La mayor experiencia de su vida es así, al mismo tiempo, la más honda y la más letal. Similar es la emoción que siente el actor. El actor en la representación se siente intensamente vivo e infinitamente indefenso, vulnerable, mortal en la efímera comunión del teatro. La diferencia con el condenado a la pena capital es que el actor sobrevive, y que -casi siempre- pide más de ese gas letal.

\footnotetext{
${ }^{293}$ Irene Solórzano actuó en una versión del Laboratorio de Teatro Libertad de Los monólogos de la vagina, de Eve Ensler, para conmemorar el Día Internacional de la Mujer el jueves 8 de marzo de 2007, en la Preparatoria Iztapalapa 1, junto a Artemisa Monzalvo (profesora de Lengua y Literatura), Isabel Moreno (profesora de Planeación y Organización del Estudio), Cinthia Reséndiz (alumna del plantel), Nelly Aquino (médico del Servicio de emergencias y de promoción de la salud) y Jazmín Nava (alumna.)
} 


\section{El oficio del ejecutante}

De cada profesión, el profesional algo busca que dé sentido a su práctica. En el caso del actor, éste casi nuca busca, como primera opción, una remuneración económica. Lo que buscan los ejecutantes es una especie de vida alternativa...

1.Más intensa: Porque se concentran con una sola misión cuerpo, mente y aquello que percibimos como espíritu.

2.Entregada: Porque se ofrenda ritualmente la propia vida, la de "uno", para que cobre vida "el otro".

3.Comprometida: Pues se es creador, instrumento y obra al mismo tiempo.

4.Más fugaz que la vida misma y, por lo tanto, en el plano de las experiencias sensibles, más vital.

El hombre en general, pero mucho más el actor en particular, jamás deja de actuar. Los mejores actores parecen hiperactivos por naturaleza. Buscan, se preocupan, se involucran en el pequeño gran teatro de sus mundos personales, se comprometen, juegan, se fracturan a veces, y siempre vuelven a la lucha para ganarse la vida no convencional con la que sueñan.

También somos una realidad que aún no somos, por eso sabemos que estamos en la realidad para realizarnos. En el teatro, el actor se realiza para realizar al personaje. Gracias al teatro, la humanidad se humaniza porque se personifica. Así, el mundo dependerá del teatro que realice; somos responsables del mundo que inventamos. (Luis de Tavira. 1999. El espectáculo invisible. 113.)

Los actores no se conforman con una existencia común y corriente. Los actores aspiran a vivir de modo extraordinario, y casi siempre de forma constructiva. El actor nunca deja de ser actor. Se puede decir que su ontología se desdobla en:

1.Cuando está en escena, cuando está -propiamente- actuando.

2.Si no está en escena, entonces se está preparando. El actor se prepara durante los ensayos (extendiéndolos al trabajo de mesa y a la idealización de nuevos proyectos), o bien, durante su entrenamiento personal. 


\section{El entrenamiento del actor}

El training es una parte vital de la vida de cualquier actor. Si no está representando, debe de estar entrenando.

Como el material de que dispone el actor es su propio cuerpo, debe entrenarlo para que obedezca, para que sea elástico, para que responda pasivamente a los impulsos psíquicos como si no existieran en el momento de la creación, con lo que se quiere decir que no ofrezca resistencia. (Grotowski. Hacia un teatro pobre. 220.)

El entrenamiento debe ser constante. El propósito del entrenamiento es mantener al actor en disponibilidad inmediata para el juego escénico. El entrenamiento es integral, es decir, no abarca sólo al cuerpo en términos de desarrollo físico, sino también se trata de entrenar la mente y, en su sentido más amplio, el espíritu. El actor debe tener una cultura general vasta, que le permita conectarse con sus personajes sin importar demasiado de qué contexto histórico-social provengan, para interpretarlos sin juzgarlos.

El ejercicio técnico es una ficción pedagógica que, en su rodeo por la ficción dramática, permite servirla mejor. (Jean Marie-Pradier "Eugenio Barba: El ejercicio invisible", en Carol Müller [coord.] El training del actor: 65.)

El entrenamiento es el protocolo por el cual se planea, construye y da mantenimiento a la máquina creativa que el actor percibe como su corporalidad, y que es la suma de todas sus capacidades reunidas tanto en su herencia genética (biotipo) y el contexto cultural en el cual creció como persona, como en sus experiencias de vida, su condición física general y sus prácticas cotidianas.

Los cuerpos se dejan enseñar, aprenden. En el training sucede lo mismo que en la meditación: si le dedicamos una hora diaria, no alcanzamos su objetivo, pero si le consagramos tiempo, poco a poco el cuerpo comienza a comprender. (Yoshi Oída "La estrategia del ninja", en Carol Müller [coord.] El training del actor: 95.)

Por encima de todo, el entrenamiento da seguridad al actor para todo lo que necesita hacer en escena, tanto a nivel consciente (al seguir una secuencia predeterminada, o bien, para tomar decisiones frente al espectador) como subconsciente (un organismo con reflejos casi perfectos, una máquina programada para expresarse con márgenes mínimos de error). Diferentes tipos de entrenamiento generan distintos modos de actuación y, por lo tanto, una 
mayor diversidad para la construcción de un personaje. El training permite además transmitir y hacer perdurar el intangible saber actoral.

\section{El cuerpo del actor (Respuestas a un cuestionario de Patrice Pavis)}

Un problema esencial ha sido resolver qué sucede en el cuerpo del actor, y entre este cuerpo y el espectador, para hacer del acontecimiento teatral una experiencia vital. Pavis y Barba fueron los primeros en plantear que la actuación es una condición antropológica efímera $^{294}$. Buscando una teoría del actor, Patrice Pavis (1994, El teatro y su recepción. 156 y 157) delineó una serie de observaciones desde el punto de vista del espectador, de las que se desglosan preguntas acerca del cuerpo del intérprete.

1. ¿De qué cuerpo dispone el actor antes incluso de acoger un papel?

2. ¿Qué muestra, qué oculta el cuerpo?

3. ¿Quién sostiene los hilos del cuerpo?

4. ¿Está el cuerpo centrado sobre sí mismo, conduciendo toda manifestación a un centro operacional de donde todo parte y adonde todo regresa?

5. ¿Qué es lo que, en su medio ambiente cultural, se considera un cuerpo controlado o un cuerpo "desencadenado"?

6. ¿De qué modo el cuerpo hablante y actuante del actor invita al espectador a "entrar en el baile", a adaptarse al sincronismo y a hacer converger los comportamientos comunicacionales?

7. ¿Cómo es "vivido" el cuerpo del actor/actriz?

8. ¿Cambia el actor de cuerpo desde el momento en que abandona la vida cotidiana por la presencia escénica y la energía gastada a manos llenas?

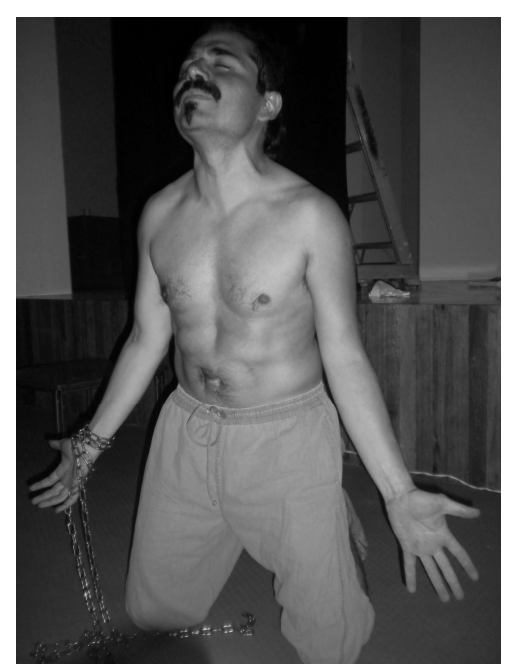

(Expresión corporal en El príncipe constante. Función en la UAM-I, 2011.)

\footnotetext{
${ }^{294}$ En La canoa de papel, Eugenio Barba explica que la actuación teatral es una conducta humana particular en una situación de representación.
} 
Este tipo de observaciones suceden hacia el interior de la naturaleza del actor, y tienen que ver con su particular funcionamiento como máquinas creativas. Tienen que ver con su ser físico, es decir, con su especial corporalidad. En tal sentido podemos afirmar, con las observaciones que desde el ejercicio de la actuación realizamos y respondiendo a Pavis:

¿De qué cuerpo dispone el actor? El cuerpo que define a una persona como actor, aun fuera de la escena, es necesariamente un cuerpo dispuesto, lo que quiere decir entrenado y listo para expresar. Es inevitable su impregnación por la cultura que lo formó pero, en todo caso, ello propicia su tipo de expresividad actoral, mediante lo que solemos llamar tradición. Luego, tanto de la tradición en que se ha cultivado este actor, como del contexto cultural del espectador que lo ve, dependerán sus posibilidades comunicativas.

¿Qué muestra, qué oculta el cuerpo? Sería muy fácil afirmar que el cuerpo del actor muestra al personaje y oculta a la persona. En realidad, lo que se puede ver es una figura, mitad ficción y mitad realidad, que combina los contextos del personaje y de la persona en una construcción que igualmente mezcla tanto el cuerpo físico del actor como el cuerpo cultural que el público, entre sus expectativas y su asombro, se permite ver.

¿Quién sostiene los hilos del cuerpo? Los hilos que sostienen al cuerpo del actor son el entramado complejo entre un concepto de puesta en escena (texto+dirección+producción colectiva), la atención del espectador (con su horizonte de expectativas, sus deseos subconscientes, su contexto cultural, y en la relación de todo esto con el actor para retroalimentar su discurso escénico) y el mismo actor. El piloto es la conciencia del actor que, inspirada, es capaz de propiciar la formación de una conciencia colectiva durante la representación.

¿Está el cuerpo centrado sobre sí mismo, conduciendo toda manifestación a un centro operacional de donde todo parte y adonde todo regresa? Lo que observamos en la orientación del cuerpo del actor con respecto de sí mismo es que, más bien, en la escena, se da un fenómeno de auto-afirmación extrema o superlativa, es decir, una súper-auto-afirmación del cuerpo, que concentra y sintetiza tanto a la persona como al personaje en una misma ecuación. 
¿Qué es lo que, en su medio ambiente cultural, se considera un cuerpo controlado o un cuerpo "desencadenado"? La condición del actor es ciertamente paradójica en el sentido de que, bajo el más riguroso control, su desempeño en la escena es en completa libertad. El control propicia la seguridad mental y corporal que necesita el actor para, en el momento de la representación, desencadenarse. Luego, es el diálogo entre este trabajo y el espectador lo que define los ritmos de acción y recepción.

¿De qué modo el cuerpo hablante y actuante del actor invita al espectador a "entrar en el baile", a adaptarse al sincronismo y a hacer converger los comportamientos comunicacionales? El actor invita al espectador a participar de la comunión teatral mediante un trabajo sugestivo, propiciatorio, por el cual captura, retiene y hace crecer su atención.

¿Cómo es "vivido" el cuerpo del actor/actriz entre el público? Desde luego, el trabajo del actor convoca una atención que en mucho depende de compartir elementos mínimos de un mismo contexto cultural, incluyendo en este background una noción física, psicológica, social y/o espiritual de cuerpo. Dependerá de este bagaje la manera en que se "viva" el cuerpo del actor en el cuerpo del espectador.

¿Cambia el actor de cuerpo desde el momento en que abandona la vida cotidiana por la presencia escénica y la energía gastada a manos llenas? El actor no cambia de cuerpo cuando pisa el escenario: lo que cambia es el uso dado a ese cuerpo. El cuerpo actoral no se niega a sí mismo en condiciones de representación. Antes bien, se reafirma, superando su propia naturaleza, para construir un significado. Más que en cualquier otro arte o profesión, en la actuación teatral se subraya la propia existencia: "Yo significo."

Refrendamos que la naturaleza corporal del actor no se limita a su condición física, sino que abarca también su capacidad emocional y mental, así como su condición cultural individual y social. El cuerpo del actor es una construcción tanto fisiológica como cultural, y su preparación y funcionamiento para la representación se salen completamente de los parámetros ordinarios. El siguiente mapa biosemiótico ilustra los aspectos obligados del entrenamiento continuo del actor y proyecta, en consecuencia, una imagen muy precisa de 
su corporalidad, entendida desde un enfoque global (cuerpo, mente, competencia comunicativa).

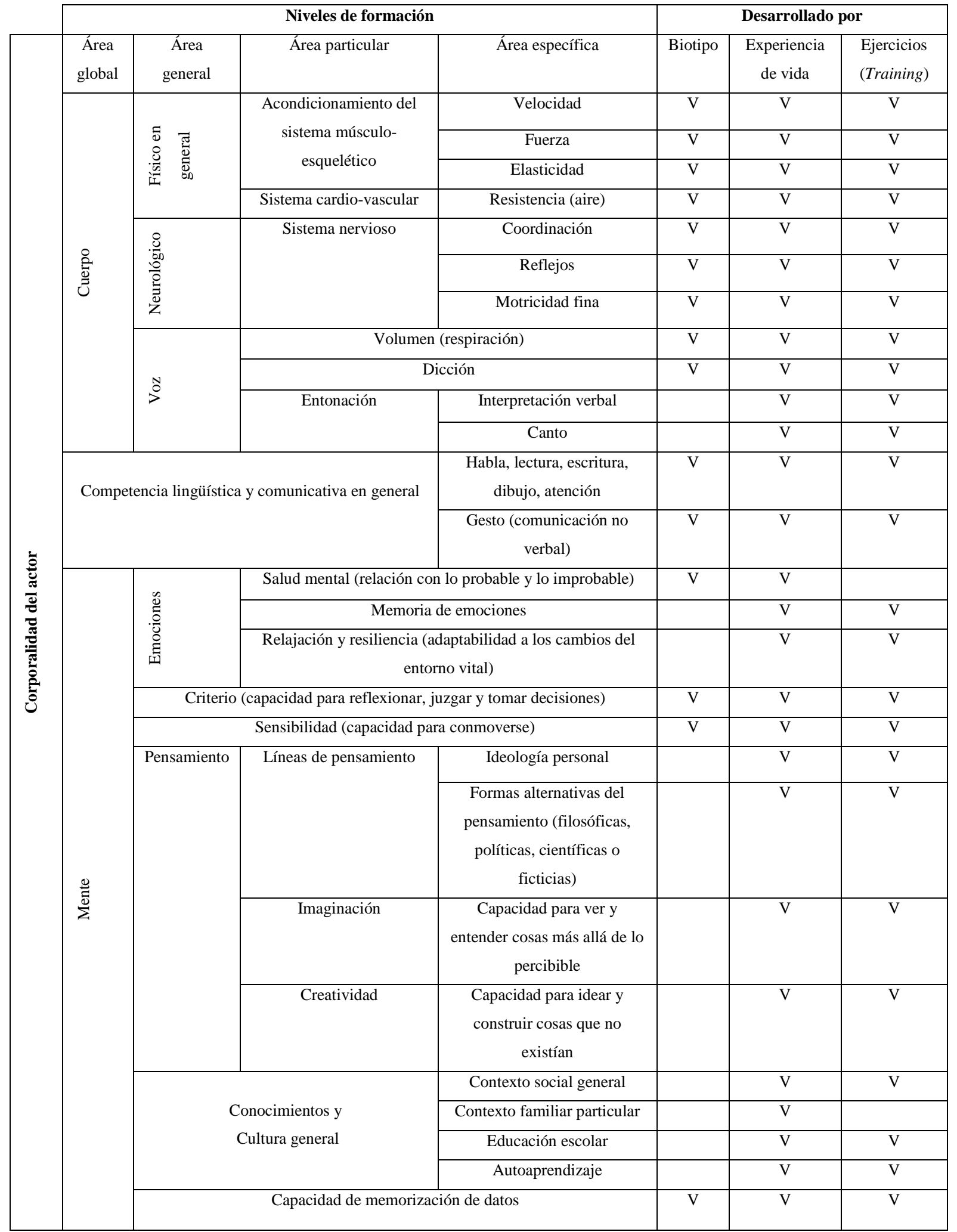

El cuerpo del actor (biosemiótica de la actoralidad) 
Este mapa escenómico permite ponderar qué tanto de la naturaleza del actor es congénita, cuánto se adquiere con la compleja experiencia de vivir y cuánto por aprendizaje especializado (entrenamiento.) De hecho, parece que no todo lo da la cuna y que, en contraste y con algunas reservas, el entrenamiento estimula y propicia el desarrollo de cuanto necesita el actor. Todo indica que el actor no sólo nace, sino que también se hace.

\section{Trascendencia literaria de las estrategias del actor como lector}

El actor es un lector profesional. Ya hemos explicado cómo la lectura del actor no es meramente contemplativa ni mucho menos pasiva. Su empatía con el personaje y sus situaciones rebasa los límites del lector recreativo (todo aquel que lee por placer) e incluso los del crítico (que pondera las virtudes y limitaciones de tal o cual obra) y los del filólogo (quien estudia, reconstruye, fija e interpreta la literatura). Cuando el actor vive al personaje está viviendo la literatura. Innegablemente, la lectura actoral es una lectura vivencial.

En esta práctica de lectura vivencial, los complejos pactos de cooperación con el espectador convierten a éste último en lector indirecto tanto del texto dramático representado como de todas las otras literaturas contextuales, intertextuales y subtextuales implicadas en el despliegue del actor. Así, desde el escenario, el actor socializa todas sus propias lecturas. De ahí que resultaría muy complicado negar que parte de la estrategia de lectura de un actor deviene en indispensable promoción y difusión de la literatura en particular, y de la cultura en general. El actor es un promotor cultural por necesidad.

No debatiremos aquí que uno de los primeros compromisos de un crítico, un filólogo o cualquier otro estudioso de la literatura debería de ser el persuadir al resto de la gente acerca de las bondades y los placeres de leer. El hecho es que no todos lo hacen. Ya explicamos cómo el actor sí.

Por otra parte, objetivamente sería difícil de sostener que la perspectiva lectora y la competencia como investigador documental de un actor comprometido sea de menor ralea que la de cualquier otro lector profesional, incluyendo en esa evaluación sus referentes teórico-conceptuales.

En consecuencia, sería pertinente tomar en cuenta con mayor seriedad la figura del actor en sus estrategias de lectura y en su función social de promotor en el marco de los estudios humanísticos y literarios profesionales, no desdeñar su perspectiva crítico- 
filológica, e incluso considerar sus prácticas de análisis y comunicación en los niveles teóricos más elevados y profundos.

\section{Creatividad y Trasgresión}

No hay duda de que la imaginación es un recurso disponible para todos los seres humanos. Los actores, sin embargo, le dan un uso particular. El actor necesita imaginar que es otro para que el espectador imagine lo mismo. La imaginación del actor debe estar tan estimulada, y ser tan estimulante, que toda su apariencia y su conducta se ajusten a la de un personaje que no existe, en un espacio que también simula ser otro, entre objetos que no son lo que aparentan y ejecutando acciones que significan mucho más, para entregarle al espectador un nuevo mundo, un mundo imaginario. Stanislavski llamaba a esta facultad del actor imaginación creadora $^{295}$, y por esta investigación ahora entendemos que se trata de una imaginación personal que logra despertar la imaginación del otro, la del espectador.

Sólo puede haber teatro a partir del momento en que se inicia realmente lo imposible. (Antonin Artaud. 1987 [1938.] El teatro y su doble. 29.)

Para que la imaginación personal del actor pueda ser tan estimulante que alcance a estimular la imaginación ajena, Ludwik Margules planteaba que el actor debe alucinar ${ }^{296}$ su personaje, es decir que, de una forma constructiva, debe estar enajenado con él. Con ello, como deseaba Antonin Artaud, el actor debe desarrollar un acontecimiento tan sugerente y provocador que se extienda por el mundo como una peste ${ }^{297}$ medieval. Es decir, que la alucinación del actor debe compartirse, ser vivida por todos. Esta ambición es posible en la escala de un foro teatral, de donde los participantes salgamos contagiados con el padecimiento gozoso de un buen espectáculo que nos haga reír, llorar y pensar.

Idear y construir cosas invisibles, improbables o que no existían es la aplicación que el actor da a su imaginación creadora. Esta capacidad también se llama creatividad. En el escenario, todo cobra sentido gracias a la creatividad del actor, porque el actor convierte un templete de madera en llanura agreste, un paraguas en espada, una silla plegable en

\footnotetext{
${ }^{295}$ En Constantin Stanislavski. 1990 (1953.) Un actor se prepara.

${ }^{296}$ En Ludwik Margules. 2004. Memorias. Conversaciones con R. Obregón.

${ }^{297}$ Ver "El teatro de la peste", en 1987 (1938.) El teatro y su doble.
} 
trono, un mantel en capa o alfombra mágica, es decir, que no sólo da vida al personaje ficticio que interpreta, sino también al espacio y a los objetos que utiliza.

La creatividad, especialmente en la actuación, significa sinceridad infinita, pero disciplinada, es decir, articulada mediante signos. (Grotowski. Hacia un teatro pobre. 220.)

No es que la tela negra deje de serlo a los ojos del espectador, ni que la cantidad de personas se multiplique mágicamente en escena. Pero lo que el actor hace creativamente es propiciar la participación activa del público mediante su propia imaginación. El actor nos invita a todos a jugar, aun sabiendo que su persona, el espacio, las acciones, los objetos siguen siendo los mismos, en un juego de resignificaciones que da nuevos nombres a su persona, al espacio, a las acciones y los objetos. Por lo tanto, el actor no sólo es propiciador de la generación de sentidos, también propicia su regeneración.

El trabajo del actor parece ser en el fondo un acto de contradecir la realidad, o lo que del mundo se dice que es real. En efecto, aunque parezca contradictorio, el oficio que tanta disciplina, autocontrol y seriedad exige, lleva implícita una vocación de rebeldía. Es rebeldía afirmar que hay otros mundos posibles, y que el teatro es un modelo de mundo donde caben todos los mundos (como la utopía neozapatista). Rebeldía es dedicar esfuerzos, tiempo y hasta dinero a una práctica que no deja mucho para comer. Rebeldía es insistir en esa práctica cuando el siguiente ejercicio parece imposible, o cuando otros afirman que lo es. Pero la profesión del actor es, precisamente, hacer posible lo imposible, visible lo invisible o, como proponía Octavio Paz, comunicar lo incomunicable.

Si el teatro es teatro, transforma el mundo, no lo imita; no solamente lo representa, lo cambia. (Luis de Tavira. 1999. El espectáculo invisible. 106.)

Con ese perfil transgresivo, el actor sabe que es el agente de un cambio social; quizá más lento y menos agresivo que un terrorista o un político, pero trasgresor al fin. El actor es un animador de las ideas de la sociedad. Aun más, es un motivador. El actor motiva burlas y lamentaciones, debates y reflexiones. Con su discreta participación en la estructura social, el actor va cultivando un cambio profundo: una pequeña revolución cultural. 


\section{Sobre la investigación teatral en los estudios de posgrado}

Después del primer proyecto The Complete Works llevado a cabo por la Royal Shakespeare Company (RSC) para representar en dos años (2006 y 2007) todos los dramas de Shakespeare, desde luego con el apoyo de reconocidas compañías nacionales e internacionales, el nuevo reto autoimpuesto por esa institución es el manifiesto Stand up for Shakespeare (consultable en el website de la compañía). Éste consiste en un ambicioso experimento para promover y difundir las obras, el arte $\mathrm{y}$, por supuesto, la ideología shakespeareana en el público desde su más temprana edad, es decir, la más tierna infancia escolar. El proyecto, coordinado por Michael Boyd (director artístico de la RSC) está respaldado por el Arts Council de Inglaterra y consiste en un referéndum abierto con tres importantes demandas:

1. "Do it on your feet." Los resultados de las investigaciones pedagógicas constructivistas han demostrado que la mejor forma de aprehender el conocimiento es "hacer", esto es, ejerciéndolo vivencialmente. En el caso de Shakespeare, es obvia la invitación a pasar de las mesas de lectura en la biblioteca a los escenarios. Ello pone en evidencia la política institucional de la RSC de entender los textos dramáticos como partituras y no sólo como literatura.

2. "See it live." Al oficializar la teatralidad de la literatura dramática, es clara también la intención de que todas las lecturas de Shakespeare se hagan en el marco preformativo, si no como actores, entonces como espectadores de una experiencia escénica.

3. “Start it earlier." La promoción y difusión de las obras de Shakespeare y del arte teatral remataría abiertamente como el proyecto de instauración de una ideología que cimiente la cultura de la población británica desde la educación básica.

El proyecto tal vez muestra lo avanzada que está la cultura teatral en el Reino Unido, y lo más lejos aún que pretende llegar, pero deja también entrever los posibles riesgos a los que se va a enfrentar pues, una vez alcanzado el apogeo de su desarrollo, la propuesta de expansión hacia el público infantil como a rajatabla puede devenir igualmente en un 
hartazgo más temprano y, por lo tanto, en una decadencia del interés por Shakespeare, con el consecuente fracaso del programa cultural.

Una variación más adecuada parece darse en China con la Ópera de Beijing (Pekín). Hace poco, las autoridades culturales de la nación asiática diagnosticaron un marcado desinterés en su juventud por su manifestación teatral más importante. Lo que entonces decidieron fue insertar una asignatura obligatoria de ópera en los programas escolares elementales, con el fin de incorporar la cultura escénica en la población desde la infancia, tal y como pretende hacerlo Inglaterra en corto tiempo. Sin embargo, los chinos empezaron a notar que la impronta, en vez de estimular y despertar el interés de sus menores hacia el arte dramático, los violentaba y les generaba más bien cierto rechazo (considerando además la dificultad de las distintas exigencias: canto, danza, acrobacia, etc.) La rápida evaluación de la estrategia didáctica permitió una óptima solución, consistente en hacer de su asignatura de ópera una materia optativa. ${ }^{298}$ Esta solución resuelve el rescate de la tradición nacional al propiciar una sensibilización temprana, pero no impositiva, hacia el arte escénico y, por otra, seguramente le dará un nuevo impulso al generar intérpretes mejor preparados, pues muchos serán aquellos que escojan esta vocación hoy, siendo todavía niños, poniendo el tiempo a su favor. Tal vez el Reino Unido podría aprender de la experiencia ajena y evitar un futuro e innecesario colapso de toda su cultura teatral.

Mientras en aquellas dos potencias económicas se investiga cómo consolidar una hegemonía cultural, en muchos otros países, como el nuestro, las riquezas culturales lucen tan mal administradas como las económicas. No se puede negar que hay mucha producción teatral, incluso mucha de decorosa calidad y, sin embargo, y a pesar de la amplia cantidad de escuelas y docentes, no podemos hablar hoy de una cultura teatral nacional. Gran parte de esta carencia la debemos, desde luego, a la falta de investigación. Como sabemos, la mayoría de la investigación académica profesional está ligada a los estudios universitarios de posgrado.

La investigación teatral en México tiene en estos días el perfil de la heterogeneidad, de la falta de rigor, del autodidactismo y del extravío porque no hay en nuestro país estudios universitarios de posgrado en artes escénicas. Los estudiosos que se desempeñan

\footnotetext{
298 En México la mayoría de las vocaciones profesionales para las artes escénicas tienen su primera manifestación como una asignatura optativa durante el bachillerato.
} 
en el Centro de Investigación Teatral Rodolfo Usigli (CITRU), en la Asociación Mexicana de Investigación Teatral (AMIT), en la Casa del Teatro, en el Centro Dramático de Michoacán, en editoriales como Escenología, El Milagro o Paso de gato, y los académicos que laboran en universidades e institutos en torno al teatro como objeto de indagación son, por lo general, profesionistas o ejecutantes de nivel pasante, diplomado, técnico o licenciado en alguna de las muchas carreras de teatro o humanidades que la nación ofrece. Muchos son maestros e incluso doctores, aunque no en teatro, sino en literatura, filosofía, antropología, historia del arte, artes visuales, estudios latinoamericanos, psicología, etc., es decir, materias que podemos llamar afines, pero no intrínsecas al teatro per se. Sin menoscabar las aportaciones que hasta el momento tantos interesados han brindado para ampliar y profundizar en el estudio del objeto teatro, hay que reconocer que los posgrados en teatro hacen falta, y que los esfuerzos por desarrollarlos no han bastado.

La formación teatral de nivel licenciatura en la región hispano-parlante fue iniciada por México, le siguieron Colombia y Cuba gracias a la fuerza de los proyectos teatrales surgidos en el siglo XX. En el caso de México es importante mencionar la coyuntura política emanada de la ideología de la revolución de 1910 y en Cuba el modelo de la política cultural implantada por la revolución de 1959. Sin embargo, lo que llama la atención es que estos países no mantuvieron su liderazgo en la dinámica del desarrollo en cuanto a los niveles de posgrado. Mientras Brasil, Argentina, Colombia y Chile inician o iniciaron ya sus programas de maestría e incluso de doctorado, en México, los proyectos de la UNAM [Universidad Nacional Autónoma de México], la EAT-INBA [Escuela de Arte Teatral del Instituto Nacional de Bellas Artes] y de la UV [Universidad Veracruzana] están en suspenso [el de maestría en la UV ya se cursa por fin]. (FEDIUK, Elka. 2003. "Investigar la formación teatral superior, Historia, realidad y deseo". 127.)

Algunas de las muchas excusas esgrimidas como si fueran argumentos hablan de la imposibilidad para dar una orientación precisa al programa emergente (¿hacia la actuación, la dirección, la dramaturgia, la crítica, la teoría, la pedagogía, la escenografía, la gestión, producción, difusión y administración cultural y comercial, la historia, la literatura dramática, el teatro corporal, los títeres y marionetas?, etc.) Otras, a la carencia de herramientas técnicas y teóricas en cuanto a metodología y background cultural para la investigación con que egresan los ejecutantes artísticos de las carreras teatrales (actores, directores, escenógrafos, a veces también algunos dramaturgos). Haría falta pues, una diversidad vasta que atienda todas las derivaciones que posibilita el territorio teatrológico, o bien, una especie de programa súper-incluyente que las contemple a todas, o a la mayoría. 
Asimismo, este o estos programas deberían incluir, como indispensable, el tema de los métodos de investigación (documental, experimental y de campo) y el bagaje teóricoconceptual que la profundización en la literatura dramática y el teatro requieren.

La tarea es compleja, pero no imposible. Considero que un programa para estudios teatrales de posgrado no puede abarcar todo el universo temático teatral, pero sí podría capacitar al estudiante para que construya él mismo su conocimiento. Igualmente, dada la naturaleza del arte teatral que tanto hemos discutido, el programa en cuestión no debe ser puramente teórico, como tampoco excluyentemente práctico, sino que debe de contemplar asignaturas de tipo mixto, es decir, de modalidad curso-taller (materias teórico-prácticas.) Debe necesariamente de orientar al estudiante, mediante seminarios (espacios para la discusión y reflexión eminentemente teórica) y tutores (atención personalizada), para desarrollar una investigación (personal o colectiva) en donde pueda ser evaluado el desarrollo de sus competencias. Finalmente, debe contar con tiempos, espacios y demás recursos para el trabajo experimental, es decir, con las condiciones de un laboratorio que le genere experiencias de aprendizaje significativas en un escenario.

No omito reconocer, sin embargo, que el Programa de Estudios de la Licenciatura en Literatura Dramática y Teatro ya ha incorporado una renovación largamente esperada, con la inclusión de asignaturas obligatorias en la modalidad de laboratorio, y que, además, también ya se cursa un nuevo Programa de Maestría en Teatro en la Universidad Veracruzana (aún hace falta el doctorado). Mientras esta u otras propuestas son consideradas por los consejos y comités correspondientes, me quedo con la imagen del actor corriendo hacia el horizonte de su culminación como artista y como investigador, es decir, con la conciencia de que la utopía, si bien es inalcanzable, hay que buscarla, como a la felicidad, como a la perfección misma.

La meta que persigo es, hasta donde me alcancen las fuerzas, hacer evidente a la actual generación que el actor es un misionero de la belleza y la verdad. Para lograr esto, el actor debe saber levantarse por encima de la plebe, en virtud de su talento, o de su autoeducación o de otras capacidades. Un actor debe ser, ante todo, una persona culta, debe ser capaz de ponerse a la altura de los genios de la literatura. (Stanislavski. [Marzo 11, 1901.] "Carta a un estudiante de teatro", en Jiménez. El evangelio de Stanislavski. 165.)

En otras palabras: El actor debe de ser un creador erudito. De otro modo, ¿qué sentido tendría el llamar "arte" al teatro y el ejercerlo como un modo de vida? Ahora propondremos 
algunas definiciones inferidas a partir de nuestras indagaciones y experimentos, así como nuevas directrices de orientación del quehacer actoral en el ámbito de su arte y en el de la investigación.

\section{Una definición de Actor}

Después de analizar experiencias y saberes teatrales, ¿qué es, pues, el actor? Nuestra siguiente reflexión es una definición propia. Esta definición expresa:

El actor es una persona que crea una representación sintética, original, creíble y fascinante de la vida, mediante su cuerpo, ideas y sentimientos, orientados intencionadamente a capturar, retener y hacer crecer la atención del espectador en cada función, para la recreación emocional, intelectual y espiritual del ser humano.

Procedemos ahora a explicar detalladamente esta definición. Punto por punto:

1. El actor es una persona: Un ser humano con identidad, cultura y cuerpo propios.

2. El actor crea: Sólo con una actitud constructiva (positiva, no destructiva, dispuesta a hacer más que a deshacer), generosa (de entrega de sí mismo en el más amplio sentido) y orientada (con reglas y límites orientados a la creación), puede el actor representar la riqueza de la vida (en todos sus aspectos: bellos y grotescos, amables y odiosos, felices y tristes, incluyendo a la muerte como parte de la vida.)

3. El actor crea una representación de la vida: El teatro, como todas las manifestaciones culturales, es un intento del ser humano por ofrecer respuestas y/o replantear preguntas acerca del mundo (o cosmos) y de sí mismo, acerca de su vida. No sólo reproduce la vida: la revisa en formas paralelas allende la reflexión cotidiana: realista, no realista, concreta, abstracta, directa o indirecta: la interpreta. El trabajo del actor es buscar, seleccionar y discriminar material vital, entenderlo racional y emocionalmente, organizarlo, sintetizarlo, darle ritmo e intensidad para representarlo de un modo extraordinario.

4. Una representación teatral de la vida ha de ser: sintética (el teatro comprime e intensifica momentos selectos y/o recreados de la vida); original (el actor 
representa la vida de una forma distinta y nueva a como se nos presenta o la entendemos ordinariamente); creíble (sin verosimilitud, es decir, sin una mínima relación con la vida -sea el discurso realista o no- en el teatro no podría darse la necesaria comunicación que lo hace un acto de común unión), y fascinante ("fascinante" es aquello que le importa a más de una persona a tal grado que les descubre respuestas, o bien preguntas, que no creían llevar en su interior y, por lo tanto, que pueden re-significar sus vidas.)

5. La creatividad del actor se apoya en su propio cuerpo: Es el contenedor de la existencia vital del actor, también su instrumento creativo. A través de su capacidad gestual, vocal y emocional, encarna al personaje, siendo así no sólo el proyector del sentido teatral sino, también, parte del signo mismo.

6. El actor también necesita de sus ideas y sentimientos: Ello implica una visión y una experiencia personal del mundo y de la vida.

7. El cuerpo, las ideas y los sentimientos del actor son orientados (dirigidos consciente $y / 0$ subconscientemente para transmitir el sentido teatral a otros) intencionadamente (con la disposición y la disponibilidad necesarias). La orientación física y psicológica de un actor (como persona dedicada a crear teatro) se alcanza con ensayos, entrenamiento, estudio y experiencia.

8. El trabajo del actor debe: capturar la atención del espectador mediante la presencia en el aquí y el ahora del actor caracterizado (esto funciona así porque, por su naturaleza vital condensada, los personajes [construcciones ficticias] lucen con más intensidad, es decir, proyectan más vida, que las personas [seres reales]); retener esa atención mediante tareas físicas y movimientos externos (trazo escénico) e internos (trabajo sobre las emociones), y hacerla crecer (sin el manejo rítmico del suspenso [construcción y resolución de expectativas] orientado para alcanzar un clímax emocional en todos los asistentes al teatro por parte del actor, el relato dramático será plano, es decir, sin emoción ni sentido).

9. El actor crea en cada función: El actor tiene el reto de trascender su experiencia cotidiana, con todo lo que le implica y que lo convierte en una persona realmente diferente cada día, para representar en cada función teatral al mismo personaje en el mismo relato dramático. Sin embargo, el reto es tan profesionalmente ineludible 
como vitalmente paradójico, pues en un sentido estricto es inevitable que el personaje proyectado en la escena vaya re-cargado en cada función con el contexto actualizado del actor.

10. El actor crea para la re-creación del ser humano. ¿Qué es la recreación? Las personas constantemente actualizamos nuestra visión del mundo y de nosotros mismos, pero no solamente acumulando conocimientos y experiencias, sino que también armando, desarmando y volviendo a armar nuestra identidad, nuestra cultura y nuestros propios cuerpos, todo lo cual podemos llamar: recreación. Ahora bien, ¿cómo se da la recreación del ser humano por medio del arte teatral? En tres niveles: emocional (lo primero que toca el trabajo del actor en el espectador son sus sentidos [ojos y oídos de manera principal] y, enseguida, sus emociones; entre la alegría y la tristeza, el amor y el odio, la entrega y la ambición, el trabajo del actor facilita recorrer al espectador la tesitura de un instrumento complejo que llamamos familiarmente "corazón”); intelectual (el trabajo del actor no solamente emociona sino que, además, invita al espectador a reflexionar acerca de sí mismo y de su mundo o, en otras palabras, de la vida), y espiritual (todos los seres humanos intuimos, acertada o equivocadamente, la presencia de algún o algunos elementos superiores a nuestra naturaleza; propiciar la relación [encuentro o reencuentro] con esos elementos es idiosincrásico del rito teatral).

\section{El arte del actor como proceso de investigación}

Nuestra definición del actor emerge desde el ejercicio práctico de la creación artística y el diálogo crítico con distintas ideas como una reflexión teórica particular, es decir, nos apoyamos en el análisis directo del fenómeno escénico actoral y en una amplia documentación correlacionada, yendo de la práctica a la teoría. De ahí que, aun en sus limitaciones como concepto, nuestra definición puede ser leída como una alternativa estética particular.

Pienso que la investigación debe proponer una manera de formular alternativas creativas en la representación y no sólo dedicarse a la documentación y análisis del fenómeno. (Gabriel Weisz, “Acústica animada”, 98.) 
Al reconfigurarse nuestro punto de vista como una alternativa creativa, se abren también nuevas posibilidades indagatorias:

1. La creatividad artística como una actividad de investigación. La aplicación de la imaginación a la construcción de una obra original pasa por el ensayo, el error y la búsqueda, entendida esta última como observación de la naturaleza, introspección crítica, contemplación de otras obras de arte, exploración teórico-práctica de formas y contenidos estéticos, y lectura y análisis de documentos muy variados (literarios en general, dramáticos en particular, teóricos, críticos, fílmicos, audiovisuales, iconográficos, etc.)

2. La obra de arte como experimento. La construcción estética es producto de un proceso amplio de indagación, de lectura (en el imaginario personal y/o colectivo, en la experiencia acumulada y aun en un bagaje documental) y de prueba (cada puesta en escena es también una apuesta estética).

3. La investigación como un acto creativo. Se investiga porque se busca una posibilidad distinta de la realidad inmediata, esto es, se imagina un mundo potencial ahí donde ahora no lo hay, de donde se reconoce que, en principio, investigar es imaginar, es decir, concebir -al menos en la ficción- otra realidad: crear un escenario alternativo. Leer es crear.

4. El espacio y tiempo estéticos como laboratorio. Se reconoce que en el ambiente controlado de la escena teatral se disponen, mezclan y combinan distintos elementos simbólicos que, por la mediación detonante del actor, se transforman para animar un mundo posible, o sea, experimental.

5. El artista como investigador. En cada nuevo proceso creativo, con cada nuevo montaje, el actor aprende, desaprende y reaprende diversos conocimientos, habilidades y actitudes: desarrolla una investigación: lee.

6. Se reconoce que todos los artistas, de una u otra manera, investigan (leen, buscan, experimentan, preguntan), aunque no todos son intencionadamente investigadores.

7. El artista-investigador. Un actor-investigador no sólo lee textos diversos, sigue instrucciones y crea una imagen y un algoritmo de acciones y pensamientos para crear un personaje, sino que además experimenta y reflexiona constantemente en 
todas las posibilidades del fenómeno escénico buscando nuevos aprendizajes significativos. El actor-investigador es un lector constante: un príncipe de la cultura.

\section{Anı̆ma o Del sentido teatral}

La estructura de una escritura dramática no está orientada a todo tipo de lector. Es una estructura dirigida a lectores-ejecutantes, es decir actores. El actor es el lector implícito en la intentio de un escritor de teatro, está en su imaginación, en su escenario virtual mientras redacta, revisa y corrige diálogos y acotaciones. Al escribir para el actor, el dramaturgo reconoce una verdad no sujeta a controversias:

Le comédien est le tout du théâtre. On peut se passer de tout dans la représentation, excepté de lui. Il est la chair du spectacle, le plaisir du spectateur. (Anne Ubersfeld. L'école du spectateur. 165.)

En este ensayo hemos aportado nociones para una manera no sólo de entender, sino también de ejercer el arte del actor, es decir, una "poética" teatral. No se trata de una reglamentación rígida para la creación artística, sino de una perspectiva particular sobre cómo puede asumirse el oficio actoral. Algunas líneas de orientación básica o acotaciones para esta "poética del actor" serían:

1.Son elementos fundamentales de la representación teatral: la premisa dramatúrgica, el concepto de puesta en escena, el espectador y el actor.

2.El actor es la encarnación viva del texto dramático. Sin el trabajo del actor, la partitura de acciones, parlamentos y silencios es sólo literatura. El actor convierte, pues, la dramaturgia en espectáculo; la contemplación en acción.

3.El actor es el ejecutante único del trazo escénico. Dice Margules: "No hay teatro sin actor. El director habla a través de las emociones, del cuerpo y del rostro del actor. El actor es el centro del espectáculo. El director expone sus ideas a través de los actores."299 El concepto de puesta en escena es una abstracción que sólo el actor puede concretar.

299 "No hay teatro sin conflicto”, en La Jornada Semanal. México, domingo 31 de mayo de 1987. 
4.El actor transforma el tiempo y el espacio real en un mundo alternativo. Es el actor quien propicia el pacto de cooperación ficcional que convierte un lugar y un momento ordinarios en una cronotopía extracotidiana.

5.El espectador se hace tal delante del actor, y no al revés. Es el público el que busca al actor en su trabajo. La contemplación sigue al acto creativo. ${ }^{300}$ ¿Y cuál sería la materia prima para lograr la comunicación teatral entre el espectador y el actor? Margules dice que: "No hay teatro sin conflicto"301, pero no sólo se refiere al que viven los personajes dramáticos: "Por supuesto que se trata de expresar los conflictos de los personajes dramáticos en el escenario, pero para esto el actor tiene que recurrir a su propia conflictiva, para de ahí tomar material de identificación con el personaje."

6.Por todo lo anterior, el actor es el alma ${ }^{303}$ del signo teatral. El término (del latín anı̆ma) define una esencia vital sin omitir un despliegue físico o material en el tiempo y el espacio. El actor es el principio sensitivo e intelectual que da forma y organiza el dinamismo del fenómeno escénico: En el actor concurren y desde el actor se proyectan todos los elementos de la representación teatral.

Es claro que no estamos diciendo que el actor sea el único fundamento para la realización del fenómeno teatral, pero sí que, sin duda alguna, es la actuación el ejercicio que da sentido a todo cuanto se percibe en el escenario (el sentido final de El príncipe constante). Obviamente, esta particular "poética" no pretende ser definitiva. La consideramos pertinente ante la necesidad de ideas que hablen del teatro y del actor; ante la necesidad de nuevos caminos para imaginar, para crear, también para leer. Más importante que lo

\footnotetext{
${ }^{300}$ No vamos a discutir aquí la cualidad creativa y artística del acto mismo de contemplación, capaz de ver un teatro en el mundo cotidiano (p.e., el "espectáculo de la vida" o "el gran teatro del mundo"), con escenarios bien definidos y actores involuntarios, es decir, personas que, en su cotidianeidad no son necesariamente conscientes de estar asumiendo roles. Nos referimos específicamente a la intencionada creación artística teatral.

301 "No hay teatro sin conflicto", op cit.

302 "No hay teatro sin conflicto", op cit.

${ }^{303}$ Podríamos pensar además en vórtice: en tanto centro de un ciclón que con gran energía absorbe la materia que lo rodea, transformándola, para luego proyectarla a enormes distancias. Pensaríamos también en detentador: como alguien que retiene provisionalmente una cosa que no es suya, mientras llega a su receptor final. Otro término, más conservador, sería depositario (que no depósito): al ser la persona a quien se confía voluntariamente una cosa valiosa, significativa.
} 
anotado hasta aquí será lo que se piense, se discuta y se cree después. Ojalá que mucho de ello se haya propiciado desde estas líneas.

\section{Consideraciones finales}

El actor es un humanista porque el teatro es humanista por excelencia: El teatro es una actividad realizada por el ser humano para el ser humano. Es una práctica cultural, pero no cualquiera. El teatro regala un nuevo sentido a la vida: una visión alternativa del ser humano y su mundo. Este sentido es gratuito en tanto que artificial y prescindible (la vida no necesita de un sentido para ser vivida, aunque quizá sí para ser disfrutada o tolerada.) El teatro, como todas las artes, es un acto de generosidad absoluta en tanto que no es redituable, es decir, que no sacia una necesidad inmediata de las personas (como alimento o salud.) El teatro no ofrece un beneficio visiblemente directo a la sociedad. Sin embargo, es un ejercicio ritual de común-unión. El teatro re-significa la existencia humana, o sea, el teatro es necesario porque le facilita al ser humano sobre-vivir. El arte del actor es construir el mundo donde caben todos los mundos. Darle voz, cuerpo y vida al otro. Leer con todos los sentidos y animar personajes y situaciones de universos paralelos que nos faciliten comprendernos mejor para ser mejores. Pero los actores no suelen pensar en esto. No importa. Aunque en su mayoría no se den cuenta, son artistas en el escenario y actores sociales en la vida cotidiana: animadores del mundo. Ser actor, por lo tanto, es una opción profesional hermosa, aunque no siempre tan redituable como para tener por ella casa, vestido, comida. Y cuando se puede, es mejor vivir para el teatro, que vivir de él. En todo caso, siempre es mejor vivir. El teatro da cuenta de ello. Hasta en la representación de una tragedia, el teatro es siempre un ritual vital, es decir, un homenaje -ya sea en calidad de exaltación festiva (celebración, confirmación) o como holocausto (puesta en crisis, cuestionamiento) - a la vida. La relación entre el arte y la vida es más que una coincidencia. El arte es un espejo, a veces fiel, a veces deformado, pero espejo al fin, de la existencia. El arte es reflexión de la vida. Hacer teatro, es decir, reflexionar la vida en homenaje o en duelo para traer belleza, alegría, riqueza espiritual, otros significados $u$ otras posibilidades de mundo, o para disfrutar la literatura clásica universal y a El príncipe constante, es prestar un buen servicio a la humanidad. 


\section{CONCLUSIONES}

Hemos confirmado que El príncipe constante es una de las grandes obras maestras de Pedro Calderón de la Barca por tratarse, en primer lugar, del emocionante relato de un soldado que lucha hasta la muerte por su dios y por su patria (un arquetipo universal). De la admiración por el valor y las virtudes de Fernando en el inicio de su campaña (antes y durante la batalla de Tánger), el lector-espectador es movido a conmoverse por su cautiverio voluntario (asumido ante su hermano Enrique) y a reflexionar con sus disertaciones acerca de la vida (en el diálogo de sonetos con Fénix) y el compromiso estoico con un propósito trascendental para bien morir (en las discusiones ante el rey de Fez). En estas Conclusiones recapitularemos todo lo hecho a partir del análisis literario de la obra y de particulares alcances logrados mediante una perspectiva crítica actoral, lo cual interesa tanto al estudio general de la literatura del Siglo de Oro (comedia española del siglo XVII) como a los ámbitos de la Teoría Literaria y del Teatro (teorías dramática y escénica) en particular.

Las características del contexto de producción ubican nuestra obra como una Comedia Nueva, tal y como dio en llamarse a toda la producción dramatúrgica a partir del Arte nuevo de Lope de Vega. "Comedia” la llama el mismo Calderón. Sin embargo, por su estructura dramática y las trayectorias de sus personajes podría ubicarse como tragedia (por la caída y muerte de Fernando), comedia (por las intervenciones de Brito y por el final feliz dada la victoria postrera de los portugueses sobre los moros), tragicomedia (así han definido los críticos a la tragedia con final feliz y al drama en donde después de muchos obstáculos se obtiene una riqueza espiritual), melodrama (por la anécdota secundaria de Muley y Fénix) y obra didáctica (por las intenciones moralizantes del perfil hagiográfico de la obra, análogas a la comedia de santos y, en algunos pocos aspectos, al auto sacramental). Estas decodificaciones tan diversas de El príncipe constante la enriquecen al pluralizar sus posibilidades de lectura y de interpretación. Es en este sentido que es pertinente su lectura trágica y un profundo y cuidadoso análisis.

Leer la obra como tragedia significa escoger una de sus muchas posibilidades interpretativas, poniendo énfasis en la trayectoria descendente del protagonista (de elevada y buena a baja y mala), de ser un maestre, un infante, un príncipe, a ser un cautivo, un 
esclavo y un mártir, con sus causas (una invasión con pretexto religioso), desarrollo (primero éxito, luego cautiverio) y consecuencias (la muerte). En otras palabras, significa concentrarnos en el personaje principal, sujeto de la acción esencial de la historia. Esto condiciona asimismo la versión espectacular, pues una representación no podría perseguir el mero divertimento del público. Después de hecho este análisis era de interés procurar la exploración de sus posibilidades representacionales, un nivel todavía muy poco estudiado en trabajos de investigación académicos.

El tomar en cuenta la representación de la obra El príncipe constante es importante por tratarse de un texto dramático, es decir, un género literario concebido con la intención esencial de verse escenificado (intentio autoral fundamental en estas literaturas). La escenificación compromete asimismo una lectura profunda al requerir considerar a detalle el espacio, el tiempo, la relación entre los personajes, así como de éstos su pensar, su sentir, sus acciones, omisiones, palabras y silencios. La lectura en ese mismo sentido puede ser todavía más profunda si se realiza desde la perspectiva del actor (el intérprete del protagonista Fernando, primordialmente), puesto que la lectura actoral exige un nivel de empatía consciente entre la persona-lector-actor y el personaje, en una relación donde el actor presta su cuerpo al ente ficticio y el ente ficticio una serie de tareas verbales (diálogos y silencios) y físicas (acciones externas [gestos] e internas [atmósfera psicológica]). El resultado de esta relación actor-personaje, aunque está apoyado sobre un texto prescrito, es una creación original no previsible por completo para el dramaturgo, el lector, el actor mismo, o para el espectador, y es el discurso espectacular. En este trabajo nos referimos al discurso espectacular como la relación actor-espectador que se da durante la representación teatral. El discurso espectacular es imprevisible porque se desarrolla sólo en un presente efímero, sujeto a la volatilidad del universo real: la vida misma (las condiciones objetivas de representación abarcan en los hechos desde cuestiones económicas básicas hasta la compleja vida personal del intérprete). De cualquier manera, de una lectura donde se comprometen el cuerpo y la conciencia integral del lector deducimos: Una lectura actoral es una lectura vivencial.

El contexto cultural del Barroco ya ofrecía un vasto menú de resoluciones espectaculares para la literatura dramática, desde el teatro trashumante, pasando por el Corral de Comedias y las fiestas de Corpus, hasta el teatro cortesano. En principio, una obra 
como El príncipe constante de Calderón podría haber sido montada en casi cualquier variedad espectacular. En el teatro trashumante, por ejemplo, pudo haberse representado explicitando las didascalias y la falta de actores con un "agora sale la dama y dice esto"; o en el Corral, donde el pueblo buscaba esparcimiento y con esa justificación acaso se incluyeron los seductores enredos amorosos de Fénix y Muley (posiblemente como colaboración de Rojas Zorrilla) y las gracias de Juan de Silva, "Brito" (recurso no desaprovechado por Calderón para hacer burla de sus enemigos); o en Corpus, como ocasión para socializar la vida ejemplar y moralizante de un santo plenamente acreditado (O Infante Santo Fernando le llaman en Portugal); o en la Corte, con su lenguaje docto pleno de referencias al estoicismo senequista y al pesimismo general del Barroco, así como a los novedosos recursos de la tramoya italiana (en proceso de inserción a España precisamente a partir del año de creación de El príncipe constante, 1629). Es factible que originalmente la obra fuera pensada para la última opción más que para cualquier otra, dada la preeminencia de la anécdota trágica (menos popular que la comedia), lo rebuscado y exquisito del lenguaje (con referencias léxicas y filosóficas más cercanas a la educación noble) y los requerimientos para su producción material (las didascalias implícitas sugieren el uso de un espacio amplísimo, así como efectos de tramoya como barcos, tormentas, batallas con caballos y apariciones fantasmales, muy caros para las compañías de Corral o imposibles para el teatro trashumante), todo lo cual hace pensar en un receptor implícito palatino.

La carencia de recursos suficientemente holgados para producir la escenificación de El príncipe constante con actores contratados para todos los personajes, el diseño y realización de vestuarios, utilería, escenografía y efectos especiales tal y como son sugeridos en el texto original no es una razón para dejar de representarla. Ya en su propio tiempo, se sabe que Calderón tuvo que realizar adaptaciones de sus propias obras para adecuarlas a las condiciones objetivas de representación, sin traicionar por ello su espíritu original. Posteriormente, uno de los más destacados lectores de El príncipe constante fue Goethe, quien no parece haber dudado mucho en preparar una adaptación propia de la obra para poder representarla.

Buscando entre las teorías escénicas contemporáneas aquella que respondiera al espíritu calderoniano vivo en El príncipe constante encontramos el Minimalismo teatral, el 
cual en su exploración de los valores más esenciales, profundos, en otras palabras espirituales del arte, se asemeja a las más graves exploraciones místicas del Barroco. En ese contexto, el director Jerzy Grotowski, acompañado de un actor como Rizsard Cieslak, ya fueron capaces, en los años 60 y 70 del siglo XX, de crear un espectáculo Neobarroco a partir de la obra maestra de Calderón.

Por otra parte, parece ser que en el Barroco original ya existía una forma previa de Minimalismo teatral entre las compañías de teatro trashumante también llamadas "de la legua”. Los cómicos de la legua dobleteaban personajes, es decir, un actor hacía de dos o más personajes; sus vestuarios, decorados y utilería eran toscos, muchas veces improvisados y primitivos; la maquinaria de tramoya no existía para ellos, su recurso principal era la sugestión detonada en el espectador por la palabra y el gesto actoral. La más humilde entre estas humildes teatralidades fue el bululú, integrada por un representante único.

En contraste, en metrópolis como Madrid el oficio actoral alcanzaba el reconocimiento profesional y, por lo tanto, la protección del estado y la legalización de sus ingresos, todo lo cual facilitaba el pago de salarios (¡vivir de la profesión!), la adquisición de vestuario y utilería, la construcción de escenarios y escenografías, el diseño y elaboración de decorados y tramoyas y, en general, el desarrollo de una compleja cultura teatral. En ese contexto sobresale en particular el nombre de un actor: Antonio García de Prado, más conocido como Antonio de Prado, famoso como exitoso empresario teatral (autor de comedias), respetado hombre de familia y buen intérprete. La confirmación formal de su estatus está documentada con su afiliación a la Cofradía de Nuestra Señora de la Novena, lo cual no sólo lo acreditó para representar en las fiestas de Corpus, sino que le aseguró la licencia general del rey y de la iglesia para ejercer y vivir como actor.

Hemos concebido para nuestro estudio actoral de El príncipe constante una reintegración del texto dramático a sus condiciones contextuales de representación (históricas, culturales, sociales, estéticas) en un escenario virtual: La imaginaria penitencia del actor Antonio de Prado para representar en bululú (como representante solitario) el primer borrador manuscrito de Calderón de El príncipe constante (con apenas el argumento nodal de la tragedia del infante Fernando), en una ermita lejos de Madrid, a una legua de Barcelona (un espacio alternativo despojado de la complejidad de la arquitectura teatral), 
para ameritar su ingreso a la Cofradia de la Novena y ser, por lo tanto, reconocido como actor. Para lograr esta reintegración, hemos articulado que:

1. Históricamente, son coetáneos Calderón, Antonio de Prado y el bululú, por lo cual es creíble, verosímil, establecer una relación imaginaria específica para la puesta en escena de El príncipe constante.

2. Desde el punto de vista cultural, el bululú es una modalidad espectacular del Barroco que se corresponde muy convenientemente con el Minimalismo teatral contemporáneo, lo que facilita realizar una puesta en escena leal.

3. En el proceso del reconocimiento social de su profesión, no es inverosímil imaginar a Don Antonio de Prado enfrentando el requisito de una penitencia como examen de ingreso a la Cofradía de la Novena. En este sentido, es razonable suponer que el requisito consistiera en purificar sus capacidades actorales en la humildad de una ermita (despojado de los recursos del corral y de la Corte), como un solitario bululú (lejos de su famosa compañía).

4. Estéticamente, esta concepción escénica es una respuesta creativa a las condiciones presentes y reales de representación que enfrentamos. Buscada y hallada como un estilo Minimalista posmoderno, responde además plenamente al espíritu original de la obra (se respeta el argumento nodal de la lucha heroica, el cautiverio estoico y el martirio sacro de Fernando), y a su contexto original de producción (el bululú, sus recursos actorales, usos y costumbres del oficio), lo que lo acredita como Neobarroco.

Con estos fundamentos sumados al cuidadoso análisis literario previo, se intervino el texto conocido de El príncipe constante para recrear el hipotexto desconocido, esto es, el primer borrador de Calderón (anterior en nuestra ficción al conocido manuscrito 15.159 de la Biblioteca Nacional de España), y se agregaron las notas que hubiera hecho Don Antonio para volverlo una partitura actoral: el texto espectacular (el texto dramático editado y enriquecido con las notas y observaciones del director, el escenógrafo y el actor mismo fara facilitar su representación). 
En etapas avanzadas de esta intervención, todavía antes de la primera función formal, se comenzó a estudiar la reacción del espectador mediante el recurso de lecturas dramatizadas y ensayos abiertos. Esta recepción preliminar permitió depurar el ejercicio representacional para reducir las distancias entre la obra original de Calderón de la Barca y el receptor final: el espectador. En este proceso se utilizaron algunos postulados de la teoría de la recepción como premisas estéticas: si los estudiosos han observado que de todos modos el creador final del sentido de una obra es el receptor final (entendido como participante activo y no nada más contemplativo en el circuito comunicativo del arte), entonces es oportuno adelantarse a interceptarle, cuestionar y aprovechar sus comentarios, dudas y críticas, integrándolos explícitamente como los cocreadores que de hecho son. En esta retroalimentación nunca dejó de ser el agente crítico-integrador el actor.

El resultado final de nuestra lectura actoral experimental confirma las observaciones del Pinciano, Rodríguez Cuadros, Ubersfeld, De Toro y muchos otros sobre la naturaleza del texto dramático como partitura, es decir, como una literatura concebida para ser ejecutada (más que meramente contemplada en el papel) en el marco de la construcción de un discurso estético más complejo: el espectacular. Se valida la escena como el mejor laboratorio para investigar la obra teatral (la puesta en escena como proceso de investigación), donde de hecho cada función actualiza su significado pues cada representación es irrepetible: cada función de El príncipe constante es una nueva lectura.

En este sentido, para el caso de El príncipe constante se hizo claro que respetar la naturaleza de la literatura dramática como partitura es la opción que más posibilidades para su lectura e interpretación ofrece, siendo la lectura con perspectiva actoral la más profunda de todas por la empatía exigida con las circunstancias, situaciones, ideas, sentimientos, acciones, omisiones, diálogos y silencios del personaje dramático, todo ello encarnado en el aquí y el ahora de la representación teatral por el actor. Esto significa que la lectura específica que lleva a cabo este ejecutante es una clara experiencia integral (lectura+interpretación+creación), pues su ejercicio compromete toda su atención, sus sentidos, su conciencia, sus propias emociones e ideas (compartidas o aun en discusión con las del texto representado) y el gesto de su cuerpo entero en voz y movimiento (explícitos o contenidos). Todo esto lo vimos en el profundo análisis del texto calderoniano y en el 
estudio interpretativo de su personaje protagonista, el príncipe Fernando. La lectura actoral es una lectura vivencial.

Al leer e interpretar El príncipe constante de Calderón desde una perspectiva actoral, se concluye que la estrategia de lectura de un actor de teatro cubre hasta tres niveles:

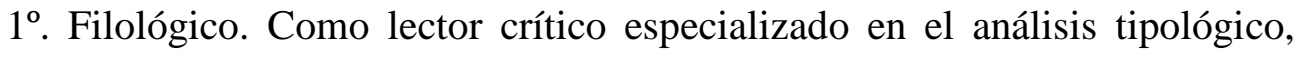
estructural, teórico y genérico del texto dramático.

$2^{\circ}$. Vivencial. Dada la empatía psicológica y emocional con los personajes, caracteres, situaciones y trayectorias, tanto a nivel personal-individual (en el estudio íntimo del actor) como colectivo-colaborativo (con el resto de sus compañeros en la empresa teatral), derivado de lo cual la experiencia lectora es, por necesidad, más profunda y significativa.

$3^{\circ}$. Social. La lectura del actor lleva, por necesidad, a la promoción y difusión de la literatura al compartirla durante la representación.

Allende, se pone en evidencia que el ejecutor del tránsito texto-escena, el actor, no es un mero intermediario entre el dramaturgo y el espectador, sino que su participación es creativa, o sea cocreadora del discurso escénico en general pues, en particular, es el verdadero creador artístico de la vida del personaje teatral (por su lectura-interpretación personal del personaje literario).

Como derivación del análisis cuidadoso de El príncipe constante, se dibujan nuevas posibilidades interdisciplinarias para el estudio de la literatura y las humanidades mediante enfoques particulares de la semiología, la historia, las artes visuales, la teoría de la recepción, la antropología y el método rizomático. Para nuestro caso, en semiología, atendiendo la complejidad de los signos dramáticos (el dramema como un nuevo enfoque del análisis actancial) y teatrales (las funciones significantes del actor); en historia, transitando de la macrohistoria de España y Portugal, pasando por sus escenarios y reyes, a la microhistoria del actor Antonio de Prado; en las artes visuales, haciendo análisis comparativos entre el Barroco, el Minimalismo posmoderno, la literatura y el teatro; en estética de la recepción, en las posibilidades reales y leales para la recepción 
contemporánea de una obra del siglo XVII; y en cuanto al método Rizoma, por las licencias críticas que sugiere (saltos transdisciplinarios, analogías, desterritorializaciones, líneas de fuga, mapas), mismas que nos permitieron imaginar y aterrizar un estudio original y exhaustivo de El príncipe constante de Calderón.

A partir del método rizomático o Rizoma se justifican, sin por ello perder rigor metodológico ni coherencia en el trabajo, recursos alternativos de investigación, formas poco usuales o definitivamente inéditas: El comparatismo entre las artes visuales y la literatura no es tan ajeno ${ }^{304}$, pero sí lo es la extensión de esas relaciones al fenómeno teatral y a la actoralidad con el involucramiento de conceptos de historia, sociología, semiología (inter, multi y transdisciplinariedad); el ejercicio de un apócrifo como medio para facilitar la comprensión de una lectura particular (analogía con las prácticas dramatúrgicas y actorales del Barroco); la ampliación de la noción de texto para entender al drama como partitura y sus derivaciones en texto espectacular y discurso escénico en el marco de un estudio literario (línea de fuga para dibujar una perspectiva actoral); entender la literatura como un fenómeno que rebasa la puesta en papel (desterritorialización del concepto literatura de la rigidez del libro); la literatura dramática no como obra acabada, sino como mapa de un modelo en constante deconstrucción (armado+desarmado+rearmado, siempre a partir de nuevos esquemas y propósitos). Una línea de fuga más audaz: El proponer un análisis rizomático específico desde la perspectiva del actor como un modelo no meramente ocasional (contingente) de lectura analítica integral, sino a reproducir y por desarrollar más ampliamente, incluso más allá de la literatura, como un marco teórico para generar agenciamientos y rutas en la crítica humanística y el activismo cultural (agentes y protocolos de investigación, interpretación y acción en escenarios del gran teatro del mundo real), y las bases incipientes para una poética del actor como lector, nos permite sugerirle un nombre provisional: escenoma.

Se actualiza el estado de las discusiones acerca de las relaciones entre la literatura dramática y el teatro, lo que supone una aportación de interés al campo de la teoría literaria en general, y a los de las teorías dramáticas y escénicas en particular. Particularmente se pone al día el estudio de la participación del actor en la evolución del texto dramático hacia su versión espectacular. Se ponen en evidencia las estrategias creativas del actor como

\footnotetext{
${ }^{304}$ Tan sólo recordemos el clásico de Arnold Hauser Historia social de la literatura y el arte.
} 
lector. Se denota la naturaleza creativa y vivencial del ejercicio lector desde la perspectiva actoral. Se reconoce la figura del actor como un modelo de lector particular activo y creativo, y a la actoralidad como un espacio para la investigación literaria y humanística. Se denota la utilidad de aprovechar la figura de un actor-investigador no sólo para el ámbito teatral-escénico, sino para dilatar positivamente los de la literatura y las humanidades. Se ofrecen nuevas herramientas (como lector crítico, como espectador activo y como ejecutante actor) para el estudio de la literatura dramática, particularmente del teatro del Siglo de Oro Español, el Drama Barroco. En resumen: se demuestra que en una lectura actoral no solamente se puede conocer de poetas y de letras sino, además, vivir en los labios y en la piel sus versos.

Finalmente, se celebra la oportunidad de renovar el goce imperecedero del teatro español del Siglo de Oro (en su doble dimensión literaria: puesta en papel, y espectacular: puesta en escena) a través de un paradigma tan destacado como El príncipe constante de Pedro Calderón de la Barca. 


\section{FUENTES}

ABEL, Lionel. 1963. Metatheatre, A new view of dramatic form, NY: Hill and Wang. ADORNO, Theodor, et al. 1969. El teatro y su crisis actual, Caracas: Monte Ávila.

ALATORRE, Claudia Cecilia. 1994 (1986.) Análisis del drama. México: Gaceta.

ALCÁNTARA MEJÍA, José Ramón. 2003. "De Aristóteles a la Post-Postmodernidad: Una trayectoria en investigación teórica teatral", en Investigación teatral, Revista de la AMIT. Número 3, enero-junio de 2003. 25-36.

ALVARES, João, O.A. 1730. [1406?-ca 1490.] Chronica dos feitos, vida e morte do Iffante [sic] sancto Dom Fernando que morreo em Feez. - Reuista \& reformada agora de nouo pelo padre frey Hieronymo de Ramos da Ordem dos Preegadores. $3^{\mathrm{a}}$ reimp. - Lisboa Occidental: Miguel Rodrigues.

ARAUJO, Nara y Teresa DELGADO. 2010. Textos de teorías y crítica literarias (Del formalismo a los estudios postcoloniales). México: Anthropos / UAM-I.

ARISTÓTELES, Poética. Madrid: Gredos, 1974. (Edición trilingüe de Valentín García Yebra).

ARTAUD, Antonin. 1987 (1938.) El teatro y su doble. México: Hermes / Sudamericana.

2006 (1936.) Mensajes revolucionarios (Selección de textos periodísticos aparecidos en México en 1936.) México: Letras Vivas.

BARBA, Eugenio. 1992. La canoa de papel. México: Escenología / Gaceta. 1986. Más allá de las islas flotantes, México: Gaceta/UAM.

BARBA, Eugenio y Nicolás SAVARESE (Editores.) 2009 (1990.) ANATOMÍA del actor, Diccionario de antropología teatral, México: Escenología.

BENJAMIN, Walter. 1955. "Das Kunstwerk im Zeitalter seiner technischen Reproduzierbarkeit" (La obra de arte en la era de la reproducción mecánica, o The work of art in the age of mechanical reproduction), en Schriften. Frankfurt: Suhrkamp Verlag. (Band I: 366-405.)

2003 (1935-1936). La obra de arte en la época de su reproductibilidad técnica [Urtext]. México: Itaca / David Moreno Soto / CONACULTA. Traducción de Andrés E. Weikert. Introducción de Bolívar Echeverría.

BENTLEY, Eric. 1985. La vida del drama, México: Paidós.

BERISTÁIN, Helena. (1982.) Análisis estructural del relato literario. México: UNAM/Limusa.

BETANCOURT, Javier. 2001. "Secretos de familia: Mifune, Dogma 3", en Revista Proceso, México: 14 de Enero. pp. 64 y 65.

Biblioteca básica multimedia. 1998. Madrid: F \& G Editores. Edición en CD.

BLOOM, Harold. 1995. El canon occidental. Barcelona: Anagrama.

BOAL, Augusto. Teatro del oprimido.

BOBES NAVES, María del Carmen. 2001. Semiótica de la escena. Madrid: Arco. 1991 (1987.) Semiología de la obra dramática. Madrid: Taurus.

BOYD, Michael (coord.) 2009. Stand up for Shakespeare. A manifesto for Shakespeare in schools. Stratford upon Avon: RSC / Arts Council.

BRECHT, Bertolt. 2004 [1933-47.] Escritos sobre teatro. Barcelona: Alba.

BROOK, Peter. 1994 (1993.) La puerta abierta. Reflexiones sobre la interpretación y el teatro. Barcelona: Alba.

1973 (1968). El espacio vacío, arte y técnica del teatro. Barcelona: Península.

CALVINO, Italo. 1989. Bajo el sol jaguar. Barcelona: Tusquets.

CARDUCHO, Vicente. 1979 [siglo XVII]. Diálogos de la pintura. Su defensa, origen, esencia, definición, modos y diferencias. Madrid: Turner.

CARVER, Raymond. 1997 (1976). ¿Quieres hacer el favor de callarte, por favor? Barcelona: Anagrama.

CASTAGNINO, Raúl H. 1967. Teoría del teatro. BA: Plus Ultra.

CASTRI, Massimo. 1978. Por un teatro político: Piscator, Brecht, Artaud. Madrid: Akal. 
CERVANTES SAAVEDRA, Miguel de. 2005 (1605.) Don Quijote de la Mancha. México: Real Academia Española, Asociación de Academias de la Lengua Española, Alfaguara.

CHEVALLIER, Jean-Frédéric. 2005. "Del imaginario al movimiento", en Paso de gato. Año 4, número 21. Abril-junio de 2005. 16.

CHOCRÓN, Isaac. 1968. Tendencias del teatro contemporáneo, Venezuela: Monte Ávila.

CLURMAN, Harold. "La lectura de la obra", en Máscara. Núms. 7-8. Págs. 4-29.

COLE, Toby (compilator.) 1995 (1947.) Acting, A handbook of the Stanislavski Method. (Introduction by Lee Strasberg.) Revised edition. NY: Crown Publishers.

COVARRUVIAS OROZCO, Sebastián de. 1611. Tesoro de la lengua castellana. Madrid: Luis Sánchez (Impresor del Rey.) Edición facsimilar en línea de la Universidad de Sevilla.

CRAIG, Edward Gordon. 1995 (1911.) El arte del teatro. México: Gaceta.

CUESTA ABAD, José Manuel y Julián JIMÉNEZ HEFFERNAN (edits.) 2005. Madrid: Akal.

DEI LIBERI, Fiore. 1410. Flos duellatorum. Manual de esgrima y combate, edición facsimilar en línea.

DE ITA, Fernando. 1999. Telón de fondo. México: CONACULTA.

DELEUZE, Gilles. 1987. Foucault. México: Paidós.

DELEUZE, Gilles y Félix Guattari. 1988 (1979). Mil mesetas: capitalismo y esquizofrenia. Valencia: Pre-textos.

1978. Kafka, Por una literatura menor. México: Era.

1975. Kafka, Pour une littérature mineure. Paris: Les Editions de Minuit.

DE MAN, PAUL. 1990 (1986). La resistencia a la teoría. Madrid: Visor.

DE TAVIRA, Luis. 2010. Interpretar es crear. Reflexiones críticas sobre la diversidad conceptual del hacer del actor. México: Paso de gato.

y Stefanie WEISS. 2009. Ser es ser visto. México: Compañía Nacional de Teatro / Jus.

2001. "Brecht: Un poeta por encima de todo", entrevistado por Rubén Ortiz para el Programa de Mano de Santa Juana de los Mataderos. (Cuadernos del espectador.) México: CONACULTA. 9-17.

. 1999. El espectáculo invisible. Paradojas sobre el arte de la actuación. Madrid: Asociación de Directores de Escena de España.

DE TORO, Fernando. 1989 (1987.) Semiótica del teatro, del texto a la puesta en escena. BA: Galerna.

Diccionario de autoridades. 1726 y 1739. Madrid: Real Academia Española.

Diccionario de la lengua española. (DRAE.) 2006. Madrid: Real Academia Española.

Dicionário Histórico, Corográfico, Heráldico, Biográfico, Bibliográfico, Numismático e Artístico. 1904-1915. Lisboa: João Romano Torres - Editor. Edição electrónica: Manuel Amaral, 2000-2010.

DIDEROT, Denis. 1994 (1773). La paradoja del comediante. México: Ediciones Coyoacán.

DÍEZ BORQUE, José María y L. GARCÍA LORENZO, (comps.) 1975. Semiología del teatro, Barcelona: Planeta.

DIEZ BORQUE, José María (editor.) 1989. Actor y técnica de representación del teatro clásico español. Londres: Támesis.

ECO, Umberto. 1986. La estructura ausente, Introducción a la semiótica, Barcelona: Lumen. 1988 (1980.) El nombre de la rosa. México: Lumen, Representaciones editoriales.

1970. La definición del arte. BCN: Roca.

1970. "El problema de la obra abierta", en La definición del arte.

ELAM, Keir. 1994 (1980). The semiotics of theater and drama, London and NY: Routledge.

ELLIOT, Julián. 2005. "La vida por el honor", en Historia y vida. Agosto de 2005. No. 449, año XXXVII.

Encarta Enciclopedia. 2000. Microsoft. CD.

ENGLER, Barbara. 1996. Introducción a las teorías de la personalidad. México: McGraw-Hill. 
ESCALANTE, Ximena. 2001. "El efecto 'V'”, en el Programa de Mano de Santa Juana de los Mataderos (Cuadernos del espectador.) México: CONACULTA. 20-22.

_. 2001. "El paisaje de San Cayetano", en el Programa de Mano de Santa Juana de los Mataderos (Cuadernos del espectador.) México: CONACULTA. 27-30.

ESSLIN, Martin. 1995 (1976.) An anatomy of drama, NY: Hill and Wang. 1961. The theater of the absurd. NY.

ESSLIN, Martín. "La estructura del drama", en revista Tramoya. México: Universidad Veracruzana.

FEDIUK, Elka. 2003. "Investigar la formación teatral superior, Historia, realidad y deseo", en Investigación teatral. Revista de la Asociación Mexicana de Investigación Teatral (AMIT.) Número 3. Enero-Junio de 2003. 109-143.

"Fernando de Portugal, beato", en Páginas electrónicas de la Arquidiócesis de Madrid. 2010. Iglesia Católica de España.

FORTUÑO GÓMEZ, Vanessa. 2007. "La vida teatral en Barcelona en el siglo XVII: las compañías de Juan Martínez, Juan Acacio y Manuel Ángel (1628-1688.)" CRITICÓN. Núm. 99. 159166. Artículo en línea en el Centro Virtual Cervantes.

FOUCAULT, Michel. 1966. Las palabras y las cosas.

FREIRE, Paulo. 2005 (1970). Pedagogía del oprimido. México: Siglo XXI.

FREUD, Sigmund. 1897. Los orígenes del psicoanálisis (Cartas 64, 71 y 74 a Wilhelm Fliess, cits. en Keitlen 17-19.)

GARCÍA-PELAYO, Ramón. 1975. Pequeño Larousse en color. Barcelona: Noguer.

GIELGUD, John. 2001 (1991), Interpretar a Shakespeare. Barcelona: Alba.

GONZÁLEZ, Luis Armando. "Neoconservadores, posmodernos y teóricos críticos", en Revista Política. (Ver www.cepcom.mx/metapolitica/1/gonzalez.html.)

GOUTHIER, Henri. 1961. La obra teatral, BA: Eudeba.

GOUTMAN, Ana. 1995. Estudios para una semiótica del espectáculo, México: UNAM.

GREIMAS, Algirdas Julián. 1987. (1971.) Semántica estructural, Investigación metodológica, Madrid: Gredos.

GROTOWSKI, Jerzy. 1990. "Respuesta a Stanislavski”, en Jiménez 1990. 487-504.

1989 (1968.) Hacia un teatro pobre. (Towards a por theatre.) México: Siglo XXI.

. 2003. Apocalypsis cum figuris (Descripción del espectáculo por Malgorzata Dzieduszycka). Maldoror.

GUICHARNAUD, Jaques. 1963. Modern French theatre from Giradoux to Beckett, New Haven: Yale University.

GUIRAUD, Pierre. 1978. La semiología, México: Siglo XXI.

HARTNOLL, Phyllis. 2003 (1968.) The Theatre. A Concise History. London: Thames \& Hudson (Updated by Enoch Brater.)

HAUSER, Arnold. 1998 (1962). Historia social de la literatura y el arte I (Desde la prehistoria hasta el barroco), Madrid: Debate.

1975. Teorías del arte, tendencias y métodos de la crítica moderna, Madrid: Labor.

Hazañas del Cid Campeador. 2008. México: Porrúa.

HELBO, André (comp.) 1978. Semiología de la representación: teatro, tv, cómic. BCN y México: Gili.

HERNÁNDEZ GONZÁLEZ, Erasmo. 2011 (consultado en.) "Estudio de La despreciada querida de Juan Bautista Villegas". Artículo en línea.

HISTORIA DEL ARTE. 1997. BCN: Océano. Enciclopedia en 16 volúmenes.

INNES, Christopher. 1995. El teatro sagrado, El ritual y la vanguardia, México: FCE.

ISSACHAROFF, Michael. 1981. "Drama and the Reader" [reseña sobre Lire le thèatre], Poetics today, 2: 1981, núm. 3, 255-263.

IVERS, Ian Clu, et al. 1992. Diccionario de arte, Madrid: Alianza. 
JAMESON, Frederick. 1991. El posmodernismo o la lógica cultural del capitalismo avanzado. BCN y México.

JIMÉNEZ, Sergio. 1990. El evangelio de Stanislavski según sus apóstoles, los apócrifos, la reforma, los falsos profetas y Judas Iscariote. (Escenología 12.) México: Gaceta.

y Edgar CEVALLOS. 1988. Técnicas y teorías de la dirección escénica, México: Gaceta.

JOVER ZAMORA, José María; Marc Baldó i Lacomba y Pedro Ruiz Torres. 1997. Historia y civilización: Escritos seleccionados. Valencia: Universitat de València.

KEITLEN, Seymour. 2005. El complejo de Edipo. México: EDIMUSA.

KOWSAN, Tadeusz, "El signo en el teatro, Introducción a la semiología del arte del espectáculo" (en Adorno et al).

LAO TSE. 1990 (¿siglo I a.C.?) Tao te king, libro del tao y de su virtud. Santiago: Cuatro vientos.

LAWSON, John Howard. (1960.) Teoría y técnica de la dramaturgia, México: Cuadernos del CUEC/UNAM.

. 1960. Theory and technique of playwriting, with a new introduction, NY: Hill and Wang.

LEE ZOREDA, Margaret. 1991. "Bajtín y la alteridad en ciencia ficción”, en Acciones Textuales, Revista de teoría y análisis de la UAM-Iztapalapa. Año 2, enero-junio de 1991. 83-92.

LEFEBVRE, Henri. 1983. La presencia y la ausencia, Contribución a la teoría de las representaciones, México: FCE.

LEÑERO, Carmen. 2007. “Conferencia Magistral.” Participación en el 1er Coloquio de las Artes Escénicas, organizado por Jorge Prado Zavala para el III Encuentro de Teatro del IEMS. Miércoles 9 de mayo de 2007. Reseñada en el Boletín Informativo del IEMS. Vol. III, no. 44, 15 de mayo de 2007.6 y 7.

. 2003. "Palabra poética y teatralidad", en Acta Poética. (Revista del Instituto de Investigaciones Filológicas de la UNAM.) Número 24-1, primavera de 2003. 225-257. . 2000. La luna en el pozo. México: CNCA.

LOPE DE VEGA Y CARPIO, Félix. 1609. Arte nuevo de hacer comedias. Biblioteca Virtual Miguel de Cervantes.

. El guante de doña Blanca.

. Fuente Ovejuna. Biblioteca Virtual Miguel de Cervantes.

. Lo fingido verdadero.

LÓPEZ PINCIANO, Alonso. 1596. Philosophia Antigua Poética. Madrid: Google. (Edición digital facsimilar.)

LÓPEZ-PORTILLO ROMANO, Paulina. 1999. El horror. México: Ediciones Coyoacán.

LÓPEZ REYES, Néstor Daniel. 2010. La construcción del personaje trágico en "La cisma de Inglaterra" de Calderón de la Barca. México: UAM-I. Tesis de Maestría en Humanidades dirigida por el Dr. Marcelo Serafín González García.

LYOTARD, Jean Francois. 1996 (1986). La posmodernidad (explicada a los niños). Barcelona: Gedisa.

MACGOWAN, Kennet y William MELNITZ. 1994. Las edades de oro del teatro, México: FCE.

MALCUZYNSKI, M. Pierrete. 1996. "Bajtín, literatura comparada y sociocrítica feminista", en Poligrafías. Número 1, 1996. 23-43.

MATEOS CARRETERO, José Antonio. 2011 (consultado en.) "El teatro en Parla en el siglo XVII". Artículo en línea.

MARCUSE, Herbert. 1969. Ensayo sobre la liberación. México: Joaquín Mortiz.

MARGULES, Ludwik. 2004. Memorias. Conversaciones con Rodolfo Obregón. México: CONACULTA.

"No hay teatro sin conflicto", entrevistado en La Jornada Semanal. México, domingo 31 de mayo de 1987.

MARTÍNEZ LAÍNEZ, Fernando. 2005. "Entre la cruz y la espada", en Historia y vida. Agosto 2005. No. 449, año XXXVII. 
Marruecos. 1992. Barcelona: Escudo de Oro / Ministerio Marroquí de Turismo. (Colección Toda África, no. 1.) Guía turística.

MENDOZA, Héctor. 1999. Actuar o no (Actuar o no, "El Burlador" de Tirso, Creator Principium.) México: El Milagro / CNCA. 1992. Hamlet, por ejemplo. México: El Milagro.

MEYERHOLD, Vsevolod Emilievic. 1979 (1971.) Teoría teatral. Madrid: Fundamentos.

MOSTON, Doug. 1998. "Introduction", in Mr. William Shakespeares Comedies, Histories, \& Tragedies, A Facsimile of the First Folio, 1623. London: Routledge, iii.

MOSZYNSKA, Anna. 1990. Abstract Art. London: Thames and Hudson.

MÜLLER, Carol (Coord.) 2007 (2000.) El training del actor. México: UNAM / INBA. (Traducción de Le training de l'acteur, por Ma. Dolores Ponce G.)

NIETZSCHE, Frederick. 1992 (1871.) El origen de la tragedia. México: Espasa-Calpe.

NÚÑEZ, Nicolás. 1987. El teatro antropocósmico. México: SEP.

OEHRLEIN, Josef. 1993. El actor en el teatro español del Siglo de Oro. Madrid: Castalia.

ORTEGA Y GASSET, José. 1986 (1925). La deshumanización del arte e ideas sobre la novela. Velásquez. Goya. México: Porrúa.

PADRÓN MONTOYA, Carlos. "La puesta en escena a partir de un texto dramático", en Máscara, Cuaderno iberoamericano de reflexión sobre escenología. Núms. 7-8. Págs. 61-63.

PASCUAL LAVILLA, Isabel. 2003. "Claves para la técnica de la representación del actor en el Siglo de Oro. Don Gil de las calzas verdes: Una propuesta de lectura y puesta en escena", en Ars Theatrica-Estudios e Investigación.

PATÁN, Federico. 2001, Ángela o las arquitecturas abandonadas. México: Plaza \& Janés.

PAUL, Carlos, "Definen a Margules como "poeta de la complejidad", en La Jornada, viernes 6 de agosto de 2004. Cultura $4^{\mathrm{a}}$.

PAVIS, Patrice. 1994. El teatro y su recepción. Semiología, cruce de culturas y postmodernismo. La Habana: Casa de las Américas.

. 1983. Diccionario de Teatro: dramaturgia, estética, semiología, Barcelona: Paidós.

PUIG, Luisa. 1978. La estructura del relato y los conceptos de actante y función. México: UNAM.

PEÑA DEL SOL, Pedro. "La escenografía", en Máscara, Cuaderno iberoamericano de reflexión sobre escenología. Núms. 7-8. Págs. 78-82.

PÉREZ TAMAYO, Ruy. 2002 (1986.) Acerca de Minerva. (La ciencia para todos, 40.) México: FCE.

PIMENTEL, Luz Aurora. 1998. El relato en perspectiva. México: UNAM / Siglo XXI.

PIÑEIRO, Carlos. "Elementos básicos de dirección", en Máscara, Cuaderno iberoamericano de reflexión sobre escenología. Núms. 7-8. Págs. 31-50.

Poligrafías, Revista de literatura comparada. México: UNAM, núms. 1996, 1997 y 1998-2000.

PRADO ZAVALA, Jorge. 2003. "El drama como puesta en crisis de la historia", en Acta Poética. Número 24-1. Primavera de 2003. 185-203.

2003. Perspectivas sobre Samuel Beckett y Heiner Müller con base en la creatividad minimalista (Tesis de maestría.) México: UNAM.

2001. La textura poética del drama de Beckett. Ponencia presentada en el IV Congreso de Investigación Teatral de la Asociación Mexicana de Investigación Teatral (AMIT), celebrado en la Universidad de Sonora, del 2 al 4 de mayo de 2001. (Formó parte también de la tesis de maestría Perspectivas sobre Samuel Beckett y Heiner Müller con base en la creatividad minimalista [México: UNAM, 2003.])

QUIÑONES DE BENAVENTE. (s. XVII.) Loa con que empezó en la Corte Roque de Figueroa. Cit. en Oehrlein, 59.

RALL, Marlene y Dieter RALL (editores). 1996. Letras comunicantes, Estudios de literatura comparada. México: UNAM (Introducción de los editores).

RANGEL MORA, Zonia. 2011 (2008.) Teatro átmico, Sagrado sacerdocio. México: Verdesoma. REINHARDT, Adolph. 1975. Art as art: The selected writings of Ad Reinhardt. NY: Viking. 
REINHARDT, Ad. 1957. "Twelve rules for a new academy", en revista Art News. NY: Mayo de 1957. (Citado en Reinhardt 1975: 203-207.)

RIVERA, Virgilio Ariel. 1993 (1989.) La composición dramática. México: Gaceta.

RODRÍGUEZ, Benjamín. Entrevistado por Rosario Pinelo: "Benjamín Rodríguez: Barroco", en Tiempo Libre. Del 31 de marzo al 6 de abril de 2011. XXXI. 1612. 41.

RODRÍGUEZ CUADROS, Evangelina. 1998. La técnica del actor español en el Barroco. Madrid: Castalia.

RODRÍGUEZ SÁNCHEZ DE LEÓN, María José. 2000. La crítica ante el teatro barroco español (Siglos XVII-XIX). Salamanca: Almar / Colegio de España.

ROJAS VILLANDRANDO, Agustín de. 1603. El viaje entretenido. Madrid: Imprenta Real. Edición digital de la Biblioteca Virtual Miguel de Cervantes.

ROMÁN CALVO, Norma. 2007. El modelo actancial y su aplicación. México: UNAM / Pax. . 2001. Para leer un texto dramático. Del texto a la puesta en escena. México: UNAM / Árbol.

ROUGER, Gustave. 1988. Las aventuras de 'Antar. BCN: Hesperus / José Olañeta.

ROZAS, Juan Manuel. Sobre la técnica del actor barroco. (Anotada por Jesús Cañas Murillo.) Biblioteca Virtual Miguel de Cervantes. Artículo en línea.

SÁNCHEZ VÁSQUEZ, Adolfo (comp.) 1978. Textos de estética y teoría del arte. México: UNAM.

SANCHIS SINISTERRA, José. 2008 (1980.) Ñaque o De piojos y actores. México: CONACULTA. Recreación de El viaje entretenido, de Agustín de Rojas Villandrando.

1996. Apuntes del curso "Nuevas tendencias de la producción y creación teatrales en el área de la dramaturgia". Barcelona: Sala Beckett (inéditos).

1994. "Por una teatralidad menor" en Salas alternativas: un futuro posible, Lleida: Fira de Teatre de Tárrega / Institut d' Etudis Ilerdencs. 25-31.

SANZ AYÁN, Carmen. 1999. "Felipe II y los orígenes del teatro barroco", en Cuadernos de historia moderna. No. 23, monográfico V, 47-78.

SARTRE, Jean Paul. 1980 (1949.) Literature and Existentialism (What is literature?) New Jersey: Citadel.

SCHNEIDER, Norbert. 1999. Naturaleza muerta. Colonia (Köln.) Taschen.

SCOLNICOV, Hanna y Peter HOLLAND (comps.) 1991 (1989). La obra de teatro fuera de contexto, México: Siglo XXI.

SÉNECA. (Siglo I.) Cartas a Lucilio.

SERRANO, Raúl. 1996. Tesis sobre Stanislavski en la educación del actor. México: Escenología.

SHAKESPEARE, William. 1601. Twelfth Night.

1600. Hamlet.

1599. Henry $V$.

.1595-96. A Midsummer Night's Dream.

STANISLAVSKI, Constantin. 1998 (1933 y 1952). El arte del actor (Principios técnicos para su formación), por Richard Boleslavski y Michael Chejov; selección y notas de Edgar Ceballos. México: Escenología.

1994 (1947.) Ética y disciplina. Método de acciones físicas (Propedéutica del actor). México: Escenología. Selección y notas de Edgar Ceballos. 1992. Creación de un personaje. México: Diana.

1990 (1963.) Manual del actor. México: Diana.

1990 (1953.) Un actor se prepara. México: Diana.

STEINER, George. 1973 (1971). Extraterritorial: Ensayos sobre la literatura y la revolución lingüística. Barcelona: Barral.

. La muerte de la tragedia.

SULLIVAN, Henry W. 2000. "Shakespeare with Calderon: Hamlet, Prince of Denmark \& Sigismund, Prince of Poland", en Gestos: Teoría y Práctica del Teatro Hispánico. Nov. 2000; 15 (30): 51-69. 
TALHOFFER, Hans. 1459. Alte Armatur und Ringkunst. Manual de combate y esgrima, edición facsimilar en línea.

The Catholic Encyclopaedia. 2010 (1913.) Online edition.

THENÓN, Luis. 2002. "La formación del actor-investigador", en Investigación teatral. Revista de la Asociación Mexicana de Investigación Teatral (AMIT.) Núm. 2. Julio-Dic. de 2002. 1125.

TORZENKA, Marzena. 1994. "La última entrevista con Ryszard Cieslak", en Máscara. Año 4, Número 16. Enero de 1994. 25-27. (Traducción de Margherita Pavia a "Correr para tocar el horizonte", en el periódico polaco-americano Nowy Dziennik. 2 de mayo de 1990.)

UBERSFELD, Anne. 1981. L'école du spectateur. Paris: Les editions sociales. . Semiótica teatral. Madrid: Cátedra / Universidad de Murcia.

USCATESCU, George. 1968. Teatro occidental contemporáneo, Madrid: Guadarrama.

VALENCY, Maurice. 1980. The end of the world, An introduction to contemporary drama, NY and Oxford: OUP.

VARGAS, Alfredo, "Los Justos", en Paso de Gato, año 2, número 7, marzo-abril de 2003, 51.

Varios: Carlos Solórzano, Gabriel Weisz, et al. 1997. Métodos y técnicas de investigación teatral. México: UNAM / Escenología.

VELÁSQUEZ DE LEÓN, Mauricio. 2000. “Ante la muerte del cine de autor, ¿Dogma?”, en diario Reforma. México: Viernes 14 de Julio. Sección Cultural, p. 5.

VILLALBA GARCÍA, María de los Ángeles. 1989. 'La gestualidad escénica en la comedia de capa y espada', Revista de Literatura, $\mathrm{n}^{\circ}$ LI.101.

VILLAREAL DÍAZ, Alberto. "Del ensayo como ensayo", en Paso de gato. México: Año 5, número 26, julio-septiembre de 2006.

VILLORO, Luis. 2006. "La vivencia personal, raíz de la reflexión filosófica”, entrevista por: Carlos Oliva Mendoza, en Metate, periódico de la Facultad de filosofía y letras. Año I, núm. 8. Mayo, 2006: 1 y 5.

VINCENT, Nidia. "El cuerpo que ríe: Dinámicas de la comicidad teatral", en Acta Poética. (Revista del Instituto de Investigaciones Filológicas de la UNAM.) Núm. 24-1, primavera de 2003. 127-142.

VINSAUF, Geoffroi de. 2000 (Fines del Siglo XII.) La poética nueva. México: UNAM. Presentación y traducción de Carolina Ponce.

WEISZ CARRINGTON, Gabriel. "Acústica animada”, en Máscara, Cuaderno iberoamericano de reflexión sobre escenología. Núms. 7-8. Págs. 98-104.

1998. Dioses de la peste. México: UNAM y Siglo XXI.

1999. Notas del curso monográfico de teoría literaria Historias corporales II, textos chamánicos. México: Facultad de Filosofía y Letras de la UNAM.

. 1996. "Personificaciones somáticas", en Poligrafías. Número 1, 1996. 65-81.

WILSHIRE, Bruce. 1982. Role Playing and Identity. The Limits of Theatre as Metaphor. Indiana: Indiana University Press.

WORTHEN, William B. 1997. Shakespeare and the Authority of Performance. Cambridge: Cambridge University Press (CUP).

2003. Shakespeare and the Force of Modern Performance. Cambridge: CUP.

WRIGTH, Edgard. 1988. Para comprender el teatro actual, México: FCE.

ZAHAREAS, Anthony N. 1994. Cervantes, Shakespeare and Calderon: Theater and Society. Louisiana: Louisiana State UP.

ZAVALA, Lauro. 1998. La precisión de la incertidumbre: posmodernidad, vida cotidiana y escritura. México: UAEM.

(compilador) 2000. Relatos vertiginosos, Antología de cuentos mínimos. México: Alfaguara. 
Fuentes específicas de y sobre Calderón

AMEZCUA, José. 1991. Lectura ideológica de Calderón, El médico de su honra. México: UAM / UNAM.

ARELLANO, Ignacio y Enrica CANCELLIERE (edits.) 2006. La dramaturgia de Calderón, técnicas y estructuras (Homenaje a Jesús Sepúlveda). Madrid: Iberoamericana/Universidad de Navarra.

CALDERÓN DE LA BARCA, Pedro. Andrómeda y Perseo. Biblioteca Virtual Miguel de Cervantes.

. El gran teatro del mundo.

1988 (1637.) El mágico prodigioso. México: Rei / Cátedra.

1979. El médico de su honra. Madrid: Espasa-Calpe.

2010 (consultada en...) El príncipe constante. Madrid: Biblioteca Virtual Miguel de Cervantes.

Edición digital a partir del Ms. 15.159 de la Biblioteca Nacional de España, y cotejada con

la edición crítica de Fernando Cantalapiedra y Alfredo Rodríguez López-Vázquez, Madrid, Cátedra, 1996.

1977 (1636.) El príncipe constante. Panamá: Empresa Latinoamericana de Comercio Exterior.

2009 (1640.) Comedia famosa del príncipe constante. Edición facsimilar digital de la Biblioteca Virtual Cervantes (Alicante) y la Biblioteca Nacional de España (Madrid) de Primera parte de las comedias de Pedro Calderón de la Barca. Madrid: Viuda de Juan Sánchez, a costa de Gabriel de León, 1640.

. 1636. El príncipe constante. (Edición príncipe.) Madrid: José Calderón (hermano de Pedro Calderón.) Acervo de la Biblioteca Nacional (España.)

. 2003. (1629.) El príncipe constante. Manuscrito 15.159 de la Biblioteca Nacional de España.

Alicante. http://www.cervantesvirtual.com/FichaObra.html?Ref=9544\&portal=42 .

. 1979. La devoción de la cruz. Madrid: Espasa-Calpe.

. 1986. La vida es sueño. Barcelona: La montaña mágica.

DUQUE, Pedro J. 1983. "Calderón-Shakespeare: Algunas similitudes y diferencias", en Actas del Congreso internacional sobre Calderón y el teatro español del Siglo de Oro. Madrid: Consejo Superior de Investigaciones Científicas. 1277-1288.

DURÁN, Manuel y Roberto GONZÁLEZ ECHEVARRÍA (editores). 1976. Calderón y la crítica: Historia y antología. Madrid: Gredos. 2 tomos.

LAUER, Robert. 2009 (2008.) "Bibliografía de El Príncipe Constante", en http://faculty_staff.ou.edu/L/A-Robert.R.Lauer_1/BIBLIOGRAFIAINFOASISTIDA.

Consultada en octubre de 2009.

PARKER, Alexander. 1976 (1962). "Hacia una definición de la tragedia calderoniana", en DURÁN, Manuel y Roberto GONZÁLEZ ECHEVARRÍA (editores). 1976. 359-387.

PRADO ZAVALA, Jorge. 2012. El príncipe constante o "La tragedia perdida del Infante Santo Fernando de Portugal", de don Pedro Calderón de la Barca, tal y como habría sido interpretada en bululú por don Antonio García de Prado en la ermita de Sant Jordi, una legua al norte de Barcelona, la madrugada del 23 de abril de 1629 como penitencia para ingresar a la Cofradía de Actores de Nuestra Señora de la Novena de Madrid. México: Laboratorio de Teatro Libertad. Adaptación libre (en versión de facsímil apócrifo) de La comedia famosa del príncipe constante de Pedro Calderón de la Barca, concepción minimalista para una puesta en escena neobarroca y notas.

RESINA RODRÍGUES, María Idalina. 2006. "Hacia El Príncipe Constante", en ARELLANO, Ignacio y Enrica CANCELLIERE (edits). 465-480.

RODRÍGUEZ CUADROS, Evangelina. 2010 (consultada en.) Un discreto a voces: Entrevista (imaginada) con Don Pedro Calderón de la Barca. Artículo en línea.

RUIZ RAMÓN, Francisco. 1983. Historia del teatro español. (Desde sus orígenes hasta 1900), $5^{\text {a }}$ ed. Madrid: Cátedra.

, 2000. Calderón nuestro contemporáneo. Madrid: Castalia. 
, 1984. Calderón y la tragedia. Madrid: Alhambra.

SÉNECA, Lucio Anneo. 1999. (Siglo I.) "Cartas a Lucilio", en Literatura epistolar, varios autores. México: CONACULTA / Océano.

SERRANO DEZA, Ricardo. (2011, consultado en.) "El príncipe constante o la locura del despojamiento." Quebec: Université du Québec à Trois-Rivières. Artículo en línea.

SIRERA TURÓ, Josep Lluis. 1982. El teatro en el siglo XVII: El ciclo de Calderón. Madrid: Playor.

SPITZER, Leo. 1976 (1960). “El personaje de Fénix en El Príncipe Constante, de Calderón”, en DURÁN, Manuel y Roberto GONZÁLEZ ECHEVARRÍA (edits). 1976. 598-628.

VALBUENA BRIONES, Ángel. 1965. Perspectiva crítica de los dramas de Calderón. Madrid: Rialp.

VALLEJO, Javier. 2006. “El ‘Calderón’ de Grotowski”, en El País. 11 de marzo de 2006. Sección Cultural.

Vídeo

El príncipe constante o "La tragedia perdida del Infante Santo Fernando de Portugal", de don Pedro Calderón de la Barca, tal y como habría sido interpretada en bululú por don Antonio García de Prado en la ermita de Sant Jordi, una legua al norte de Barcelona, la madrugada del 23 de abril de 1629 como penitencia para ingresar a la Cofradía de Actores de Nuestra Señora de la Novena de Madrid. México: Laboratorio de Teatro Libertad, 2011. Un espectáculo neobarroco de: Jorge Prado Zavala. Filmado en la Casa de Cultura Las Jarillas por Miguel Ángel Gorostieta Moreno, Blue Sound Studios.

\section{Iconografía (Pintura, escultura y arquitectura)}

BERNINI, Gianlorenzo. (1645-1652.) Éxtasis de Santa Teresa. Capilla de Sta. María de la Victoria, Roma.

1623. David. Galería Borghese, Roma.

CARAVAGGIO. (Siglo XVII.) Flagelación de Cristo. Bridgeman Art Library, London / NY.

COELLO, Claudio. (s/f). El Rey Carlos II de España recibe la Santa Comunión. Monasterio de El Escorial, España.

Colegial del Divino Salvador. Sevilla, España. Foto de José C.

CHURRIGUERA, José Benito. (1693-1700.) Retablo. Iglesia de San Esteban en Salamanca, España.

DE HEEM, Jan. (S. XVII.) Fruta y flores. Cheltenham Gallery, Inglaterra.

Fray Felipe de Jesús. 1650. Catedral Metropolitana de México.

GENTILESCHI, Artemisa. 1620. Judit asesinando a Holofernes. Bridgeman Art Library, London / NY.

GONÇALVES, Nuno. (S. XV.) Painel do Infante Santo, en el Painel de San Vicente de Fora. Museu Nacional de Arte Antiga de Lisboa.

Imagen de una representación teatral en Austria. Siglo XVII. Museo de Viena, Austria.

KANDINSKY, Wassily. 1912. Improvisación 28, segunda versión. ADAGP, París.

Las Quinas. Escudo de Armas de Portugal, de la Casa de Avis y del Infante Fernando.

NEUMANN, Balthasar. (S. XVIII.) Residenz in Würzburg. Alemania.

$O$ Infante Santo cautivo. (s/f). Retablo en la Capilla Real en el Monasterio de Batalha, Portugal.

PEREDA, Antonio de. (circa 1640-1650?) Alegoría de la vanidad de la vida (Vanitas). Museo Provincial de Zaragoza (España) y Kunsthistorishes Museum (Viena, Austria.) 139.5 x 174 $\mathrm{cm}$.

POLLOCK, Jackson. 1948. Black and white. Pollock-Krasner Foundation \& Artists Rights Society (ARS), NY.

POUSSIN, Nicolas. 1648. Paisaje con el funeral de Fosión. Louvre, París. 
REINHARDT, Ad. 1964. Abstract Painting. Marlborough Gallery, NY. (Reproducida a partir de Reinhardt 1975: 41.)

REMBRANDT van RIJN. 1659. Moisés rompe los diez mandamientos. Dahlem Staatliche Gemaldegalerie, Berlín.

. 1642. La guardia nocturna o La compañía de tiradores del Capitán Frans Banning Cocq. Bridgeman Art Library, London / NY.

Retablo. (Ss. XVII y XVIII.) Monasterio de San Francisco en Salvador, Bahía, Brasil.

RODRÍGUEZ, Ramón. Cortes transversales del Corral del Príncipe [escenario y entrada]. Madrid: Universitat de Valencia.

RUBENS, Peter Paul. 1635. El juicio de Paris. Bridgeman Art Library, London / NY:

1620. Cristo en la Cruz. Koninklijk Museum voor Schone Kunsten, Antwerp, Bélgica.

Salón de recepción del Palacio de Versalles, Francia. (s/f).

SALVI, Nicola. (Siglo XVIII.) Fuente de la Trevi. Roma.

Sant Jordi y el Dragón. (Medieval, s/f). Códice griego ortodoxo.

STELLA, Frank. 1973. Rozdol II. Frank Stella \& Artists Rights Society (ARS). Seattle Art Museum, Seattle.

VELÁZQUEZ, Diego Rodríguez de Silva y. 1656. Las Meninas. Museo del Prado, Madrid.

1635. Retrato del actor Pablo de Valladolid. Museo del prado, Madrid.

1619-1620. Aguador de Sevilla. Museo del Prado. Madrid.

WARHOL, Andy. 1962. Campbell's Soup Can. Andy Warhol Foundation for the Visual Arts \& Artists Rights Society (ARS), NY.

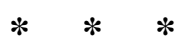

\section{OTRAS FUENTES}

\section{Bibliohemerografía de Robert Lauer sobre El príncipe constante de Calderón}

Alba Buffill, Elio. 2003. Estudios sobre letras hispánicas. Miami, FL: Universal.

Alba Buffill, Elio. 1981. «Las ideas centrales en El príncipe constante de Calderón de la Barca». Gutiérrez de la Solana, Alberto (ed.); Alba Buffill, Elio (ed.) Festschrift José Cid Perez. New York: Senda Nueva de Eds. 167-73.

Alcalá Zamora, José. 1998. «Los mares portugueses en Calderón». Cuenca, Luis Alberto de (ed.) La poesía y el mar / A Poesia e a Mar. Madrid, Spain: Visor. 15-32.

Brecht, Stefan. 1997. "The Laboratory Theatre in New York, 1969: A Set of Critiques.” Wolford, Lisa (ed.); Schechner, Richard (ed.) The Grotowski Sourcebook. Worlds of Performance. Londres: Routledge. 118-33.

Cabañas, Pablo. 1980. «Los sonetos calderonianos de El príncipe constante». Gordon, Alan M. (ed.); Rugg, Evelyn (ed.); Lapesa, Rafael (foreword). Actas del Sexto Congreso Internacional de Hispanistas celebrado en Toronto del 22 al 26 agosto de 1977. Toronto: Dept. of Sp. \& Port., Univ. of Toronto, 132-35.

Campbell, Ysla. 2004. "Presencia de Justo Lipsio en El príncipe constante." Lerner, Isaías (ed.); Nival, Robert (ed.); Alonso, Alejandro (ed.). Actas del XIV Congreso de la Asociación Internacional de Hispanistas, II: Literatura española, siglos XVI y XVII. Hispanic Monographs. Newark, DE: Juan de la Cuesta, 67-72.

Cancelliere, Enrica. (2003.) «Dos tipos de locura: La rebelión de Segismundo y la obediencia de don Fernando». Criticón 87-89: 129-41.

Cancelliere, Enrica. 1994. «Estrategias simbólicas e icónicas del Thanatos en El príncipe constante de Calderón». Villegas, Juan (ed.) Actas Irvine 92, Asociacion Internacional de Hispanistas, III: Encuentros y desencuentros de culturas desde la edad media al siglo XVIII. Irvine: Univ. of California, III: 177-89.

Cantalapiedra, Fernando (ed.) \& Rodríguez Lopez-Vázquez, Alfredo (ed.) 1996. El príncipe constante. Letras Hispánicas 415. Madrid: Cátedra.

Cardona, Ángeles. 1992. «Más sobre la influencia de Calderón en el romanticismo alemán: El caso de Zacharias Werner y su teatro». Vilanova, Antonio (ed.); Bricall, Josep Ma. (fwd.); Rivers, Elías L. (pref.) Actas del X Congreso de la Asociación de Hispanistas, I-IV. Barcelona: Promociones y Pubs. Universitarias, I: 813-25.

Dunn, Peter N. 1973. "El príncipe constante: A Theatre of the World". Jones, R. O. Studies in Spanish Literature of the Golden Age Presented to Edward M. Wilson. London: Tamesis, 83-101.

Finch, Mary F. (1971) “'On Being and Essence' and 'El príncipe constante"”. Hispanófila 43: 17-24.

Fischer, Susan L. 1983. «Aspectos psicológicos de la clarividencia y del martirio en El príncipe constante». González, Ángel (ed.); Holzapfel, Tamara (ed.); Rodríguez, Alfred (ed.); Nason, Marshall R. (biog.); Brooks, Mary Elizabeth (biog.) Estudios sobre el Siglo de Oro en homenaje a Raymond R. MacCurdy. Albuquerque; Madrid: Univ. of New Mexico, Dept. of Mod. \& Classical Langs.; Cátedra, 135-49.

Fox, Dian. (1980.) “A Further Source of Calderón's El príncipe constante.” Journal of Hispanic Philology 4.2: 157-66.

García Gómez, Ángel María. (2000.) «Tiempo, fortuna y constancia: Trama y entramado en El príncipe constante de Calderón». Bulletin of Hispanic Studies (Glasgow) 77.1: 111-32. 
Gascón Vera, Elena. 1983. «La voluntad y el deseo en El príncipe constante». García Lorenzo, Luciano (ed.) Calderón: Actas del Congreso internacional sobre Calderón y el teatro español del Siglo de Oro. Madrid: Consejo Superior de Investigaciones Científicas, 451-59.

Gutiérrez Araus, María Luz. 1983. «Funcionamiento del hipérbaton en El príncipe constante». García Lorenzo, Luciano (ed.) Calderón: Actas del Congreso internacional sobre Calderón y el teatro español del Siglo de Oro. Madrid: Consejo Superior de Investigaciones Científicas, 1109-24.

Halkhoree, Premraj R. K.; Varey, John. 1979. «Sobre el tema de la cárcel en El príncipe constante». Flasche, Hans (ed.); Körner, KarlHermann (ed.) Hacia Calderón: cuarto Coloquio Anglogermano, Wolfenbüttel, 1975: Coloquio Anglogermano (4th: 1975: Wolfenbüttel. Germany). Hamburger romanistische Studien. B. Ibero-Amerikanische Reihe Bd. 42; Calderoniana Bd. 13. Berlín y Nueva York: Walter de Gruyter, 30-40.

Hernández Nieto, Héctor. 1990. «'Yo lo sé, porque en el mar': Apariencia, desengaño y certeza en el parlamento de Muley». García de la Concha, Víctor (ed.); Canavaggio, Jean (ed.); Berchem, Theo (ed.); Lobato, María Luisa (ed.) Teatro del Siglo de Oro: Homenaje a Alberto Navarro González. Kassel: Reichenberger, 285-96.

Hernández Nieto, Héctor. 1989. «El príncipe constante y Edipo». Laurenti, Joseph L. (ed. \& bibliog.); Williamsen, Vern G. (ed. \& introd.). Varia hispanica: Homenaje a Alberto Porqueras Mayo. Kassel: Reichenberger, 61-79.

Ladra, David. (2000) «A propósito de una representación de El príncipe constante». Primer Acto: Cuadernos de Investigación Teatral 286: $107-16$

Larson, Donald R. (2004) "Embodying Transcendence: Grotowski's The Constant Prince." Comedia Performance: Journal of the Association for Hispanic Classical Theater 1.1: 9-45.

Loftis, John. (1970) "El príncipe constante and The Indian Emperour: A Reconsideration." Modern Language Review 65: 761-67.

Ludlam, Charles. 1997. "Let Grotowski Sacrifice Masculinity Too." Wolford, Lisa (ed.); Schechner, Richard (ed.) The Grotowski Sourcebook. Worlds of Performance. Londres: Routledge, 141-43.

Lumsden-Kouvel, Audrey. (2000) “A Counter-Reformation Hero: The Saint and Martyr in Calderon's El príncipe constante.” Bulletin of Hispanic Studies (Glasgow) 77.1: 101-10.

Lumsden Kouvel, Audrey. 1983. «El príncipe constante: Drama de la contrarreforma: La tragedia de un santo mártir». García Lorenzo, Luciano (ed.) Calderón: Actas del Congreso internacional sobre Calderón y el teatro español del Siglo de Oro. Madrid: Consejo Superior de Investigaciones Científicas, 495-501.

Maestro, Jesús G. 2003. «Los límites de una interpretación trágica y contemporánea del teatro calderoniano: El_príncipe constante». Tietz, Manfred (ed.). Teatro calderoniano sobre el tablado: Calderón y su puesta en escena a través de los siglos. XIII Coloquio Anglogermano sobre Calderón, Florencia, 10-14 de julio de 2002. Con un CD-ROM con los materiales audiovisuales y los índices de los artículos publicados en las actas de los Coloquios Anglogermanos sobre Calderón (Exeter 1969 - Florencia 2002). Archivum Calderonianum 10. Stuttgart: Franz Steiner, 285-327.

Maestro, Jesús, 2004. El mito de la interpretación literaria: Rojas, Cervantes y Calderón: La ética de la literatura y sus dogmas contemporáneos. Madrid: Iberoamericana; Frankfurt: Vervuert.

Norval, Maria. (1973) "Another Look at Calderón's El príncipe constante." Bulletin of the Comediantes 25: 18-28.

O'Reilly, Terence. (1980) "The Sonnets of Fernando and Fénix in Calderón's El príncipe constante". Forum for Modern Language Studies 16: 350-57.

Orduna, Germán. 1991. «Algo más sobre la función dramática de los sonetos de 'El príncipe constante'». Körner, Karl-Hermann (ed.); Zimmermann, Günther (ed.); Lapesa Melgar, Rafael (introd.) Homenaje a Hans Flasche: Festschrift zum 80. Geburtstag am 25. November 1991. Stuttgart: Steiner, 162-73.

Ortigoza Vieyra, Carlos, 1957. Los móviles de la comedia, primera parte: El príncipe constante de Calderón de la Barca, segunda parte: Investigación y estudio crítico, los móviles del protagonista. México: Robredo.

Ouaknine, Serge; Jacquot, Jean (introd.) 1970. «Théâtre laboratoire de Wroclaw: Le Prince constant, scenario et mise en scene par Jerzy Grotowsky: Étude et reconstitution du deroulement du spectacle». Jacquot, Jean (ed.) Les Voies de la creation theatrale, I. Paris: CNRS, 33-129.

Parker, Alexander A. 1973. "Christian Values and Drama: 'El principe constante'." Körner, Karl-Hermann; Rühl, Klaus. Studia Iberica: Festschrift für Hans Flasche. Bern: Francke, 441-57.

Parr, James A. 1986. "El príncipe constante and the Issue of Christian Tragedy." Fiore, Robert (ed.); Hesse, Everett W. (ed.); Keller, John E. (ed.); Madrigal, José A. (ed.) Studies in Honor of William C. McCrary. Lincoln: Univ. of Nebraska, Soc. of Sp. \& Sp. Amer. Studies, 165-75.

Paterson, Alan K. G. 1989. «Justo Lipsio en el teatro de Calderón; Ensayos dedicados a John E. Varey». Ruano de la Haza, José M. (ed.) El mundo del teatro español en su Siglo de Oro. Ottawa: Dovehouse, 275-91.

Paterson, Alan K. G. 1976. «El local no determinado en El príncipe constante». Flasche, Hans (ed.) Hacia Calderón: Coloquio Anglogermano (3rd: 1973: London). Tercer Coloquio Anglogermano, Londres 1973. Hamburger romanistische Studien: B. Ibero-amerikanische Reihe, Bd. 39; Calderoniana, Bd. 10. Berlín y Nueva York: Walter de Gruyter, 171-84.

Porqueras Mayo, Alberto. 1994. «Impacto de El príncipe constante en la crítica hispanística. (1972-1992)». Flasche, Hans (ed.); Dirscherl, Klaus (ed.); Jakob, Thomas (índice); Neumeister, Sebastian (índice). Hacia Calderón: Décimo Coloquio Anglogermano, Passau 1993. Stuttgart: Steiner, 213-22.

Porqueras Mayo, Alberto. 1983. «En torno al manuscrito del siglo XVII de El príncipe constante». García Lorenzo, Luciano (ed.) Calderón: Actas del Congreso internacional sobre Calderón y el teatro español del Siglo de Oro. Madrid: Consejo Superior de Investigaciones Científicas, 235-48.

Porqueras Mayo, Alberto. 1982. «Función y significado de Muley en El príncipe constante». McGaha, Michael D. (ed. \& pref.) Approaches to the Theater of Calderón. Washington, DC: UP of America, 157-73.

Profeti, Maria Grazia. (1987.) "Paratesto e contesto: 'Il principe costante' di Alberto Arbasino." Quaderni di Lingue e Letterature [Verona] 12: 153-58.

Reichenberger, Arnold G. (1960.) “Calderón's El príncipe constante, a Tragedy?” Modern Language Notes 75.8: 668-70.

Rivers, Elias L. (1969.) "Fénix's Sonnet in Calderón's Príncipe constante." Hispanic Review 37.4: 452-58.

Rodrigues, Maria Idalina Resina. «Hacia El príncipe constante». Arellano, Ignacio (ed.); Cancelliere, Enrica (ed.) La dramaturgia de Calderón: Técnicas y estructuras (Homenaje a Jesús Sepúlveda). Biblioteca Áurea Hispánica 22. Madrid: Iberoamericana; Frankfurt: Vervuert, 2006. 465-80. 
Sage, Jack. 1973. “The Constant Phoenix: Text and Performance of Calderón's 'El príncipe constante'.” Körner, Karl-Hermann; Ruhl, Klaus. Studia Iberica: Festschrift für Hans Flasche. Bern: Francke, 561-74.

Salley, W. C. (1932.) “A Possible Influence of the Abencerraje Story on Calderón's El Príncipe Constante.” Romanic Review 23: 331-33.

Sánchez Jiménez, Antonio. (2005.) «Un misterio virgiliano en El príncipe constante, de Pedro Calderón de la Barca». Bulletin of the Comediantes 57.2: 425-39.

Shao, Yun. (2006.) "Painting and Perspective in Calderon's El príncipe constante." Bulletin of the Comediantes 58.2: 399-420.

Shergold, N. D.; Ure, Peter. (1966.) "Dryden and Calderón: A New Spanish Source for The Indian Emperour." Modern Language Review 61: 369-83.

Sloane, Robert. (1970.) “Action and Role in El príncipe constante." MLN 85: 167-83.

Stroud, Matthew D. 2006. "Another Look at Calderón's El príncipe constante as Tragedy.” Simerka, Barbara (ed.); Williamsen, Amy R. (ed.); Polchow, Shannon (ed.) Critical Reflections: Essays on Golden Age Spanish Literature in Honor of James A. Parr. Lewisburg, PA: Bucknell University Press, 17-30.

Stroud, Matthew D. 2007. Plot Twists and Critical Turns: Queer Approaches to Early Modern Spanish Theater. Lewisburg, PA: Bucknell University Press.

Sullivan, Henry Wells. 1982. «Un manuscrito desconocido de la refundición por Goethe del Standhafte Prinz (Calderón/A. G. Schlegel)». Flasche, Hans (ed.); Pring-Mill, Robert D. F. (ed.) Hacia Calderón. Quinto Coloquio Anglogermano, Oxford 1978. Archivum Calderonianum 1. Wiesbaden: Franz Steiner, 74-82.

Truman, R. W. (1964.) “The Theme of Justice in Calderón's El príncipe constante.” The Modern Language Review 59: 43-52.

Varey, John E.; Halkhoree, Premraj R. K. 1979. «Sobre el tema de la cárcel en El príncipe constante». Flasche, Hans (ed.); Körner, Karl-Hermann (ed.) Hacia Calderón: cuarto Coloquio Anglogermano, Wolfenbüttel, 1975: Coloquio Anglogermano (4th: 1975: Wolfenbüttel. Germany). Hamburger romanistische Studien. B. Ibero-Amerikanische Reihe Bd. 42; Calderoniana Bd. 13. Berlín y Nueva York: Walter de Gruyter, 30-40.

Vincent, Karen Dahlquist. 1977. "A Critique of Concepts of Tragedy and El príncipe constante as Christian Tragedy." Dissertation Abstracts International, Ann Arbor, MI, 37, 5876A 77A.

Voros, Sharon Dahlgren. 1994. "The Feminine Adjuvant: Toward a Semiotics of Calderonian Plot Dynamics." Ganelin, Charles (ed. \& introd.); Mancing, Howard (ed. \& introd.) The Golden Age Comedia: Text, Theory, and Performance. West Lafayette, IN: Purdue UP, 324-41.

Whitby, William M. (1956.) “Calderón's El Príncipe Constante: Fenix's Role in the Ransom of Fernando's Body.” Bulletin of the Comediantes 8.1: 1-4.

Whitby, William M. 1982. "Calderón's El príncipe constante: Structure and Ending." McGaha, Michael D. (ed. \& pref.). Approaches to the Theater of Calderón. Washington, DC: UP of America, 143-55.

Wilson, E. M. (1961.) “An Early Rehash of Calderón's El príncipe constante.” Modern Language Notes 76.8: 785-94.

\section{Bibliohemerografía de Ricardo Serrano Deza sobre El príncipe constante de Calderón}

CALDERÓN DE LA BARCA, Pedro [2003]: El príncipe constante y esclavo por su patria: gran comedia, Biblioteca Nacional de España, manuscrito número Ms. 15.159, publicado en facsímile por Biblioteca Virtual Miguel de Cervantes, Alicante, http://www.cervantesvirtual.com/FichaObra.html?Ref=9544\&portal=42 .

CALDERÓN DE LA BARCA, Pedro [1636]: Primera parte de comedias de don Pedro Calderón de la Barca (recogidas por don Joseph Calderón de la Barca su hermano), por María de Quiñones (a costa de Pedro Coello y de Manuel López), Madrid.

CALDERÓN DE LA BARCA, Pedro [1996]: El príncipe constante (basada en el manuscrito Ms.15.159 de la Biblioteca Nacional de España), Cantalapiedra, Fernando y Rodríguez López-Vázquez, Alfredo Ed., Cátedra, Madrid.

LADRA, David [2000]: “A propósito de una representación de El príncipe constante”, en Primer Acto, 286, pp. 107-116.

OUAKNINE, Serge [1968]: “Alrededor de El príncipe constante", en Primer Acto, 95, pp. 28-43.

PORQUERAS MAYO, Alberto [1977]: "En torno al Príncipe constante: La relación Fénix-Fernando", en Chevalier, Maxime; Lopez, Francois; Perez, Joseph; Salomon, Noel Ed., Actas del Quinto Congreso Internacional de Hispanistas, PU de Bordeaux, Bordeaux, pp. 687-698.

SERRANO DEZA, Ricardo [1998a]: "Segmentación, estructura comunicacional y cambio de forma métrica: hacia el establecimiento de una hipótesis verificable", en García de Enterría, M. C. ed., Actas del IV Congreso de la AISO (Alcalá, 1996), Universidad de Alcalá, Alcalá de Henares, pp. 1.529-1.536.

SERRANO DEZA, Ricardo [1998b]: "Anticipación, suplantación, repetición: tres claves de lectura para El médico de su honra de Calderón". Criticón, num. 73, pp. 121-142.

SERRANO DEZA, Ricardo [1999]: "Despliegue y repliegue de la acción en el teatro de Cervantes: análisis secuencial de La Numancia y de las comedias", en Poupeney-Hart, C., Hermenegildo, A., y Oliva, C., ed., Cervantes y la puesta en escena de la sociedad de su tiempo, Universidad de Murcia, Murcia, pp. 93-109.

SERRANO DEZA, Ricardo [2000]: "Movimientos de escena y 'movimientos' del espectador en un corpus de autos calderonianos", en Sevilla, F. y C. Alvar, C. ed., Actas del XIII Congreso de la Asociación Internacional de Hispanistas (Madrid 1998), Castalia, vol. I, Madrid, pp. 729-739.

SPITZER, Leo [1965]: “The Figure of Fénix in Calderón's El príncipe constante”, en Wardropper, B. W. ed., Critical Essays on the Theatre of Calderón, New York U. P., New York, pp. 137-160 (es traducción de un original alemán, publicado en 1960 en Romanistisches Jahrbuch, X, 668-670). 